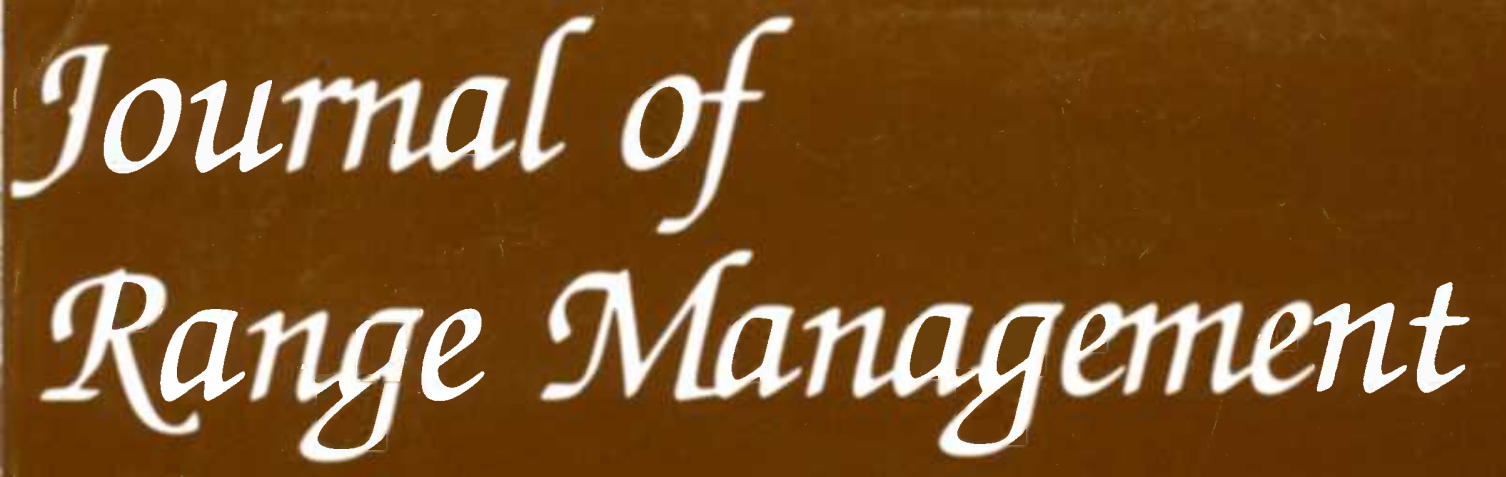

\section{TABLE OF CONTENTS: VOL. 56, NO. 3, May 2003}

FEATURE ARTICLE

206 Distribution of Russian knapweed in Colorado: Climate and environmental factors by Sarah C. Goslee, K. George Beck and Debra P.C. Peters

\section{Grazing Management}

213 Fall grazing affects big game forage on rough fescue grasslands by Jeffrey J. Short and James E. Knight

218 Economic and environmental impacts of pasture nutrient management by Edward Osei, Philip W. Gassman, Larry M. Hauck, Susan Neitsch, Ron D. Jones, Jan McNitt, and Heather Jones

Hydrology

227 Runoff and soil loss in undisturbed and roller-seeded shrublands of semiarid Argentina by Manuel O. Aguilera, Diego F. Steinaker, and Manuel R. Demaria

234 Evaluation of USLE and RUSLE estimated soil loss on rangeland by Kenneth E. Spaeth Jr., Frederick B. Pierson Jr., Mark A. Weltz, and Wilbert H. Blackburn

Improvement

247 Germination of seed of robust needlegrass by James A. Young, Charlie D. Clements, and T.A. Jones

Measurement/Sampling

251 Technical Note: A technique for conducting small-plot burn treatments by John L. Korfmacher, Jeanne C. Chambers, Robin J. Tausch, Bruce A. Roundy, Susan E. Meyer, and Stanley Kitchen

\section{Plant/Animal}

255 Consumption and dispersion of mesquite seeds by ruminants by Charles L. Kneuper, Cody B. Scott, and William E. Pinchak

260 Survival of 16 alfalfa populations space planted into a grassland by John R. Hendrickson and John D. Berdahl

266 Toxicity and development of tolerance in cattle to timber milkvetch by W. Majak, L. Stroesser, T. Lysyk, and J.W. Hall 
Published bimonthly-January, March, May, July, September, November

Copyright 2003 by the Society for Range Management

INDIVIDUAL SUBSCRIPTION is by membership in the Society for Range Management.

LIBRARY or other INSTITUTIONAL SUBSCRIP. TIONS on a calendar year basis are $\$ 140.00$ for the United States postpaid and $\$ 165.00$ for other countries, postpaid. Payment from outside the United States should be remitted in US dollars by international money order or draft on a New York bank.

BUSINESS CORRESPONDENCE, concerning subscriptions, advertising, reprints, back issues, and related matters, should be addressed to the Managing Editor, 445 Union Blvd., Suite 230 , Lakewood, Colorado 80228

EDITORIAL CORRESPONDENCE, concerning manuscripts or other editorial matters, should be addressed to the Editor, Gary Frasier, 7820 Stag Hollow Road, Loveland, Colorado 80538. Page proofs should be returned to the Production Editor, 3059A Hwy 92, Hotchkiss, CO 81419-9548.

INSTRUCTIONS FOR AUTHORS appear on the inside back cover of most issues. THE JOURNAL OF RANGE MANAGEMENT (ISSN 0022-409X) is published bimonthly for $\$ 56.00$ per year by the Society for Range Management, 445 Union Blvd., Ste 230, Lakewood, Colorado 80228. PERIODICALS POSTAGE paid at Denver, Colorado and additional offices.

POSTMASTER: Return entire journal with address change-Address Service Requested to Society for Range Management, 445 Union Blvd., Suite 230, Lakewood, Colorado 80228.

PRINTED IN USA

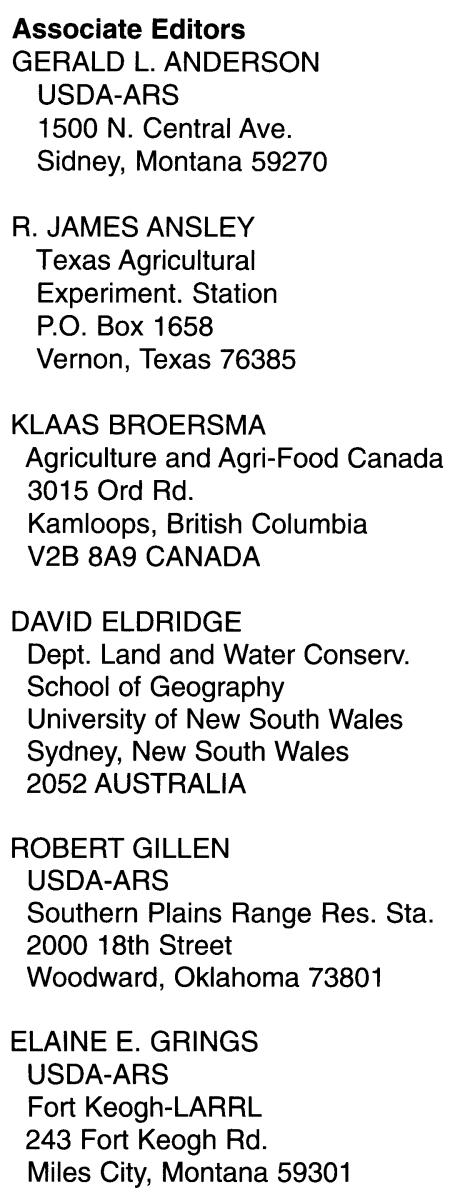

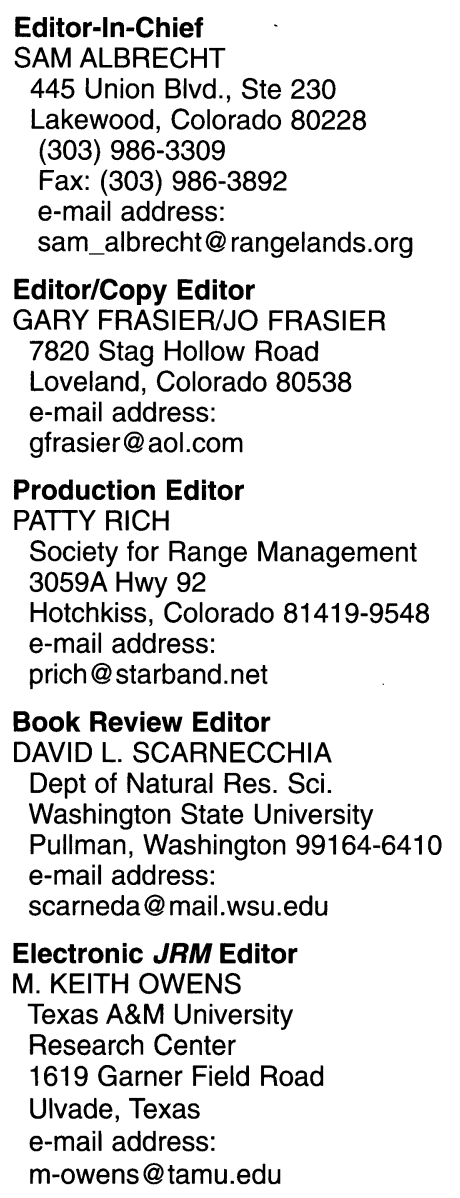

Plant Physiology

273 Adesmia subterranea Clos germination physiology and presowing treatments by Carlos A. Parera and Monica Ruiz

\section{Reclamation}

277 Germination of seeds of big and bottlebrush squirreltail by James A. Young, Charlie D. Clements, and Tom Jones.

Soils

282 Contrasting responses of Intermountain West grasses to soil nitrogen by Thomas A. Monaco, Douglas A. Johnson, Jeanette M. Norton, Thomas A. Jones, Keven J. Connors, Jay B. Norton, and Margaret B. Redinbaugh

291 Biological and chemical response of a grassland soil to burning by Liliana I. Picone, Gabriela Quaglia, Fernando O. Garcia, and Pedro Laterra

\section{Comment}

298 "Seasonal grazing affects soil physical properties of a montane riparian community" J. Range Manage. 55:49-56 by Everett M. White

\section{Rebuttal}

298 "Seasonal grazing affects soil physical properties of a montane riparian community" J. Range Manage. 55:49-56 by M.A. Wheeler, M.J. Trlica,

G.W. Frasier, and J.D. Reeder

Book Reviews

301 Resilience and the Behavior of Large-Scale Systems edited by Lance H. Gunderson and Lowell Pritchard Jr.; Native River. The Columbia Remembered by William D. Layman; Ranching West of the $\mathbf{1 0 0}^{\text {th }}$ Meridian. Culture, Ecology and Economics edited by Richard L. Knight

\author{
MARSHALL HAFERKAMP \\ USDA-ARS \\ Fort Keogh-LARRL \\ 243 Fort Keogh Rd. \\ Miles City, Montana 59301 \\ ROBERT LYONS \\ Texas A\&M University \\ Agricultural Research \& \\ Extension Ctr. \\ MICHAEL H. RALPHS \\ USDA-ARS \\ Poisonous Plant Lab \\ 1150 E $1400 \mathrm{~N}$ \\ Logan, Utah 84341-2881 \\ LARRY REDMON \\ TAREC \\ P.O. Drawer E \\ Overton, Texas 74684
}

P.O. Box 1849

Uvalde, Texas 78802

ROBERT A. MASTERS

Dow AgroSciences LLC

3618 South $75^{\text {th }}$ Street

Lincoln, Nebraska 68506

MITCHEL MCCLARAN

University of Arizona

301 Biological Science East

Tucson, Arizona 85721-0001

M. ANNE NAETH

University of Alberta

Dept. Renewable Resources

751 General Services Bldg.

Edmonton, Alberta

T6G 2H1 CANADA

ROBERT PEARCE
5028 Highway 6
Bishop, California 93514

NEIL RIMBEY

University of Idaho

16952 S. 10th Ave.

Caldwell, Idaho 83607

CAROLYN HULL SIEG

S.W. Science Complex 2500 South Pine Knoll

Flagstaff, Arizona 86001

STEVE WARREN

Colorado State University

Center for Environmental Management of Military Land

Dept. of Forestry Sciences

Fort Collins, Colorado 80523 


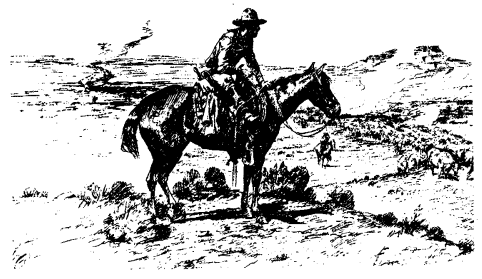

President

BOB BUDD

Red Canyon Ranch

350 Red Canyon Rd

Lander, Wyoming 82520-9417

1st Vice-President

MORT KOTHMANN

Texas A\&M University

Dept. Rangeland Ecology \& Mgt.

College Station, Texas 77843-0001

2nd Vice-President

ANGELA WILLIAMS

USDA-NRCS

RR1 Box 108

Paolia, Oklahoma 73074-9772

Executive Vice-President

SAM ALBRECHT

445 Union Blvd. Suite 230

Lakewood, Colorado 80228-1259

(303) 986-3309

Fax: (303) 986-3892

e-mail address:

samalbrecht_rangelands.org

Directors

2001-2003

JOHN TANAKA

Eastern Oregon Agr. Res. Center-Union

P.O. Box E

Union, Oregon 97883

GREG TEGART

BCMAFF

1690 Powick Rd, Suite 2000

Kelowna, BC V1X 7G5

CANADA

2002-2004

JOHN MALECHEK

Utah State University

Dept. of Rangeland Resources

UMC 5230

Logan, Utah 84322-0001

MARTIN VAVRA

EOARC

HC 71 Box 451, Hwy 205

Burns, Oregon 97720-9807

2003-2005

JEFF BURWELL

655 Parfet Street

Room E200C

Lakewood, Colorado 80215

ALLEN RASMUSSEN

College of Agr. \& Human Sciences

MSC 156

Kingsville, Texas 78363

The term of office of all elected officers and directors begins in February of each year during the Society's Annual Meeting.
THE SOCIETY FOR RANGE MANAGEMENT, founded in 1948 as the American Society of Range Management, is a nonprofit association incorporated under the laws of the State of Wyoming. It is recognized exempt from Federal income tax, as a scientific and educational organization, under the provisions of Section 501(c)(3) of the Internal Revenue Code, and also is classed as a public foundation as described in Section 509(a)(2) of the Code. The name of the Society was changed in 1971 by amendment of the Articles of Incorporation.

The objectives for which the corporation is established are:

-to properly take care of the basic rangeland resources of soil, plants, and water;

-to develop an understanding of range ecosystems and of the principles applicable to the management of range resources;

- to assist all who work with range resources to keep abreast of new findings and

techniques in the science and art of range management;

- to improve the effectiveness of range management to obtain from range resources the products and values necessary for man's welfare;

- to create a public appreciation of the economic and social benefits to be obtained from the range environment;

- to promote professional development of its members.

Membership in the Society for Range Management is open to anyone engaged in or interested in any aspect of the study, management, or use of rangelands. Please contact the Executive VicePresident for details.

The Journal of Range Management is a publication of the Society for Range Management. It serves as a forum for the presentation and discussion of facts, ideas, and philosophies pertaining to the study, management, and use of rangelands and their several resources. Accordingly, all material published herein is signed and reflects the individual views of the authors and is not necessarily an official position of the Society. Manuscripts from anyone-nonmembers as well as members-are welcome and will be given every consideration by the editors. Editorial comments by an individual are also welcome and, subject to acceptance by the editor, will be published as a "Viewpoint."

In Cooperation With: Some of the articles appearing in The Journal of Range Management (JRM) are presented in cooperation with The American Forage and Grassland Council (AFGC). This cooperation consists of $J R M$ acceptance of professional papers in forage grazing management and related subject areas from AFGC members and the appointment of 2 AFGC affiliated associate editors to JRM's Editorial Staff. The American Forage and Grassland

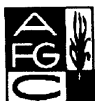
Council Offices: P.O. Box 94, Georgetown, Texas 78627; Larry Jeffries, President; Dana Tucker, Executive Secretary.

Contribution Policy: The Society for Range Management may accept donations of real and/or personal property subject to limitations set forth by State and Federal law. All donations shall be subject to management by the Executive Vice President as directed by the Board of Directors and their discretion in establishing and maintaining trusts, memorials, scholarships, or other types of funds. Individual endowments for designated purposes can be established according to Society policies. Gifts, bequests, legacies, devises, or donations not intended for establishing designated endowments will be deposited into the SRM Endowment Fund. Donations or requests for further information on Society policies can be directed to the Society for Range Management, Executive Vice-President, 445 Union Blvd., Suite 230, Lakewood, Colo. 80228-1259. We recommend that donors consult Tax Advisors in regard to any tax consideration that may result from any donation. 


\title{
Distribution of Russian knapweed in Colorado: Climate and environmental factors
}

\author{
SARAH C. GOSLEE, K. GEORGE BECK AND DEBRA P.C. PETERS
}

Authors are Ecologist, USDA-ARS, Jornada Experimental Range, Las Cruces, N.M. 88003; Professor, Department of Bioagricultural Sciences and Pest Management, Colorado State University, Fort Collins, Colo. 80523; and Landscape Ecologist, USDA-ARS, Jornada Experimental Range, Las Cruces, N.M. 88003.

\begin{abstract}
Russian knapweed (Acroptilon repens (L.) DC.) was introduced to the western United States during the early 1900s. This invasive perennial was a contaminant of alfalfa seed, and was distributed widely across Colorado. Thus, current distributions reflect the climate and soils tolerances of Russian knapweed, and management history, rather than dispersal processes. We surveyed extension and weed agents across Colorado, and were able to locate 528 current or recently eliminated Russian knapweed stands. These patches were superimposed on climate and soils maps to identify $1 \mathrm{~km}$ grid cells that were known to contain Russian knapweed. The status of Russian knapweed within a cell was used as the dependent variable in a logistic regression model to define the environmental envelope for this species. At the scale of our analysis, Russian knapweed was most prevalent on finetextured soils (clay and clay loam), and in warmer, drier regions of Colorado (precipitation $18-73 \mathrm{~cm} / \mathrm{yr}$, mean annual temperature $1-12^{\circ} \mathrm{C}$ ). June precipitation was the most important single factor, although nearly all environmental, annual, and monthly climatic factors were significantly related to Russian knapweed occurrence. The multivariate logistic regression model we developed was used to predict the probability of occurrence of Russian knapweed for the entire state of Colorado. Our predictions matched the areas of highest abundance of Russian knapweed from a new field survey, and also indicated areas of high risk that were not identified by the field survey.
\end{abstract}

Key Words: generalized additive model, geographic information system, logistic regression

Invasive species are a severe problem world-wide. While control or eradication are usually the ultimate goals, in many cases scientists lack even basic information about the biology and ecology of invasive species. Knowledge of the distribution of a species with respect to environmental and climatic factors can be used to prioritize management efforts for those regions where an invasive is most likely to succeed (Panetta and Dodd 1987, Higgins et al. 1999). An understanding of climatic controls on species distribution also makes it possible to predict changes in distribution under potential climate change scenarios (Franklin 1998).

This research was funded by the USDA National Research Initiative Competitive Grants Program award \#9600468. We greatly appreciate the cooperation of the many Colorado County Extension Agents and Weed Supervisors who assisted us in identifying the locations of Russian knapweed patches.

Manuscript accepted 27 Jul. 02

\section{Resumen}

EI "Russian knapweed" (Acroptilon repens (L.) DC.) se introdujo al oeste de los Estados Unidos a inicio del siglo pasado, en los primeros años de 1900's. Esta especie perenne invasora fue un contaminante de la semilla de alfalfa y se distribuyo ampliamente a través de Colorado. Así que, su distribución actual refleja la tolerancia del "Russian knapweed" al clima y suelos e historial de manejo mas que el proceso de dispersión. Inspeccionamos agentes de extensión y de control de maleza del estado de Colorado y fuimos capaces de localizar 528 poblaciones de "Russian knapweed" actual o recientemente eliminadas. Estos parches fueron sobrepuestos en mapas de suelo y clima para identificar en una cuadricula celdas de $1 \mathbf{k m}^{2}$ en las que sabíamos que el "Russian knapweed" estaba presente. El posición del "Russian knapweed" dentro de la celda se uso como variable dependiente en un modelo de regresión logística para definir el rango ambiental de esta especie. En la escala de nuestro estudio, el "Russian knapweed" prevaleció mas en suelos de textura fina (arcillosos o franco arcillosos) y en las regiones cálidas y secas del estado de Colorado (precipitación de 18-73 $\mathrm{cm} / \mathbf{a n ̃ o}$, temperatura media anual de $1-12^{\circ} \mathrm{C}$ ). La precipitación de Junio fue el factor individual mas importante, aunque casi todos los factores ambientales climáticos, anuales y mensuales, estuvieron significativamente relacionados a la ocurrencia del "Russian knapweed". El modelo multivariado de regresión logística que desarrollamos se uso para predecir la probabilidad de ocurrencia del "Russian knapweed" en todo el estado de Colorado. Nuestras predicciones concordaron con las áreas de mayor abundancia de "Russian knapweed" identificadas en un nuevo muestreo de campo y también indicaron las áreas con mayor riesgo que no fueron identificadas por el reconocimiento de campo.

Russian knapweed (Acroptilon repens (L.) DC.) is a long-lived (> $75 \mathrm{yr}$ ), highly aggressive $\mathrm{C}_{3}$ perennial forb. It was introduced to the US in contaminated alfalfa seed during the early $1900 \mathrm{~s}$ (Rogers 1928, Watson 1980). This invasive weed has large economic and ecological impacts, including reduction of forage quality and poisoning of horses, increased soil erosion, and reduced wildlife populations (Watson 1980, Roché and Roché 1988, 1991). It is a legislated noxious weed in Colorado (State of Colorado 1996), and is a problem species in every western state (Roché and Roché 1991). It was introduced to Colorado in contaminated alfalfa seed, and has been widely distributed across the state (Rogers 1928). 
Both field observations and simulation results show that Russian knapweed does not do equally well on all soil types and under all climatic regimes found in Colorado (Goslee et al. 2001, Goslee, S.C., K.G. Beck, and D.P.C. Peters, unpublished data). If we can identify the environmental distribution limits of this species, that information can be used to a) identify areas most vulnerable to Russian knapweed invasion under current conditions; and b) predict where Russian knapweed may become a problem under proposed climate change scenarios. Our objectives were to map known Russian knapweed stands across Colorado, and to use the accumulated data to describe the environmental and climatic variables important in determining Russian knapweed distribution. Russian knapweed is a particularly good candidate for this type of analysis since seeds were widely distributed and the location of current stands should be related to environmental conditions rather than dispersal constraints. Likewise, Colorado spans a relatively wide range of climatic conditions, so that it should be possible to identify both maxima and minima for temperature and precipitation descriptors.

\section{Methods}

To obtain the locations of patches of Russian knapweed, we surveyed cooperative extension agents and weed supervisors across the state of Colorado. All patch locations were entered into a geographic information system (GIS) database using ArcInfo (ESRI, Inc.). We extracted soil texture data (percentage sand, silt, and clay) from STATSGO soils maps (USDA 1991). Elevation data were obtained from 1:250,000-scale digital elevation models (USGS 1990). Temperature and precipitation maps for Colorado from the PRISM database were used as a source for minimum and maximum monthly temperature and monthly precipitation, which were used to calculate annual averages and totals (Daly et al. 1994). All GIS data were rescaled to a consistent pixel size (1 $\mathrm{km}$ ), resulting in 267310 grid cells within Colorado. The Russian knapweed patch locations were superimposed on the gridded state map to create another GIS layer indicating presence or absence of Russian knapweed in each grid cell. Although it is highly unlikely that we were able to identify every location where Russian knapweed is currently found, the survey methodology allowed us to obtain a repre-

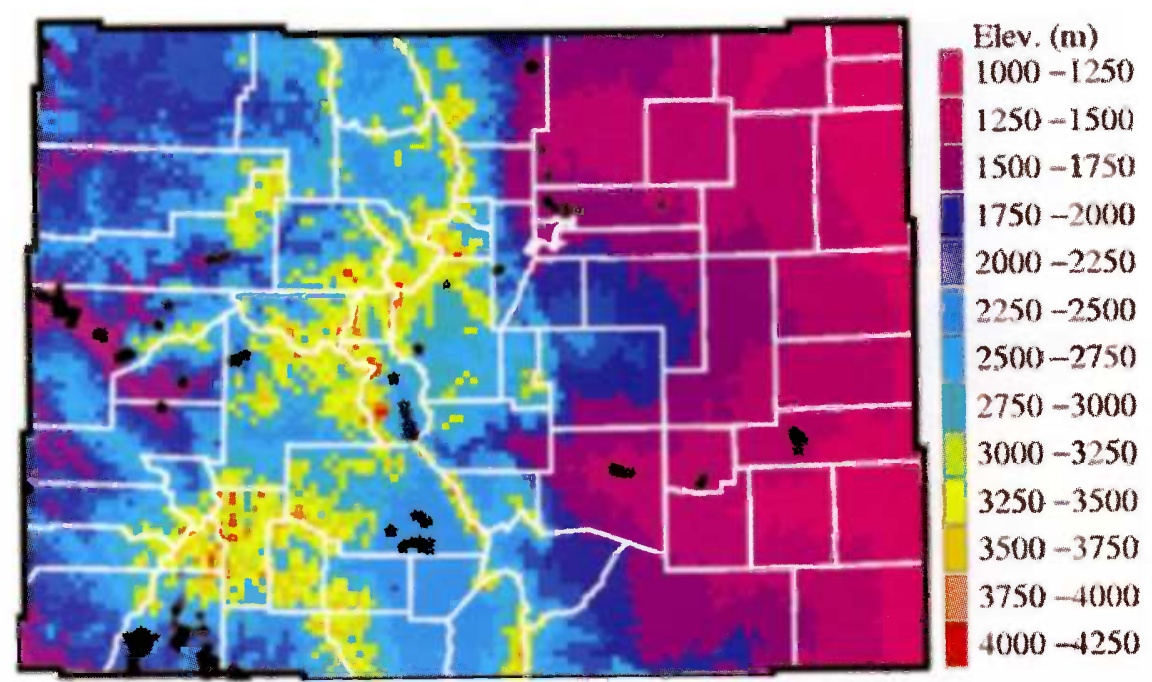

Fig. 1. Locations of known Russian knapweed stands (black stars) in relation to elevation (USGS 1990). County boundaries are shown as white lines. sentative sample across the state. We compared the distribution of soils and climate values for the patches to the distribution of these variables for Colorado as a whole, not to the areas where no Russian knapweed was reported since we cannot be certain that those areas are actually free of Russian knapweed.

Logistic regression is commonly used to fit species presence/absence to environmental factors, and to predict probability of species occurrence in new areas (Franklin 1995). The form of the regresway that a species responds to environmental factors. Ecologists often assume that species follow a linear or a normal distribution, but in many cases this assumption is incorrect. Generalized additive models (GAMs) provide an alternative way to fit a curve describing species sion is based on assumptions about the responses without making any assumptions about distribution shape, and thus should more closely fit data of any form (Frescino et al. 2001). The drawback to GAMs is that it is much more computationally challenging to fit and interpret these models, and to use them for predictive purposes.

We fit 3 separate curves using S-Plus (Version 3.4, MathSoft, Inc.): linear logistic regression (assuming linear distribution), second order polynomial logistic regression (assuming normal distribution), and a spline-smoothed generalized additive model (no distributional assumptions), to identify the most appropriate functional form for each variable (Chambers and Hastie 1992, Venables and Ripley 1994). Models were initially fit for each environmental variable separately. To identify the best-fitting models, we examined the

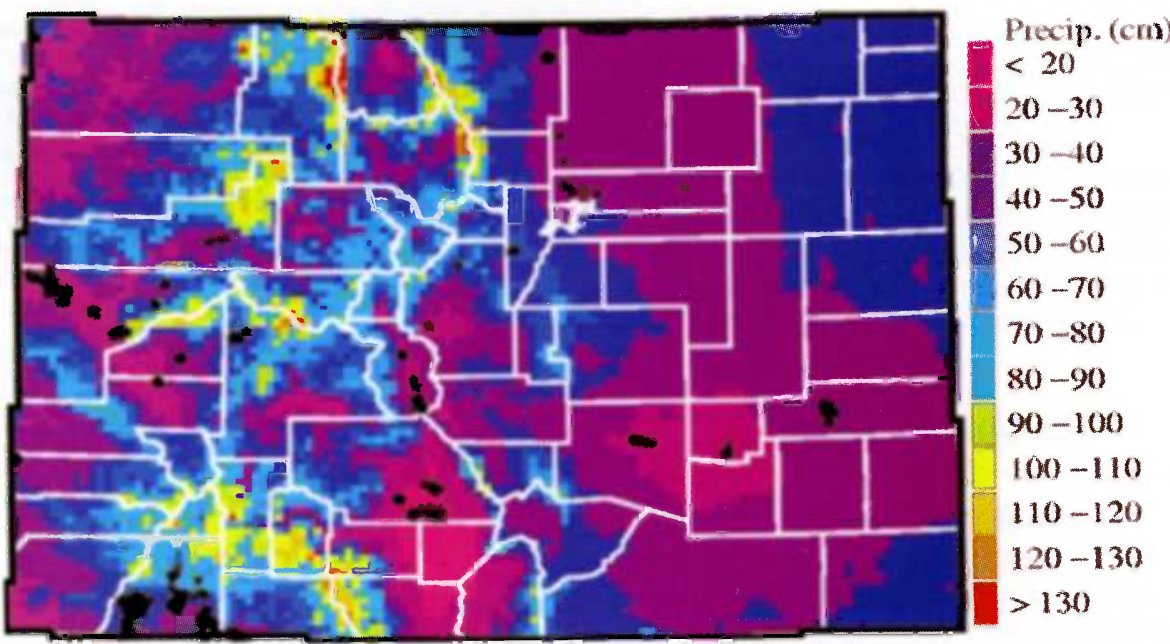

Fig. 2. Locations of known Russian knapweed stands (black stars) in relation to annual precipitation (Daly et al. 1994). County boundaries are shown as white lines. 


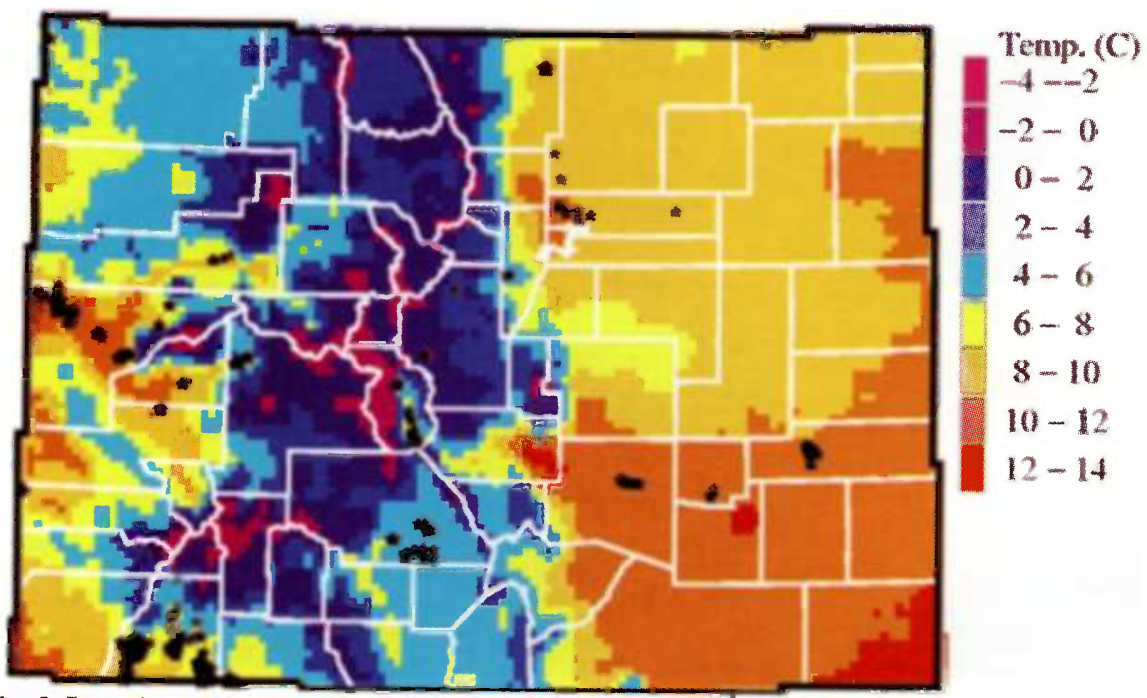

Fig. 3. Locations of known Russian knapweed stands (black stars) in relation to mean annual temperature (Daly et al. 1994). County boundaries are shown as white lines.

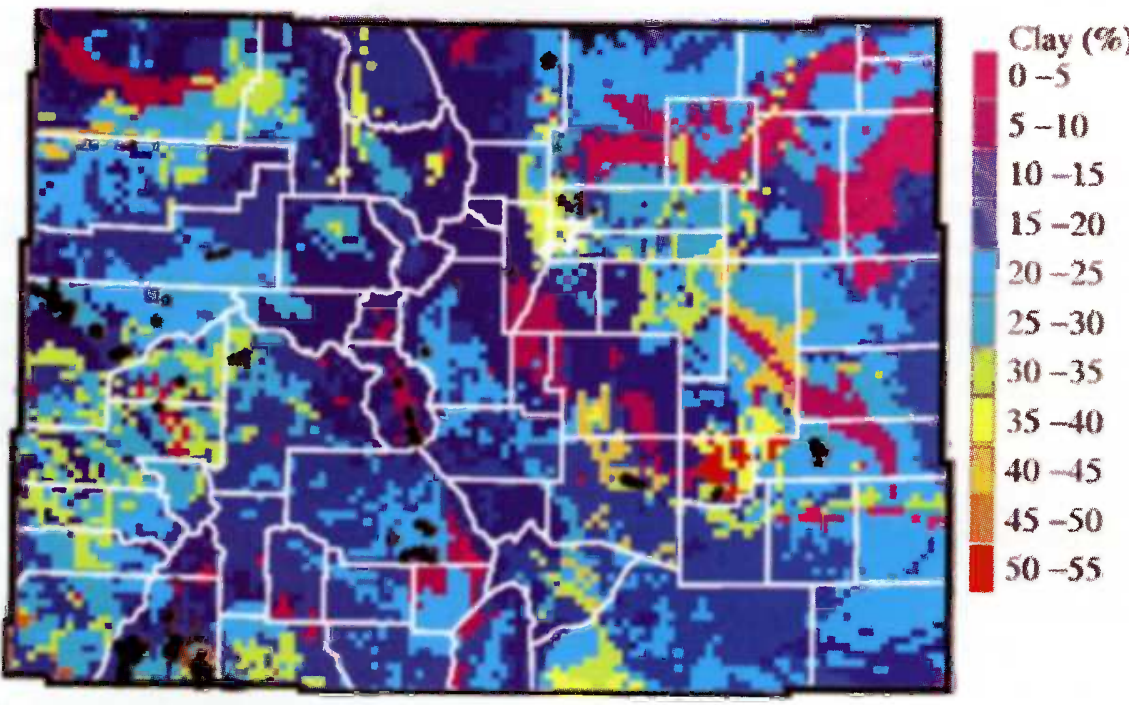

Fig. 4. Locations of known Russian knapweed stands (black stars) in relation to soil texture (USDA 1991). County boundaries are shown as white lines. stands were located around reservoirs or in river valleys. Russian knapweed patches were found mostly in areas of low to moderate annual precipitation $(18-73 \mathrm{~cm} / \mathrm{yr}$; Fig. 2) and moderate to high mean annual temperature ( $1-12 \mathrm{C}$; Fig. 3). Many sites were found on fine-textured soils. Nearly $40 \%$ of stands were found on clay loam or clay soils, although those types make up less than $16 \%$ of Colorado soils (Fig. 4). A map and list of coordinates for Russian knapweed patches are available from the authors. A previous survey identified location only to the county level, but general regions correspond well with our reported infestations (Maddox et al. 1985).

Summary plots for the entire state of Colorado and for identified Russian knapweed locations for annual totals and for a winter and a summer month are shown in Fig. 5. The precipitation variables (annual, maximum monthly, minimum monthly, June and December) showed the greatest differences between Russian knapweed sites and the state as a whole, indicating that precipitation is an important variable for this species. Certain temperature variables (annual, maximum monthly, and June maximum) showed a trend of Russian knapweed towards warmer sites. These summaries also suggest that these patches span most of its climatic and environmental envelope since Russian knapweed was rarely found in the extremes of any of the variables selected.

We tested models of Russian knapweed distribution in relation to elevation, soil texture (percentages sand, silt, and clay), and 6 annual climate summary parameters: minimum and maximum monthly precipitation, total annual precipitation, mean minimum and maximum temperature, and deviance explained by each, and also compared the models formally using a Chisquared test (Venables and Ripley 1994). Those explanatory variables with the strongest relationships to Russian knapweed presence were combined in a multivariate logistic regression. Computer limitations prevented an in-depth investigation of multivariate and interaction models.

\section{Results and Discussion}

We were able to identify the locations of 528 Russian knapweed stands from our survey. These patches were found throughout the state, except for the northeastern plains and high elevations in the mountains (Fig. 1). Large clusters of
Table 1. Polynomial regression equations for individual environmental variables of the form $y=$ Intercept $+\operatorname{Coef} 1 * x+\operatorname{Coef} 2 * x^{2}$. The dependent variable $(y)$ is the natural $\log$ of the probability of Russian knapweed presence. For 2 variables, soil clay and maximum monthly precipitation, the polynomial term was not significant, and the linear equation is given. The last column gives the percentage of the residual deviance explained by the appropriate model.

\begin{tabular}{lcrrr}
\hline \hline & Intercept & Coefl & Coef2 & $\%$ Dev. \\
\hline Elevation (m) & -17.45 & 0.013 & $-3.25 \mathrm{E}-06$ & 4.44 \\
Soil clay (\%) & -7.75 & 0.072 & & 3.27 \\
Annual precipitation (cm) & -2.24 & -0.127 & $6.09 \mathrm{E}-04$ & 4.77 \\
Minimum monthly precip. (cm) & -9.03 & 4.691 & $-1.47 \mathrm{E}+00$ & 4.62 \\
Maximum monthly precip. (cm) & -2.56 & -0.661 & & 7.68 \\
Mean annual temperature (C) & -10.87 & 1.338 & $-8.36 \mathrm{E}-02$ & 3.56 \\
Minimum monthly temp. (C) & -13.92 & -1.242 & $-4.76 \mathrm{E}-02$ & 1.07 \\
Maximum monthly temp. (C) & -32.64 & 1.751 & $-2.85 \mathrm{E}-02$ & 2.66 \\
June precip. (cm) & -1.85 & -1.945 & $1.37 \mathrm{E}-01$ & 13.79 \\
June minimum temp. (C) & -8.63 & 0.821 & $-5.32 \mathrm{E} .02$ & 2.71 \\
June maximum temp. (C) & -28.32 & 1.578 & $-2.75 \mathrm{E}-02$ & 3.08 \\
December precip. (cm) & -7.88 & 1.550 & $-2.36 \mathrm{E}-01$ & 3.73 \\
December minimum temp. (C) & -9.58 & -0.719 & $-3.50 \mathrm{E}-02$ & 1.19 \\
December maximum temp. (C) & -7.81 & 1.220 & $-1.49 \mathrm{E}-01$ & 5.77 \\
\hline
\end{tabular}




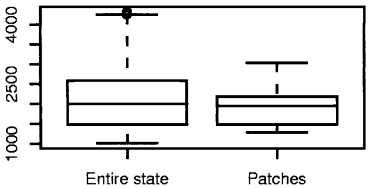

Min. monthly precip. (cm)

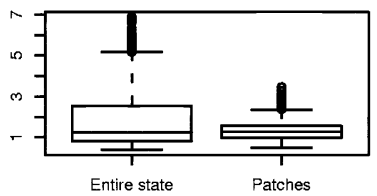

June precip. (cm)

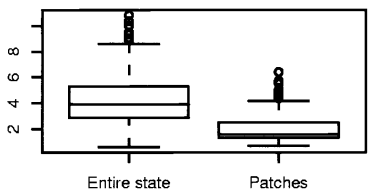

December precip. (cm)

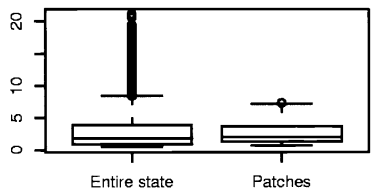

Soll clay (\%)

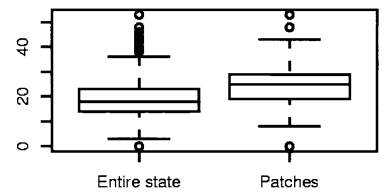

Max. monthly precip. (cm)

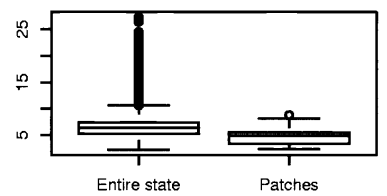

June min. temp. (C)

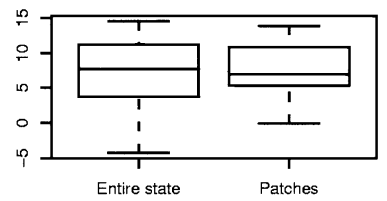

December min. temp. (C)

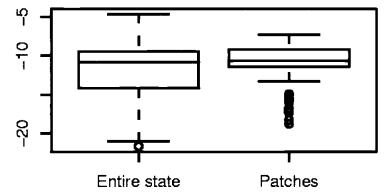

Annual precip. (cm)

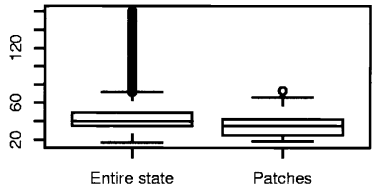

Min. monthly temp. (C)

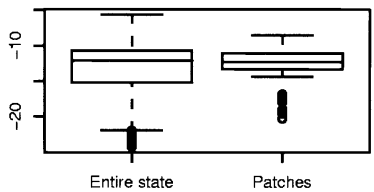

June max. temp. (C)

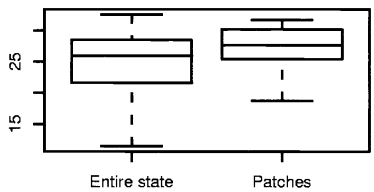

December max. temp. (C)

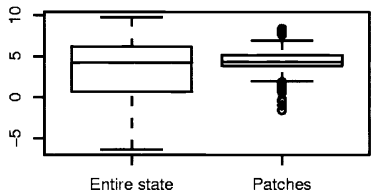

Mean annual temp. (C)

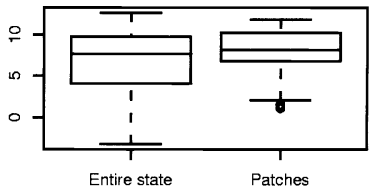

Max. monthly temp. (C)

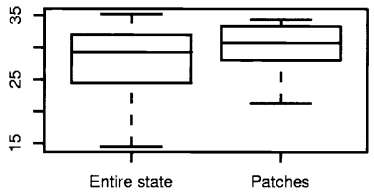

Fig. 5. Comparison of major environmental and climatic variables across the entire state of Colorado and for locations where Russian knapweed was found. The box area contains the middle $50 \%$ of the data, and the median is voided from the box so that skewness can be assessed. Outliers are shown as lines beyond the whiskers, which indicate 1.5 times the interquartile range (S-Plus Version 3.4, MathSoft, Inc.).

mean annual temperature. We also tested 3 climate parameters for each month: minimum and maximum temperature and total precipitation. Each of these 46 parameters were highly significant explanatory variables for both the polynomial and spline models $(\mathrm{P}<0.001)$, and all but October precipitation were also significant for the linear model. June precipitation was the strongest single predictor, explaining nearly $15 \%$ of the total deviance in Russian knapweed occurrence (Fig. 6). Maximum monthly and annual precipitation, winter maximum temperature, and elevation were also strong predictors.

As we expected, the spline-fitting model most closely matched the data in all cases. The shape of the polynomial model was surprisingly similar to that of the spline model for all strong predictor variables, and the linear model provided a generally poorer fit (Fig. 7). Although the polynomial model was not quite as good a fit as the spline model, it is more straightfor- ward conceptually and it is easier to parameterize and to use for prediction. Because of these considerations, and the similarity between the shapes of the spline and polynomial models, we have chosen to focus on the latter.

Regression equations for the strongest single-variable polynomial models are given in Table 1. Two of the variables, soil clay and maximum monthly precipitation, were better fit by linear than polynomial relationships, so the coefficients for

Table 2. Coefficients for the multivariate logistic polynomial model containing elevation and the strongest soil texture, precipitation and temperature variables. The dependent variable $(y)$ is the natural log of the probability of Russian knapweed presence. NS indicates terms which were not significant in the full model, and are not included in the model presented here. This model explained $19 \%$ of the total deviance.

\begin{tabular}{lr}
\hline \hline & Coefficient \\
\hline Intercept & $-2.43 \mathrm{E}+000$ \\
Elevation & $-1.97 \mathrm{E}-003$ \\
(Elevation $^{2}$ & $2.30 \mathrm{E}-007$ \\
Clay & $3.37 \mathrm{E}-002$ \\
(Clay) $^{2}$ & $\mathrm{NS}$ \\
June precipitation & $-9.04 \mathrm{E}-001$ \\
(June precipitation $^{2}$ & $\mathrm{NS}$ \\
December maximum temp. $^{2}$ & $7.28 \mathrm{E}-001$ \\
(December maximum temp. $^{2}$ & $-7.61 \mathrm{E}-002$ \\
\hline
\end{tabular}



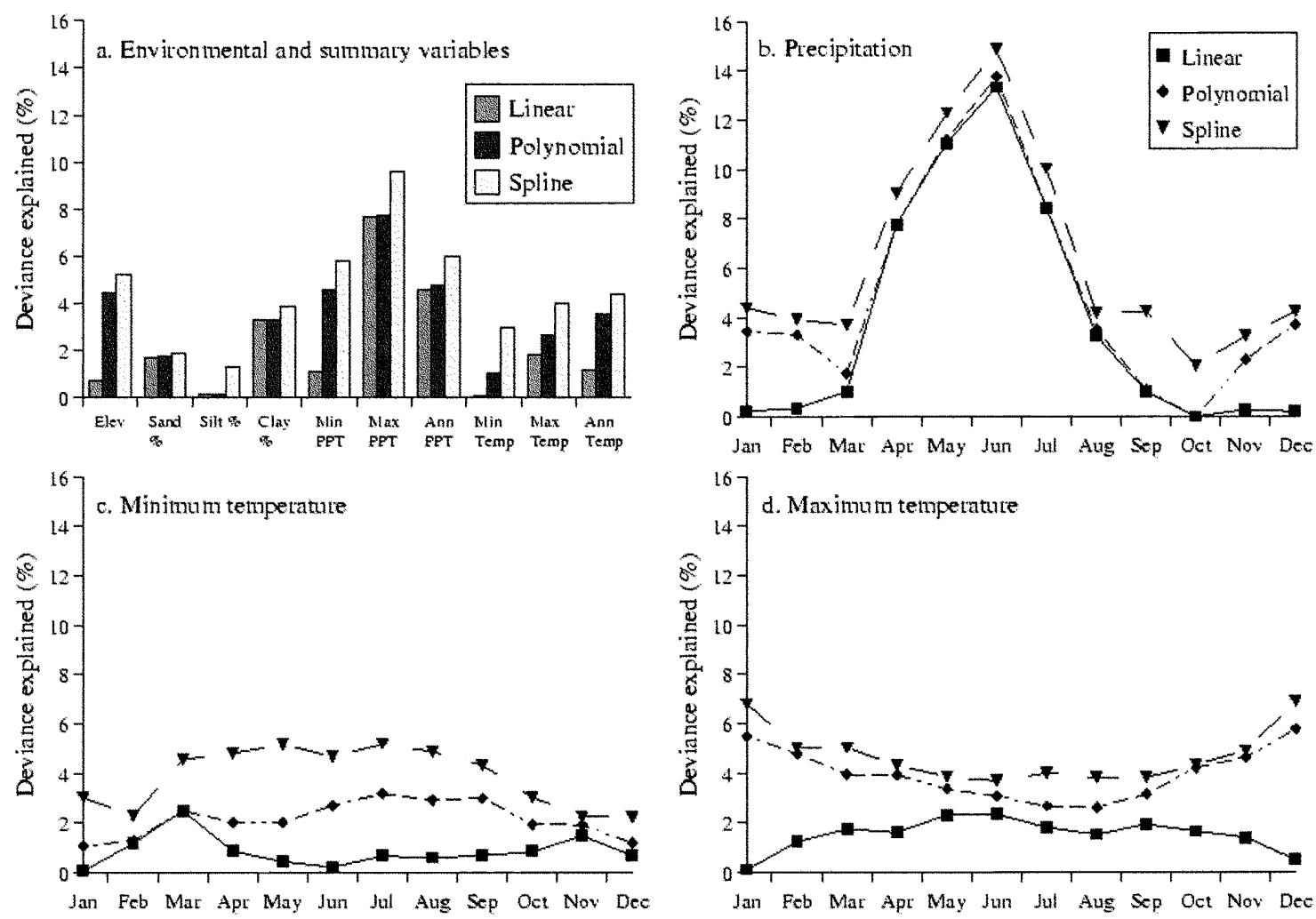

Fig. 6. Percentage of deviance in Russian knapweed occurrence explained by single-variable linear logistic regression, polynomial logistic regression and spline-smoothed generalized additive models.

that form are shown. These equations can be used to predict the probability of Russian knapweed occurrence in a novel area within our realm of inference. A polynomial model including elevation, clay, June precipitation, maximum monthly precipitation and December minimum temperature (the most important environmental, soil, precipitation and temperature variables) explained $19 \%$ of the total deviance (Table 2).

The fitted values from the multivariate polynomial model were used to draw a map of Colorado showing the predicted probability of occurrence for Russian knapweed in each grid cell (Fig. 8). To assess the validity of our model, we compared our predictions to a recently-released map of Russian knapweed abundance developed by the Colorado Department of Agriculture (2002). While the major areas of infestation identified by the Colorado Department of Agriculture correspond closely to areas identified by the logistic regression model (primarily in river valleys), the regression model highlighted a greater portion of the state as potential Russian knapweed habitat. Most of these mismatches occur in counties where Russian knapweed is known to exist, but has not yet been reported to the Colorado
Department of Agriculture. The close similarity of the independently-derived maps suggests that the multivariate logistic regression model adequately describes potential Russian knapweed habitat.

Our results demonstrated that Russian knapweed was found more often on sites with low June precipitation, low elevation, high percentage soil clay, and high December maximum temperatures. The environmental and climatic factors most strongly related to Russian knapweed occurrence were probably determined by its phenology and physiology. Russian knapweed is a $\mathrm{C}_{3}$ species, and begins to grow in the spring as soon as the soil no longer freezes (Watson 1980). Sites with warm winter temperatures may encourage earlier growth, allowing this perennial weed to become active before its competitors. Russian knapweed has a deep root system, which likely allows it to do well in dry areas (Selleck 1964, Watson 1980). Its relationship to precipitation patterns supports that assumption. In sites with low spring precipitation, this deep-rooted perennial may be able to establish an advantage over annuals or shallow-rooted perennials and this advantage could persist throughout the growing season. Information in the literature conflicts over the role of soil texture on Russian knapweed success. Within its native range, Russian knapweed can be found in a wide range of environmental conditions, including sandy, stony and clay soils (Komarov 1963). In the western US and Canada, where Russian knapweed has been introduced, early studies claimed that soil texture is unimportant (Rogers 1928, Watson 1980), but more recent research suggests that this species invades more successfully on fine-textured than on coarser soils (Goslee et al. 2001, Goslee, S.C., K.G. Beck, and D.P.C. Peters, unpublished data). Our analysis supports the observation that Russian knapweed invasion occurs more often on soils with a high clay content, although that relationship was not as strong as with other environmental variables.

Even when including several variables in the model, we were able to explain only a small portion of the total variance in Russian knapweed occurrence. This could be due to the relatively small number of known stands, or because information on other biologically important variables was unavailable. The weak relationships are most likely due to the coarse grain $(1 \mathrm{~km})$ of the available environmental data. The distributions of weeds, including Russian knapweed, are often related to distur- 

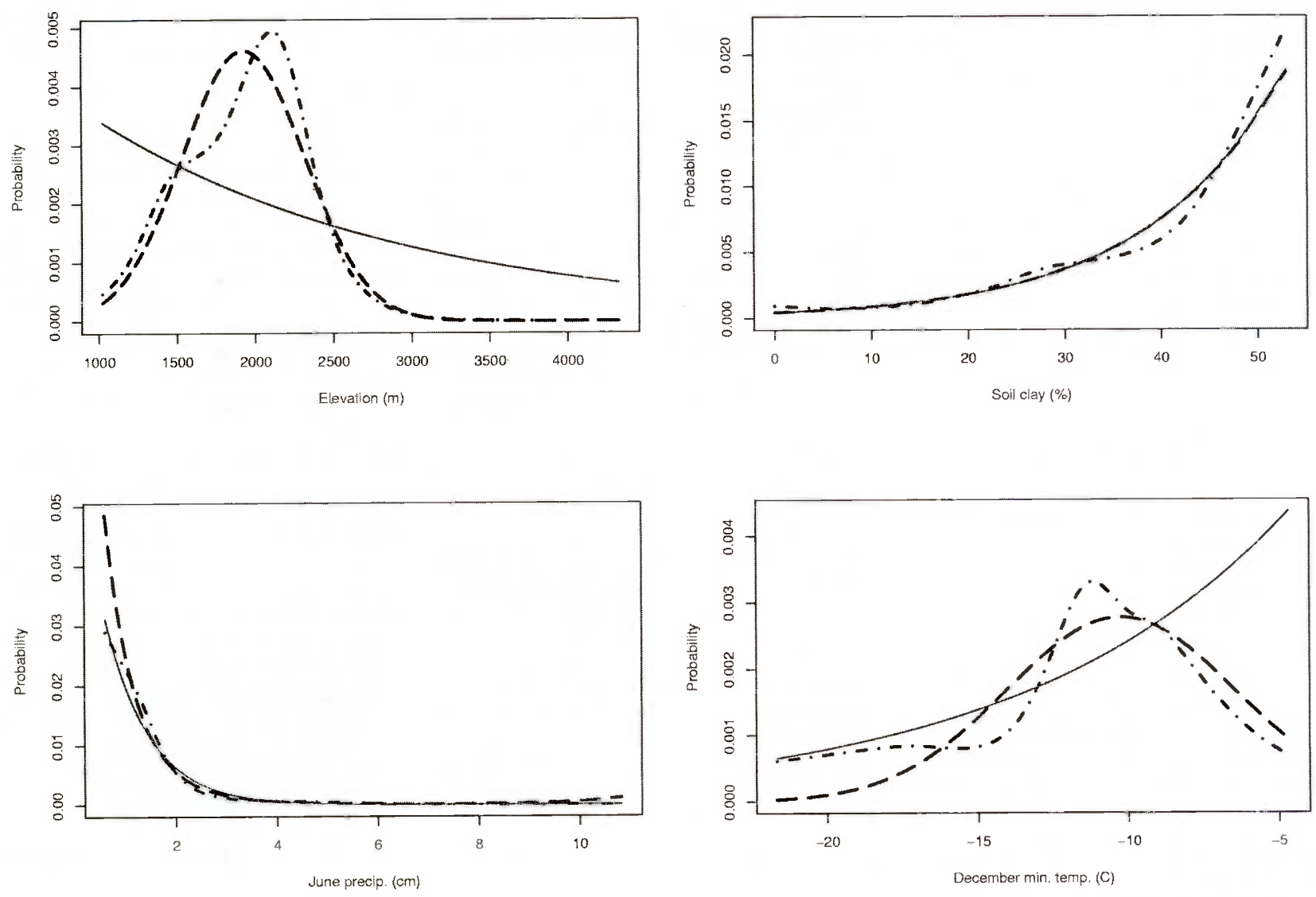

Fig. 7. Comparison of the fitted curves for linear logistic regression (solid line), polynomial logistic regression (dashed line) and spline smoothed generalized additive model (dot-dashed line) for four predictor variables. Each shows a different response of the probability of Russian knapweed presence to that variable.

bances that allow them to become established. The location of the stands identified with respect to roadsides, reservoirs and other disturbances is not known.
Although environmental conditions must be correct for long-term survival, disturbance could determine where Russian knapweed became established, and thus affect the strength of the regression relationship by reducing the number of potential sites where it was actually present. Competitive effects of the original vegeta-

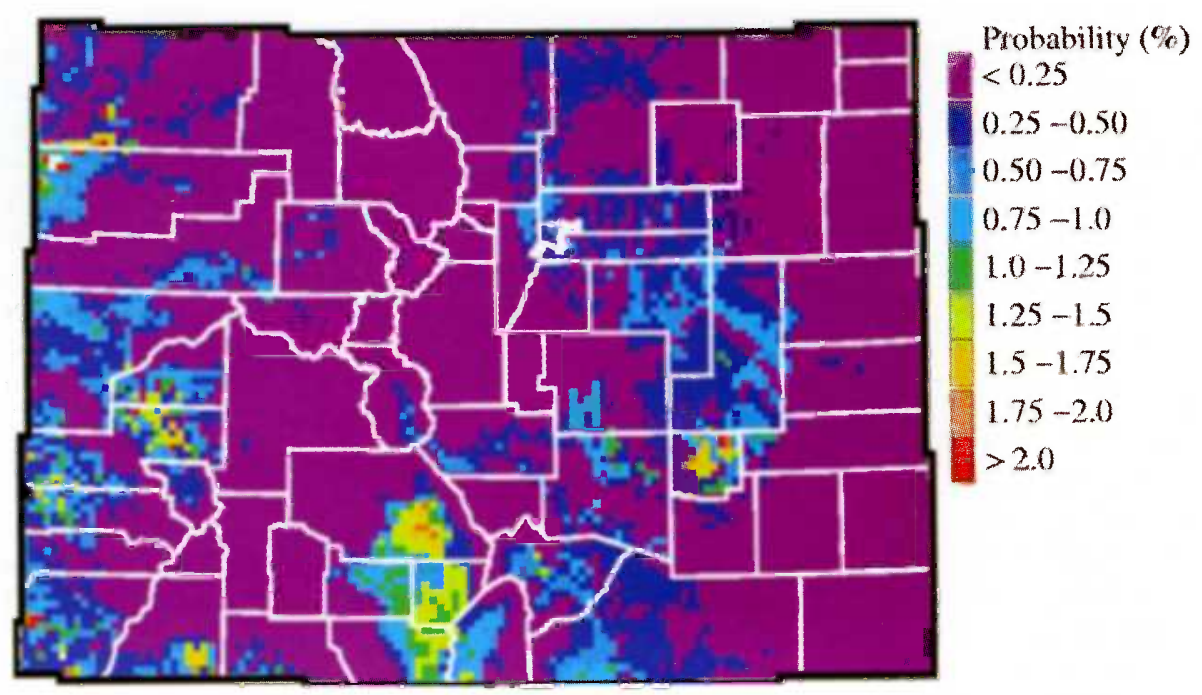

Fig. 8. Probability of occurrence of Russian knapweed across Colorado derived from the multivariate logistic regression model in Table 2. 
tion could also be important (Panetta and Mitchell 1991).

Our survey of Russian knapweed locations across Colorado identified several important variables, especially June precipitation, elevation, soil clay, and December maximum temperatures. The physiology of Russian knapweed makes these variables important for its success. The relationships identified here can be used for prediction of Russian knapweed success in novel environments, and under novel climatic conditions.

\section{Literature Cited}

Chambers, J.M. and T.J. Hastie. 1992. Statistical models in S. Wadsworth and Brooks/Cole, Pacific Grove, Calif.

Colorado Department of Agriculture. 2002. Russian knapweed 2001 distribution and abundance in Colorado. http://www.ag.state.co.us/dpi/weeds/mapping/russianknapweed.g if. (Accessed 5 April, 2002.)

Daly, C., R.P. Nielson, and D.L. Phillips. 1994. A statistical-topographic model for mapping climatological precipitation over mountainous terrain. J. Appl. Meteorol. 33:140-158.

Franklin, J. 1995. Predictive vegetation mapping: geographic modelling of biospatial patterns in relation to environmental gradients. Prog. Physical Geog. 19:474-499.
Franklin, J. 1998. Predicting the distribution of shrub species in southern California from climate and terrain-derived variables. J. Veg. Sci. 9:733-748.

Frescino, T.S., T.C. Edwards, Jr., and G.G. Moisen. 2001. Modeling spatially explicit forest structural attributes using Generalized Additive Models. J. Veg. Sci. 12:15-26.

Goslee, S.C., D.P.C. Peters, and K.G. Beck. 2001. Modeling invasive weeds in grasslands: the role of allelopathy in Acroptilon repens invasion. Ecol. Model. 139:31-45.

Higgins, S.I., D.M. Richardson, R.M. Cowling, and T.H. Trinder-Smith. 1999. Predicting the landscape-scale distribution of alien plants and their threat to plant diversity. Conserv. Biol. 13:303-313.

Komarov, V.L. 1963. Flora of the U.S.S.R Published for the Smithsonian Institution and the NSF by the Israel Program for Scientific Translations. Jerusalem, Israel.

Maddox, D.M., A. Mayfield, and N.H. Poritz. 1985. Distribution of yellow starthistle (Centaurea solstitialis) and Russian knapweed (Centaurea repens). Weed Sci. 33:315-327.

Panetta, F.D. and J. Dodd. 1987. Bioclimatic prediction of the potential distribution of skeleton weed Chondrilla juncea L. in western Australia. J. Australian Inst. Agricultural Sci. 53:11-16.

Panetta, F.D. and N.D. Mitchell. 1991. Homocline analysis and the prediction of weediness. Weed Res. 31:273-284.
Roché, B.F., Jr. and C.T. Roché. 1991. Identification, introduction, distribution, ecology and economics of Centaurea species. p. 275-291 In: L.F. James and J.O. Evans. (eds.) Noxious Range Weeds. Westview Press, Boulder, Colo.

Roché, C.T. and B.F. Roché, Jr. 1988. Distribution and amount of four knapweed (Centaurea L.) species in eastern Washington. Northwest Sci. 62:242-253.

Rogers, C.F. 1928. Canada thistle and Russian knapweed and their control. Colorado Exp. Sta. Bull. 348, Fort Collins, Colo.

Selleck, G.W. 1964. A competition study of Cardaria spp. and Centaurea repens. Proc. Seventh Brit. Weed Control Conf. 7:569-576.

State of Colorado. 1996. Colorado noxious weed act. Colorado House Bill 96-108, Denver, Colo.

USDA Soil Conservation Service. 1991. State Soil Geographic Data Base (STATSGO): Data Users Guide. Misc. Publ. No. 1492.

USGS. 1990. Digital Elevation Models, National Mapping Program Technical Instructions, Data Users Guide 5, Second Printing (Revised), Reston, Virg.

Venables, W.N. and B.D. Ripley. 1994. Modern applied statistics with S-plus. Springer-Verlag, New York, N.Y.

Watson, A.K. 1980. The biology of Canadian weeds. 43. Acroptilon (Centaurea) repens (L.) DC. Can. J. Plant Sci. 60:993-1004. 


\title{
Fall grazing affects big game forage on rough fescue grasslands
}

\author{
JEFFREY J. SHORT AND JAMES E. KNIGHT
}

Authors are Graduate Sudent and Extension Wildlife Specialist, Department of Animal and Range Sciences, Montana State University, Bozeman, Mont. 59717.

Abstract

Prescribed cattle grazing is often used to purposely enhance wildlife habitat. This study investigated the effects of fall cattle (Bos taurus) grazing intensity on elk (Cervus elaphus) and deer (Odocoileus spp.) forage in the following spring and summer. These effects were examined on rough fescue (Festuca scabrella Torr.) range on the Blackfoot Clearwater Wildlife Management Area in west central Montana. Cattle were grazed in enclosures during the fall of 1997 and 1998. A randomized complete block design with 5 replications of enclosures per year was used. Grazing levels were $0 \%$ removal (control), $50 \%$ removal, $70 \%$ removal, and $90 \%$ removal of herbaceous standing crop. To evaluate elk and deer forage, measurements were obtained in spring and summer on green grass standing crop, green forb standing crop, percent green vegetation, species richness, and plant species composition. There were no differences among grazing levels for plant species composition based on canopy coverage,

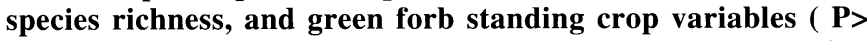
0.10). The $50 \%$ and $90 \%$ treatments reduced green standing crop in spring $(P=0.07)$ but not in summer $(P>0.10)$. Grazing treatments increased percent green vegetation $(P<0.01)$. Fall cattle grazing can be used as a wildlife habitat improvement tool to reduce unpalatable standing dead material. The $70 \%$ removal treatment was the most favorable for habitat improvement without degrading the range.

Key Words: Cervus elaphus, Festuca scabrella, Odocoileus spp., livestock-wildlife relations, prescribed livestock grazing

The compatibility of livestock and wildlife on western ranges has been discussed often (Anderson and Scherzinger 1975). Managers traditionally considered livestock activities in wildlife habitat to be detrimental, which led to removal of domestic livestock from many lands managed for wildlife (Jourdonnais and Bedunah 1985). Competition between cattle (Bos taurus) and deer (Odocoileus spp.) or elk (Cervus elaphus) is less than once thought (Kingery et al. 1996, Vavra and Sheehy 1996). Previous research has revealed that wild cervids, such as deer and elk, are more selective herbivores than cattle (McMahan 1964, Collins et al. 1978, Kingery et al. 1996). Positive aspects of livestock grazing on wildlife habitat should be addressed. Livestock producers and wildlife managers benefit from this information.

The authors wish to express thanks to the Montana Department of Fish, Wildlife and Parks for their cooperation and assistance in the completion of this project. Research was funded in part by the Montana Agricultural Experiment Station.

Manuscript accepted 13 Jun. 02.

\section{Resumen}

El apacentamiento prescrito del ganado a menudo es usado con el propósito de mejorar el hábitat de la fauna silvestre. En este estudio se investigaron los efectos de la intensidad de apacentamiento en otoño del ganado (Bos taurus) en el forraje disponible para alces (Cervus elaphus) y venados (Odocoileus spp.) en la siguiente primavera y verano. Estos efectos se examinaron en un pastizal de "Rough fescue" (Festuca scabrella Torr.) en el área de Manejo de Fauna Silvestre "Blackfoot Clearwater" localizado en la región central oeste de Montana. El ganado apacentó en exclusiones durante el otoño de 1997 y 1998. Se uso un diseño de bloques completos al azar con 5 repeticiones de exclusión por año. Los niveles de apacentamiento fueron $0 \%$ (control), $50 \%, 70 \%$, y $90 \%$ de remoción de la biomasa en pie. Para evaluar el forraje para el alce y el venado se obtuvieron mediciones en primavera y verano de la biomasa verde en pie de zacates y hierbas, porcentaje de vegetación verde, riqueza de especies y composición de especies vegetales. Los niveles de apacentamiento no mostraron diferencias en la composición de especies de plantas, basado en la cobertura de copa, en la riqueza de especies de plantas y biomasa verde en pie de hierbas $(P>$ 0.10). Los tratamientos de $50 \%$ y $90 \%$ redujeron la biomasa verde en pie en primavera $(P=0.07)$, pero no en verano $(P>$ 0.10). Los tratamientos de apacentamiento incrementaron el porcentaje de vegetación verde $(P<0.01)$. El apacentamiento del ganado en otoño puede ser usado como una herramienta de mejoramiento del hábitat de la fauna silvestre para reducir la biomasa muerta no apetecible. El tratamiento de $70 \%$ de remoción fue el mas favorable para mejorar hábitat sin degradar el pastizal.

Several studies have examined the effects of cattle grazing on winter forage for deer and elk (Anderson and Scherzinger 1975, Neal 1982, Urness 1982, Vavra and Sheehy 1996, Wambolt et al. 1997, Clark et al. 1998). However, there has been little research on how cattle grazing affects spring and summer forage. Spring and summer range is very important for deer and elk production (Collins et al. 1978).

Deer and elk select green grass during spring (Jourdonnais and Bedunah 1985, Lyon 1985). In summer, deer and elk diets consist largely of forbs (McMahan 1964, Stevens 1966, Collins et al. 1978, Kasworm et al. 1984, Jourdonnais and Bedunah 1985, Lyon 1985, Canon et al. 1987, Kingery et al. 1996). Collins et al. (1978) stated that species diversity is an important aspect of wildlife forage. Unpalatable standing dead material is considered a barrier to grazing in bunchgrasses (Willms and McLean 1978, Willms et al. 1979, 1980, 1981, Ruyle et al. 1987, Provenza and 
Table 1. Mean relative utilization and stubble height $( \pm \mathrm{SD})$ of herbaceous standing crop in treated plots. Utilization expressed as percent removed of current standing crop.

\begin{tabular}{lccc}
\hline \hline Year & Target Treatment & Actual Utilization & Stubble Height \\
\hline \multirow{3}{*}{1997} & & $(\%)$ & $(\mathrm{cm})$ \\
& $50 \%$ & $48.9 \pm 2.5$ & $22.2 \pm 3.3$ \\
& $70 \%$ & $70.6 \pm 3.4$ & $11.0 \pm 2.2$ \\
1998 & $90 \%$ & $88.0 \pm 1.4$ & $5.2 \pm 1.6$ \\
& $50 \%$ & $49.4 \pm 2.6$ & $21.5 \pm 3.1$ \\
& $70 \%$ & $69.3 \pm 1.0$ & $12.6 \pm 2.1$ \\
Average & $90 \%$ & $89.2 \pm 1.4$ & $4.0 \pm 1.9$ \\
& $50 \%$ & $49.2 \pm 2.4$ & $21.9 \pm 3.2$ \\
& $70 \%$ & $70.0 \pm 2.4$ & $11.8 \pm 2.3$ \\
& $90 \%$ & $88.6 \pm 1.5$ & $4.6 \pm 2.0$ \\
\hline
\end{tabular}

Balph 1990). When managing spring and summer range, it is important to consider that deer and elk select green grass during spring, forbs during summer, and avoid plants with standing dead material present.

Fall cattle grazing has increased elk use the following spring (Jourdonnais and Bedunah 1990, Frisina 1991). Jourdonnais and Bedunah (1990) recommended that fall cattle grazing be used to make spring forage more attractive for elk. Willms et al. (1979) found that mule deer choose to use fall-grazed areas in the spring. One theory to explain deer and elk preference for areas grazed by cattle in fall by is that fall grazing reduces standing dead material (Willms et al. 1981, Jourdonnais and Bedunah 1985, 1990, Alt et al. 1992). Ungrazed areas accumulate standing dead plant material and stagnant, rank vegetation (Anderson and Scherzinger 1975,
Jourdonnais and Bedunah 1985, 1990). Another theory is that fall cattle grazing increases forb abundance (Stevens 1966). Livestock grazing can increase the amount of forbs for wildlife use (Stevens 1966, found that larger amounts of green growth were present in spring in areas that had been grazed by cattle. However, the effects of fall cattle grazing on deer and elk forage have not been examined in detail. Information on prescribed levels of fall grazing to achieve desired spring and summer forage characteristics is not available. There is a complication of deer and elk preference for areas grazed by livestock in fall. If fall livestock grazing occurs in a rest-rotation grazing system and the fall grazed pasture is rested during the following period of increased deer or elk use, is this increased use due to a change in forage or to the absence of Willms et al. 1979). Willms et al. (1979) domestic livestock and the associated human presence in that pasture?

We hypothesized that larger amounts of green growth, higher forb levels, reduced standing dead material, and/or higher plant diversity are attracting deer and elk to sites previously grazed by cattle. In this study, we describe the impact of fall cattle grazing on spring and summer deer and elk forage. The objectives were to determine if fall cattle grazing improves spring and summer forage for deer and elk, and if so, what grazing intensity is optimum.

\section{Methods}

\section{Study Site}

This study was conducted on the Blackfoot Clearwater Wildlife Management Area (BCWMA), $70 \mathrm{~km}$ northeast of Missoula in west-central Montana $\left(47.0510^{\circ} \mathrm{N}, 113.2726^{\circ} \mathrm{W}\right)$. The Montana Department of Fish, Wildlife, and Parks manages the area for wildlife. Most of the area has been excluded from domestic livestock grazing since 1948 (Baty 1995). Recently, the Montana Department of Fish, Wildlife, and Parks became interested in using cattle grazing as a management tool. Permit grazing was started on portions of the wildlife management area in 1995. Study sites were located on the old Boyd Ranch on the east side of the area. The sites were used by deer and/or elk dur-

Table 2. Effects of forage utilization level in fall on various forage characteristics the following spring and summer.

\begin{tabular}{|c|c|c|c|c|c|c|}
\hline \multirow[b]{2}{*}{ Season } & \multirow[b]{2}{*}{ Forage Variable } & \multirow{2}{*}{$\begin{array}{l}\text { ANOVA } \\
\text { P-value }\end{array}$} & \multicolumn{4}{|c|}{ Treatment Level } \\
\hline & & & $0 \%$ & $50 \%$ & $70 \%$ & $90 \%$ \\
\hline \multirow[t]{3}{*}{$\overline{\text { Spring }}$} & $\begin{array}{l}\text { Green herbaceous } \\
\text { standing crop } \\
\left(\mathrm{g} / \mathrm{m}^{2}\right)\end{array}$ & $P=0.07$ & $88.4 a$ & $75.6 b$ & $78.8 \mathrm{ab}$ & $73.2 b$ \\
\hline & $\begin{array}{l}\text { Green grass } \\
\text { standing crop } \\
\left(\mathrm{g} / \mathrm{m}^{2}\right)\end{array}$ & $\mathrm{P}=0.12$ & 76.0 & 64.0 & 65.6 & 62.4 \\
\hline & $\begin{array}{l}\text { Percent green } \\
\text { vegetation }\end{array}$ & $\mathrm{P}<0.01$ & $49.4 \mathrm{a} 1$ & $82.7 b$ & $92.7 \mathrm{c}$ & $97.7 \mathrm{c}$ \\
\hline \multirow[t]{5}{*}{ Summer } & $\begin{array}{l}\text { Green herbaceous } \\
\text { standing crop } \\
\left(\mathrm{g} / \mathrm{m}^{2}\right)\end{array}$ & $P=0.21$ & 172.4 & 156.4 & 160.4 & 178.8 \\
\hline & $\begin{array}{l}\text { Green forb } \\
\text { standing crop } \\
\left(\mathrm{g} / \mathrm{m}^{2}\right)\end{array}$ & $P=0.83$ & 23.2 & 24.8 & 26.0 & 22.8 \\
\hline & $\begin{array}{l}\text { Percent green } \\
\text { vegetation }\end{array}$ & $\begin{array}{l}19982 \mathrm{P}<0.01 \\
19992 \mathrm{P}<0.01\end{array}$ & $\begin{array}{l}56.1 \mathrm{a} \\
71.2 \mathrm{a}\end{array}$ & $\begin{array}{l}93.7 \mathrm{~b} \\
94.2 \mathrm{~b}\end{array}$ & $\begin{array}{l}95.1 \mathrm{bc} \\
99.0 \mathrm{c}\end{array}$ & $\begin{array}{l}98.2 \mathrm{c} \\
99.9 \mathrm{c}\end{array}$ \\
\hline & $\begin{array}{l}\text { Relative abundance } \\
\text { of rough fescue }\end{array}$ & $P=0.97$ & 59.5 & 59.9 & 61.6 & 59.3 \\
\hline & $\begin{array}{l}\text { Plant species } \\
\text { richness }\end{array}$ & $\mathrm{P}=0.57$ & 17.5 & 17.5 & 18.5 & 19.4 \\
\hline
\end{tabular}


ing spring and summer but not in winter.

Climate of the study area is typical of mountainous regions. Annual precipitation varies from 30 to $75 \mathrm{~cm}$ with a mean of 45 cm (Steele 1981). Winter snow accumulations on summer ranges commonly exceed $100 \mathrm{~cm}$ (Baty 1995). Summers are warm and dry; over $66 \%$ of precipitation falls from December to June. Monthly mean temperatures range from $-8.4^{\circ} \mathrm{C}$ in January to $16.8^{\circ} \mathrm{C}$ in July (Steele 1981).

Weather was variable over the 2 years of the study. Total monthly precipitation and average daily temperatures were noticeably different between the 2 years of the study. The second year had a warmer, wetter winter and a cooler, drier spring than year 1 . The cool, dry spring made year 2 a less productive year for vegetation growth.

The study area consists of a mixture of grasslands and forest on gentle mountainous topography. Elevations range from 1,200 to $1,800 \mathrm{~m}$. Grasslands on the study site are dominated by rough fescue (Festuca scabrella Torr.). Additional common species include Idaho fescue (Festuca idahoensis Elmer), Columbian needlegrass (Stipa columbiana Macoun), Richardson's needlegrass (Stipa richardsonii Link), bluebunch wheatgrass (Agropyron spicatum (Pursh) Gould), timber oatgrass (Danthonia intermedia Vasey), prairie junegrass (Koeleria macrantha Ledeb.), threadleaf sedge (Carex filifolia Nutt.), western yarrow (Achillea millefolium L.), sticky geranium (Geranium viscosissimum F. and M.), and lupine (Lupinus spp. Pursh). Several wildlife management areas across western Montana have similar rough fescue dominated range types (Jourdonnais and Bedunah 1985). Rough fescue is considered excellent forage for deer and elk but accumulates dead plant material when grazing is absent (Jourdonnais and Bedunah 1990).

\section{Study Design}

To study the effects of fall cattle grazing on deer and elk forage, we applied different levels of grazing intensity inside enclosures. The experimental unit was a single 20-m x 20-m plot (0.04 ha). Each plot was fenced individually as a separate enclosure for cattle grazing. In 1997 a total of 20 enclosures were constructed in 5 blocks on the east side of the study area. In 1998 the enclosures were torn down and reconstructed on new ground in the same areas. All 10 blocks were constructed on homogeneous sites within the same range site. Blocks were constructed of 3-strand barbed-wire perimeters and divided into individual enclosures with electric fence. Each block contained 1 control enclosure along with 3

Table 3. Botanical composition $(\%, \pm \mathrm{SD})$ of grazing enclosures based on canopy cover.

\begin{tabular}{|c|c|c|c|c|}
\hline \multirow[b]{2}{*}{ Name } & \multicolumn{4}{|c|}{ Treatment Level } \\
\hline & $0 \%$ & $50 \%$ & $70 \%$ & $90 \%$ \\
\hline Graminoids & \multicolumn{4}{|c|}{$\cdots \cdots-\cdots(\%, \pm$ SD) $\cdots \cdots$} \\
\hline Festuca scabrella Torr. & $59.5 \pm 18.9$ & $59.9 \pm 15.4$ & $61.6 \pm 13.9$ & $59.3 \pm 13.4$ \\
\hline Festuca idahoensis Elmer & $6.3 \pm 8.1$ & $4.5 \pm 6.4$ & $3.8 \pm 5.4$ & $4.2 \pm 6.9$ \\
\hline Stipa columbiana Trin. & $1.4 \pm 2.6$ & $3.8 \pm 7.1$ & $2.7 \pm 4.7$ & $0.8 \pm 1.1$ \\
\hline Stipa richardsonii Link & $1.5 \pm 3.2$ & $1.4 \pm 2.9$ & $2.4 \pm 4.6$ & $1.2 \pm 1.6$ \\
\hline Pseudoroegneria spicata (Pursh) A. Love & $1.1 \pm 2.5$ & $0.6 \pm 1.4$ & $0.1 \pm 0.1$ & $0.8 \pm 2.1$ \\
\hline Phleum pratense $\mathrm{L}$. & $0.5 \pm 1.4$ & $0.1 \pm 0.4$ & $0.3 \pm 0.9$ & $0.9 \pm 1.6$ \\
\hline Danthonia intermedia Vasey & $0.6 \pm 0.7$ & $3.4 \pm 3.6$ & $0.9 \pm 1.9$ & $1.2 \pm 1.2$ \\
\hline Koeleria pyramidata Lam. Beauv. & $0.2 \pm 0.3$ & $0.5 \pm 0.6$ & $0.7 \pm 0.7$ & $1.1 \pm 1.4$ \\
\hline Pascopyrum smithii (Rydb.) A. Love & $0.0 \pm 0.0$ & $0.1 \pm 0.3$ & $0.0 \pm 0.1$ & $0.0 \pm 0.0$ \\
\hline Carex spp. & $4.0 \pm 6.5$ & $5.1 \pm 7.8$ & $5.5 \pm 10.7$ & $5.2 \pm 7.9$ \\
\hline Total graminoids & $75.2 \pm 11.6$ & $79.4 \pm 9.5$ & $78.1 \pm 12.0$ & $74.8 \pm 11.7$ \\
\hline \multicolumn{5}{|l|}{ Forbs } \\
\hline Lupinus spp. & $7.5 \pm 5.9$ & $3.8 \pm 4.1$ & $5.0 \pm 5.7$ & $2.8 \pm 4.2$ \\
\hline Achillea millefolium $\mathrm{L}$. & $2.3 \pm 1.9$ & $3.5 \pm 2.0$ & $3.1 \pm 2.6$ & $3.9 \pm 3.1$ \\
\hline Geranium viscosissimum Fisch \& Meyer & $2.7 \pm 5.4$ & $1.0 \pm 1.5$ & $3.0 \pm 5.8$ & $1.9 \pm 3.0$ \\
\hline Antennaria alpina (L.) Gaertn. & $2.9 \pm 3.8$ & $1.9 \pm 3.0$ & $2.0 \pm 2.6$ & $1.6 \pm 2.5$ \\
\hline Erigeron spp. & $1.2 \pm 1.3$ & $1.0 \pm 1.6$ & $1.2 \pm 1.1$ & $1.5 \pm 2.0$ \\
\hline Potentilla gracilis Dougl. ex Hook & $1.1 \pm 1.3$ & $0.6 \pm 0.6$ & $0.4 \pm 0.4$ & $1.3 \pm 1.2$ \\
\hline Hieracium spp. & $0.9 \pm 1.1$ & $0.5 \pm 0.7$ & $0.7 \pm 0.8$ & $0.4 \pm 0.6$ \\
\hline Fragaria spp. & $0.9 \pm 1.0$ & $0.4 \pm 0.3$ & $0.6 \pm 0.6$ & $0.8 \pm 1.0$ \\
\hline Eriogonum spp. & $0.5 \pm 0.5$ & $1.2 \pm 2.3$ & $0.6 \pm 1.0$ & $0.4 \pm 0.6$ \\
\hline Ambrosia artemisiifolia $\mathrm{L}$. & $0.3 \pm 0.6$ & $0.4 \pm 0.8$ & $0.6 \pm 0.7$ & $0.5 \pm 0.7$ \\
\hline Galium spp. & $0.9 \pm 1.5$ & $0.7 \pm 1.5$ & $0.2 \pm 0.5$ & $0.9 \pm 1.4$ \\
\hline Geum triflorum Pursh & $0.1 \pm 0.3$ & $0.1 \pm 0.3$ & $0.2 \pm 0.4$ & $0.4 \pm 0.7$ \\
\hline Tragopogon dubius Scop. & $0.0 \pm 0.0$ & $0.0 \pm 0.0$ & $0.1 \pm 0.3$ & $0.2 \pm 0.6$ \\
\hline Haplopappus armerioides (Nutt.) Gray & $0.3 \pm 1.0$ & $0.3 \pm 0.4$ & $0.1 \pm 0.2$ & $0.2 \pm 0.5$ \\
\hline Penstemon procerus Dougl. ex Grah. & $0.6 \pm 0.7$ & $0.5 \pm 0.8$ & $0.5 \pm 0.8$ & $1.0 \pm 1.3$ \\
\hline Linaria vulgaris Miller & $0.1 \pm 0.2$ & $0.9 \pm 2.7$ & $0.0 \pm 0.0$ & $0.0 \pm 0.0$ \\
\hline Arenaria spp. & $0.1 \pm 0.1$ & $0.4 \pm 0.7$ & $0.3 \pm 0.9$ & $0.7 \pm 2.1$ \\
\hline Zygadenus spp. & $0.0 \pm 0.1$ & $0.1 \pm 0.1$ & $0.1 \pm 0.2$ & $0.1 \pm 0.1$ \\
\hline Artemisia cana Pursh & $0.0 \pm 0.1$ & $0.2 \pm 0.4$ & $0.5 \pm 1.0$ & $0.5 \pm 0.9$ \\
\hline Campanula rotundifolia $\mathrm{L}$. & $0.0 \pm 0.0$ & $0.1 \pm 0.2$ & $0.2 \pm 0.2$ & $0.2 \pm 0.2$ \\
\hline Silene spp. & $0.0 \pm 0.1$ & $0.0 \pm 0.0$ & $0.1 \pm 0.2$ & $0.0 \pm 0.0$ \\
\hline Antennaria pulcherrima (Hook.) Greene & $0.0 \pm 0.0$ & $0.2 \pm 0.5$ & $0.0 \pm 0.0$ & $0.1 \pm 0.2$ \\
\hline Chrysopsis villosa (Pursh) Shinners & $0.0 \pm 0.1$ & $0.1 \pm 0.2$ & $0.0 \pm 0.0$ & $0.4 \pm 1.2$ \\
\hline Descurainia spp. & $0.0 \pm 0.0$ & $0.0 \pm 0.0$ & $0.0 \pm 0.0$ & $0.1 \pm 0.3$ \\
\hline Centaurea maculosa Lam. & $0.1 \pm 0.1$ & $0.0 \pm 0.0$ & $0.0 \pm 0.0$ & $0.0 \pm 0.0$ \\
\hline Annual forbs & $0.6 \pm 0.6$ & $1.2 \pm 1.3$ & $1.1 \pm 0.9$ & $3.8 \pm 4.0$ \\
\hline Other forbs & $1.8 \pm 2.4$ & $1.6 \pm 2.3$ & $1.1 \pm 1.4$ & $1.6 \pm 2.5$ \\
\hline Total forbs & $24.8 \pm 11.6$ & $20.6 \pm 9.5$ & $21.9 \pm 12.0$ & $25.2 \pm 11.7$ \\
\hline \multicolumn{5}{|l|}{ Other } \\
\hline Bare ground & $1.5 \pm 2.1$ & $3.2 \pm 3.6$ & $4.3 \pm 4.3$ & $4.6 \pm 5.2$ \\
\hline Litter & $26.7 \pm 10.1$ & $31.9 \pm 15.0$ & $33.5 \pm 17.1$ & $27.8 \pm 16.3$ \\
\hline Standing dead & $31.7 \pm 11.2 \mathrm{a} 1$ & $2.4 \pm 2.7 \mathrm{~b}$ & $0.2 \pm 0.4 \mathrm{~b}$ & $0.0 \pm 0.0 \mathrm{~b}$ \\
\hline
\end{tabular}

${ }^{1}$ Means in the same row followed by different letters are significantly different $(\mathrm{P} \leq 0.10)$.

treatment enclosures. Treatments were randomly assigned within blocks.

\section{Treatments}

During mid September in 1997 and 1998, short duration cattle grazing was implemented on the enclosures in the grazing treatment groups. Eight cow/calf pairs were used for each block. When 1 treatment was completed, cattle were moved to the next treatment within that block. Grazing treatments were monitored so grazing could be terminated when grazing target levels were achieved.

In each block, cattle grazed each of 4 enclosures to $50 \%$ relative utilization, $70 \%, 90 \%$, or $0 \%$ (control). Relative utilization is defined as percent removal of current standing crop as opposed to utilization, which is defined as percent removal of current year's growth. These treatments were equivalent to moderate, heavy, severe, and no grazing (Table 1). A pilot study on the Wildlife Management Area conducted in 1995 and 1996 indicated that relative utilization higher than $50 \%$ was needed to prompt any noticeable change in forage. Relative utilization (Frost et al. 1994) in treatment enclosures was measured by the grazed class method (Kingery et al. 1992). Stubble height measurements were taken along with relative utilization measurements (Table 1). Treatments were all applied within a 2week period. Control enclosures were not grazed by domestic ungulates. 


\section{Vegetation Sampling}

Vegetation data was collected during the spring and summer of 1998 and 1999, according to plant phenology. Spring sampling started 3 weeks after initial green up of rough fescue, which occurred in midMay in 1998 and 5 days later in 1999. Summer vegetation measurements were taken at the seed ripening for the majority of herbaceous species, which occurred in late June in 1998 and 10 days later in 1999.

A double sampling procedure was used to estimate weight of standing crop for spring and summer. Weights of green grass, green forbs, and standing dead material were estimated on a dry matter basis for $15,0.25-\mathrm{m}^{2}$ quadrats in each enclosure. Quadrats were placed every 1 meter along 2 transects. Every fifth quadrat estimated was clipped, bagged, oven dried, and weighed on a dry matter basis for calibration of the estimates. Summer standing crop measurements were taken from the opposite side of transects used for spring collection. Linear regression equations were developed from estimated and actual dry weights of clipped plots with $\mathrm{R}^{2}$ values ranging from 0.72 to 0.97 and averaging 0.84 . The equations were used to calibrate estimated dry weights for green forbs, green grass, and standing dead vegetation.

We used the canopy-coverage method (Daubenmire 1959) to measure plant species composition and relative abundance. Species richness was determined by the average number of species found in enclosures during canopy-coverage sampling. Cover measurements were taken during the summer at seed ripening to facilitate plant identification. Each enclosure had 2 additional $10-\mathrm{m}$ transects for cover sampling. A 20 x 50-cm Daubenmire frame was placed every 0.5 meter on alternating sides along the transects to estimate vegetation canopy cover, totaling 40 frames per enclosure.

\section{Statistical Analysis}

Analysis of variance (ANOVA) general linear model was used to test for differences in forage characteristics (SAS 1998). The initial ANOVA model included year, block, treatment, year*treatment interaction, and block*treatment interaction. Non-significant interactions $(\mathrm{P}>$ 0.10 ) were dropped from the final model, however, all main effects were kept in the final model. Least significant difference (LSD) multiple comparison tests $(\mathrm{P} \leq$ 0.10 ) were used to identify statistical differences among treatment levels if the ANOVA was significant.

\section{Results}

\section{Spring Forage}

Total green herbaceous standing crop in spring was affected by treatment level $(\mathrm{P}=$ $0.07)$. The 50 and $90 \%$ treatments resulted in a reduced amount of green standing crop compared to the control and $70 \%$ treatments (Table 2). Green grass standing crop in spring did not differ among treatment groups $(P=0.12)$. Percent green vegetation in spring was affected by treatment $(\mathrm{P}<$ 0.01 ). Percent green vegetation increased as grazing intensity increased (Table 2).

\section{Summer Forage}

Total green herbaceous standing crop in summer (Table 2) did not differ among treatment groups $(\mathrm{P}=0.21)$. Summer forb standing crop also did not differ $(\mathrm{P}=0.83)$ among treatments. A year*treatment interaction $(\mathrm{P}<0.01)$ existed for percent green vegetation in summer. In 1998, percent green vegetation differed among treatments $(\mathrm{P}<0.01)$. The control treatment averaged $56 \%$ green vegetation and average percent green vegetation increased with increased grazing intensity (Table 2). In 1999, percent green vegetation also differed among treatments $(\mathrm{P}<0.01)$. The control treatment averaged $71 \%$ green vegetation, and average percent green vegetation increased with increased grazing intensity (Table 2).

\section{Species Composition}

Relative abundance did not differ among treatments for rough fescue $(\mathrm{P}=$ 0.97 ) or for any other species (Table 3 ). Relative abundance of rough fescue averaged between $59.3 \%$ and $61.6 \%$ (Table 2). Species richness did not differ among treatments $(\mathrm{P}=0.52)$. The average number of species present in each treatment ranged from 17.5 to 19.4 (Table 2). Standing dead material was the only composition variable that differed among treatments $(\mathrm{P}<0.01)$. The control treatment contained a substantially greater canopycoverage of standing dead material than did the grazed treatments (Table 3 ).

\section{Discussion}

Lower green herbaceous standing crop in the spring as a result of 50 and $90 \%$ treatments is unexplained. The difference was of low significance $(P=0.07)$ and likely does not make a large biological difference. There was no effect of treatment level on green grass standing crop in the spring. Since deer and elk select for green grass during spring, treatment levels had no effect on the production of preferred deer and elk forage. It appears that earlier warming of soil in grazed areas was not beneficial enough to increase spring green herbaceous standing crop. Moisture held by residual plant material could have made up for earlier warming of soil. Our study did not, however, measure timing of spring green-up. It is possible that grazed treatments greened-up earlier, due to quicker soil warming, which would be attractive to deer and elk.

The cause of differences in spring standing crop due to grazing intensity apparently did not affect summer production. McLean and Wikeem (1985) and Willms et al. (1986) also found that fall defoliation did not reduce herbage production the following year.

Higher grazing intensities created higher levels of green vegetation in relation to standing dead material. Our findings agree with those of Willms et al. (1979), in which availability of spring forage was related to degree of prior fall grazing by cattle. Willms et al. (1981) reported that deer did not use areas in spring until new growth extended above standing dead material. When standing dead material is removed, preferred green growth is accessible by deer and elk. In a study of spring forage selection by deer, Willms and McLean (1978) found that forage was only utilized from plants where mature stalks had been removed prior to spring growth.

Our findings on green forb standing crop in summer did not support the theory that deer and elk are attracted to sites grazed by cattle the previous fall due to increased forb levels. To increase forb levels with cattle grazing may take several years of treatments, treatments during the growing season and possibly reduction of rough fescue. Since forbs are the preferred forage for deer and elk in the summer (McMahan 1964, Stevens 1966, Collins et al. 1978, Kasworm et al. 1984, Jourdonnais and Bedunah 1985, Lyon 1985, Canon et al. 1987, Kingery et al. 1996), treatment level did not effect the production of preferred deer and elk forage.

During summer, as in spring, the more intense the utilization treatment the higher the percentage of green vegetation. Deer and elk select for forbs in the summer, but the amount of standing dead material present affects whether forbs are available for consumption by a selective forager. The production of forbs and their availability are both important. Through maintaining forb production and increasing their availability, grazing treatments improved summer forage for deer and elk. 
The lack of differences in the number of plant species present and in the relative abundance of plant species present indicates that we did not alter already healthy range sites. The sites meet goals of providing livestock forage in the fall and preferred deer and elk forage in the spring. A change in the number of plant species present or the relative abundance of plant species present may have reduced the site's ability to meet these goals.

\section{Management Implications}

We improved spring and summer forage for deer and elk on our study site. The reduction of unpalatable standing dead material without compromising forage production is possible with fall cattle grazing. The $70 \%$ utilization treatment would be best for improving forage availability. An average $70 \%$ treatment goal on a landscape level would allow ranges in utilization from 50 to $90 \%$. This would increase percent green biomass in both spring and summer, not reduce green grass standing crop in spring, not reduce green forb standing crop in summer, not alter species richness of the sites, and not alter relative abundance of plant species present. By grazing cattle in the fall, managers can utilize the current year's growth for livestock production and deer and elk forage can be more easily accessed.

Treatment areas should be assessed for use by deer and elk in the winter before treatment. It would be inadvisable to apply fall grazing treatments to an area that is valuable winter range.

McLean and Wikeem (1985) found that heavy fall defoliation of rough fescue did not damage plants. Studies in British Columbia and Alberta found that annual yields of rough fescue were not affected after fall defoliation (McLean and Wikeem 1985, Willms et al. 1986). This suggests that high levels of fall cattle grazing may improve availability of elk and deer forage without damaging or reducing yield of rough fescue plants. However, it is important to monitor the status of rough fescue stands due to their high value for wildlife. McLean and Wikeem (1985) indicated that fall use followed by heavy spring use could damage rough fescue plants. High deer and elk use in the spring could degrade the range and require a change in management. Treated areas should be monitored to determine if the range is being degraded. It is possible that over time, treatments could reduce rough fescue proportional abundance.

Information from this study could be incorporated into rest-rotation or deferred- rotation grazing systems. Pastures recognized as spring and summer range for elk and deer and not winter range, could be grazed to an average of $70 \%$ relative utilization during their fall rotation. This would improve availability of forage in those pastures for deer and elk during the year following treatment.

\section{Literature Cited}

Alt, K.L., M.R. Frisina, and F.J. King. 1992. Coordinated management of elk and cattle, a perspective-Wall Creek Wildlife Management Area. Rangelands 14:12-15

Anderson, W.E. and R.J. Scherzinger. 1975. Improving quality of winter forage for elk by cattle grazing. J. Range Manage. 28:120-125.

Baty, G.R. 1995. Resource partitioning and browse use by sympatric elk, mule deer and white-tailed deer on a winter range in western Montana. M.S. Thesis, Univ. Montana, Missoula, Mont.

Canon, S.K., P.J. Urness, and N.V. DeByle. 1987. Habitat selection, foraging behavior, and dietary nutrition of elk in burned aspen forest. J. Range Manage. 40:433-437.

Clark, P.E., W.C. Krueger, L.D. Bryant, and D.R. Thomas. 1998. Spring defoliation effects on bluebunch wheatgrass: I. Winter forage quality. J. Range Manage. 51:519-525.

Collins, U.J., P.J. Urness, and D.D. Austin. 1978. Elk diets and activities on different lodgepole pine habitat segments. J. Wildl. Manage. 42:799-810.

Daubenmire, R. 1959. A canopy-coverage method of vegetational analysis. Northwest Sci. 33:43-64.

Frisina, M.R. 1991. Elk habitat use within a rest-rotation grazing system. Rangelands. 14:93-96.

Frost, W.E., E.L. Smith, and P.R. Ogden. 1994. Utilization guidelines. Rangelands. 16:256-259.

Jourdonnais, C.S. and D.J. Bedunah. 1985. Improved elk forage: range research along the Sun River. Western Wildl. Spring:20-24.

Jourdonnais, C.S. and D.J. Bedunah. 1990. Prescribed fire and cattle grazing on an elk winter range in Montana. Wildl. Soc. Bull. 18:232-240.

Kasworm, W.F., L.R. Irby, and H.B. Ihsle Pac. 1984. Diets of ungulates using winter ranges in northcentral Montana. J. Range Manage. 37:67-71.

Kingery, J.L., C. Boyd, and P.E. Kingery. 1992. The grazed-class method to estimate forage utilization on transitory forest rangelands. Univ. of Idaho For., Wildl, and Range Exp. Sta. Bull. 54, Moscow, Ida.

Kingery, J.L., J.C. Mosley, and K.C. Bordwell. 1996. Dietary overlap among cattle and cervids in northern Idaho forests. J. Range. Manage. 49:8-15.

Lyon, J.L. 1985. Elk and cattle on the national forests: a simple question of allocation or a complex management problem. Western Wildl. Spring:16-19.
McLean, A. and S. Wikeem. 1985. Rough fescue response to season and intensity of defoliation. J. Range Manage. 38:100-103.

McMahan, C.A. 1964. Comparative food habits of deer and three classes of livestock. J. Wildl. Manage. 28:798-808.

Neal, D.L. 1982. Improvement of Great Basin deer winter range with livestock grazing, $\mathrm{p}$. 61-73. In: J.M. Peek and P.O. Dalke (ed.), Proc. Wildlife-Livestock Ralationships Symp. Univ. of Idaho For., Wildl. and Range Exp. Sta., Moscow, Ida.

Provenza, F.D. and D.F. Balph. 1990. Applicability of five diet-selection models to various foraging challenges ruminants encounter, p. 423-459. In: R.N. Hughes (ed.), Behav. Mech. of Food Selection. Springer-Verlag, Berlin.

Ruyle, G.B., O. Hasson, and R.W. Rice. 1987. The influence of residual stems on biting rates of cattle grazing Eragrostis lehmanniana Nees. Appl. Anim. Behav. Sci. 19:11-17.

SAS. 1998. SAS/STAT user's guide. 7.0 ed. SAS Institute Inc. Cary, N.C.

Steele, R.W. 1981. Weather data summary 1957-1980. Lubrecht Experimental Forest, Greenough, Montana. Mont. Forest and Conserv. Exp. Sta. Misc. Pap. 13. School of Forest., Univ. Montana, Missoula, Mont.

Stevens, D.R. 1966. Range relationships of elk and livestock, Crow Creek drainage, Montana. J. Wildl. Manage. 30:349-363.

Urness, P.J. 1982. Livestock as tools for managing big game winter range in the Intermountain West, p. 20-30. In: J.M. Peek and P.O. Dalke (ed.), Proc. WildlifeLivestock Relationships Symp. Univ. of Idaho Forest., Wildl. and Range Exp. Sta., Moscow, Ida.

Vavra, M. and D. Sheehy. 1996. Improving elk habitat characteristics with livestock grazing. Rangelands 18:182-185.

Wambolt, C.L., M.R. Frisina, K.S. Douglass, and H.W. Sherwood. 1997. Grazing effects on nutritional quality of bluebunch wheatgrass for elk. J. Range Manage. 50:503-506.

Willms, W. and A. McLean. 1978. Spring forage selection by tame mule deer on big sagebrush range, British Columbia. J. Range Manage. 31:192-199.

Willms, W., A.W. Bailey, and A. McLean. 1980. Effect of burning or clipping Agropyron spicatum in the autumn on the spring foraging behaviour of mule deer and cattle. J. Appl. Ecol. 17:69-84.

Willms, W., S. Smoliak, and A.W. Bailey. 1986. Herbage production following litter removal on Alberta native grasslands. J. Range Manage. 39:536-540.

Willms, W., A.W. Bailey, A. McLean, and R. Tucker. 1981. The effects of fall defoliation on the utilization of bluebunch wheatgrass and its influence on the distribution of deer in spring. J. Range Manage. 34:16-18.

Willms, W., A. McLean, R. Tucker, and R. Ritchey. 1979. Interactions between mule deer and cattle on big sagebrush range in British Columbia. J. Range Manage. 32:299-304. 


\title{
Economic and environmental impacts of pasture nutrient management
}

\author{
EDWARD OSEI, PHILIP W. GASSMAN, LARRY M. HAUCK, SUSAN NEITSCH, RON D. JONES, JAN MCNITT, \\ AND HEATHER JONES
}

Authors are Senior Research Economist, Texas Institute for Applied Environmental Research (TIAER), Tarleton State University, Stephenville, Tex, 76402, Research Agricultural Engineer, Center for Agricultural and Rural Development, Iowa State University, Ames, Iowa 50011, Assistant Director, TIAER, Research Asssociate, Spatial Sciences Laboratory - Texas A\&M University, College Station, Tex 77843, Director, TIAER, Worker Advocate, State of Maine, Portland, Maine 04101, and Senior Research Assistant, TIAER.

\begin{abstract}
Highly intensive stocking of dairy cattle on continuously grazed pasture coupled with liberal applications of commercial fertilizer can lead to increased losses of agricultural nutrients, which is a concern for water quality of receiving lakes and surface water resources. Integrated economic-environmental model simulations performed for the Lake Fork Reservoir Watershed in northeast Texas indicate that appropriate pasture nutrient management including stocking density adjustments and more efficient commercial fertilizer use could lead to significant reductions in nutrient losses. Soluble and organic $P$ losses were predicted to decline by 54 and $13 \%$ relative to baseline conditions when manure $P$ was assumed totally plant available (Low $P$ scenario). The soluble and organic $P$ loss reductions declined to 33 and $7 \%$ when only inorganic $P$ was assumed plant available (High $\mathbf{P}$ scenario). Simulation of an $\mathrm{N}$-based manure management plan resulted in the smallest predicted soluble and organic $P$ loss reductions of 18 and $3 \%$. Nitrogen loss predictions ranged from a $7 \%$ decline to a $1 \%$ increase for the 3 scenarios as compared to the baseline. The High $P$ and Low $P$ scenarios resulted in estimated aggregate profit reductions of 6 and $18 \%$ relative to the baseline. These profit declines occurred because the dairies had to acquire additional pasture land to accommodate the expanded area required for the P-based scenarios. In contrast, the $\mathbf{N}$-based stocking density and nutrient management scenario resulted in an aggregate profit increase of $3 \%$ across all dairies. Variations in economic impacts were also predicted across farm sizes.
\end{abstract}

Key Words: Stocking density, manure, nutrient losses, nitrogen, phosphorus, economics

Concerns over adverse water quality impacts associated with livestock production have increased dramatically over the past few decades. Much of this concern is due to concentration of livestock production in relatively small areas or specific watersheds, resulting in problems such as increased nitrogen $(\mathrm{N})$ and

The authors acknowledge support from the U.S. Environmental Protection Agency (USEPA) which provided funding for the project under Contract No. CR 820384-02-7. The views expressed in this paper are not necessarily those of the USEPA.

Manuscript accepted 13 Jul. 02.

\section{Resumen}

La carga altamente intensiva de ganado lechero en praderas apacentadas continuamente, acompañado con aplicaciones abundantes de fertilizante comercial pueden conducir a un aumento de perdida de los nutrientes agrícolas, lo cual es una preocupación para la calidad del agua de los lagos receptores y los recursos de agua superficial. Simulaciones de un modelo integral ambiental-económico realizadas para la cuenca hidrológica del Lago Fork en el noreste de Texas indican que el manejo apropiado de los nutrientes de la pradera, incluyendo ajustes en la densidad de carga animal y el uso de fertilizantes comerciales más eficientes, pudiera conducir a reducciones significantes en las perdidas de nutrientes. Se predijo que las perdidas de $P$ soluble $y$ orgánico disminuirían en 54 y $13 \%$ en relación a las condiciones iniciales, esto cuando se asumio que el $\mathbf{P}$ del estiércol era totalmente disponible para las plantas (escenario de baja disponibilidad de $\mathbf{P}$ ). La reducción de las perdidas de $\mathbf{P}$ soluble y orgánico disminuyó a 33 y $7 \%$ cuando se asumió que solo $P$ inorgánico estaba disponible para las plantas (escenario de alta disponibilidad de P). La simulación de un plan de manejo de estiércol basado en $\mathbf{N}$ resulto en las reducciones más pequeñas de perdida de $P$ soluble e inorgánico, 18 y $3 \%$. Las predicciones de perdida de $\mathrm{N}$ variaron de $7 \%$ de disminución a $1 \%$ de incremento, esto para los 3 esenarios y comparando con el contenido inicial. Los escenarios de $P$ alto y bajo resultaron en reducciones estimadas de la ganancia agregada del 6 y $18 \%$ en relación al contenido inicial. Estas disminuciones de la ganancia ocurrió porque las lecherías tienen que adquirir terrenos de pradera adicionales para proveer el área expandida necesaria para los escenarios basados en $P$. En contraste, el escenario de la densidad de carga animal y el manejo de nutrientes basados en $\mathbf{N}$ resulto en un incremento de la ganancia agregada del $3 \%$ a través de todas las lecherías. Variaciones en el impacto económico fueron también predichas a través de todos los tamaños de granjas.

phosphorus (P) loads in surface water from land-applied manure. Various studies have been performed to evaluate environmental problems related to livestock production (e.g. Dietz and Hoogervorst 1991 - the Netherlands, Hamilton and Sims 1995 the southern portion of Delaware, Warrick and Leavenworth 1996 - the Neuse River Watershed in North Carolina, and McFarland and Hauck 1999 - the Upper North Bosque River Watershed (UNBRW) in north central Texas). 
A National Pilot Project (NPP) on Livestock and the Environment was initiated in 1992 to help provide solutions regarding environmental problems associated with livestock manure management (Jones et al. 1993). A major development of the NPP is the Comprehensive Economic and Environmental Optimization Tool - Livestock and Poultry (CEEOT-LP), an integrated modeling system designed to generate economic and environmental indicators for different scenarios encompassing alternative manure processing technologies, variations in rates and modes of landapplied manure and commercial fertilizer, and other best management practices. The initial application of the modeling system was for a range of policy scenarios focused on manure management in the upper north Bosque river watershed as described by Pratt et al. (1997) and Osei et al. (2000b).

To evaluate implications of various management practices on dairy pasture operations, the modeling system was next applied to pasture-based dairy operations located in the Lake Fork Reservoir Watershed (LFRW) in northeast Texas (McNitt et al. 1999). In livestock agriculture, most nonpoint sources of excessive nitrogen and phosphorus loads have been attributed to confined animal feeding operations whereas pasture-based operations have received relatively minor attention. However, Bottcher et al. (1995) estimated that significant nutrient losses would occur from grazed pastures with high animal densities in the Lake Okeechobee region of Florida, based on various monitoring results and unpublished computer simulations. In a review of several studies, Correll (1996) found that pastures managed with high levels of exogenous nutrients and high animal densities could seriously impact the quality of surface waters. Belsky et al. (1999), in an extensive review, also report that water quality impacts from livestock grazing have been documented across the United States. The objective of this study was to evaluate the economic and environmental impacts of alternative pasture stocking densities and appropriate commercial fertilizer supplementation based on conditions prevailing in the Lake Fork reservoir watershed.

In light of the existing literature, it was hypothesized that low stocking densities and reduced commercial fertilizer supplementation on pastures would lead to a decline in nutrient losses. However, these would also have economic implications to producers due to expected per hectare yield declines and the need to obtain larger pasture area for grazing livestock. To obtain quantitative estimates of these impacts, the following questions were posed:

1. How much change in $\mathrm{N}$ and $\mathrm{P}$ losses would result from typically suggested pasture nutrient management standards (including stocking density adjustments and commercial fertilizer reductions)?

2. What economic impacts to producers are associated with these standards?

\section{The Lake Fork Reservoir Watershed}

The Lake Fork Reservoir Watershed (LFRW) drains portions of Hopkins, Hunt, Rains, and Wood counties in northeast Texas (Fig. 1). The 127,000 ha watershed

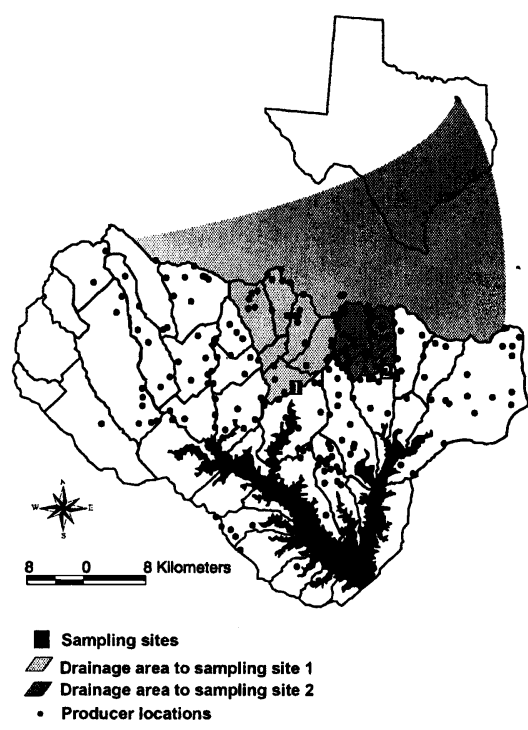

Fig. 1. The Lake Fork Reservoir Watershed (LFRW) with locations of dairy operations, sampling sites, SWAT subbasins, and the reservoir.

contains an 11,210 ha lake that is used primarily for fishing and water supply. Since the early 1990s substantial work done as part of the Lake Fork Creek Hydrologic Unit Area (LFCHUA) project, a cooperative interagency project initiated in the study area, has resulted in improvements in water quality (LFCHUA 1995). As part of the Hydrologic Unit Area project, water quality measurements were taken in the watershed, which showed elevated levels of $\mathrm{N}$ and $\mathrm{P}$ in some of the tributaries of the Lake Fork Reservoir (LFCHUA 1995). The key problems encountered and addressed within the Hydrologic Unit Area project involved pasture denudation and over-fertilization of pastures from manure and commercial fertilizer sources.

A total of 205 dairies with a combined herd size of 26,855 cows were located in the watershed at the time of this study. The majority of the dairies lie within Hopkins County, the second highest milkproducing county in Texas. The vast majority of the dairies in the watershed utilize pasture-based production systems that require confinement of the milking cows only when they are milked. Pasture management consisting of open access grazing $(\mathrm{OAG})$ is used in which cows continuously graze bermuda grass overseeded with winter annuals, primarily winter wheat, rye grass and/or clover. Because pastures are not managed intensively, significant denudation was observed on these grazing operations prior to initiation of the Hydrologic Unit Area project. Pasture management practices that eliminate denudation were shown by McNitt et al. (1999) to generally result in significant reductions in nutrient losses for the watershed. Pasture-based beef production and cow-calf operations that raise calves for slaughter or for replacement of milking cows on dairies are also prevalent in the watershed. Manure deposition and commercial fertilizer applications were both sources of nutrients to the improved pastures used by the beef and dairy operations.

Approximately $71 \%$ of the watershed land area was used for pasture in 1996, with about $44 \%$ classified as improved and the remaining 27\% defined as unimproved (Ewer and Easterling 1998). Forest and brush cover almost $8 \%$ of the remaining land area; less than $2 \%$ of the land area was devoted to cropland. Most of the land is characterized by deep, loamy to sandy soils that are slowly permeable and well drained. Average annual temperature and precipitation are $10^{\circ} \mathrm{C}$ and $1,118 \mathrm{~mm}$.

\section{Model Framework and Simulation Methodology}

Alternative stocking density scenarios for the watershed were performed in a whole-farm manner through an interface of the economic and environmental components within the modeling system (Fig. 2). The Farm-level Economic Model (FEM) is a representative farm model (Osei et al. 2000a) that is used to simulate farm-level economic impacts in response to different policy scenarios. The environmental component consists of 2 models, the field-level Agricultural Policy/Environmental eXtender (APEX) model (Williams et al. 


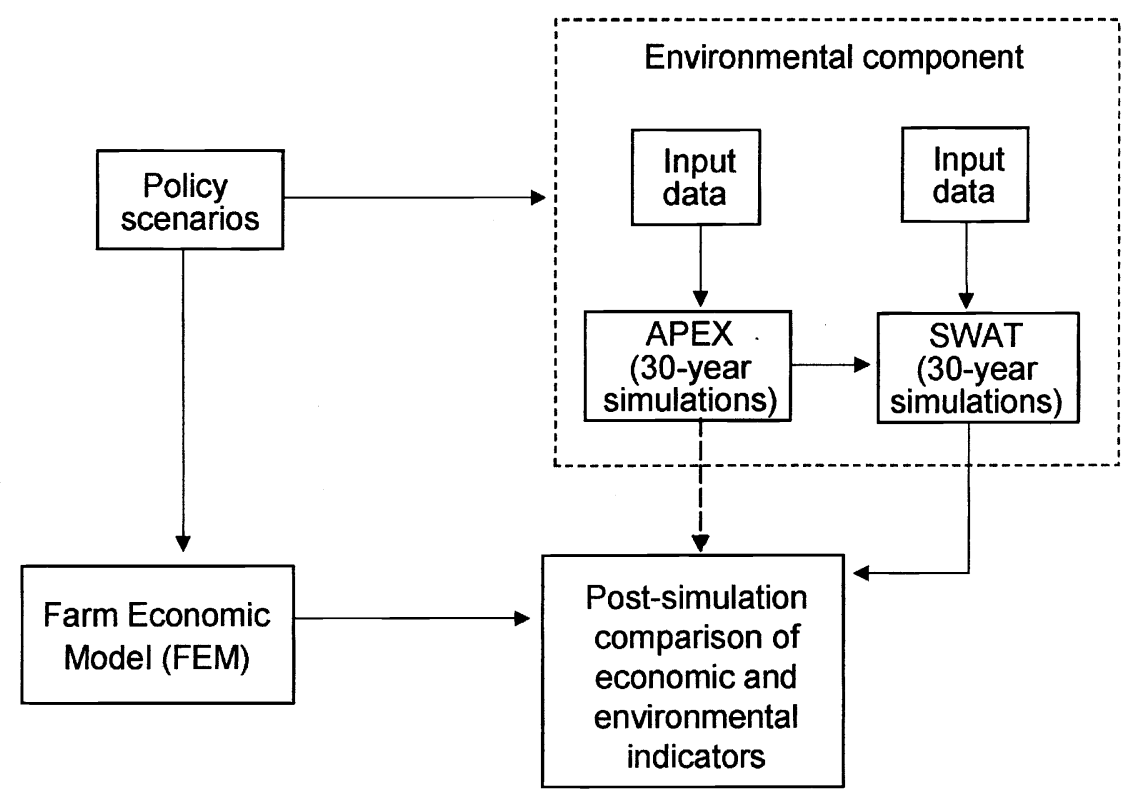

Fig. 2. Schematic of key data flows between models used in the Comprehensive Economic and Environmental Optimization Tool-Livestock and Poultry (CEEOT-LP) modeling system.
1995, 2000) and the watershed-level Soil and Water Assessment Tool (SWAT) model (Arnold et al. 1998). The APEX model is a modified version of the Erosion Productivity Impact Calculator (EPIC) model (Williams 1990, 1995) that is used in the modeling system to simulate alternative management scenarios such as variations in manure and fertilizer application agement practices (BMPs). Edge-of-field sediment and nutrient losses simulated in APEX, coupled with losses simulated in the SWAT model from other land uses, are routed in SWAT through the stream system to the watershed outlet. Watershedlevel indicators from SWAT were used in this study to assess the environmental impacts of the simulated scenarios. However, APEX edge-of-field indicators can also be used in conjunction with, or instead of, the SWAT indicators (Fig. 2).

The economic model operates on annual time step and can be executed for extendgories of input data required to simulate a farm in the economic model include type of livestock system, manure management methods, cropping systems, facilities and equipment, field characteristics, and other external factors. Economic outputs generated by the model include total revenue, total cost, net returns, livestock rations, sales, costs of individual production components (crop and livestock, fertilizer, labor, etc.), debt payment, and owner's equity. rates, and adoption of structural best maned periods of 30 years or more. Key cate-
Economic model simulations were performed for 4 representative dairy operations, 1 for each of 4 size categories constructed to help evaluate the impacts of the scenarios across dairies of different size (Table 1). Dairy farm categories and representative sizes were based on data listing the financial profile of dairies in Hopkins County, Tex. (McDonald 1995). Representative sizes (Table 1) were 95 cows for very small dairies ( $<100$ cows), 178 cows for small dairies (101 to 200 cows), 275 cows for medium sized dairies (201 to 300 cows), and 556 cows for large dairies (> 300 cows). Land area for each dairy was assumed to consist of both pasture and hayland (Table 1). Other charac- teristics related to cull cows, heifers, and land area for the representative dairies are also listed in Table 1.

The edge-of-field model operates on a daily time step and can be applied for a wide range of soil, landscape, climate, crop rotation, and management practice combinations. It can be executed for a single field or used for a wide range of multifield configurations including whole farms, small watersheds, or filter strip impacts on nutrient losses from waste application fields. The main edge-of-field model components are weather, hydrology, soil temperature, erosion-sedimentation, nutrient cycling, tillage, management practices, crop management and growth, and pesticide and nutrient fate and transport. Choice of simulated cropping system, manure and/or fertilizer nutrient characteristics, tillage practices, soil layer properties, and other characteristics are input for each simulated subarea. Key outputs include crop yields, edge-of-field nutrient and sediment losses, and other water and nutrient balance indicators.

All 205 dairies were simulated directly in the edge-of-field model instead of using the economic model representative farms. Dairies were categorized into one of the 4 groups listed in Table 1, based on herd size. Specific pasture and hay field areas could not be obtained for the majority of dairies; however, mean pasture and hay field areas were provided by the Texas State Soil and Water Conservation Board (TSSWCB) for each of the 4 dairy categories. Thus, the pasture and hay field areas simulated for each dairy were determined as a function of the mean herd size, pasture areas, and hay field areas for the respective category. Further description of
Table 1. Herd sizes and other characteristics of the representative watershed dairies simulated in the economic model.

\begin{tabular}{lcrrr}
\hline \hline & Very Small & Small & Medium & Large \\
\hline Herd size range & $<100$ & $101-200$ & $201-300$ & $>300$ \\
Herd size (lactating and dry cows) & 95 & 178 & 275 & 556 \\
Cows culled annually & 24 & 46 & 82 & 160 \\
Replacement heifers purchased annually & 0 & 15 & 15 & 172 \\
Replacement heifers raised annually & 30 & 40 & 84 & 5 \\
Replacement heifers and calves on farm & 60 & 80 & 168 & 10 \\
Total land area per cow (ha) & 0.34 & 0.34 & 0.34 & 0.27 \\
Hay and cropland area per cow (ha) & 0.06 & 0.05 & 0.06 & 0.08 \\
Heifer pasture area per cow (ha) & 0.13 & 0.09 & 0.13 & 0.00 \\
Lactating and dry cow area per cow (ha) & 0.15 & 0.20 & 0.16 & 0.18 \\
Baseline (current) pasture stocking density $\left(\mathrm{cows} \mathrm{ha}^{-1}\right)$ & 6.4 & 5.2 & 6.4 & 5.4 \\
Coastal/wheat agronomic N requirement $\left(\mathrm{kg} \mathrm{ha}^{-1}\right)$ & 336 & 336 & 336 & 336 \\
Coastal/wheat agronomic P requirement $\left(\mathrm{kg} \mathrm{ha}^{-1}\right)$ & 54 & 54 & 54 & 54 \\
Average milk yield (kg/cow/year) & 6717 & 6822 & 7916 & 7602 \\
\hline
\end{tabular}

Source: The information in this table was based on extensive data from the study area. 
the watershed edge-of-field model methodology is given in Osei et al. (2000a).

The Soil and Water Assessment Tool was developed to simulate continuoustime streamflow with a high level of spatial detail by allowing the division of a watershed or river basin into grid cells or sub-watersheds. The model operates on a daily time step and is designed to evaluate management effects on water quality, sediment, and agricultural chemical yield in large, ungaged basins. The major components of the watershed-scale model include hydrology, weather, sedimentation, soil temperature, crop growth, nutrients, pesticides, and agricultural management. The Soil and Water Assessment Tool inputs and outputs are similar to those used in the edge-of-field model.

The remaining land that was not simulated in the edge-of-field model was simulated in the watershed-scale model, and this constituted the majority of the watershed land area. Unimproved pasture was simulated as rangeland in the watershedscale model. Improved pasture, woodland, urban, and the reservoir were the other simulated land use categories. The rangeland and improved pasture were assumed grazed by beef cattle according to the stocking rates described by Bailey and Riggs (1996). Simulated N and P application rates via manure deposition and inorganic fertilizer on pastures and rangeland grazed by beef cattle were also based on values reported by Bailey and Riggs (1996). Point source N and P loadings to tributaries of the Lake Fork Reservoir from 4 waste treatment facilities were accounted for in the watershed model. The total $\mathrm{N}$ and $\mathrm{P}$ loads calculated for the baseline and alternative scenarios were the sum of $\mathrm{N}$ and $\mathrm{P}$ loadings contributed by 7 different tributaries that drain into the reservoir.

\section{Edge-of-field and Economic Model assumptions}

It was estimated that a typical milking cow in the watershed produces $127 \mathrm{~kg} \mathrm{~N}$ and $27 \mathrm{~kg} \mathrm{P}$ annually in manure based on ASAE standards (ASAE 1995). These estimates were based on the mean plus 1 standard deviation of the ASAE values, following customary practice in formulating dairy waste management plans in the study area. Assuming that the percentage of manure deposited on pasture is directly proportional to amount of time spent there, about $88 \%$ of manure nutrient is deposited on pasture and the remainder is collected from the milking parlor and applied on fields designated for liquid waste. This assumption is based on extensive data in the study area which indicates that cows are confined for milking 3 hours each day and turned out on pasture for the remainder of the day (TNRCC various years).

Appropriate manure application rates or stocking densities are based on plant available manure nutrients rather than total manure nutrient production because of various losses and transformations that occur prior to plant uptake. Two adjustments were incorporated in the simulation of manure nitrogen deposited on pasture in order to estimate the proportion that was available for plant uptake. First, it was assumed that $20 \%$ of the manure $\mathrm{N}$ would volatilize from the soil surface, based on permitting guidelines used by the Texas Natural Resource Conservation Commission (TRNCC) as described by Flowers et al. (1998). Second, only $50 \%$ of the remaining manure $\mathrm{N}$ was assumed to be plant available within the first year after direct deposition on pasture, again following local guidelines (Flowers et al. 1998).

Subsequent mineralization of the $\mathrm{N}$ applied in the manure will release additional plant available $\mathrm{N}$ within the soil in the years following deposition (USDA 1979, Flowers et al. 1998). Ideally, this additional $\mathrm{N}$ should be factored into decisions as to the amount of manure $\mathrm{N}$ that would be applied to the same pastures in future depositions. However, a conservative assumption was made that it would be impracticable for producers to keep track of such processes due to inadequate soil testing or irregular use of soil test results. Thus it was assumed that only $50 \%$ of manure $\mathrm{N}$ remaining in the soil profile after volatilization would be considered plant available in every year. No losses were assumed for manure phosphorus or commercial fertilizer nutrients.

Heifers were included in the economic model simulations mainly for cost accounting purposes. The percentage of the overall watershed manure load that would be attributed to the heifer portions of the dairy herds is about $20 \%$. Heifer grazing was not simulated in the edge-offield model, and none of the scenarios discussed in this paper had any impact on heifer pasture area. However, the heifer manure load was indirectly accounted for in the watershed-scale model, because all of the remaining watershed pasture land (including the heifer pasture areas) was assumed to receive beef cattle manure deposition. Although the manure characteristics and stocking rates differ between the 2 species, simulated beef cattle manure depositions accounted for the heifer herd manure loads.

Baseline stocking densities assumed for the dairies varied depending on pasture area available and whether or not a significant portion of pasture was devoted to raising replacement heifers (Table 1). Most large dairies devote a greater portion of land to hay fields than smaller dairies, but they also raise fewer replacement heifers. Baseline lactating and dry cow stocking density was estimated by first subtracting hay area from the total land area, then allocating 0.2 ha of pasture for each replacement heifer raised on the farm. The remaining area was divided by the number of lactating and dry cows to obtain baseline stocking densities (Table 1). The number of replacement heifers raised was based on typical culling practices, death losses, and replacement heifer purchases recorded in dairy farm financial profiles for Hopkins County, Tex. (McDonald 1995) and from communications with watershed experts. The resulting average baseline stocking density across the 4 dairy sizes was about 5.7 cows per hectare (Table 2). This stocking density was corroborated by various experts in the study area who had indicated during independent consultations that stocking densities on dairy pasture in the watershed range from 5 to 7.5 cows per hectare.

The stocking rate of 5.7 cows per hectare results in a total manure $\mathrm{N}$ rate of $624 \mathrm{~kg} \mathrm{ha}^{-1}$ and a corresponding manure plant available nitrogen rate of $250 \mathrm{~kg} \mathrm{ha}^{-1}$ (Table 2). The associated total manure $\mathrm{P}$ and mineral $P$ rates were 135 and $88 \mathrm{~kg}$ $\mathrm{ha}^{-1}$. It was further assumed for the baseline that producers applied about $247 \mathrm{~kg} \mathrm{~N}$ and about $146 \mathrm{~kg} \mathrm{P}_{2} \mathrm{O}_{5}$ (59 kg P) per hectare of pasture each year (Table 2), based again on the judgement of local experts. These application rates were also corroborated by fertilizer cost estimates in dairy farm financial profiles (McDonald $1995)$ as well as fertilizer sales figures for the 4-county region (Office of the State Chemist 1996). Thus the total plant available nitrogen going on pasture each year from manure and commercial fertilizer sources was about 1.5 times the agronomic rate (Table 2).

\section{Additional Economic Model Assumptions}

The scenarios simulated entail various rates of manure and commercial fertilizer nutrients on pasture. To account effectively for economic impacts of these scenar- 
ios, some yield adjustments were made in the economic model to reflect different forage yield responses to manure and commercial fertilizer nutrients. Yield responses were estimated using nitrogen rather than phosphorus application rates. Using information from the study area, it was estimated that commercial fertilizer $\mathrm{N}$ response for Coastal Bermuda grass was $40 \mathrm{~kg}$ dry matter yield/kg N. After further calculations, manure nitrogen yield response was determined to be $24 \mathrm{~kg}$ dry matter yield per $\mathrm{kg}$ of manure plant available nitrogen for Bermuda grass. For winter wheat pasture, about $10 \mathrm{~kg}$ dry matter yield per $\mathrm{kg}$ of nitrogen was assumed for commercial fertilizer $\mathrm{N}$ as well as plant available manure N. Lower yield responses are generally anticipated from manure deposited on pasture than from commercial fertilizer because: (1) manure is deposited unevenly, and (2) trampling of pasture grasses by cattle under open access grazing conditions also stifles forage growth. However, the same winter wheat yield responses were used for manure and commercial fertilizer because the only available information did not suggest higher wheat yield responses from commercial fertilizer (Brown, B. 1997. Personal communication. Texas A\&M University System Extension. Sulphur Springs, Tex.).

In spite of these pasture forage yield adjustments, stocking densities and fertilizer application rates were based on baseline yields to reflect realistic producer behavior since it is impracticable that most producers would estimate yield adjustments in advance and modify application rates accordingly. It was important to mimic actual producer behavior to obtain good estimates of the scenario impacts.

Economic modeling accounted for greater forage availability and uptake by cows when total pasture forage production is increased. However, the model did not assume a proportional decrease in feed costs. This is because larger pasture forage production means that cattle would consume more coastal and wheat forage, necessitating adjustments in purchase of supplemental feed for the herd. The model includes a comprehensive livestock nutrition component that mimics the way producers (and their nutritionists) determine livestock rations. Based on typical milk yields in the study area (ranging from about $6,700 \mathrm{~kg}$ to $7,900 \mathrm{~kg}$ per cow annually for the 4 dairy groups), over $50 \%$ of dry matter intake of lactating cows is from supplemental feed, which is provided in feed troughs placed on the pasture. In extreme cases of overabundant pasture and hay forage production some forage raised on hay fields might be sold.

A two-step General Algebraic Modeling System (GAMS) process (Brooke et al. 1992) was used to estimate purchased feed cost and how much forage, if any, is sold. First, a feed cost minimization process was performed assuming that any unused forage from hay fields or pasture would be sold at a "price" (shadow value) lower than the selling price. During the second step of the process, the unused forage was assumed sold at the selling price rather than the shadow value with adjustments made for marketing expenses. For the watershed simulations, the shadow value for pasture forage was estimated to be $\$ 0$ per ton based on model calibrations. In other words, dairy producers in the watershed would use as much pasture and hay field forage as they can on the dairy, and only sell what the cows cannot consume.

\section{Alternative Pasture Nutrient Management Scenarios}

The first pasture nutrient management alternative simulated for the watershed was performed by setting the stocking density to 7.7 cows ha ${ }^{-1}$, resulting in a manure plant available nitrogen rate of $336 \mathrm{~kg} \mathrm{ha}^{-1}$ that is equal to the nitrogen agronomic requirement of the forage (Table 2). Thus it was assumed that the $\mathrm{N}$ needs of the pasture forage were completely met by manure $\mathrm{N}$, eliminating the need for supplemental $\mathrm{N}$ fertilizer applications. The $\mathrm{N}$ rate scenario also resulted in correspondingly higher inorganic $\mathrm{P}$ and total manure $\mathrm{P}$ application rates that were 2.2 and 3.3 times greater than the agro-

Table 2. Key characteristics of alternative pasture management scenarios ${ }^{\mathrm{a}}$.

\begin{tabular}{|c|c|c|c|c|}
\hline Scenario & Baseline & $\mathrm{N}$ & High P & Low $P$ \\
\hline Average stocking density (cows ha ${ }^{-1}$ ) & 5.7 & 7.7 & 3.5 & 2.2 \\
\hline Commercial fertilizer $\mathrm{N}$ rate $\left(\mathrm{kg} \mathrm{ha}^{-1}\right)$ & 247 & 0 & 182 & 235 \\
\hline Commercial fertilizer $\mathrm{P}$ rate $\left(\mathrm{kg} \mathrm{ha}^{-1}\right)$ & 59 & 0 & 0 & 0 \\
\hline Manure PAN ${ }^{\mathrm{b}}$ rate $\left(\mathrm{kg} \mathrm{ha}^{-1}\right)$ & 250 & 336 & 155 & 100 \\
\hline Total manure $\mathrm{N}$ rate $\left(\mathrm{kg} \mathrm{ha}^{-1}\right)$ & 625 & 841 & 386 & 251 \\
\hline Manure inorganic- $\mathrm{P}$ rate $\left(\mathrm{kg} \mathrm{ha}^{-1}\right)$ & 88 & 118 & 54 & 35 \\
\hline Total manure $\mathrm{P}$ rate $\left(\mathrm{kg} \mathrm{ha}^{-1}\right)$ & 135 & 182 & 84 & 54 \\
\hline Estimated coastal yield ( $\mathrm{kg}$ dry matter $\left.\mathrm{ha}^{-1}\right)$ & 6,390 & 3,767 & 4,372 & 4,562 \\
\hline Estimated wheat yield (kg dry matter ha $\left.{ }^{-1}\right)$ & 3,020 & 1,872 & 2,063 & 2,119 \\
\hline Ratio of total PAN to agronomic $\mathrm{N}$ requirement & 1.5 & 1.0 & 1.0 & 1.0 \\
\hline Ratio of total $\mathrm{N}$ to agronomic $\mathrm{N}$ requirement & 2.6 & 2.5 & 1.7 & 1.4 \\
\hline Ratio of total inorganic- $\mathrm{P}$ to agronomic $\mathrm{P}$ requirement & 2.7 & 2.2 & 1.0 & 0.7 \\
\hline Ratio of total $\mathrm{P}$ to agronomic $\mathrm{P}$ requirement & 3.6 & 3.3 & 1.5 & 1.0 \\
\hline
\end{tabular}

Source: The data in this table was computed from extensive information from the Lake Fork reservoir watershed. ${ }^{a}$ All fertilizer and manure application rates simulated on an annual basis

${ }^{\mathrm{b}} \mathrm{PAN}=$ plant available nitrogen nomic $\mathrm{P}$ rate of the crop (Table 2). Again, supplemental $\mathrm{P}$ fertilizer was not required for this scenario, because the crop uptake requirements for $\mathrm{P}$ were more than satisfied by manure $P$.

Two alternative P-based stocking density scenarios were also simulated for the watershed, defined as "High P" and "Low $\mathrm{P}$ ". These scenarios reflected prevailing opinions about how P-based nutrient management plans should be designed. The High $\mathrm{P}$ stocking density scenario assumes that the organic (particulate) component of manure $\mathrm{P}$ is not readily available for plant uptake resulting in the inorganic $\mathrm{P}$ portion in the manure being deposited at a rate equivalent to forage agronomic $P$ requirements. The calculated High $P$ stocking rate of 3.5 cows ha ${ }^{-1}$ results in manure inorganic $\mathrm{P}$ and total $\mathrm{P}$ deposition rates of 54 and $84 \mathrm{~kg} \mathrm{ha}^{-1}$, and associated manure plant available nitrogen and total $\mathrm{N}$ application rates of 155 and $386 \mathrm{~kg} \mathrm{ha}^{-1}$ (Table 2). Due to the disparity between the N/P ratio of manure nutrients and that of forage required at a rate of $182 \mathrm{~kg} \mathrm{ha}^{-1}$ to meet the forage agronomic $\mathrm{N}$ requirements.

The Low P option assumes a stocking density and commercial nutrient application such that manure total $\mathrm{P}$ supplies all forage $\mathrm{P}$ needs. The resulting stocking rate was estimated to be 2.2 cows ha ${ }^{-1}$, with corresponding manure inorganic and total $\mathrm{P}$ deposition rates of 35 and $54 \mathrm{~kg} \mathrm{ha}^{-1}$ (Table 2). In this case, an even higher commercial fertilizer $\mathrm{N}$ rate of $235 \mathrm{~kg} \mathrm{ha}^{-1}$ was simulated to meet the agronomic $\mathrm{N}$ requirements of the pasture forage. The Low P scenario entails the least stocking density and consequently the greatest pasture area requirement. requirements, commercial fertilizer $\mathrm{N}$ was 
Table 3. Mean values of key measured and simulated water quality indicators for the Lake Fork reservoir watershed.

\begin{tabular}{lcccc}
\hline \hline Indicator & Site $^{1}$ & Number of observations $^{2}$ & Measured $^{3}$ & Simulated $^{3}$ \\
\hline Flow $\left(\mathrm{m}^{3} \mathrm{sec}^{-1}\right)$ & 1 & 133 & 0.67 & 0.73 \\
$\mathrm{NO}_{3}\left(\mathrm{mg} \mathrm{liter}^{-1}\right)$ & 2 & 31 & 2.46 & 2.93 \\
Soluble P $\left(\mathrm{mg} \mathrm{liter}^{-1}\right)$ & 2 & 32 & 0.27 & 0.44 \\
Total P $\left(\mathrm{mg} \mathrm{liter}^{-1}\right)$ & 2 & 32 & 0.67 & 0.47 \\
Sediment $\left(\mathrm{mg} \mathrm{liter}^{-1}\right)$ & 2 & 30 & 112 & 64 \\
\hline
\end{tabular}

${ }^{1}$ See Figure 1 for location of sites 1 and 2.

${ }^{2}$ Monthly streamflow values were measured between September 1978 and September 1989 at site 1; nutrient and sediment measurements were performed between 12 April, 1994 and 11 November, 1996.

${ }^{3}$ Standard deviations reported for the observed and simulated flows were 0.875 and 0.703 ; standard deviations were not reported for the other indicators.
Consistent with scenario specifications, alternative stocking densities and associated supplemental commercial $\mathrm{N}$ fertilizer rates were simulated in the economic model for the lactating and dry cow pastures but not for the heifer pastures. Other assumptions were held at baseline specifications. The stocking density simulated for the $\mathrm{N}$ scenario is actually higher than the stocking density assumed for the baseline, which suggests that open access grazing operations in the watershed generally have adequate land to manage pasture nutrients according to forage $\mathrm{N}$ requirements. Forage $\mathrm{N}$ needs were being exceeded in the baseline because of commercial fertilizer rates used on pasture. Producers could, therefore, alternatively reduce commercial fertilizer rates, maintain current stocking densities, and still achieve reasonable pasture nutrient management regarding forage $\mathrm{N}$ requirements.

The P-based scenarios require additional pasture area that is currently not owned or farmed by dairies. Thus moving to the $\mathrm{P}$ scenarios may present logistical problems in some cases. Based on land availability and farming practices in the study area, it was assumed that dairy producers would purchase rather than lease additional land when they need to increase pasture area beyond existing levels.

\section{Results and Discussions}

\section{Model Testing}

Testing of the environmental models for watershed baseline conditions built upon previous testing of the models for the Upper North Bosque River watershed, in which edge-of-field output was compared with flow, sediment, and nutrient runoff losses at the edge of 8 field plots (Flowers et al. 1996) and watershed-scale model output (that incorporated edge-of-field loadings) was compared with in-stream observations of flow, sediment, and nutri- ents (Saleh et al. 2000). Monitoring data available for the Lake Fork reservoir watershed was relatively sparse, consisting of in-stream flow measurements at 1 site and in-stream sediment and nutrient observations at 5 other sites ( 3 of which were only monitored for 9 days). Watershedscale model predictions, that included edge-of-field loadings from dairy pastures and hayfields, were compared with flow measurements at sampling site 1 (Fig. 1) for a 10-year period and with sediment and nutrient measurements at sampling site 2 (Fig. 1) for slightly more than 2.5 years (the site with the longest record of in-stream sediment and nutrient observations). Predicted mean values for flow and other indicators compared favorably with observed means (Table 3 ), with the greatest difference resulting for sediment which was underpredicted by $50 \%$. Further description of the model comparisons with measured data is provided by S. Neitsch, (1998. Unpublished research data,
Blackland Research Center, Temple, Tex.).

The economic model was also calibrated for the watershed using data pertaining to Hopkins County, which encompasses more than half of the watershed. Comparisons of simulated and actual values for some economic indicators are given in Table 4 . The results indicate that economic model estimates of various indicators were reasonably close to measured values. Calibration results are reflective of Hopkins County dairy conditions, rather than the entire watershed. Thus scenario baseline results differ somewhat, as expected, from the calibration output.

\section{Scenario Results}

Environmental model simulations were performed for 30 years using daily precipitation, maximum temperature, and minimum temperature data obtained for Sulphur Springs, Texas and other nearby weather stations. Other required weather inputs were generated internally in the environmental models.

Figure 3 shows watershed-scale 30-year average annual baseline loadings, and the resulting impacts of the 3 stocking density scenarios relative to the baseline, for key sediment and nutrient indicators. The cant reductions in nutrient losses are attainable under all 3 alternative scenarios relative to the baseline. With the exception of $\mathrm{N}$ losses for the Low $\mathrm{P}$ rate, adopting pasture nutrient management based on forage $\mathrm{N}$ or $\mathrm{P}$ needs results unambiguously in results indicate that moderate to signifi-

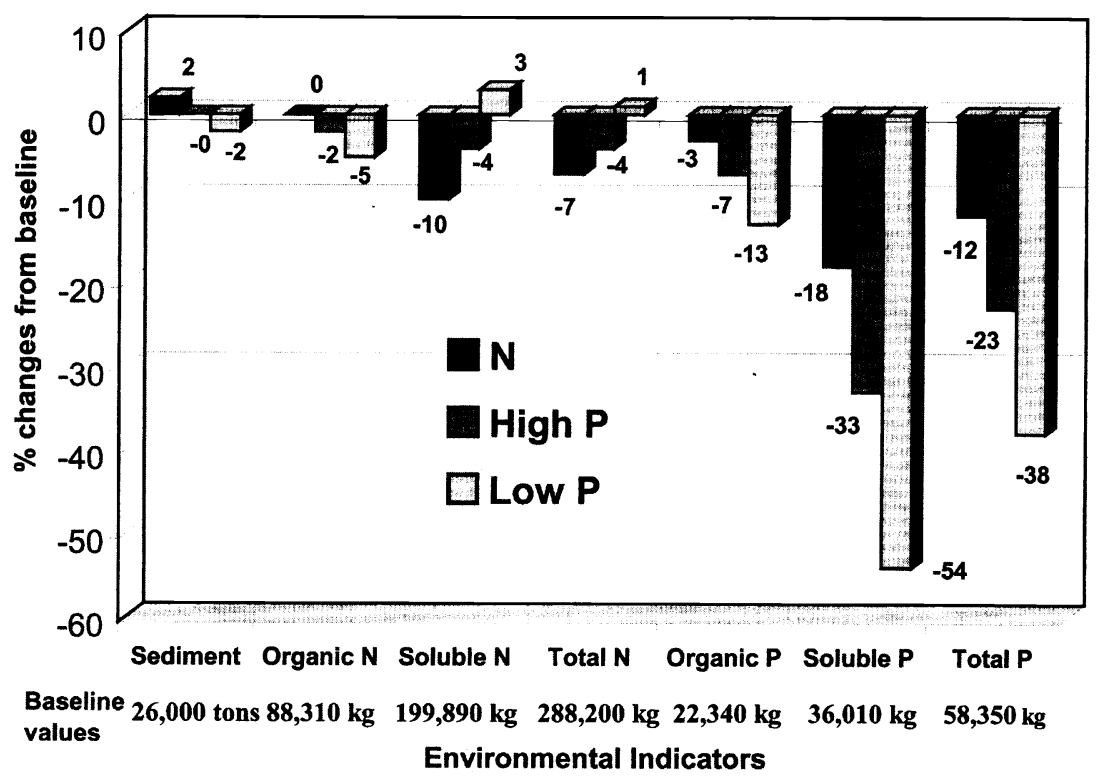

Fig. 3. Environmental impacts: \% changes from baseline values. 
Table 4. Comparison of measured and simulated values for various economic indicators.

\begin{tabular}{|c|c|c|c|c|c|}
\hline Indicator & $\begin{array}{l}\text { Measured vs. } \\
\text { Simulated }\end{array}$ & Very small & Small & Medium & Large \\
\hline Total Revenue & $\begin{array}{l}\text { Measured } \\
\text { Simulated }\end{array}$ & $\begin{array}{l}204,050 \\
204,050\end{array}$ & $\begin{array}{l}408,883 \\
408,883\end{array}$ & $\begin{array}{l}787,041 \\
787,041\end{array}$ & $\begin{array}{l}1,403,862 \\
1,403,862\end{array}$ \\
\hline Feed Cost & $\begin{array}{l}\text { Measured } \\
\text { Simulated }\end{array}$ & $\begin{array}{l}79,829 \\
76,249\end{array}$ & $\begin{array}{l}167,297 \\
159,737\end{array}$ & $\begin{array}{l}408,882 \\
397,559\end{array}$ & $\begin{array}{l}502,128 \\
482,347\end{array}$ \\
\hline Other Costs & $\begin{array}{l}\text { Measured } \\
\text { Simulated }\end{array}$ & $\begin{array}{l}84,205 \\
85,207\end{array}$ & $\begin{array}{l}173,801 \\
178,143\end{array}$ & $\begin{array}{l}278,343 \\
277,849\end{array}$ & $\begin{array}{l}663,787 \\
642,335\end{array}$ \\
\hline Total Costs & $\begin{array}{l}\text { Measured } \\
\text { Simulated }\end{array}$ & $\begin{array}{l}164,034 \\
161,455\end{array}$ & $\begin{array}{l}341,098 \\
337,880\end{array}$ & $\begin{array}{l}687,225 \\
675,408\end{array}$ & $\begin{array}{l}1,165,915 \\
1,124,681\end{array}$ \\
\hline Net Returns & $\begin{array}{l}\text { Measured } \\
\text { Simulated }\end{array}$ & $\begin{array}{l}40,016 \\
42,595\end{array}$ & $\begin{array}{l}67,785 \\
71,003\end{array}$ & $\begin{array}{r}99,816 \\
111,633\end{array}$ & $\begin{array}{l}237,947 \\
279,181\end{array}$ \\
\hline
\end{tabular}

improved water quality benefits. Because the current stocking density is between the $\mathrm{N}$ and High $\mathrm{P}$ stocking densities, this suggests that producers only need to apply commercial fertilizer at lower rates than they do now to obtain a 4 to $7 \%$ reduction in total $\mathrm{N}$ loads and 12 to $23 \%$ reduction in total $\mathrm{P}$ loads at the watershed level. Edge-of-field reductions from the dairy pastures would be even higher.

Economic impacts estimated using the economic model are shown in Figure 4, which shows baseline net returns to unpaid labor and management for each dairy group and at the aggregate watershed level, and the percentage changes in net returns that occur when the stocking density scenarios are imposed. The watershed aggregate impacts were obtained as a weighted sum of the individual dairy effects using the number of dairies in each group as the weighting factor. Results presented in Figure 4 indicate that most dairies can benefit financially by shrinking pasture sizes slightly to accommodate forage $\mathrm{N}$ requirements with plant available manure $\mathrm{N}$ only and eliminating all commercial fertilizer sources. At the watershed-level, dairy profits increase by almost $3 \%$ in response to the $\mathrm{N}$-based stocking density scenario.

Contrary to the N-based scenario, the Pbased pasture nutrient management alternatives are costly. The High and Low $\mathrm{P}$ alternatives would cost producers 6 and $18 \%$ of current profits in aggregate, respectively. Table 5 shows various cost components and other indicators for all scenarios. In spite of the expanded area, total fertilizer cost is lower for all dairies under the High $\mathrm{P}$ scenario relative to the baseline. On the other hand, notwithstanding the increased pasture area total feed cost is no less under the High P scenario than the baseline, primarily because total forage production is slightly less due to much lower per hectare forage yield. The available, whereas all of the land required when moving from the High P scenario to the Low P scenario has to be purchased. Furthermore, fertilizer costs are higher with the Low P option, and purchased feed costs do not decline in a manner proportionate with pasture forage consumption. The latter results from the assumption that dairy producers would strive to maintain milk yields, which imposes various constraints on feed ration formulation. Thus the Low P scenario results in significantly greater cost to dairy producers than the High P option.

Finally, the economic impacts across dairy size groups are also significant (Fig. 4 and Table 5). This result suggests that, where possible, it may be socially optimal to give producers some latitude in choosing a set of options that would enable them to meet environmental criteria in a performance-based program. This latitude would result in a substantial decrease in the cost of nutrient loss reduction due primarily to the beneficial impacts of accounting for spatial variability across the grazing operations.

\section{Cost-effectiveness estimates for $\mathbf{P}$ loss reduction}

All 3 alternative scenarios presented above reduce total $\mathrm{P}$ loads relative to the baseline. While the Low P alternative provides the best prospect for $\mathrm{P}$ loss reduction, it can also lead to an increase in soluble $\mathrm{N}$ loads. The choice among these scenarios may also depend upon costs to dairy producers. Cost effectiveness estimates provide a uniform basis for comparison in

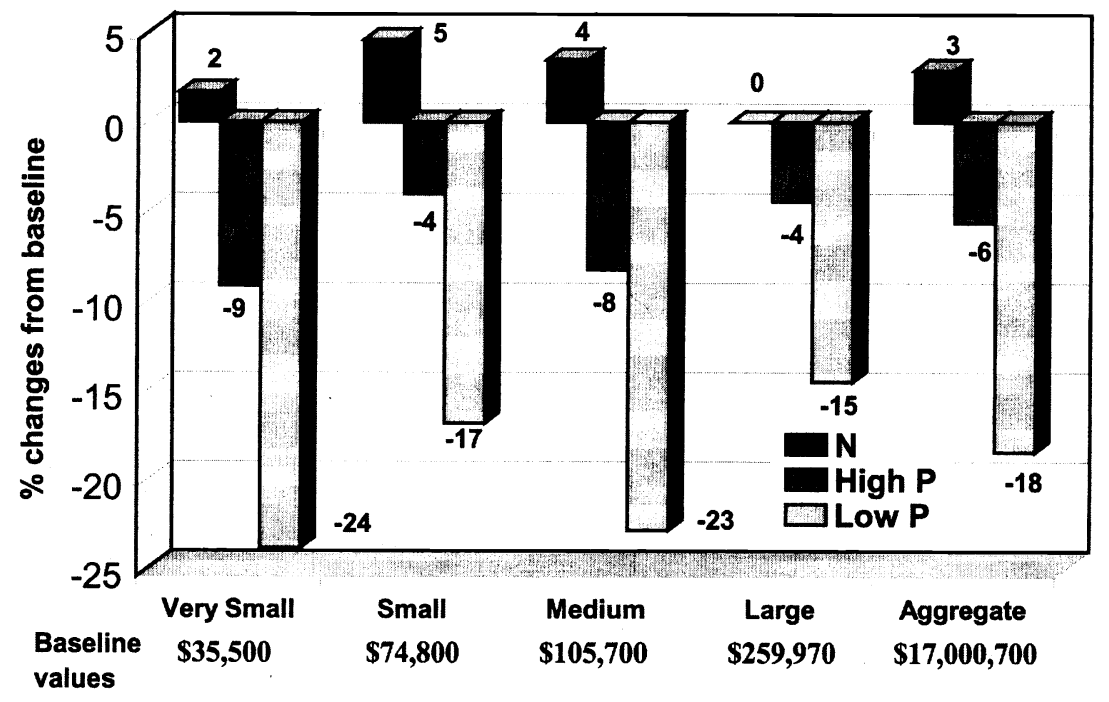

Fig. 4. Economic impacts: $\%$ changes in net returns from baseline values. 
Table 5. Summary land use and economic impacts of alternative pasture stocking densities ${ }^{\mathrm{a}}$.

\begin{tabular}{|c|c|c|c|c|c|c|c|c|c|c|c|c|c|}
\hline \multirow[b]{2}{*}{$\begin{array}{l}\text { Scenarios By } \\
\text { Farm Size }\end{array}$} & \multicolumn{3}{|c|}{----Land Area---- } & \multirow[b]{2}{*}{$\begin{array}{l}\text { Stocking } \\
\text { Density }\end{array}$} & \multirow{2}{*}{\multicolumn{2}{|c|}{$\begin{array}{c}\text { Additional Land } \\
\text { Purchased } \\
\text { Annual }\end{array}$}} & \multirow[b]{2}{*}{ Fertilizer } & \multicolumn{3}{|c|}{ 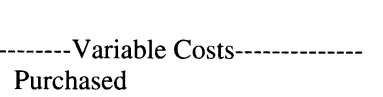 } & \multirow[b]{2}{*}{$\begin{array}{l}\text { Fixed } \\
\text { Costs }\end{array}$} & \multirow[b]{2}{*}{ Revenue } & \multirow[b]{2}{*}{$\begin{array}{c}\text { Net } \\
\text { Returns }^{b}\end{array}$} \\
\hline & Total & Hay & Pasture & & & $\begin{array}{c}\text { Annual } \\
\text { Cost }\end{array}$ & & $\begin{array}{c}\text { Purchase } \\
\text { Feed }\end{array}$ & Other & Total & & & \\
\hline Very Small & \multicolumn{3}{|c|}{ 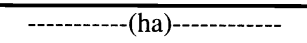 } & (cows/ha) & (ha) & $(\$ /$ farm) & & & \$/farm) --. & ----- & $(\$ /$ farm $)$ & $(\$ /$ farm $)$ & (\$/farm) \\
\hline Baseline & 32 & 5 & 27 & 6.4 & 0 & 0 & 9,200 & 69,000 & 62,200 & 140,500 & 30,900 & 206,900 & 35,500 \\
\hline $\mathrm{N}$ & 32 & 7 & 25 & 7.7 & 0 & 0 & 6,000 & 71,400 & 62,200 & 139,600 & 31,200 & 206,900 & 36,100 \\
\hline High P & 43 & 3 & 39 & 3.5 & 11 & 1,900 & 8,400 & 69,700 & 63,800 & 141,900 & 32,700 & 206,900 & 32,300 \\
\hline Low P & 57 & 3 & 54 & 2.2 & 26 & 4,400 & 12,700 & 65,300 & 66,300 & 144,300 & 35,500 & 206,900 & 27,100 \\
\hline \multicolumn{14}{|l|}{ Small } \\
\hline Baseline & 60 & 9 & 51 & 5.2 & 0 & 0 & 17,400 & 128,800 & 107,600 & 253,700 & 66,900 & 395,400 & 74,800 \\
\hline $\mathrm{N}$ & 60 & 20 & 40 & 7.7 & 0 & 0 & 12,400 & 128,300 & 108,200 & 248,900 & 68,300 & 395,400 & 78,200 \\
\hline High P & 74 & 6 & 67 & 3.5 & 14 & 2,300 & 13,900 & 131,200 & 109,500 & 254,600 & 69,000 & 395,400 & 71,800 \\
\hline Low P & 101 & 6 & 95 & 2.2 & 41 & 7,000 & 21,900 & 122,800 & 114,100 & 258,900 & 74,300 & 395,400 & 62,300 \\
\hline \multicolumn{14}{|l|}{ Medium } \\
\hline Baseline & 93 & 15 & 77 & 6.4 & 0 & 0 & 26,700 & 332,400 & 182,100 & 541,200 & 96,900 & 743,800 & 105,700 \\
\hline $\mathrm{N}$ & 93 & 23 & 70 & 7.7 & 0 & 0 & 17,600 & 336,700 & 182,300 & 536,600 & 97,800 & 743,800 & 109,400 \\
\hline High P & 123 & 10 & 113 & 3.5 & 30 & 5,100 & 24,100 & 334,400 & 186,600 & 545,000 & 101,800 & 743,800 & 97,000 \\
\hline Low P & 165 & 10 & 155 & 2.2 & 72 & 12,300 & 36,400 & 321,700 & 194,000 & 552,100 & 110,100 & 743,800 & 81,600 \\
\hline \multicolumn{14}{|l|}{ Large } \\
\hline Baseline & 150 & 46 & 104 & 5.4 & 0 & 0 & 45,900 & 406,600 & 346,200 & 798,700 & 324,700 & $1,383,400$ & 260,000 \\
\hline $\mathrm{N}$ & 150 & 74 & 75 & 7.7 & 0 & 0 & 30,000 & 418,400 & 350,400 & 798,800 & 324,500 & $1,383,400$ & 260,000 \\
\hline High P & 181 & 20 & 162 & 3.5 & 32 & 5,400 & 29,500 & 428,300 & 346,400 & 804,200 & 330,600 & $1,383,400$ & 248,600 \\
\hline Low $\mathrm{P}$ & 267 & 20 & 247 & 2.2 & 117 & 20,200 & 54,400 & 398,300 & 362,100 & 814,900 & 346,100 & $1,383,400$ & 222,400 \\
\hline
\end{tabular}

${ }^{\mathrm{a}}$ Dollar values have been rounded off to nearest hundreds.

${ }^{\mathrm{b}} \mathrm{S}$ cenarios with higher net returns than baseline value indicate net financial benefit relative to the baseline, and vice versa.

such situations. These coefficients represent the unit cost of pollutant reduction, for example, the unit cost of $\mathrm{P}$ load reduction.

Model simulation results were used to obtain cost-effectiveness coefficients for $\mathrm{P}$ load reduction as $-\$ 69, \$ 70$, and $\$ 140$ per $\mathrm{kg}$ of total $\mathrm{P}$ load reduced for the $\mathrm{N}$, High $\mathrm{P}$, and Low $\mathrm{P}$ scenarios. That is, for every $\mathrm{kg}$ of $\mathrm{P}$ reduced, producers would save $\$ 69$ if the $\mathrm{N}$ scenario is used, they would lose $\$ 70$ if the High $P$ alternative is in place, and they would incur a $\$ 140$ cost if the Low P option is used. These results do not mean, however, that the $\mathrm{N}$ scenario is necessarily the "best" alternative. It means that within limits of acceptable error, if no more than $12 \%$ reduction in aggregate $P$ loads at the watershed level is desired, the $\mathrm{N}$ scenario might be the most reasonable option because it achieves a roughly $12 \%$ reduction in aggregate $\mathrm{P}$ loads and producers obtain a profit increase, a win-win situation. However, the $\mathrm{N}$ scenario will not accomplish environmental objectives, if a $P$ load reduction target much greater than $12 \%$ is desired. It may be useful in some cases to target different scenarios to various producers, depending on spatial variability in economic and environmental impact potential, as other studies have also shown (e.g. Carpentier et al. 1998, VanDyke et al. 1999).

\section{Summary and Conclusions}

Many watersheds draining areas of intensive livestock farming have experienced varying degrees of water quality impairment due to nutrient enrichment from manure and commercial fertilizer applications. In the Lake Fork Reservoir Watershed (LFRW) of Texas, water quality measurements taken as part of a Hydrologic Unit Area project indicated elevated levels of $\mathrm{N}$ and $\mathrm{P}$ in tributary streams. Upland areas draining into the lake are predominantly characterized by dairy and beef cattle grazing operations that also apply commercial fertilizer on pasture. The Hydrologic Unit Area project indicated that highly intensive stocking of cattle on continuously grazed pasture may be partly responsible for excessive nitrogen and phosphorus loads to the lake and that appropriate stocking density management could reduce nutrient losses from dairy pasture. In this paper, results of computer model simulations performed to evaluate pasture nutrient management alternatives for the watershed were presented.

Pasture stocking densities were adjusted to conform to forage nutrient uptake requirements. In addition, commercial fertilizer rates on pasture were modified so that the combined rate of manure and commercial fertilizer nutrients applied to pastures was consistent with forage needs. Computer simulations using a comprehen- sive suite of models indicated that appropriate pasture nutrient management does have potential for nutrient loss reduction, particularly for phosphorus, which is typically the nutrient of primary concern regarding eutrophication of lakes. Economic results indicated varying impacts across dairy sizes and across the N, High P, and Low P pasture nutrient management alternatives. Whereas the nitrogen-based option would entail slight profit increases to producers (an aggregate profit increase of 3\%), the Pbased rates would result in moderate to significant cost increases (from 6 to $18 \%$ decline in profits on aggregate).

The choice of which alternative to use in a given situation depends on how much nutrient reduction is required. For instance, if total $\mathrm{P}$ loss reduction is the desired objective, the least costly alternative in this case is also the least effective. Within a performance-based water quality management program, a portfolio of options might be the best approach, with latitude for producers to choose which options best suit their operations.

\section{Literature Cited}

Arnold, J.G., R. Srinivasan, R.S. Muttiah, and J. R. Williams. 1998. Large area hydrologic modeling and assessment; Part I: model development. J. Amer. Water Res. Assoc. 34(1):73-89. 
ASAE. 1995. American Society of Agricultural Engineers. Manure production and characteristics. ASAE Data: ASAE D384.1 AFPC.

Bailey, K.L. and D.W. Riggs. 1996. A National Pilot Project: Livestock and the Environment - Nutrient Budget Analysis for the Lake Fork Reservoir Watershed. Project Report PR9608. Texas Instit. Appl. Environ.Res., Tarleton State Univ., Stephenville, Tex.

Belsky, A.J., A. Matzke, and S. Uselman. 1999. Survey of livestock influences on stream and riparian ecosystems in the western United States. J. Soil Water Conserv. First Quarter 1999:419-431.

Bottcher, AB., T.K. Tremwel, and K.L. Campbell. 1995. Best management practices for water quality improvement in the Lake Okeechobee watershed. Ecol. Eng. 5(1995):341-356.

Brooke, A., D. Kendrick, and A. Meeraus. 1992. GAMS: A User's Guide, Release 2.25 Washington, D.C.: World Bank.

Carpentier, C.L., D.J. Bosch, and S.S. Batie. 1998. Using spatial information to reduce costs of controlling agricultural nonpoint source pollution. Agr. Resource Econ. Rev. April 1998:72-84.

Correll, D.L. 1996. Environmental impacts of pasture systems on surface water quality. In: Nutrient Cycling in Forage Systems (R.E. Joost and C.A. Roberts, Ed.). Potash \& Phosphate Inst. and the Found. Agron. Res., Manhattan, Kans.

Dietz, FJ. and N. J.P. Hoogervorst. 1991. Towards a sustainable and efficient use of manure in agriculture: the Dutch case. Environ. Resource Econ. 1:313-332.

Ewer, S. and N. Easterling. 1998. Lake Fork Reservoir Watershed and Running Creek Sub-Watershed Geographic Information System Data Report. Report WP9805. Texas Inst. Appl. Environ. Res., Tarleton State Univ., Stephenville, Tex.

Flowers, J.D., J.R. Williams, and L.M. Hauck. 1996. NPP Integrated Modeling System: Calibration of the APEX Model for Dairy Waste Application Fields in Erath County, Texas. PR 96-07, Texas Inst Appl. Environ. Res., Tarleton State Univ., Stephenville, Tex.
Flowers, J.D., E. Osei, L.M. Hauck, P.W. Gassman, and A.M.S. McFarland. 1998 Livestock and the environment, a national pilot project: manure nutrient application rates and other assumptions underlying APEX runs. TIAER Information Bull. 98-03. Texas Inst. Appl. Environ. Res., Tarleton State Univ., Stephenville, Tex.

Hamilton, C.M. and J.T. Sims. 1995. Nitrogen and phosphorus availability in enriched, pelletized poultry litters. J. Sustainable Agr. 5(3):115-132.

Jones, R., L. Frarey, A. Bouzaher, S. Johnson, and S. Neibergs. 1993. Livestock and the Environment: A National Pilot Project; Detailed Problem Statement. Texas Inst. Appl Environ. Res. Stephenville, Tex. 1993.

LFCHUA 1995. Lake Fork Creek Hydrologic Unit Area Project. Ann. Project Rep. Fiscal Year 1995.

McDonald, R. 1995. Hopkins County Dairy Profile. Prepared for: Texas Inst. for Appl. Environ. Res., Stephenville, Tex, September 1995.

McFarland, A.M.S. and L.M. Hauck. 1999. Relating agricultural land uses to in-stream stormwater quality. J. Environ. Qual. 28(3):836-844.

McNitt, J., R. Jones, E. Osei, L. Hauck, and H. Jones. 1999. Livestock and the Environment: precedents for runoff policy policy option-CEEOT-LP. Report PR9909. Texas Inst. Appl. Environ. Res., Tarleton State Univ., Stephenville, Tex

Office of the State Chemist. 1996. Annual Report on Commercial Fertilizers. Texas Feed and Fertilizer Control Service, 1981-1995.

Osei, E., P. Gassman, and A. Saleh. 2000a. Livestock and the Environment: a national pilot project; Economic and environmental modeling using CEEOT. Report PR0002. Texas Inst. Appl. Environ. Res., Tarleton State Univ., Stephenville, Tex.

Osei, E., P. W. Gassman, R. D. Jones, S. J. Pratt, L. M. Hauck, L. J. Beran, W. D. Rosenthal, and J. R. Williams. 2000b. Economic and environmental impacts of alternative practices on dairy farms in an agricultural watershed. J. Soil Water Conserv. 55 (4):466-472.
Pratt, S., R. Jones, and C.A. Jones, 1997. Livestock and the environment: Expanding the focus: Policy options: CEEOT-LP, Texas Inst. Appl. Environ. Res., Tarleton State Univ., Stephenville, Tex.

Saleh A., J. G. Arnold, P. W. Gassman, L. M. Hauck, W. D. Rosenthal, J. R. Williams, and A.M.S. McFarland. 2000. Application of SWAT for the Upper North Bosque River Watershed. Trans. ASAE 45(3):1077-1087.

TNRCC. Various years. Dairy waste management plans. On file. Texas Nat. Resource Conserv. Com. Austin, Tex.

USDA. 1979. Animal waste utilization on cropland and pastureland: a manual for evaluating agronomic and environmental effects. USDA Utiliz. Res. Rep. No. 6. Sci. and Ed. Admin., USDA, Washington, D.C.

VanDyke, L.S., D.J. Bosch, and J.W. Pease. 1999. Impacts of within-farm soil variability on nitrogen pollution control costs. J. Agr. Appl Econ.. 31 (April 1999): 149-159.

Warrick, J. and S. Leavenworth. 1996 (March 9). Who will rescue the ravaged river? The News \& Observer. Raleigh, N.C.

Williams, J.R. 1990. The erosion productivity impact calculator (EPIC) model: a case history. Philosoph. Trans. of the Royal Soc. of London: Series B 329:421-428.

Williams, J.R. 1995. The EPIC model. In: Computer Models of Watershed Hydrology, V.P. Singh, ed, ch. 25, 909-1000. Highlands Ranch, Colo: Water Resour Publ.

Williams, J.R., J.G. Arnold, and R. Srinivasan. 2000. The APEX Model. BRC Report No. 00-06, Blacklands Res. Center, Texas Agr. Exp. Stat., Texas Agr. Exten. Serv., Texas A\&M Univ. System, Temple, Tex.

Williams, J.R., C.A. Jones, P.W. Gassman, and L.M. Hauck. 1995. Simulation of animal waste management with APEX. In: Innovations and New Horizons in Livestock and Poultry Manure Management, 22-26. Austin, Tex., 6-7 September. 


\title{
Runoff and soil loss in undisturbed and roller-seeded shrublands of semiarid Argentina
}

\author{
MANUEL O. AGUILERA, DIEGO F. STEINAKER, AND MANUEL R. DEMARIA
}

Authors are Range Scientist, Biologist, and Wildlife Ecologist, San Luis Experimental Station, Instituto Nacional de Tecnología Agropecuaria (INTA), CC 17, Villa Mercedes, 5730, San Luis, Argentina.

\begin{abstract}
Vegetation influences runoff and soil losses in semiarid environments. In shrublands of Central Argentina, grazing has resulted in a reduction of plant cover, an increase in the proportion of bare soil, and eroded soils. Patterns of runoff and soil losses affected by seeding cultivated grasses were evaluated. We investigated the effects of roller-seeding of Cenchrus ciliaris $L$ and the influence of microsite cover-type on the dynamics of water erosion. Evaluated cover-types were: bare soil, shortgrass cover, and tallgrass cover. Evaluations were performed 2 growing seasons after roller-seeding. The experimental design was a split-plot, replicated 3 times using a portable rainfall simulator. After simulation runs of $45 \mathrm{~min}$ at an average rate of $110 \mathrm{~mm}$ hour ${ }^{-1}$, runoff of tallgrass cover was the least, whereas bare soil and shortgrass cover had similar values (ca. 60\%). However, both types of grass cover reduced soil splash compared to the bare soil cover-type. An exponential function between runoff and soil loss suggested that increasing runoff beyond $60 \%$ produced an abrupt rising of sediment loss. Roller-seeding did not influence runoff or sediment loss at the microsite-scale. Nevertheless, roller-seeding reduced the proportion of area covered by microsites prone to erosion (bare soil and shortgrass cover-types) at the whole plot level. We propose that any management tool that promotes the replacement of bare soil and shortgrasses by tallgrasses should reduce runoff and increase forage productivity via amelioration of hydrologic conditions of the rangeland site. Conversely, overgrazing will result in more bare soil, increasing runoff, and further intensifying the loss of sediments by detachment.
\end{abstract}

Key Words: rainfall simulator, runoff, semiarid shrublands, soil erosion, vegetation cover

\footnotetext{
Research was funded by the National Institute of Agricultural Technology of Argentina (INTA). Authors thank Andrew Mack and Eleni A. Kalitsis, scholars of the Association of Canadian Community Colleges (ACCC), for their help in data collection. Other important contributors to this study were: A. Belgrano Rawson who permitted this study at Estancia Lomas Blancas, S. Sayavedra who carried out the construction of the rainfall simulator, and N. Maceira who promoted the intership program in San Luis. The manuscript was improved by comments from $\mathrm{C}$. Mario Rostagno, David L. Anderson, Carlos B. Passera, and two anonymous reviewers.

Manuscript accepted 25 Aug. 02
}

\begin{abstract}
Resumen
La vegetación afecta los patrones de escorrentía y pérdida de suelo en los ambientes semiáridos. En arbustales del Centro de Argentina, el pastoreo ha producido reducciones en la cobertura vegetal, aumento del suelo desnudo, y erosión. Se evaluaron los patrones de escorrentía y pérdida de suelo afectados por tratamientos de siembra de pastos cultivados mediante el rolado. Nuestro estudio examinó los efectos del rolado y siembra de Cenchus ciliaris $\mathrm{L}$ y la influencia del tipo de micrositio en la dinámica de la erosión hídrica. Los tipos de cobertura evaluados fueron: suelo desnudo, cobertura de pastos cortos, y cobertura de pastos altos. Las evaluaciones se realizaron 2 estaciones de crecimiento después del tratamiento de rolado y siembra. El diseño experimental fue de parcelas divididas, replicado 3 veces utilizando un micro simulador de lluvia móvil. Después de simulaciones de $45 \mathrm{~min}$ a una tasa promedio de $110 \mathrm{~mm} \mathrm{~h}^{-1}$, la escorrentía en pastos altos fue la menor, mientras que en suelo desnudo y en pastos cortos fue similar (aprox. 60\%). Sin embargo, ambos tipos de cobertura de pastos redujeron el desprendimiento de sedimentos comparando con el caso de suelo desnudo. La relación entre escorrentía y pérdida de suelo fue exponencial. La pérdida de sedimentos aumentó abruptamente cuando la escorrentía superaba $60 \%$. El tratamiento de rolado y siembra no afectó la escorrentía ni la pérdida de sedimentos a la escala de micrositio. De todas maneras, el rolado redujo la proporción de micrositios más sensibles a ser afectados por erosión (suelo desnudo y cobertura de pastos cortos). Nosotros proponemos que cualquier herramienta de manejo que promueva el reemplazo de suelo desnudo y de pastos cortos por pastos altos debe reducir la escorrentía e incrementar la productividad forrajera mediante el mejoramiento de las condiciones hidrológicas del sitio. A la inversa, una mayor degradación con mayor proporción de suelo desnudo llevará los valores de escorrentía a más del $60 \%$, desencadenando el proceso de desprendimiento de sedimentos.
\end{abstract}

In semiarid and arid regions vegetation causes spatial heterogeneity at the microsite level, changing the pattern of water flux, therefore affecting runoff and soil losses (Weixelman et al. 1997, Cammeraat and Imeson 1999, Cerdá 1999, Reid et al. 1999, Valentin et al. 1999). Grazing can affect the pattern of vegetation cover, resulting in greater soil erosion (Wood and Blackburn 1981, 1984, Braunack and Walker 1985, Naeth et al. 1990, Chanasyk and Naeth 1995). The effects of grazing include: reduction of plant biomass, compaction of soil, reduction of litter, and undesiderable successional trends. These unfavorable trends 
often result in the replacement of bunchgrasses by sodgrasses affecting water infiltration responses (Knight et al. 1984, McCalla et al. 1984, Eckert et al. 1986, Blackburn et al. 1992).

In Central Argentina (provinces of San Luis, Córdoba and La Rioja), livestock grazing is widespread resulting in undesirable vegetation changes and soil erosion (Báez 1946, Morello 1958, Cabido et al. 1994). Adjusting livestock rates and allowing rest to grazed paddocks have resulted in positive changes of range condition (Anderson et al. 1980). Improvement of range condition is associated with the replacement of colonist shortgrasses for more productive tallgrasses (Anderson et al. 1980). Additionally, the incorporation of Cenchrus ciliaris L (Buffel grass) is primarily a management strategy to provide rapid, initial establishment of a grass cover on denuded areas. Buffel grass is recommended because it is a perennial species that establishes rapidly, produces palatable forage, and is tolerant to drought (Namur 1985, Skousen and Call 1987). However, Buffel grass has a high percent failure for colonization due to lack of runners and poor competitive ability of seedlings (Gardener and McIvor 1986, Hacker 1989). Buffel grass would also be effective in areas where there is a lack of vegetation recovery because of reduced local seed sources and seed banks (Basher and Lynn 1996). The most common equipment used to incorporate Buffel grass is a roller-chopper with the addition of a seeding device.

Some studies have been conducted in Argentina simulating roller disturbance to determine the percent recovery of shrubs and grasses (Passera et al. 1992, 1996). However, the effects of the roller equipment on runoff, soil loss, and Buffel grass establishment have not been studied. Passera et al. (1992) found that after shrub removal, litter cover was $60 \%$ greater and establishment of native grasses was augmented in treated areas. A later study on the effects of shrub control showed that reduction without elimination of woody plants and site disturbance allowed the reappearance of early successional species, native forbs and grasses (Passera et al. 1996). However, in areas with high grass cover, shrub removal did not result in significant increases of forage species (Passera et al. 1996). This suggested that shrub removal would only be advisable in denuded pastures and overgrazed areas.

No studies have been conducted to determine the effects of revegetating Buffel grass using the roller technique on

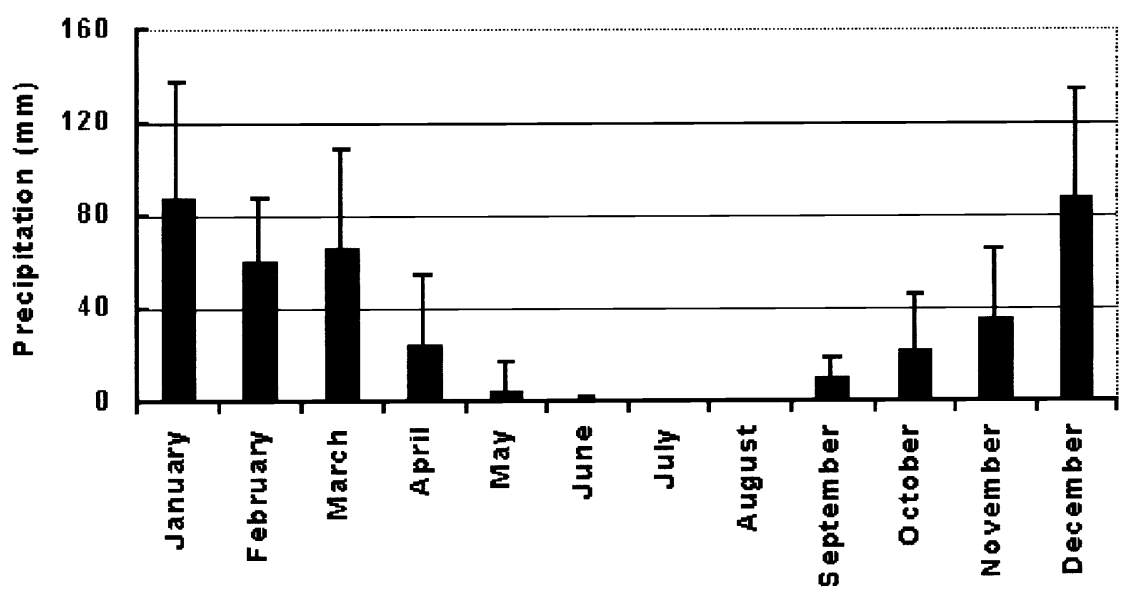

Fig. 1. Monthly average precipitation $(X \pm S D)$ at Ea. Lomas Blancas, San Luis (1990-1999). Annual average precipitation $=399.9 \pm 75$.

the reduction of soil erosion. The objective of this experiment was to provide further knowledge on the hydrological consequences of roller-seeding eroded shrubland sites. In addition, we estimated soil erosion and runoff for different types of microsites. Evaluated microsites were: a) soil denuded of vegetation, b) areas covered with shortgrasses, and c) areas covered with tallgrasses. In Central Argentina, degraded rangelands usually have a high proportion of bare soil and shortgrass microsites. After revegetation, these microsites are colonized by vigorous tallgrasses. Runoff and soil losses were evaluated in roller-seeded plots, and in undisturbed controls using a portable rainfall simulator.

\section{Study site}

The study site is located in northern San Luis Province, Argentina, in the ecotone between the Monte to the west and the arid Chaco to the northeast (Morello 1958). The ecotone is an open woodland with an uneven cover of trees and a mostly continuous herbaceous layer (Mares et al. 1985). Dominant genera of woody plants are: Acacia, Aspidosperma, Geoffroea, Larrea, and Prosopis (Anderson et al. 1970, Cabrera 1971, Peña Zubiate et al.
1998). Perennial grasses dominate the herbaceous layer in areas with mean annual precipitation $>300 \mathrm{~mm}$ (Cabido et al. 1993). Aristida, Chloris, Digitaria, Eragrostis, Neobouteloua, Pappophorum, Setaria, and Trichloris are typical warmseason-grass genera (Anderson et al. 1970, Peña Zubiate et al. 1998).

The study was conducted at Estancia Lomas Blancas (3243'54"S 66 $\left.44^{\circ} 32^{\prime \prime} \mathrm{W}\right)$. The ranch is approximately $80 \mathrm{~km}$ northwest of the city of San Luis. The elevation is $600 \mathrm{~m}$ asl and the region receives on the average $400 \mathrm{~mm}$ of rain per year, with the majority falling in the summer (Fig. 1). Storms are frequently torrential, lasting short periods but with high intensity. These events may be responsible for sharp changes in the dynamics of water erosion which so dramatically affect soil loss. Unfortunately, data on precipitation intensity is lacking for the site. Our study focussed on the dynamics of erosion in response to rainfall events of high intensity.

The soil at the study site is a Typic Haplocalcid (Peña Zubiate, personal communication), with signs of sheet erosion (Table 1). Typic Haplocalcids are common in desert areas of the world (Soil Survey Staff 1999). At Lomas Blancas, the subsoil is often at the surface. The overall slope is $1 \%$. The microtopography is undulating with some evidence of erosion.

Table 1. Soil characteristics before the experiment. Horizon depth, organic matter, total N, texture and $\mathrm{CaCO}_{3}$ of the study area: Typic Haplocalcid, Lomas Blancas series (Peña Zubiate C., personal communication).

\begin{tabular}{ccccccc}
\hline \hline Depth & Organic matter & Total N & Sand & Silt & Clay & $\mathrm{CaCO}_{3}$ \\
\hline$(\mathrm{cm})$ & $(\%)$ & $(\%)$ & $(\%)$ & $(\%)$ & $(\%)$ & $(\%)$ \\
$0-15$ & 1.5 & 0.08 & 66.4 & 30.6 & 3.0 & -- \\
$15-35$ & 1.1 & 0.06 & 69.8 & 27.7 & 2.5 & -- \\
$35-70$ & 0.9 & 0.06 & 55.3 & 35.5 & 9.2 & 10 \\
$>70$ & 0.6 & 0.04 & 50.1 & 45.2 & 4.7 & 15 \\
\hline
\end{tabular}




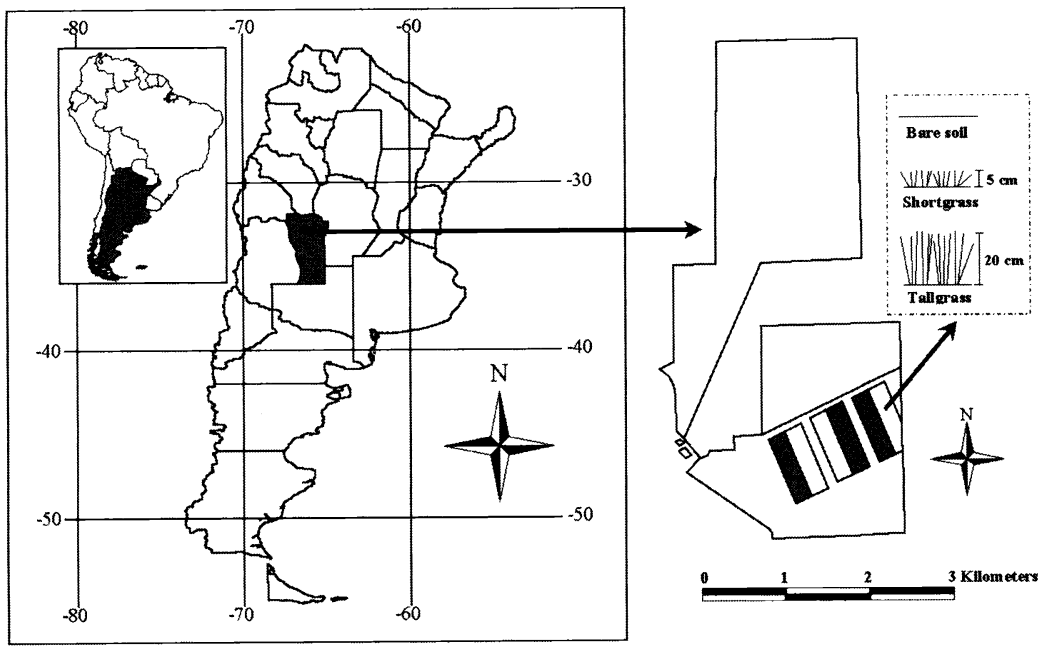

Fig. 2. Location of San Luis Province in Argentina, paddocks at Lomas Blancas Ranch, and experimental plots $($ white areas $=$ controls, shaded areas $=$ roller-seeded). Microsite covertypes were considered sub-plots according to a split-plot design.

Most ranches in the area utilize these woodland sites as grazinglands for livestock (cows and goats). In areas not protected from grazing, vegetation is patchily distributed with areas of bare soil as large as $100 \mathrm{~m}^{2}$ in the intershrub spaces. The most conspicuous tree is Prosopis flexuosa (Lag.) DC, algarrobo. The shrub Larrea divaricata Cav, jarilla, is the dominant species. Sites physognomy is characterized as jarillales, creosote scrub, (Morello 1958, Cabido et al. 1994).

\section{Materials and Methods}

The experimental area was divided into 4 blocks. Blocking was applied across a gradient in the abundance of creosote bush (Fig. 2). One half of each block was randomly selected and treated with a tractor driven roller-chopper on 15 January 1998. Controls and rolled-seeded areas were of 2-4 ha each. The roller weighs approximately $6000 \mathrm{~kg}$. Buffel grass seed was simultaneously incorporated into the soil at a rate of $5 \mathrm{~kg} \mathrm{ha}^{-1}$. Adult Prosopis-trees were left intact. On the other hand, shrubs were cut and chopped into pieces. Seedling emergence was satisfactory; not only for Buffel grass, but also for native grasses, resulting in a mixture of introduced and native species growing in the treated area. However, seedling mortality reduced Buffel grass density, as it is usually observed in these types of seedings (M.O. Aguilera, personnal observation). At the time of erosion evaluation, cover was estimated (Table 2) using the point quadrat method (Daget and Poissonet 1971) modified for the Monte region by Passera et al. (1983).
Runoff and soil losses were estimated in seeding. For this study, only 3 of the 4 blocks were sampled $(n=3)$. Time constraints in data collection and change in environmental conditions caused this reduction in replicates. Within treated and control areas, microsites that accounted for a determined set of characteristics were selected in the following manner. Three types of microsites were evaluated (Fig. 2) for each block and treatment combination $(\mathrm{N}=18 ; 3$ blocks $\times 2$ treatments x 3 microsite-types): (a) bare soil, (b) shortgrass cover (Neobouteloua July 1999, about 18 months after roller-

${ }^{1}$ Nomenclature follows Anderson et al. (1970). loposthachya [Gris.] Gould), and (c) tallgrass cover (Aristida mendocina Phil). Both species were the most abundant grasses in undisturbed and treated areas (Table 2). A point was randomly located $10 \mathrm{~m}$ beyond the boundaries of control and treated areas to avoid edge effects. Microsite types, nearest to the selected point, were chosen for locations to be evaluated using a portable rainfall simulator. Erosion plots were located away from influence of woody-species cover by determining a minimum distance of $2 \mathrm{~m}$ from the plot to the edge of surrounding canopies. In addition, 2 erosion plots under the influence of Prosopis-trees were evaluated. These were not included in the analysis of variance because of a lack of adequate replication, besides the unrealistic situation of responses to simulated rainfall under the tree canopy. However, these estimates provided valid responses for a non-eroded condition and were included in the correlation analyses $(\mathrm{N}=$ $18+2=20$ ).

In determining plot locations, flat areas with no slope were selected. Accounting for slope was a critical factor because of the small dimensions of the erosion plot $\left(625 \mathrm{~cm}^{2}\right)$ so that microsite-type and treatment were the only influencing factors. More than $90 \%$ of the plot corresponded to the cover-type evaluated. Plots were always located in areas with similar topography, at the top of the catena. Circular areas of bare soil microsites with at least a $1 \mathrm{~m}$ radius were selected to avoid the

Table 2. Relative cover (\%) of undisturbed and roller-seeded shrublands, after 18 months of imposing treatments, in Ea. Lomas Blancas, San Luis, Argentina (Steinaker D.F., personnal communication). Note: $0.0 \%$ cover indicates cover values less than $0.1 \%$.

\begin{tabular}{|c|c|c|c|}
\hline Cover-type & Species $^{1}$ & Undisturbed & Roller-seeded \\
\hline & & $(\%)$ & $(\%)$ \\
\hline Bare-soil & & 35.4 & 17.8 \\
\hline Litter & & 2.0 & 18.3 \\
\hline \multirow[t]{3}{*}{ Shrubs-Trees } & Larrea divaricata $\mathrm{Cav}$ & & \\
\hline & Prosopis flexuosa (Lag.) DC & 10.6 & 5.4 \\
\hline & & 0.0 & 0.0 \\
\hline \multirow[t]{4}{*}{ Shortgrasses } & Neobouteloua lophostachya (Gris.) Gould & 19.2 & 6.2 \\
\hline & Sporobolus pyramidatus (Lam.) Hitchcook & 3.0 & 0.0 \\
\hline & Eragrostis orthoclada Hackel & 2.5 & 1.7 \\
\hline & Aristida adscencionis $\mathrm{L}$ & 2.0 & 2.1 \\
\hline \multirow[t]{7}{*}{ Tallgrasses } & Aristida mendocina Phil & 17.2 & 28.2 \\
\hline & Pappophorum caespitosum R.E.Fr. & 3.0 & 2.1 \\
\hline & Pappophorum philliphianum Parodi & 1.0 & 0.0 \\
\hline & Gounia paraguariensis (O.K.) Par & 1.0 & 1.7 \\
\hline & Digitaria californica (Benth.) Henrard & 0.5 & 1.2 \\
\hline & Setaria leucopila (Lam-Scrib.) K. Schuman & 0.0 & 0.4 \\
\hline & Cenchrus ciliaris $\mathrm{L}$ & 0.0 & 3.7 \\
\hline \multirow[t]{2}{*}{ Forbs } & Conyza sp. & 2.0 & 10.0 \\
\hline & Other herbs & 0.5 & 1.2 \\
\hline
\end{tabular}


interference of the surrounding vegetation. Four bulk density samples (0-5 cm depth) were taken, one in each corner, outside the erosion plot. Bulk density was analyzed using the core method (Black 1965). Statistical analyses were performed for plot means $(n=3)$, and no differences were found between microsites or treatments. The overall mean of bulk density suggested that superficial soil was compacted in all microsites $\left(1.59 \mathrm{~g} \mathrm{~cm}^{-3}\right)$. Samples collected under the influence of Prosopis-trees with higher organic matter, showed significantly lower bulk density values $\left(1.36 \mathrm{~g} \mathrm{~cm}^{-3}\right)$. Most of the cover of each treatment was represented by the tested microsites (Table 2).

Rainfall was applied with a portable drop-forming rainfall simulator. This is a $150-\mathrm{cm}$ high mobile simulator built of acrylic with a square base (internal side = $25 \mathrm{~cm}$ ) driven into the soil (Irurtia and Mon 1994). The rainfall chamber has 49 tubing tips of $0.5 \mathrm{~mm}$ inside diameter. According to Irurtia and Mon (1994) generated raindrops are $5.1 \mathrm{~mm}$ in diameter and achieve a final velocity of $5.09 \mathrm{~m} \mathrm{sec}^{-1}$, delivering a kinetic energy of $15 \mathrm{~J} \mathrm{~m}^{-2} \mathrm{~mm}^{-1}$. Sufficient rainfall was applied to ensure runoff from all microsites at a nominal rate of $110 \mathrm{~mm}_{\text {hour }}{ }^{-1}$.

Runoff was collected at 5-min intervals during 45-min simulated rainfall events. Runoff (\%) was defined as the ratio between the runoff and the simulated rainfall volumes for a given period. The soil was dry previous to the simulations. Depth of the wetting front was measured by excavating in the soil after each simulated rainfall. Estimates per plot were the average of three measurements that were recorded over the plot area using a measurement tape. Soil loss was estimated from the total runoff collected by filtering through a \# 1 Whatman filter, drying at $105^{\circ} \mathrm{C}$ for 24 hours, weighting and converting the obtained sediment to soil detachment in $\mathrm{g} \mathrm{m}^{-2}$.

A split-plot design (Fig. 2) was used to determine the significance of blocks (3), whole plots $=$ treatment (undisturbed or roller-seeded areas), subplots = micrositetype (bare soil, shortgrass cover, or tallgrass cover), and the interaction term (treatment $x$ microsite). Runoff $(\%)$ was arc-sine transformed to satisfy assumptions of normality and homoscedasticity. Arc-sine transformation is often recommended for rates (Snedecor and Cochran 1980). For similar purposes, logarithmic transformation was applied to soil loss ( $\mathrm{g}$ $\mathrm{m}^{-2}$ ). Repeated-measure analysis of the transformed variables was considered at 5 ,
$10,15,20,25,30,35,40$, and $45 \mathrm{~min}$ of the elapsed time of the simulated rainfall event. Actual application rate was $109.7 \pm$ $8.29 \mathrm{~mm}$ hour $^{-1}$ (mean $\pm \mathrm{SD}, \mathrm{CV}=7.5 \%$ ), so runoff rates were adjusted by the water application rate for each recorded time (Frasier et al. 1998). Final accumulated runoff $(\%)$ and soil loss $\left(\mathrm{g} \mathrm{m}^{-2}\right)$ were analyzed separately as steady-state erosion parameters. Steady-state condition was defined at $45 \mathrm{~min}$ because no significant time-based differences were observed after $40 \mathrm{~min}$. Analyses of variance were based on restricted likelihood estimation and Satterthwaite's procedure for approximating F-tests, particularly suited for split-plot analysis (Schabenberger, O. 1996. "Some tricks about analyzing split-plot designs", http://www.stat.vt.edu/ oliver/SplitPlot.html).
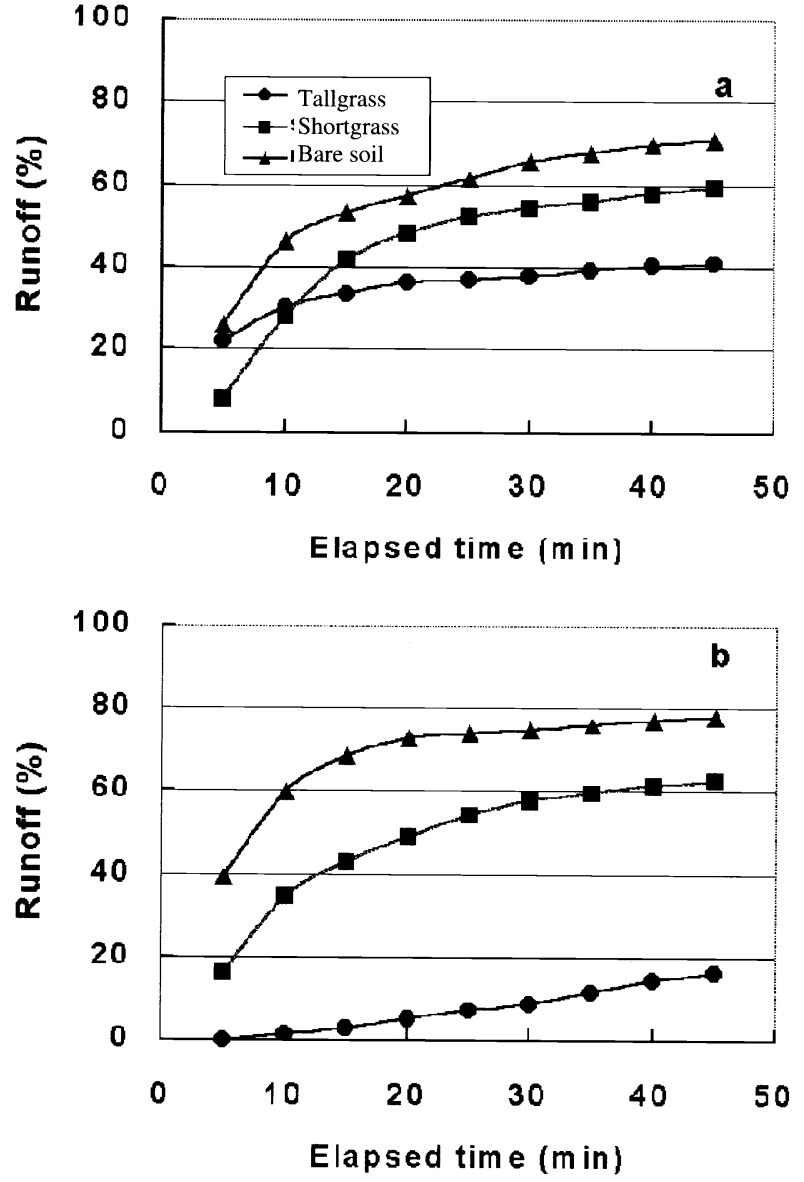

Fig. 3. Runoff (\%) under undisturbed (a) and roller-seeded (b) sites in semiarid shrublands of Argentina. Runoff simulation runs lasted $45 \mathrm{~min}$ at a nominal average rain intensity of $110 \mathrm{~mm}$ hour $^{-1}$. The only significant time- $x$ factor- interactions was time $x$ microsite because differences increased over time $(P<0.0001)$. 

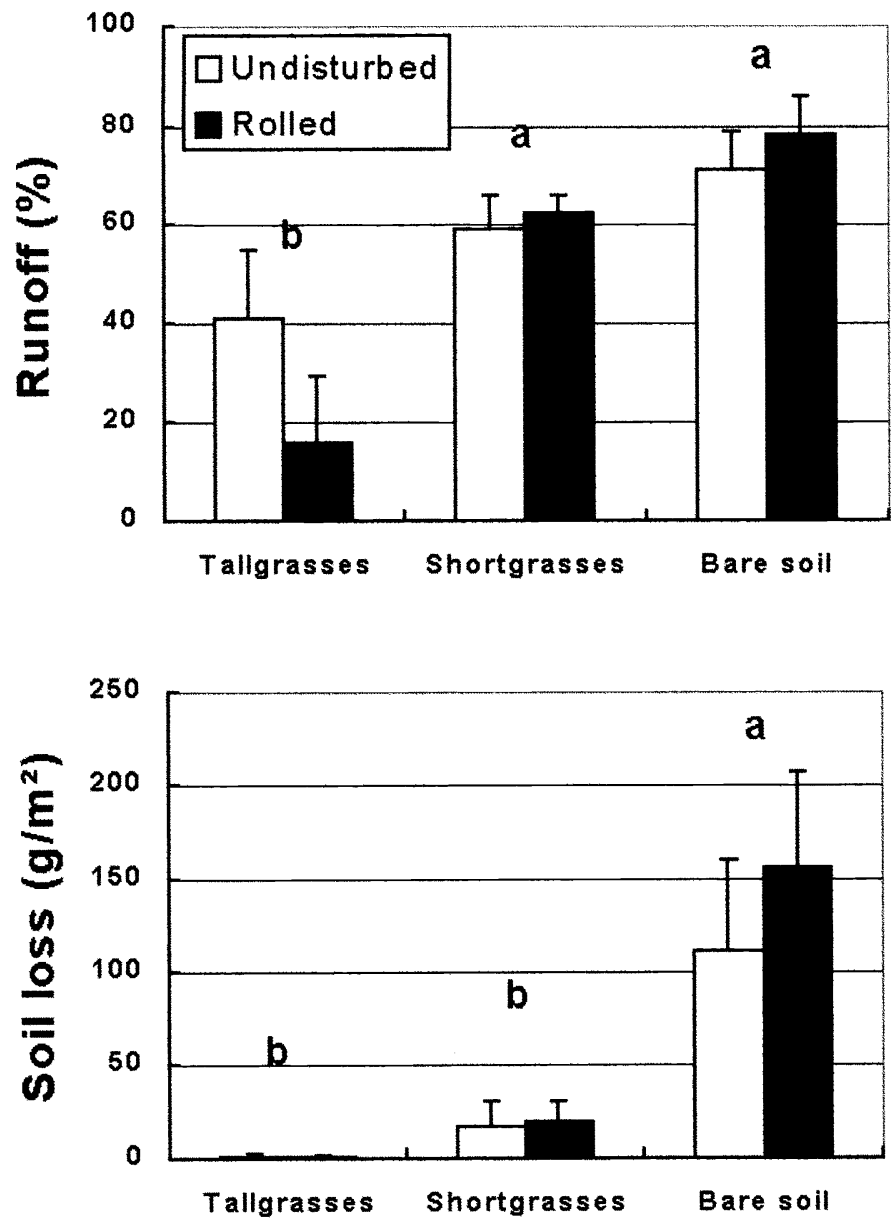

Fig. 4. Effect of treatment (undisturbed or roller-seeded) and microsite (tallgrass, shortgrass and bare soil cover-types) on runoff and soil loss after simulation runs of $45 \mathrm{~min}$ at an average rain intensity of $110 \mathrm{~mm}$ hour $^{-1}$. Different letters indicate significant differences between cover-types at $5 \%$ level. Treatment and treatmeant $x$ microsite interaction was not significant. Vertical lines on top of bars are SD.
Digitaria californica [Benth.] Henrard, Diplachne dubia [H.B.K.] Scribn., and Setaria leucopila [Lam-Scrib.] K.Schuman). If tallgrasses are already abundant in the site, little is attained by roller-seeding in terms of forage production (Passera et al. 1996).

Roller-seeding changed the proportion of microsite-cover types (Table 2) reducing bare soil and shortgrasses of scant biomass, and increasing tallgrasses. Rolling did not affect infiltration patterns at the microsite-scale, but may reduce runoff at larger scales. Runoff (\%) was closely related to depth of the wetting front $(\mathrm{cm})$, providing a good field estimate of runoff for large rainfall events (Fig. 5).

\section{Soil loss}

The scale of our study provides information on soil detached through raindrop impacts, the first stage in the process of soil erosion. Slope gradient and length were not considered. Although observed values were only a fraction of probable total soil loss, significant effects on sediment loss by vegetation cover were observed at the microsite-scale. The highest sediment loss by splash was in bare soil microsites (Fig. 4). Areas covered by Neobouteloua lophostachya, colonizer shortgrass of overgrazed sites, provided sufficient soil protection to reduce sediment detachment (Fig. 4). Singer et al. (1981) found that biomass cover reduced more transported than splash sediment, so vegetation effects are probably augmented at larger spatial scales. In shortgrass dominated sites, if plant cover were further degraded resulting in increased bare soil
The repeated-measure analysis of variance yielded a non-significant time $x$ treatment interaction, but microsite differences increased over time (significant time- $\mathrm{x}$ microsite- interaction, $\mathrm{P}<0.0001)$.

At the end of the 45-min period of simulated rainfall, runoff from tallgrass microsites was significantly lower than shortgrass and bare soil microsites (Fig. 4). Shortgrass and bare soil microsites had similar runoff, about $60 \%$. These estimates corresponded to $64-66 \mathrm{~mm}$ hour $^{-1}$ of observed runoff. Consequently, improvement of infiltration is expected, when management tools are used to promote the replacement of short low-productive pioneer grasses (e.g. Neobouteloua lophostachya [Gris.] Gould, Aristida adscencionis L, Sporobolus pyramidatus [Lam.] Hitchoock, and Michrochloa indica [L.F.] Beauv), by highly-productive tallgrasses (e.g. Aristida mendocina L, Trichloris crinita [Lag.] L.R. Parodi, Pappophorum caespitosum R.E.Fr.,

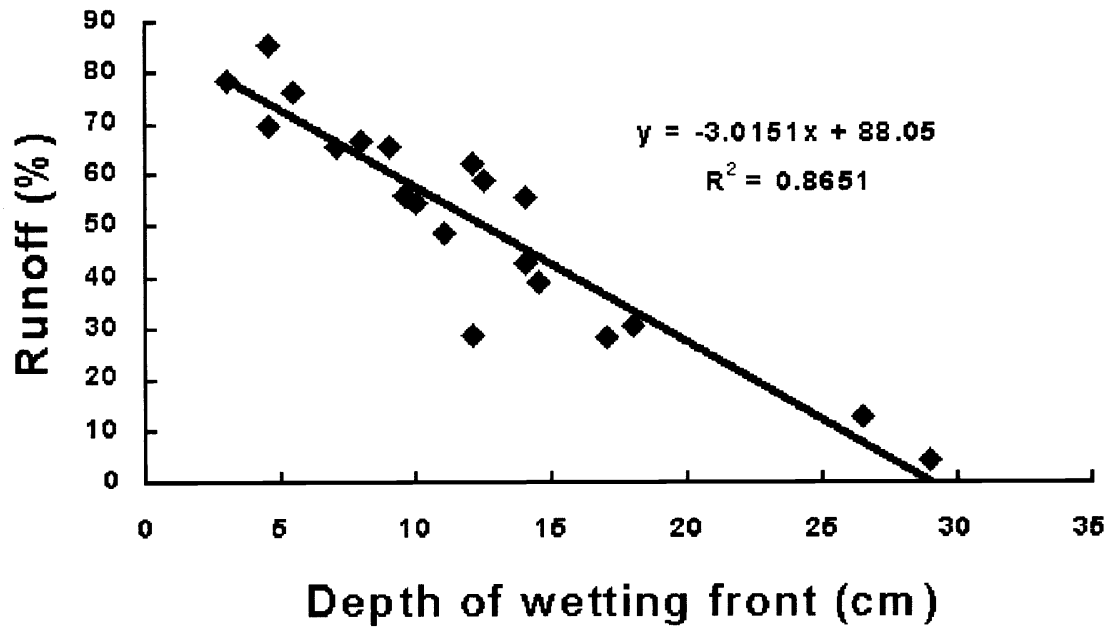

Fig. 5. Runoff related to depth of wetting front after simulation runs of $45 \mathrm{~min}$ at an average intensity of $110 \mathrm{~mm} \mathrm{hour}^{-1}(\mathrm{~N}=\mathbf{2 0})$. 


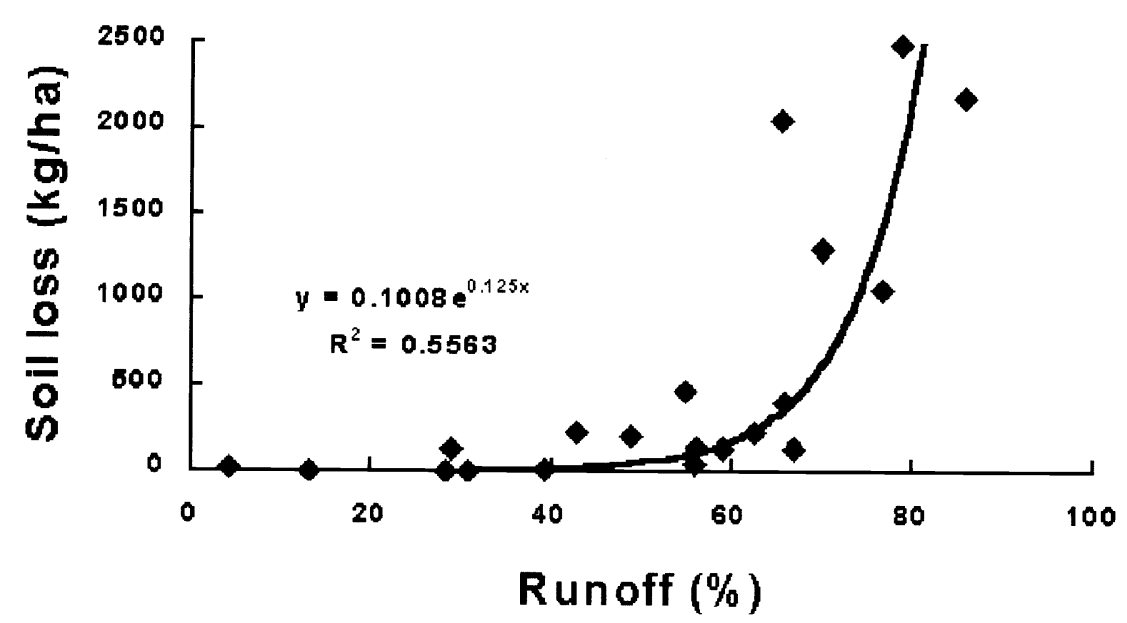

Fig. 6. Exponential relationship of sediment splash $\left(\mathrm{kg} \mathrm{ha}^{-1}\right)$ with runoff for simulation runs of $45 \mathrm{~min}$ at an average intensity of $110 \mathrm{~mm} \mathrm{hour}^{-1}(\mathrm{~N}=20)$.

cover, erosion would greatly accelerate. The relationship between runoff (\%) and sediment loss by splash $\left(\mathrm{kg} \mathrm{ha}^{-1}\right)$ demonstrated that beyond $60 \%$ (values of runoff for shortgrass cover-types), soil losses increased sharply (Fig. 6).

Tallgrass cover-types registered negligible soil loss, even after $45 \mathrm{~min}$ of rainfall at about $110 \mathrm{~mm} \mathrm{hour}^{-1}$. The present evaluation is relevant because most soil loss is often determined by high-intensity rainfall events under natural conditions (Castillo et al. 1997, Coronato and del Valle 1993, Rostagno et al. 1999). Consequences of high rainfall intensity events on aggregate breakdown and sediment transport have recently been determined for denuded and vegetated plots in a semiarid environment (Martínez-Mena et al. 1999). Although our comparative study did not evaluate sediment transported in rills or large concentrated flows, it shows the importance of vegetation cover to reduce the impact of rain splash. Besides, it is the first estimate of sediment losses for the semiarid Chaco.

Well-managed rangelands (adequate livestock rates and satisfactory rest periods) commonly posses stands with a high proportion of tallgrasses (Anderson et al. 1980). Increasing tallgrass cover may result in further increases of forage productivity via amelioration of hydrologic conditions of the rangeland site. We hypothesize that control of erosion should result in improvements of infiltration rates, thereby triggering a positive feedback mechanism resulting in higher primary productivity of the herbaceous vegetation layer.

\section{Management implications}

Caution should be taken to extrapolate results from microsites to the dynamics of landscape hydrology (Bergkamp 1998, Cammeraat and Imeson 1999). However, vegetation patch types are responsible for substantial transfer of water and sediments at small scales, of ecological significance in semiarid conditions (Reid et al. 1999). Cover-type of microsites appeared to determine runoff and soil losses in situ, more than overall disturbances per se in the shrublands studied in central Argentina. The evaluated roller-seeding treatment evaluated herein, reduced the proportion of microsites more exposed to erosion (bare soil and shortgrass covertypes). Reduction of runoff and soil loss are expected after using management techniques that result in vegetation dynamics promoting accumulation of litter, reduction of bare soil, and successional changes associated with the replacement of colonist shortgrasses by productive tallgrasses. This successional process must provide better condition ranges, resulting from more water infiltrated in the soil and increased forage production.

\section{Literature Cited}

Anderson, D.L., J. del Aguila, and A. Bernardón. 1970. Las formaciones vegetales en la provincia de San Luis. (In Spanish). Revista de Investigaciones Agropecuarias. INTA, Buenos Aires. Series 2:154-183.

Anderson, D.L., J.A. del Aguila, A. Marchi, J.C. Vera, E.L. Orionte, and A.E. Bernardón. 1980. Manejo Racional de un Campo en la Región Arida de Los Llanos de
La Rioja. (In Spanish). Instituto Nacional de Tecnología Agropecuaria, Buenos Aires, 90 pp.

Báez, J.R. 1946. Dos aspectos de la vegetación del norte de San Luis. II. Con mención sobre forrajeras y malezas. (In Spanish). Revista Argentina de Agronomía 13:69-95.

Basher, L.R. and I.H. Lynn. 1996. Soil changes associated with cessation of sheep grazing in the Canterbury High Country, New Zealand. New Zealand J. Ecol. 20:179-189.

Bergkamp, G. 1998. A hierarchical view of the interactions of runoff and infiltration with vegetation and microtopography in semiarid shrublands. Catena 33:201-220.

Black, C.A. 1965. Methods of Soil Analysis. Amer. Soc. of Agron. Series No. 9, Madison, Wis.

Blackburn, W.H., F.B. Pierson, C.L. Hanson, T.L. Thurow, and A.L. Hanson. 1992. The spatial and temporal influence of vegetation on surface soil factors in semiarid rangelands. Trans. ASAE 35:479-486.

Braunack, M.V. and J. Walker. 1985. Recovery of some surface soil properties of ecological interest after sheep grazing in a semi-arid woodland. Aust. J. Ecol. 10:451-460.

Cabido, M., C. González, A. Acosta, and S. Díaz. 1993. Vegetation changes along a precipitation gradient in Central Argentina. Vegetatio 109:5-14.

Cabido, M., A. Manzur, L. Carranza, and C. González Albarracín. 1994. La vegetación y el medio físico del Chaco Arido en la provincia de Córdoba, Argentina Central. (In Spanish). Phytocoenologia 24:423-460.

Cabrera, A.L. 1971. Fitogeografía de la República Argentina. (In Spanish). Boletín de la Sociedad Argentina de Botánica 14:1-42.

Cammeraat, L.H. and A.C. Imeson. 1999. The evolution and significance of soil-vegetation patterns following land abandonment and fire in Spain. Catena 37:107-127.

Castillo, V.M., M. Martínez-Mena, and J. Albadalejo. 1997. Runoff and soil loss response to vegetation removal in a semiarid envieronment. Soil Sci. Soc. Amer. J. 61:1116-1121.

Cerdá, A. 1999. Parent material and vegetation affect soil erosion in eastern Spain. Soil Sci. Soc. Amer. J. 63: 362-368.

Chanasyk, D.S. and M.A. Naeth. 1995. Grazing impacts on bulk density and soil strength in the foothills fescue grasslands of Alberta, Canada. Can. J. Soil Sci. 75:551-557.

Coronato, F.R. and H.F. del Valle. 1993. Methodological comparison in the estimate of fluvial erosion in an arid closed basin of northeastern Patagonia. J. Arid Environ. 24:231-239.

Daget, P. and J. Poissonet. 1971. Une méthode d'analyse phytologique des prairies (In French). Annales Agronomiques 22:5-41.

Eckert, R.E., F.F. Peterson, and J.T. Belton. 1986. Relation between ecological-range condition and proportion of soil-surface types. J. Range Manage. 39:409-414. 
Frasier, G.W., M. Weltz, and L. Weltz. 1998. Rainfall simulator runoff hydrograph analysis. J. Range Manage. 51:531-535.

Gardener, C.J. and J.G. McIvor. 1986. Characteristics associated with the colonizing ability of introduced pasture species in the semi-arid tropics, p. 456-457. In: P.J. Joss, P.W. Lynch, and O.B. Williams (eds.) Rangelands: a resource under siege. Aust. Acad. Sci., Canberra, Aust.

Hacker, J.B. 1989. The potential for buffel grass renewal from seed in 16-year-old buffel grass-siratro pastures in south-east Queensland. J. Appl. Ecol. 26:213-222.

Irurtia, C.B. and R. Mon. 1994. Microsimulador de lluvia para determinar infiltración a campo (In Spanish). INTA. Instituto de Suelos. Publicación No. 176. Castelar, Buenos Aires.

Knight, R.W., W.H. Blackburn, and L.B. Merril. 1984. Characteristics of Oak Mottes, Edwards Plateau, Texas. J. Range Manage.37:534-537.

Mares, M.A., J. Morello, and G. Goldstein. 1985. The Monte desert and other subtropical semi-arid biomes of Argentina, with comments on their relation to North American arid areas, p. 203-237. In: M. Evenari, I. Noy-Meir, and D.W. Goodall (eds.) Ecosystems of the World, 12A: Hot Deserts and Arid Shrublands, A. Elsevier, Oxford.

Martínez-Mena, M., J. Alvarez Rogel, J. Albadalejo, and V.M. Castillo. 1999. Influence of vegetal cover on sediment particle size distribution in natural rainfall conditions in a semiarid environment. Catena 38:175-190.

McCalla II, G.R., W.H. Blackburn, and L.B. Merril. 1984. Effects of livestock grazing on sediment production, Edwards Plateau of Texas. J. Range Manage. 37:291-294.
Morello, J. 1958. La provincia Fitogeográfica del Monte (In Spanish). Op. Lilloana 2:1-155

Naeth, M.A., R.L. Rothwell, D.S. Chanasyk, and A.W. Bailey. 1990. Grazing impacts on infiltration in mixed prairie and fescue grassland ecosystems of Alberta. Can. J. Soil Sci. 70:593-605.

Namur, P. 1985. Buffel Grass: generalidades, implantación y manejo. (In Spanish) Instituto Nacional de Tecnología Agropecuaria. EEA La Rioja, Chamical, La Rioja.

Passera, C.B., O. Borsetto, and L.I. Allegretti. 1996. Short-term effects of shrub control on two different plant communities in Argentina. J. Arid Environ. 34:415-420.

Passera, C.B., O. Borsetto, R.J. Candia, and C.R. Stasi. 1983. Método del "Point Quadrat Modificado" (In Spanish), p. 135-152. In: R. Candia and R. Braun (eds.) Taller sobre arbustos forrajeros en zonas áridas y semiáridas. Argentina.

Passera, C.B., O. Borsetto, R.J. Candia, and C.R. Stasi. 1992. Shrub control and seeding influences on grazing capacity in Argentina. J. Range Manage. 45:480-482.

Peña Zubiate, C.A., D.L. Anderson, M.A. Demmi, J.L. Saenz, and A. d'Hiriart. 1998. Carta de Suelos y Vegetación de la Provincia de San Luis (In Spanish). Instituto Nacional de Tecnología Agropecuaria, EEA San Luis, Villa Mercedes.

Reid, K.D., B.P. Wilcox, D.D. Breshears, and L. MacDonald. 1999. Runoff and erosion in a Piñon-Juniper woodland: influence of vegetation patches. Soil Sci. Soc. Amer. J. 63:1869-1879.

Rostagno, C., F. Coronato, H. del Valle, and D. Puebla. 1999. Runoff and erosion in five land units of a closed basin of norhteastern Patagonia. Arid Soil Res. Rehab. 13:281-292.
Singer, M.J., Y. Matsuda, and J. Blackard. 1981. Effect of mulch rate on soil loss by raindrop splash. Soil Sci. Soc. Amer. J. 45: 107-110.

Skousen, J.G. and C.A Call. 1987. Grass and forb species for revegetation of mixed soillignite overburden in East Central Texas. J. Soil Water Conserv. 42:438-442.

Snedecor, G.W. and W.G. Cochram. 1980. Statistical Methods. The Iowa State University Press, Ames, Iowa.

Soil Survey Staff. 1999. Soil Taxonomy. A basic system of soil classification for making and interpreting soil surveys. USDA-NRCS, Agr. Handb. No 436, $2^{\text {nd }}$ ed. U.S. Gov. Print. Office, Washington DC.

Thurow, T.L., W.H. Blackburn, and C.A. Taylor, Jr. 1986. Hydrologic characteristics of vegetation types as affected by livestock grazing systems, Edwards Plateau, Texas. J. Range Manage. 39:505-509.

Valentin, C., J.M. d'Herbès, and J. Poesen. 1999. Soil and water components of banded vegetation patterns. Catena 37:1-24.

Weixelman, D.A., D.C. Zamudio, K.A. Zamudio, and R.J. Tausch. 1997 Classifying ecological types and evaluating site degradation. J. Range Manage. 50:315-321.

Wood, M.K. and W.H. Blackburn. 1981 Grazing systems: their influence on infiltration rates in the Rolling Plains of Texas. J. Range Manage. 34:331-335.

Wood, M.K. and W.H. Blackburn. 1984. Vegetation and soil responses to cattle grazing systems in the Texas Rolling Plains. $\mathrm{J}$. Range Manage. 37:303-308. 


\title{
Evaluation of USLE and RUSLE estimated soil loss on rangeland
}

\author{
KENNETH E. SPAETH JR., FREDERICK B. PIERSON JR., MARK A. WELTZ, AND WILBERT H. BLACKBURN
}

Authors are USDA-NRCS Rangeland Hydrologist and USDA-ARS Research Hydrologist, both at NW Watershed Research Center, Boise, Ida; USDA-ARS National Program Staff, Beltsville, Md.; and USDA-ARS Area Director, Ft. Collins Colo.

\begin{abstract}
The Universal Soil Loss Equation (USLE) and the Revised Universal Soil Loss Equation (RUSLE 1.06) were evaluated with rainfall simulation data from a diverse set of rangeland vegetation types (8 states, 22 sites, 132 plots). Dry, wet, and very-wet rainfall simulation treatments were applied to the study plots within a 2-day period. The rainfall simulation rate was $65 \mathrm{~mm} / \mathrm{hr}$ for the dry and wet simulation treatments and alternated between $65-130 \mathrm{~mm} / \mathrm{hr}$ for the very-wet treatment. Average soil loss for all plots for the representative simulation runs were: $0.011 \mathrm{~kg} / \mathrm{m}^{2}, 0.007 \mathrm{~kg} / \mathrm{m}^{2}$, and $0.035 \mathrm{~kg} / \mathrm{m}^{2}$ for the $\mathrm{dry}$, wet, and very-wet simulation treatments, respectively. The Nash-Sutcliffe Model efficiencies $\left(R^{2}\right.$ eff) of the USLE for the dry, wet, very-wet simulation treatments and sum of all soil loss measured in the three composite simulation treatments (pooled data) were negative. This indicates that the observed mean measured soil loss from the field rainfall simulations is better than predicted USLE soil loss. The USLE tended to consistently overpredict soil loss for all 3 rainfall simulation treatments. As the USLE predicted values increased in magnitude, the error variance between predicted and observed soil loss increased. Nash-Sutcliffe model efficiency for the RUSLE was also negative, except for the dry run simulation treatment $\left[R^{2} e f f=0.16\right.$ using $R U S L E$ cover management $(C)$ subfactor parameters from the RUSLE manual $\left(C_{\text {table }}\right)$, NRCS soil erodibility factor $(K)$; and $R^{2} e f f=0.17$ with $C_{\text {table }}$ and $K$ estimated from the soil-erodibility nomograph]. In comparison to the USLE, there was less error between observed and RUSLE predicted soil loss. The RUSLE error variances showed a consistent trend of underpredicted soil loss among the 3 rainfall simulation treatments. When actual field measured root biomass, plant production and soil random roughness values were used in calculating the RUSLE C subfactors: the $R^{2}$ eff values for the dry, wet, very-wet rainfall simulation treatments and the pooled data were all negative.
\end{abstract}

Key Words: erosion models, sheet and rill erosion, rainfall simulation experiments, rangeland health

Since the mid 1940's, the United States Department of Agriculture (USDA) has been using erosion prediction equations as a guide in conservation planning to select suitable structural and field management practices on cropland. The USDA-Natural Resources Conservation Service (NRCS) first applied the

Manuscript accepted 13 Jul. 02.

\section{Resumen}

La Ecuación Universal de Perdida de Suelo (EUPS) y la Ecuación Universal de Perdida de Suelo Revisada (EUPSR 1.06) fueron evaluadas con datos de simulación de lluvia de un grupo diverso de tipos de vegetación de pastizal (8 estados, 22 sitios y 132 parcelas). Los tratamientos de simulación de lluvia, seco, húmedo y muy húmedo se aplicaron en las parcelas de estudio dentro de un periodo de 2 años. Las tasa de simulación de lluvia fue de $65 \mathrm{~mm} / \mathrm{hr}$ para los tratamientos de simulación seco y húmedo y alternada entre $65-130 \mathrm{~mm} / \mathrm{hr}$ para el tratamiento muy húmedo. Los promedios de perdida de suelo para todas las parcelas en las corridas de simulación representativas fueron: $0.011 \mathrm{~kg} / \mathrm{m}^{2}, 0.007 \mathrm{~kg} / \mathrm{m}^{2}$ y $0.035 \mathrm{~kg} / \mathrm{m}^{2}$ para los tratamientos seco húmedo y muy húmedo respectivamente. Las eficiencias del modelo Nash-Sutcliffe ( $\mathbf{R}^{2}$ eff) de la EUPS para los tratamientos seco, húmedo y muy húmedo y la suma de todo el suelo perdido medido en los tres tratamientos compuestos de simulación (datos mezclados) fueron negativas. Esto indica que la media de perdida de suelo observada en las simulaciones de lluvia en el campo es mejor que la predicha por la EUPS. La EUPS tendió a sobepredecir constantemente la perdida de suelo para los 3 tratamientos de simulación de lluvia. Conforme los valores predichos por la EUPS se incrementaron en magnitud, la varianza del error entre la perdida de suelo predicha y observada se incrementó. La eficiencia del modelo Nash-Sutcliffe también fue negativa, excepto para el tratamiento de simulación seco $\left[\mathbf{R}^{2} e f f=\right.$ 0.16, usando los parámetros del subfactor el manejo de cobertura (C) del manual de la EUPSR $\left(C_{\text {tabla }}\right)$, la erodabilidad del suelo, factor (K) de la EUPS y $R^{2}$ eff $=0.17$ con $C_{\text {tabla }}$ y $K$ estimados del nomográfo de la erodabilidad de suelo]. En comparación con la EUPS, hubo menos error entre la perdida de suelo observada y la predicha por la EUPSR. Las varianzas del error de la EUPSR mostraron un tendencia consistente de perdida de suelo no predicha entre los 3 tratamientos de simulación de lluvia. Conforme la cantidad e intensidad de la lluvia se incrementan y el suelo viene a estar mas saturado aumentó la propensión la subestimación. Cuando la biomasa radical actual, la producción de planta y la rugosidad aleatoria del suelo se usaron en calcular los subfactores $C$ del EUPSR: los valores de $\mathbf{R}^{2}$ eff fueron negativos para los tratamientos seco, húmedo y muy húmedo y los datos promediados.

Universal Soil Loss Equation (USLE) on cropland in the early 1960' s to predict sheet and rill erosion. The USLE soil loss estimation and erosion research progressed with 2 Agricultural Handbook publications for predicting rainfall erosion losses 
(Wischmeier and Smith 1965, 1978). Wischmeier (1976) stated: "the USLE was designed to predict soil loss from sheet and rill erosion" and soil loss predicted by the USLE is "that soil moved off the particular slope segment represented by the selected topographic factor." The USLE provided conservation planners with the ability to predict longtime average rates of soil erosion for different cropping systems and management practices in association with a specified soil type, rainfall pattern, and topography. When these predicted losses were compared with NRCS soil loss tolerances $(\mathrm{T})$, they provided specific guidelines for implementing erosion control within specified limits (Wischmeier and Smith 1978).

Wischmeier (1976) stated that the USLE "permits methodical decision-making in soil conservation planning on a site basis." Renard et al. (1997) state that for more than 4 decades, the technology has been valuable as a conservation-planning guide. Government agencies have used the technology for this purpose-to evaluate the benefits of various conservation practices; however, other uses have emerged over the years such as ascertaining compliance with a soil loss standard and a means to prioritize programs based on soil loss. These other uses, whether appropriate or inappropriate have been a point of debate for almost as long as the technology has existed (Wischmeier 1976, Blackburn 1980, Wight and Siddoway 1982).

During the early 1970's, the NRCS and the USDA-Forest Service met to discuss the extension of USLE to undisturbed land, which included rangeland. Since no field data was available on rangelands (as was for cropland: 10,000 plot-years over 40 years), Wischmeier developed a subfactor method for determining permanent pasture, rangeland, and woodland covermanagement factors $(C)$ by extrapolating crop residue to vegetation cover on range and woodland (Wischmeier 1975). In the early 1980's, the NRCS was concerned with the adequacy of the USLE because of anticipated Congressional legislation, which would affect USDA policies. The 1985 Farm Bill required that conservation plans on highly erodible cropland were necessary in order to participate in certain USDA farm programs and cost/share programs. It was becoming increasingly clear that the NRCS needed and desired improved erosion prediction technology. A plan was developed in USDA to update the USLE and begin developing improved erosion prediction technology based on process-based concepts (the Water
Erosion Prediction Project, WEPP; Foster and Lane 1987, Flanagan and Livingston 1995). The USLE was evolving using subfactor methods and the USDA recognized the value of incorporating this technology into a computer program format and extending the technology beyond the original objectives of the early 1980's. The result of this effort was the Revised Universal Soil Loss Equation (RUSLE) (Renard et al. 1997).

Several studies have evaluated the USLE on rangelands. Simanton et al. (1980) compared observed and USLE predicted soil loss on 3 brush-covered and 1 grassland-covered watershed in southeastern Arizona. On brushland watersheds, they concluded that the USLE tended to over predict soil loss during small runoff events and under predicted soil loss with large runoff events. On a grass-covered watershed, soil loss was over predicted. Hart (1984) conducted rainfall simulation studies on sagebrush/grass plant communities in northern Utah. On vegetated plots, the USLE overestimated soil loss on $10 \%$ and $32 \%$ slope plots. The USLE estimates were less accurate on the steeper slope. In rangeland rainfall simulation experiments on 28 sagebrush and shadscale sites in southwest Idaho and northcentral Nevada, Johnson et al. (1984) compared soil loss from field plots with the USLE predicted values for tilled, clipped, grazed, and ungrazed plots. They found good relationships $\left(r^{2}=0.89\right)$ between observed and predicted soil loss on tilled (vegetation removed and soil rototilled) rangeland sites. On all vegetated plots combined (clipped, grazed, and ungrazed plots), coefficients of determination were low $\left(r^{2}=0.27\right)$ between observed and predicted soil loss. Simulated soil loss from ungrazed sites (10 years deferment) showed consistently lower values than the USLE predicted values. Johnson et al. (1984) summarized that "variability in predicted soil losses from sagebrush rangelands indicates a need for more accurate quantification of cover and management conditions."

Renard and Foster (1985) stated: "fundamentally, the USLE is scientifically sound, although clearly, its factor values can be improved for western rangelands." Hawkins (1985) stated: the USLE "does not lead directly to erosion, but produces the intermediate product of storm runoff ... the complications of time and spatial variations in site properties are usually not considered, even when of known consequence." Weltz et al. (1998) reviewed several limitations regarding the USLE:
"USLE is a lumped empirical model that does not separate factors that influence soil erosion, such as plant growth, decomposition, infiltration, runoff, soil detachment, or soil transport. The USLE was designed to estimate sheet and rill erosion from hillslope areas. It was not designed to address soil deposition and channel or gully erosion within watersheds." Renard et al. (1991) summarized, "the fundamental erosion processes and their interactions are not represented, explicitly" in the USLE.

Advancements in hydrology and erosion research have been incorporated into the RUSLE 1.06 (hereon, RUSLE is version 1.06) (Renard et al. 1997). Specific advancements since the USLE include techniques to address slopes over $20 \%$, compound slopes, and time variance adjustments for soil erodibility (Weltz et al. 1998). The RUSLE is an index method containing factors that represent how climate, soil, topography, and land use affect rill and interrill soil erosion caused by raindrop impact and surface runoff. The RUSLE, however, does not explicitly represent the fundamental processes of detachment, deposition, and transport by rainfall and runoff, but represents the effects of these processes on soil loss. The RUSLE is based on 6 factors, which are also represented in the USLE:

$$
\mathrm{A}=\mathrm{R} \text { K L S C P }
$$

where: $\mathrm{A}=$ average annual soil loss, $\mathrm{R}=$ rainfall-runoff erosivity factor, $\mathrm{K}=$ soil erodibility factor, $\mathrm{L}=$ slope length factor, $\mathrm{S}=$ slope steepness factor, $\mathrm{C}=$ cover-management factor, and $\mathrm{P}=$ supporting practices factor. Soil loss (erosion rate) is computed by substituting values for each RUSLE factor to represent conditions at a specific site. Detailed discussions of the 6 components may be found in Renard et al. (1997).

Renard and Simanton (1990) evaluated the USLE and RUSLE predictions with measured soil loss from 17 rangeland sites in 7 western states. The simulation experiments consisted of natural vegetation and 2 altered treatments: 1) clipping vegetation only, and 2) removing all litter, vegetation, and soil surface erosion pavement (bare plots). On bare, clipped, and natural plots combined, coefficients of determination $\left(r^{2}\right)$ between the RUSLE and measured soil loss $\left(r^{2}=0.66\right)$ were higher compared to the USLE $\left({ }^{2}=0.62\right)$. On clipped and natural plots, $r^{2}$ between the RUSLE and measured soil loss $\left(r^{2}=0.36\right)$ were higher compared to the USLE $\left(r^{2}=0.08\right)$. When bare plots were included with the other 2 treatments, $\mathrm{r}^{2}$ between the USLE and 
RUSLE predicted and field measured soil loss improved; i.e., the bare plots produced more soil loss thus improving the "best fitted" prediction line. The bare plot treatment may represent the "worst case scenario" encountered; however, this situation is not a common occurrence on rangelands. Even after wildfire, root structures remain intact in the soil surface, which help stabilize the soil surface even when live surface cover is gone. Only after severe wind and water erosion and little plant regrowth over more than 1 growing season, would the bare treatment begin to become a reality.

Using Johnson and Gordon's (1988) sagebrush-grassland rainfall simulation and erosion data from the Reynold's Experimental Watershed, Benkobi et al. (1994) evaluated the RUSLE soil loss predictions using a refined RUSLE surface cover subfactor. The RUSLE soil loss was correlated with slope steepness and length $(r=0.90)$, vegetation cover $(r=-0.88)$, random roughness $(r=-0.68)$, root biomass $(\mathrm{r}=-0.50)$, and rock cover $(\mathrm{r}=$ -0.42 ). Coefficients of determination comparing field measured soil loss with the refined RUSLE model were 0.81 for dry and 0.50 for the wet simulation treatments. Using the unrefined RUSLE, $r^{2}=0.67$ for the dry treatment and $r^{2}=0.14$ for the moist treatment. Their conclusion was that use of the refined surface cover subfactor method increased accuracy; however, the RUSLE still underpredicted actual amounts of soil loss for the sagebrush/grassland sites. The objective of this study is to compare the USLE and RUSLE (version 1.06) soil loss estimates with observed soil loss from rainfall simulation studies conducted on a large and diverse set of rangeland community types.

\section{Procedures and Methods}

\section{Field Methodology}

In 1990, the NRCS established the National Range Study Team (NRST), which was a cooperative effort between the NRCS and the USDA-Agricultural Research Service (ARS). The purpose of the team was to collect field data that would expand the database for development and implementation of the WEPP and other rangeland models within the NRCS. The study was modeled (using same simulator design and field methodology) from the original ARS-Southwest Watershed Research Center rangeland simulation experiments conducted during 1987-1988 (Renard and Simanton 1990); however, additional sampling of vegetation and soils were included.

Twenty-two sites (6 plots per site), from 8 states in the NRST data set were used in this study (Table 1). Summaries of plant composition, soils, hydrology, erosion data, and management history are published in USDA (1998) and Pierson et al. (2002). This study data set represents a total of 396 rainfall simulation runs. The original NRST data set included 2 sites each from Utah and California, but were not used in this analysis because the verywet run simulations were not conducted. Only natural vegetated plots were used in this study (no artificial soil altering treatments such as rototilling; scalping; or removing vegetation, litter, organic layer, or the $\mathrm{O}$ horizon). Site selection by the NRST was based on benchmark soils and rangeland community types. Each site was selected because it represented a major soil type within the selected Major Land Resource Area (MLRA). To insure soil uniformity at each study site, 22 pedons were examined and described morphologically at $7.6 \mathrm{~m}$ intervals around the perimeter of the study site to a depth of $0.5 \mathrm{~m}$. Study sites were located on slopes between $3-12 \%$. Five soil pedon descriptions and samples were taken on each site. These plots were chosen to represent dominant and minor soil conditions occurring at the plot level.

The rainfall simulation technology used by the NRST was developed by Swanson (1965). The NRST simulator was trailermounted and has ten, $7.6 \mathrm{~m}$ booms radiating from a central stem. The arms support $30 \mathrm{~V}$-jet 80100 nozzles positioned at various distances from the stem. Half of the nozzles can be opened or closed by solenoid valves to attain target simulated rainfall intensities of $65 \mathrm{~mm} / \mathrm{hr}$ ( 15 nozzles open) or $130 \mathrm{~mm} / \mathrm{hr}$ (30 nozzles open). Rainfall was simulated uniformly over a $15 \mathrm{~m}$ diameter area where two $(3.05 \mathrm{x}$ $10.7 \mathrm{~m}$ ) steel walled plots (long axis parallel to the slope) were located on each side of the simulator. Three rainfall simulation treatment rates were sequentially applied during the growing season: 1) dry antecedent moisture, at an application rate of $65 \mathrm{~mm} / \mathrm{hr}$ until runoff equilibrium (denoted the dry run); 2) wet antecedent moisture, 24 hours later, at $65 \mathrm{~mm} / \mathrm{hr}$ until runoff equilibrium (wet run); and 3 ) verywet antecedent moisture, 30-min after the end of the wet application at $65 \mathrm{~mm} / \mathrm{hr}$ (phase 1) until runoff equilibrium, 130 $\mathrm{mm} / \mathrm{hr}$ (phase 2) until runoff equilibrium, and $65 \mathrm{~mm} / \mathrm{hr}$ (phase 3) until final runoff equilibrium (very-wet run). Simulator rainfall energy is $77 \%$ of natural rainfall when the simulator pressure and rainfall application rate using the $\mathrm{V}$-jet 80100 nozzles are held constant at $65 \mathrm{~mm} / \mathrm{hr}$ (Simanton et al. 1991). The same pressure in the V-jet 80100 nozzles is used for the very-wet treatment; however, 30 nozzles are used instead of 15 . The coefficient of variation of rainfall spatial distribution over the plots is $<10 \%$ (Simanton et al. 1987, Weltz et al. 1997). One recording raingage was placed between the paired plots to measure rainfall intensity. Six stationary gauges were also located in each plot to measure total applied rainfall.

Runoff troughs attached to the plot cutoff wall drained into drop-box weirs (Bonta 1998). Runoff water depths through small super critical flumes was measured using a pressure transducer bubbler gauge on each plot. Calibration curves allowed conversion of instantaneous depth to flow rate. Sediment sampling intervals were dependent on hydrograph curve dynamics, with 1-2 minute intervals between samples on the rising and falling portions of the hydrograph. Sediment concentrations were determined by adding a flocculating agent to each sample, and then decanting as much water as possible from the pre-weighed sample bottle, oven dried at $105^{\circ}$ and reweighed to the nearest $0.01 \mathrm{~g}$. Observed soil loss $\left(\mathrm{kg} / \mathrm{m}^{2}\right)$ from the dry, wet, and very-wet rainfall simulation treatments were used in this study. The total sum of these 3 rainfall simulation treatments is denoted as the pooled data set.

\section{USLE and RUSLE Components}

Predicted soil loss was calculated via SAS (SAS 1999), by individual plot, from the 6 component factors in USLE and RUSLE. Both models were programmed in SAS to facilitate calculation of soil loss and to perform the analysis in 1 package. The SAS program outputs for the RUSLE component factors were verified using the RUSLE. The energy-times-intensity factor (EI) (Renard et al. 1997) was calculated using the Brown and Foster (1987) unit energy equation for the dry, wet, very-wet rainfall simulation treatments and pooled data. Since the simulator rainfall energy is $77 \%$ of natural rainfall, the EI value was adjusted for all simulation runs. The LS for the USLE was determined from Wischmeier and Smith (1978); whereas, the RUSLE was used to calculate LS using percent slope and length of the plot for 1 overland flow element. A support practice value $(\mathrm{P})$ of 1.0 was used throughout this study. Two K factors were alternately 
Table 1. Summary of descriptive information for the National Range Study Team sites.

\begin{tabular}{|c|c|c|c|c|c|}
\hline $\begin{array}{l}\text { Site, } \\
\text { State }\end{array}$ & $\begin{array}{l}\text { Rangeland formation, } \\
\text { Cover type, Range site }\end{array}$ & $\begin{array}{l}\text { Soil series, Avg. surface } \\
\text { texture for the site, Avg. } \\
\text { slope, Soil taxonomic } \\
\text { classification }\end{array}$ & $\begin{array}{l}\text { Major Land } \\
\text { Resource Area } \\
\text { (MLRA) }\end{array}$ & $\begin{array}{l}\text { Annual } \\
\text { precip. }\end{array}$ & $\begin{array}{c}\text { Dominant species \% comp. (By wt. } \\
\text { descending order) }\end{array}$ \\
\hline $\begin{array}{l}\text { B1- } \\
\text { Nebr. }\end{array}$ & $\begin{array}{l}\text { Tallgrass prairie, } \\
\text { Bluestem prairie, Loamy }\end{array}$ & $\begin{array}{l}\text { Burchard, loam, } 10 \% \\
\text { Fine-loamy, mixed, mesic } \\
\text { Typic Argiudolls }\end{array}$ & $\begin{array}{l}\text { 106, Nebraska } \\
\text { and Kansas } \\
\text { Loess-Drift Hills }\end{array}$ & $\begin{array}{l}(\mathrm{cm}) \\
64-86\end{array}$ & $\begin{array}{l}\text { 1-Kentucky bluegrass (Poa pratensis L.) } \\
\text { 2-Dandelion (Taraxacum officinale G.H. } \\
\text { Weber ex Wiggers) } \\
\text { 3-Alsike clover (Trifolium hybridum L.) }\end{array}$ \\
\hline $\begin{array}{l}\text { B2- } \\
\text { Nebr. }\end{array}$ & $\begin{array}{l}\text { Tallgrass prairie, } \\
\text { Bluestem prairie, Loamy }\end{array}$ & $\begin{array}{l}\text { Burchard, loam, } 11 \% \\
\text { Fine-loamy, mixed, mesic } \\
\text { Typic Argiudolls }\end{array}$ & $\begin{array}{l}\text { 106, Nebraska } \\
\text { and Kansas } \\
\text { Loess-Drift Hills }\end{array}$ & $64-86$ & $\begin{array}{l}\text { 1-Primrose (Primula spp.) } \\
\text { 2-Porcupinegrass [Hesperostipa spartea (Trin.) } \\
\text { Barkworth] } \\
\text { 3-Big bluestem (Andropogon gerardii Vitman) }\end{array}$ \\
\hline C1-Tex. & $\begin{array}{l}\text { Shortgrass prairie, } \\
\text { Blue grama-buffalograss, } \\
\text { Deep Hardland }(25-34)\end{array}$ & $\begin{array}{l}\text { Olton, loam, } 3 \% \\
\text { Fine, mixed, thermic, } \\
\text { Aridic Paleustolls }\end{array}$ & $\begin{array}{l}\text { 77, Southern High } \\
\text { Plains }\end{array}$ & $41-53$ & $\begin{array}{l}\text { 1-Blue grama [Bouteloua gracilis (Willd. ex } \\
\text { Kunth) Lag. Ex Griffiths] } \\
\text { 2-Buffalograss [Buchloe dactyloides (Nutt.) } \\
\text { Engelm] } \\
\text { 3-Prickly pear cactus (Opuntia polyacantha } \\
\text { Haw.) }\end{array}$ \\
\hline $\begin{array}{l}\text { C2- } \\
\text { Tex. }\end{array}$ & $\begin{array}{l}\text { Shortgrass prairie, } \\
\text { Blue grama-buffalograss, } \\
\text { Deep Hardland (25-34) }\end{array}$ & $\begin{array}{l}\text { Olton, loam, } 2 \% \\
\text { Fine, mixed, thermic, } \\
\text { Aridic Paleustolls }\end{array}$ & $\begin{array}{l}\text { 77, Southern High } \\
\text { Plains }\end{array}$ & $41-53$ & $\begin{array}{l}\text { 1-Blue grama } \\
\text { 2-Buffalograss } \\
\text { 3-Prickly pear cactus }\end{array}$ \\
\hline $\begin{array}{l}\text { E1-. } \\
\text { Kans. }\end{array}$ & $\begin{array}{l}\text { Tallgrass prairie, } \\
\text { Bluestem prairie, Loamy } \\
\text { Upland }\end{array}$ & $\begin{array}{l}\text { Martin, silty clay loam, } 5 \% \\
\text { Fine, smectic, mesic, Typic } \\
\text { Hapuderts }\end{array}$ & 76, Bluestem Hills & 86 & $\begin{array}{l}\text { 1-Annual broomweed [Amphiachyris } \\
\text { dracunculoides (DC.) Nutt.] } \\
\text { 2-Missouri goldenrod (Solidago missouriensis } \\
\text { Nutt.) } \\
\text { 3-Tall dropseed [Sporobolus compositus (Poir.) } \\
\text { Merr.] }\end{array}$ \\
\hline $\begin{array}{l}\text { E2- } \\
\text { Kans. }\end{array}$ & $\begin{array}{l}\text { Tallgrass prairie, } \\
\text { Bluestem prairie, } \\
\text { Loamy Upland }\end{array}$ & $\begin{array}{l}\text { Martin, silty clay loam, } 5 \% \\
\text { Fine, smectic, mesic, Typic } \\
\text { Hapuderts }\end{array}$ & 76, Bluestem Hills & 86 & $\begin{array}{l}\text { 1-Little bluestem [Schizachyrium scoparium } \\
\quad \text { (Michx.) Nash] } \\
\text { 2-Big bluestem } \\
\text { 3-Indiangrass [Sorghastrum nutans (L.) Nash] }\end{array}$ \\
\hline $\begin{array}{l}\text { E3- } \\
\text { Kans. }\end{array}$ & $\begin{array}{l}\text { Tallgrass prairie, } \\
\text { Bluestem prairie, } \\
\text { Loamy Upland }\end{array}$ & $\begin{array}{l}\text { Martin, silty clay loam, } 3 \% \\
\text { Fine, smectic, mesic, Typic } \\
\text { Hapuderts }\end{array}$ & 76, Bluestem Hills & 86 & $\begin{array}{l}\text { 1-Buffalograss } \\
\text { 2-Sideoats grama [Bouteloua curtipendula } \\
\text { (Michx.) Torr.] } \\
\text { 3-Little bluestem }\end{array}$ \\
\hline $\begin{array}{l}\text { F1 } \\
\text { Colo. }\end{array}$ & $\begin{array}{l}\text { Northern mixed prairie, } \\
\text { Blue grama-buffalograss } \\
\text { Loamy Plains }\end{array}$ & $\begin{array}{l}\text { Stoneham, loam, } 7 \% \\
\text { fine-loamy, mixed, mesic, } \\
\text { Aridic Haplustalfs }\end{array}$ & $\begin{array}{l}67, \text { Central } \\
\text { High Plains }\end{array}$ & $28-39$ & $\begin{array}{l}\text { 1-Blue grama-buffalograss, } \\
\text { 2-Western wheatgrass [Pascopyrum smithii } \\
\text { (Rydb.) A. Löve] } \\
\text { 3-Buffalograss }\end{array}$ \\
\hline $\begin{array}{l}\text { F2- } \\
\text { Colo. }\end{array}$ & $\begin{array}{l}\text { Northern mixed prairie, } \\
\text { Blue grama-buffalograss, } \\
\text { Loamy Plains }\end{array}$ & $\begin{array}{l}\text { Stoneham, fine } \\
\text { sandy loam, } 8 \% \text { fine- } \\
\text { loamy, mixed, mesic, } \\
\text { Aridic Haplustalfs }\end{array}$ & $\begin{array}{l}\text { 67, Central High } \\
\text { Plains }\end{array}$ & $28-39$ & $\begin{array}{l}\text { 1-Blue grama } \\
\text { 2-Sun sedge [Carex inops Bailey ssp. } \\
\text { heliophila (Mackenzie) Crins] } \\
\text { 3-Bottlebrush squirreltail [Elymus elymoides } \\
\quad \text { (Raf.) Swezey] }\end{array}$ \\
\hline $\begin{array}{l}\text { F3- } \\
\text { Colo. }\end{array}$ & $\begin{array}{l}\text { Northern mixed prairie, } \\
\text { Blue grama-buffalograss, } \\
\text { Loamy Plains }\end{array}$ & $\begin{array}{l}\text { Stoneham, loam, } 7 \% \\
\text { fine-loamy, mixed, mesic, } \\
\text { Aridic Haplustalfs }\end{array}$ & $\begin{array}{l}67, \text { Central } \\
\text { High Plains }\end{array}$ & $28-39$ & $\begin{array}{l}\text { 1-Buffalograss } \\
\text { 2-Blue grama } \\
\text { 3-Prickly pear cactus }\end{array}$ \\
\hline $\begin{array}{l}\text { G1- } \\
\text { Wyo. }\end{array}$ & $\begin{array}{l}\text { Northern mixed prairie, } \\
\text { Wheatgrass-grama- } \\
\text { needlegrass, Loamy }\end{array}$ & $\begin{array}{l}\text { Kishona, vf sandy loam, } 7 \% \\
\text { Fine-loamy, mixed } \\
\text { (calcareous), mesic Ustic } \\
\text { Torriorthents }\end{array}$ & $\begin{array}{l}\text { 60A, Pierre Shale } \\
\text { Plains and Badlands }\end{array}$ & $25-36$ & $\begin{array}{l}\text { 1-Prickly pear cactus } \\
\text { 2-Needle-and-thread [Hesperostipa comata } \\
\text { (Trin. \& Rupr.) Barkworth] } \\
\text { 3-Threadleaf sedge (Carex filifolia Nutt.) }\end{array}$ \\
\hline $\begin{array}{l}\text { G2- } \\
\text { Wyo. }\end{array}$ & $\begin{array}{l}\text { Northern mixed prairie, } \\
\text { Wheatgrass-grama- } \\
\text { needlegrass, Loamy }\end{array}$ & $\begin{array}{l}\text { Kishona, clay loam, } 8 \% \\
\text { Fine-loamy, mixed } \\
\text { (calcareous), mesic Ustic } \\
\text { Torriorthents }\end{array}$ & $\begin{array}{l}\text { 60A, Pierre Shale } \\
\text { Plains and Badlands }\end{array}$ & $25-36$ & $\begin{array}{l}\text { 1-Cheatgrass (Bromus tectorum L.) } \\
\text { 2-Needle-and-thread } \\
\text { 3-Blue grama }\end{array}$ \\
\hline
\end{tabular}

Table 1 continued on page $x x x$. 
Table 1. Continued.

\begin{tabular}{|c|c|c|c|c|c|}
\hline $\begin{array}{l}\text { Site, } \\
\text { State }\end{array}$ & $\begin{array}{l}\text { Rangeland formation, } \\
\text { Cover type, Range site }\end{array}$ & $\begin{array}{l}\text { Soil series, Avg. surface } \\
\text { texture for the site, Avg. } \\
\text { slope, Soil taxonomic } \\
\text { classification }\end{array}$ & $\begin{array}{l}\text { Major Land } \\
\text { Resource Area } \\
\text { (MLRA) }\end{array}$ & $\begin{array}{l}\text { Annual } \\
\text { precip. }\end{array}$ & $\begin{array}{c}\text { Dominant species \% comp. (By wt. } \\
\text { descending order) }\end{array}$ \\
\hline $\begin{array}{l}\text { G3- } \\
\text { Wyo. }\end{array}$ & $\begin{array}{l}\text { Northern mixed prairie, } \\
\text { Wheatgrass-grama- } \\
\text { needlegrass, Loamy }\end{array}$ & $\begin{array}{l}\text { Kishona, vf sandy loam, } 7 \% \\
\text { Fine-loamy, mixed } \\
\text { (calcareous), mesic Ustic } \\
\text { Torriorthents }\end{array}$ & $\begin{array}{l}\text { 60A, Pierre Shale } \\
\text { Plains and Badlands }\end{array}$ & $\begin{array}{l}(\mathrm{cm}) \\
25-36\end{array}$ & $\begin{array}{l}\text { 1-Needle-and-thread } \\
\text { 2-Threadleaf sedge } \\
\text { 3-Blue grama }\end{array}$ \\
\hline $\begin{array}{l}\text { H1- } \\
\text { N.Dak. }\end{array}$ & $\begin{array}{l}\text { Northern mixed prairie, } \\
\text { Prairie sandreed- } \\
\text { needlegrass, Sandy }\end{array}$ & $\begin{array}{l}\text { Parshall, sandy loam, } 12 \% \\
\text { Coarse-loamy, mixed, Pachic } \\
\text { Haploborolls }\end{array}$ & $\begin{array}{l}\text { 54, Rolling Soft } \\
\text { Shale Plain }\end{array}$ & 38 & $\begin{array}{l}\text { 1-Needle-and-thread } \\
\text { 2-Prairie sandreed [Calamovilfa longifolia } \\
\text { (Hook.) Scribn.] } \\
\text { 3-Sedge (Carex spp.) }\end{array}$ \\
\hline $\begin{array}{l}\text { H2- } \\
\text { N.Dak. }\end{array}$ & $\begin{array}{l}\text { Northern mixed prairie, } \\
\text { Prairie sandreed- } \\
\text { needlegrass, Sandy }\end{array}$ & $\begin{array}{l}\text { Parshall, fine sandy loam, } \\
11 \% \text { Coarse-loamy, mixed, } \\
\text { Pachic Haploborolls }\end{array}$ & $\begin{array}{l}\text { 54, Rolling Soft } \\
\text { Shale Plain }\end{array}$ & 38 & $\begin{array}{l}\text { 1-Clubmoss (Lycopodium dendroideum } \\
\quad \text { Michx.) } \\
\text { 2-Sedge } \\
\text { 3-Crocus (Anemone patens } \mathrm{L} . \text {.) }\end{array}$ \\
\hline $\begin{array}{l}\text { H3- } \\
\text { N.Dak. }\end{array}$ & $\begin{array}{l}\text { Northern mixed prairie, } \\
\text { Prairie sandreed- } \\
\text { needlegrass, Sandy }\end{array}$ & $\begin{array}{l}\text { Parshall, sandy loam, } 10 \% \\
\text { Coarse-loamy, mixed, } \\
\text { Pachic Haploborolls }\end{array}$ & $\begin{array}{l}54 \text {, Rolling Soft } \\
\text { Shale Plain }\end{array}$ & 38 & $\begin{array}{l}\text { 1-Sedge } \\
\text { 2-Blue grama } \\
\text { 3-Clubmoss }\end{array}$ \\
\hline $\begin{array}{l}\text { I1- } \\
\text { Wyo. }\end{array}$ & $\begin{array}{l}\text { Sagebrush steppe, } \\
\text { Sagebrush-grass, Loamy }\end{array}$ & $\begin{array}{l}\text { Forkwood, loam, } 10 \% \\
\text { Fine-loamy, mixed mesic } \\
\text { Aridic Argiustolls }\end{array}$ & $\begin{array}{l}\text { 58B, Northern } \\
\text { Rolling High } \\
\text { Plains, Southern Part }\end{array}$ & $25-36$ & $\begin{array}{l}\text { 1-Wyoming big sagebrush (Artemisia } \\
\text { tridentata Nutt. ssp.wyomingensis Beetle \& } \\
\text { Young) } \\
\text { 2- Prairie junegrass [Koeleria macrantha } \\
\text { (Ledeb.) J.A. Schultes] } \\
\text { 3- Western wheatgrass }\end{array}$ \\
\hline $\begin{array}{l}\text { I2- } \\
\text { Wyo. }\end{array}$ & $\begin{array}{l}\text { Sagebrush steppe, } \\
\text { Sagebrush-grass, Loamy }\end{array}$ & $\begin{array}{l}\text { Forkwood, loamy, } 7 \% \\
\text { Fine-loamy, mixed mesic } \\
\text { Aridic Argiustolls }\end{array}$ & $\begin{array}{l}\text { 58B, Northern } \\
\text { Rolling High } \\
\text { Plains, Southern Part }\end{array}$ & $25-36$ & $\begin{array}{l}\text { 1-Western wheatgrass } \\
\text { 2-Bluebunch wheatgrass [Pseudoroegneria } \\
\text { spicata (Pursh) A. Löve] } \\
\text { 3-Prairie junegrass }\end{array}$ \\
\hline J1-Id. & $\begin{array}{l}\text { Sagebrush steppe, } \\
\text { Mountain big sagebrush, } \\
\text { Loamy (16-22) }\end{array}$ & $\begin{array}{l}\text { Robin, silt loam, } 8 \% \\
\text { Fine-silty, mixed, Cryic } \\
\text { Pachic Paleborolls }\end{array}$ & $\begin{array}{l}\text { 13, Eastern Idaho } \\
\text { Plateaus }\end{array}$ & $41-56$ & $\begin{array}{l}\text { 1-Mountain big sagebrush [Artemisia } \\
\text { tridentata Nutt. var.vaseyana (Rydb.) } \\
\text { Boivin] } \\
\text { 2-Letterman needlegrass [Achnatherum } \\
\text { lettermanii (Vasey) Barkworth] } \\
\text { 3- Sandberg bluegrass (Poa secunda J. Presl) }\end{array}$ \\
\hline J2-Id. & $\begin{array}{l}\text { Sagebrush steppe, } \\
\text { Mountain big sagebrush, } \\
\text { Loamy (16-22) }\end{array}$ & $\begin{array}{l}\text { Robin, silt loam, } 8 \% \\
\text { Fine-silty, mixed, Cryic } \\
\text { Pachic Paleborolls }\end{array}$ & $\begin{array}{l}\text { 13, Eastern Idaho } \\
\text { Plateaus }\end{array}$ & $41-56$ & $\begin{array}{l}\text { 1-Letterman needlegrass } \\
\text { 2-Sandberg bluegrass } \\
\text { 3-Prairie junegrass }\end{array}$ \\
\hline $\begin{array}{l}\text { K1- } \\
\text { Ariz. }\end{array}$ & $\begin{array}{l}\text { Shrub steppe-shortgrass } \\
\text { Blue grama-galleta, } \\
\text { Loamy Upland }\end{array}$ & $\begin{array}{l}\text { Lonti, sandy loam, } 5 \% \\
\text { Fine, mixed, mesic } \\
\text { Ustic Haplargids }\end{array}$ & $\begin{array}{l}\text { 35, Colorado and } \\
\text { Green River Plateaus }\end{array}$ & $30-41$ & $\begin{array}{l}\text { 1-Blue grama } \\
\text { 2-Goldenweed (Haploppaus spp.) } \\
\text { 3-Ring muhly [Muhlenbergia torreyi (Kunth) } \\
\text { A.S. Hitchc. ex Bush] }\end{array}$ \\
\hline $\begin{array}{l}\text { K2- } \\
\text { Ariz. }\end{array}$ & $\begin{array}{l}\text { Shrub steppe, shortgrass } \\
\text { Blue grama-galleta, } \\
\text { Loamy Upland }\end{array}$ & $\begin{array}{l}\text { Lonti, sandy loam, } 4 \% \\
\text { Fine, mixed, mesic } \\
\text { Ustic Haplargids }\end{array}$ & $\begin{array}{l}\text { 35, Colorado and } \\
\text { Green River Plateaus }\end{array}$ & $30-41$ & $\begin{array}{l}\text { 1-Rubber rabbitbrush [Ericameria nauseosa } \\
\text { (Pallas ex Pursh) Nesom \& Baird] } \\
\text { 2- Blue grama } \\
\text { 3-Threeawn (Aristida } \mathrm{spp} .)\end{array}$ \\
\hline
\end{tabular}

used: the NRCS assigned $\mathrm{K}$ value for the soil type $\left(\mathrm{K}_{\mathrm{NRCS}}\right)$, and nomograph $\mathrm{K}$ $\left(\mathrm{K}_{\mathrm{NOMO}}\right)$ calculated from the soil-erodibility nomograph equation (Wischmeier and Smith 1978). Data for the nomograph (percent silt, very fine sand, clay, organic matter, soil structure, and profile permeability class) were determined from soil profile descriptions and samples collected at each plot. Complete soil characterization (physical and chemical) was per- formed by the NRCS National Soil Survey Laboratory in Lincoln, Nebr. Laboratory procedures are given in detail in the Soil Survey Laboratory Methods Manual (USDA-SCS 1992).

The study plot USLE cover management factors $(\mathrm{C})$ were obtained from Table 10 of USDA-Agriculture Handbook No. 537 (Wischmeier and Smith 1978). The RUSLE C factor was calculated using 2 strategies $\left(\mathrm{C}_{\text {table }}\right.$ and $\left.\mathrm{C}_{\text {field }}\right)$. The RUSLE
$\mathrm{C}_{\text {table }}$ value was obtained by "best fitting" the study plot vegetation type with values given in Tables 5-4 (ratio of effective root mass to annual site production potential, $\mathrm{n}_{\mathrm{i}}$ ) and 5-6 (soil surface roughness, $\mathrm{Ru})($ Renard et al. 1997). For example, site $\mathrm{B} 1$, plot 1 (tall grass prairie ecotype) is dominated by Kentucky bluegrass (Poa pratensis L.), dandelion (Taraxacum officinale G.H. Weber ex Wiggers), and alsike clover (Trifolium hybridum L.)(Table 1). 
The site now represents short sod forming species (the vegetation type most closely represented in RUSLE is the "pasture" designation, since Kentucky bluegrass is an introduced cool season species. Field plot data was used for the other $\mathrm{C}$ parameters: percent vegetation canopy cover, rock cover, ground cover, and effective raindrop fall height. The RUSLE $\mathrm{C}_{\text {field }}$ value is based on using actual field measured values to calculate $n_{i}$ and $R_{u}$. Field plot data (as was $\mathrm{C}_{\text {table }}$ ) was used to parameterize percent vegetation canopy cover, rock cover, ground cover, and effective raindrop fall height.

The RUSLE cover management factors were calculated using the $4 \mathrm{C}$ subfactor equations in Renard et al. (1997). The RUSLE C subfactor calculations were programmed in SAS using the equations cited in Renard et al. (1997) and verified using RUSLE. The 4 subfactors are:1) canopy cover subfactor (CC);2) surface cover subfactor (SC); 3) surface roughness subfactor (SR); and 4) the prior use subfactor (PLU).

Calculation of the $\mathrm{CC}$ subfactor requires the fraction of land surface covered by canopy and the distance that raindrops fall after interception by the plant canopy. Plot canopy cover was determined from 49 pinpoints on 10 separate transects $(490$ points) horizontally traversing each plot. Canopy cover was determined as the first aerial contact point by plant life form (shrub, half-shrub, forb, grass, cactus, or standing dead). In the RUSLE, effective raindrop fall height is defined as the average fall height of a raindrop which has been intercepted by the canopy. Effective fall height was determined from the dominant plant in each plot.

The SC subfactor was calculated from the percentage ground surface cover, surface roughness, and the empirical coefficient (b), which is the effectiveness of surface cover (rock and residue) in controlling erosion. Renard et al. (1997) gives recommendations for " $b$ " which is dependent on soil type, slope steepness, and land use. A "b" value of 0.035 was used for medium and coarse textured soils with slope ranges of $3-8 \%$. A "b" value of 0.045 was used for shrub communities and for relatively coarse rangeland soils with low annual rainfall. Study plot ground surface measurements were recorded directly after the canopy cover measurement-as the pin was lowered to the surface of the ground, ground surface cover characteristics were recorded (bare soil, litter, vegetative residue, plant basal cover, cryptogams, gravel and rocks). At each pin- point, $\mathrm{R}_{\mathrm{u}}$ was determined by measuring ground surface height above an arbitrary reference line on the point frame. The standard deviation of heights were calculated for each of the 10 transects across the plot, then averaged to determine plot random roughness. Calculation of the SR subfactor also requires the $R_{u}$.

The PLU subfactor was calculated using total average annual site production potential, and ni. The PLU factor was calculated using root biomass at $10 \mathrm{~cm}$ soil depth from each simulation plot. Root samples were taken as follows: In each plot, after the very-wet run, 6 perpendicular transects were established at $1.5 \mathrm{~m}$ intervals starting from the bottom of the plot. Along each of these transects, a point was selected and a single $9.84 \mathrm{~cm}$ diameter, $10 \mathrm{~cm}$ deep soil core was collected. The above ground biomass was clipped from the core and discarded. The soil core was then divided into a $0-2.5 \mathrm{~cm}$ layer and a 2.5-10 cm layer. In shrub communities this sampling procedure was repeated for shrub interspace and shrub coppice areas $25 \mathrm{~cm}$ from the base of the shrub. The soil and below ground biomass samples were washed in mesh containers for 40-90 minutes until all mineral soil material was removed, then oven dried at $60^{\circ} \mathrm{C}$ for 24 hours and weighed. Average annual production was determined by clipping all vegetation by species from five $0.18 \mathrm{~m}^{2}$ quadrats per simulation plot on grassland sites and five, $0.45 \mathrm{~m}^{2}$ quadrats in shrub communities. In shrub communities, current years growth was separated from total shrub weight. Vegetation samples were oven-dried at $60^{\circ} \mathrm{C}$ for 48 hours, then weighed to determine dry weight percentage. Average annual production was calculated via the methodology outlined in the National Range and Pastureland Handbook (USDA-NRCS 1997). When actual production values are not available, Renard et al. (1997) suggest that average annual production estimates can be obtained from NRCS rangeland ecological site descriptions.

\section{Statistical Analysis}

Model efficiency $\mathrm{R}^{2}$ eff (Nash and Sutcliffe 1970) was used to evaluate USLE and RUSLE estimated soil loss with field measured soil loss for all study plot simulation runs. Model efficiency was calculated as follows:

$$
\mathrm{R}^{2} \mathrm{eff}=\frac{\sum_{i=1}^{n}\left(Q_{m i}-Q_{c i}\right)^{2}}{\sum_{i=1}^{n}\left(Q_{m i}-Q_{m}\right)^{2}}
$$

where $R^{2}$ eff = the efficiency of the model, $\mathrm{Q}_{\mathrm{mi}}=$ measured value of event $\mathrm{i}, \mathrm{Q}_{\mathrm{ci}}=$ the RUSLE computed value of event $i$, and $\mathrm{Qm}=$ the mean of the measured values. The $\mathrm{R}^{2}$ eff is the proportion of the initial variance in the measured values which is explained by the model. Initial variance is relative to the mean value of all the measured values. The $\mathrm{R}^{2}$ eff is different than the coefficient of determination $\left(r^{2}\right)$ in that it compares the measured values to a $1: 1$ line (measured $=$ predicted) rather than to a best-fitted regression line. The $R^{2}$ eff is always lower than the coefficient of determination $\left(r^{2}\right)$ and a $R^{2}$ eff value of 1 indicates that the model provided perfect prediction, and $\mathrm{R}^{2} \mathrm{eff}=0$ indicates that the sum of squares of the difference between the measured and computed values is equal to the sum of squares difference between the measured values and the mean of the measured values. Therefore, the mean value of the measured plot erosion from the data set would be as good a predictor of plot erosion as the RUSLE model. A negative value (can go to $-(\infty)$ indicates that $\mathrm{Q}_{\mathrm{m}}$ is a better predictor of $\mathrm{Q}_{\mathrm{mi}}$ than $\mathrm{Q}_{\mathrm{ci}}$. The SAS (SAS 1999) system was used to compute the $R^{2}$ eff. Residual values (measured soil loss $\bar{n}$ USLE or RUSLE predicted soil loss) were calculated and plotted to evaluate systematic patterns and variances of the error terms.

\section{Results}

\section{USLE Predicted Soil Loss}

Nash-Sutcliffe model efficiencies $\left(\mathrm{R}^{2} \mathrm{eff}\right)$ were calculated on 132 plots for the dry, wet, very wet rainfall simulation treatments and the pooled data (Table 2). Model efficiency of the USLE (w/ $\mathrm{K}_{\mathrm{NRCS}}$ and $\mathrm{K}_{\mathrm{NOMO}}$ ) was negative for the dry, wet, and very-wet simulation treatments, and the pooled data (Table 2). The negative $\mathrm{R}^{2}$ eff statistic implies that mean measured soil loss for the respective runs is a better representation of soil loss than estimated USLE values. Using the $\mathrm{K}_{\mathrm{NOMO}}$ value in the USLE calculation did not result in better predictions: the respective $\mathrm{R}^{2}$ eff values were more negative with $\mathrm{K}_{\mathrm{NOMO}}$ compared to using $\mathrm{K}_{\mathrm{NRCS}}$.

Figure 1a plots measured and USLE estimated values of soil loss for the dry, wet, and very wet runs combined (the pooled set). About $61 \%$ of the USLE predicted soil loss was higher than the field measured soil loss. Figures 2a,b,c and 3a represent plots of the residual values and predicted USLE ( $\mathrm{w} / \mathrm{K}_{\mathrm{NRCS}}$ ) for the dry, wet, 
(a)

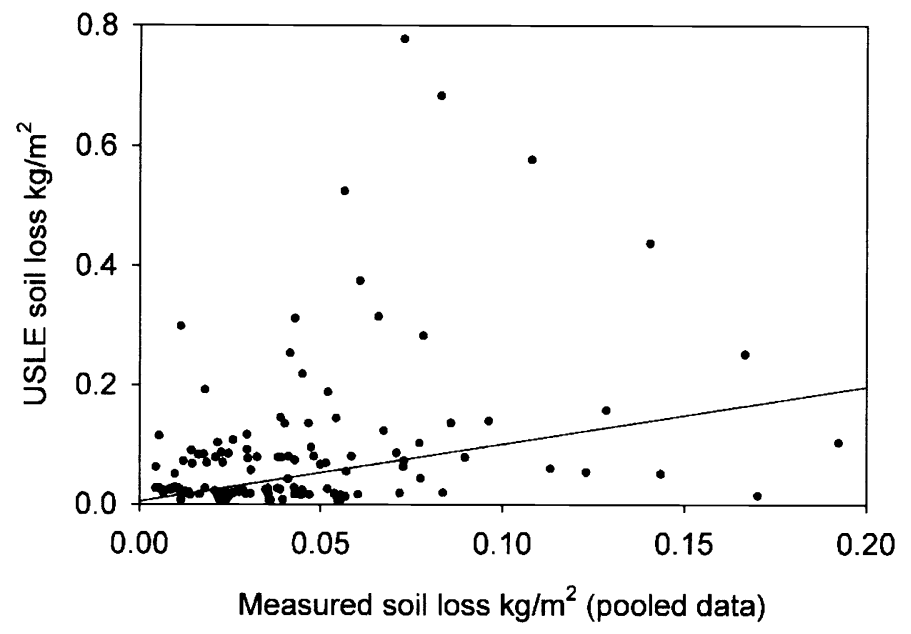

(b)

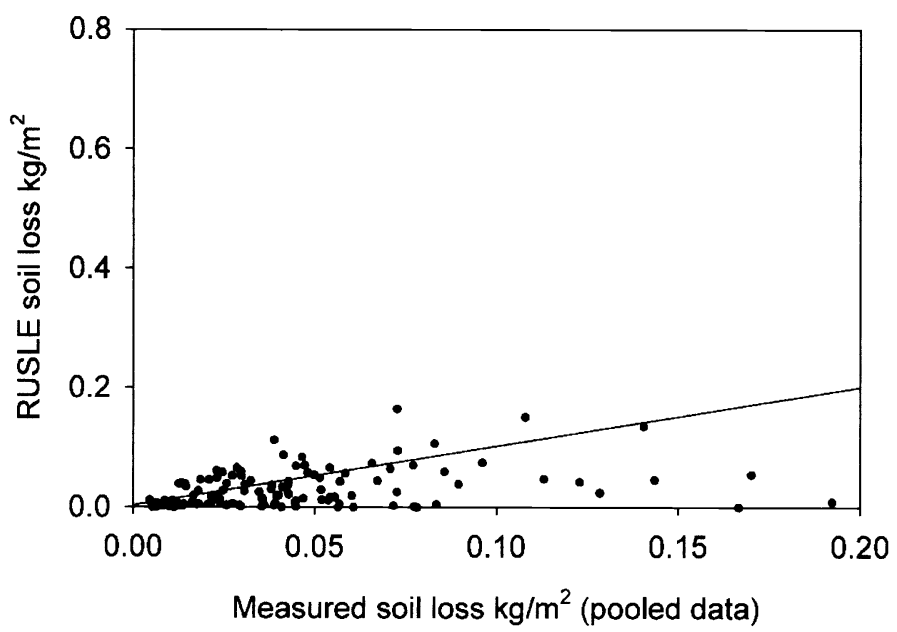

Fig. 1a. Measured soil loss (pooled from dry, wet, and very-wet rainfall simulation treatment runs) and USLE predicted soil loss. 1b) Measured soil loss (pooled) and RUSLE predicted soil loss.

very-wet, and pooled data. The trend of residuals for the 3 simulation treatment runs and the pooled data are consistent: more than half of the error variance is negative (predicted USLE soil loss is higher than measured). Percent negative error variance for the respective simulation treatments were: dry run $=70.5 \%$, wet run $=69 \%$, very-wet run $=55 \%$ ), and the error becomes increasingly negative as USLE predicted values increase (Figs. 2a,b,c, 3a).

Soil loss was greatest during the verywet run $\left(0.035 \mathrm{kgm}^{2}\right)$, followed by the dry $\left(0.011 \mathrm{~kg} / \mathrm{m}^{2}\right)$ and wet $\left(0.007 \mathrm{~kg} / \mathrm{m}^{2}\right)$ rainfall treatment simulation runs (Table 3 ). Soil loss from the very-wet simulation run was the most variable (coefficient of variation, $\mathrm{CV}=20.0 \%$ ) compared to the dry $(\mathrm{CV}=9.0 \%)$ and wet runs $(\mathrm{CV}=10.0 \%)$. The average of measured soil loss for the pooled data was $0.045 \mathrm{~kg} / \mathrm{m}^{2}$ (Table 3).
The average ratios of measured soil loss to USLE predicted ( $\mathrm{w} / \mathrm{K}_{\mathrm{NRCS}}$ ) soil loss were $0.38: 1,0.46: 1,0.60: 1,0.48: 1$ for the dry, wet, very-wet rainfall simulation treatments and pooled data, respectively. These ratios were consistent with the Johnson et al. (1984) sagebrush and shadscale studies and Simanton's et al. (1980) findings on grass-covered watersheds and some brush covered watersheds where runoff events were more numerous and of greater magnitude. In Simanton's study, USLE overpredicted soil loss on grass-covered watersheds [measured $\left(0.015 \mathrm{~kg} / \mathrm{m}^{2} / \mathrm{yr}\right)$ vs. USLE predicted $\left(0.033 \mathrm{~kg} / \mathrm{m}^{2} / \mathrm{yr}\right)$, a $0.45: 1$ ratio]. On brush covered watersheds, USLE overpredicted soil loss in years with small runoff events and underpredicted soil loss in years with large runoff events. Wilcox et al. (1989) evaluated the Modified Universal Soil Loss Equation (MUSLE) on Wyoming big sagebrush (Artemisia tridentata Nutt. ssp.wyomingensis Beetle \& Young) sites at the Reynolds Creek Experimental Watershed and observed predicted rates to be 12 and 6 times higher on 2 sites. They attributed the poor predictive capability to the fact that the slope range of the 2 sites were well beyond the range of the data base from which the USLE was designed. However, in this study, slope ranges were within the designated range for USLE (see Table 1).

\section{RUSLE Predicted Soil Loss}

Nash-Sutcliffe model efficiency of the RUSLE was negative for the wet, verywet, and pooled data (Table 2). This implies that mean measured soil loss for the respective runs are a better representation of soil loss than estimated RUSLE

Table 2. Nash Sutcliffe coefficient of model efficiency $\left(R^{2}\right.$ eff $)$ for USLE and RUSLE 1.06 estimated soil loss with field measured erosion from 3 rainfall simulation treatments (dry run, wet run, very-wet run, and pooled data).

\begin{tabular}{|c|c|c|c|c|}
\hline Model Estimated Erosion & $\begin{array}{l}\text { Dry } \\
\text { Run }\end{array}$ & $\begin{array}{l}\text { Wet } \\
\text { Run }\end{array}$ & $\begin{array}{c}\text { V-wet } \\
\text { Run }\end{array}$ & Pooled $^{1}$ \\
\hline $\mathrm{USLE} \mathrm{w} / \mathrm{K}_{\mathrm{NRCS}}{ }^{2}$ & -8.29 & -7.28 & -1.06 & -12.34 \\
\hline USLE w/ $\mathrm{K}_{\mathrm{NOMO}}{ }^{3}$ & -11.66 & -15.43 & -1.67 & -20.49 \\
\hline RUSLE $1.06 \mathrm{w} / \mathrm{C}_{\text {table }}, \mathrm{K}_{\mathrm{NRCS}}{ }^{4}$ & 0.16 & -0.05 & -0.12 & -0.33 \\
\hline RUSLE $1.06 \mathrm{w} / \mathrm{C}_{\text {table }}, \mathrm{K}_{\mathrm{NOMO}}{ }^{5}$ & 0.17 & -0.22 & -0.14 & -0.41 \\
\hline RUSLE $1.06 \mathrm{w} / \mathrm{C}_{\text {field }}, \mathrm{K}_{\mathrm{NRCS}}{ }^{6}$ & -0.74 & -0.71 & -0.07 & -1.32 \\
\hline RUSLE $1.06 \mathrm{w} / \mathrm{C}_{\text {field }}, \mathrm{K}_{\mathrm{NOMO}}{ }^{7}$ & -1.12 & -1.53 & -0.16 & -2.18 \\
\hline
\end{tabular}

${ }^{1}$ Pooled data is the composite of all three rainfall simulation runs (dry, wet, and very-wet)

${ }^{2}$ Universal soil loss equation with NRCS soil erodibility (K)

${ }^{3}$ Universal soil loss equation with nomograph soil erodibility $(\mathrm{K})$

${ }_{5}^{4}$ RUSLE 1.06 with C subfactor values from Renard et al. 1997 tables (best fit to plot), and NRCS K

${ }^{5}$ RUSLE 1.06 with C subfactor values from Renard et al. 1997 tables (best fit to plot), and nomograph K

${ }^{6}$ RUSLE 1.06 with C subfactor values from field measurements, and NRCS K

${ }^{7}$ RUSLE 1.06 with C subfactor values from field measurements, and nomograph $\mathrm{K}$ 
(a)
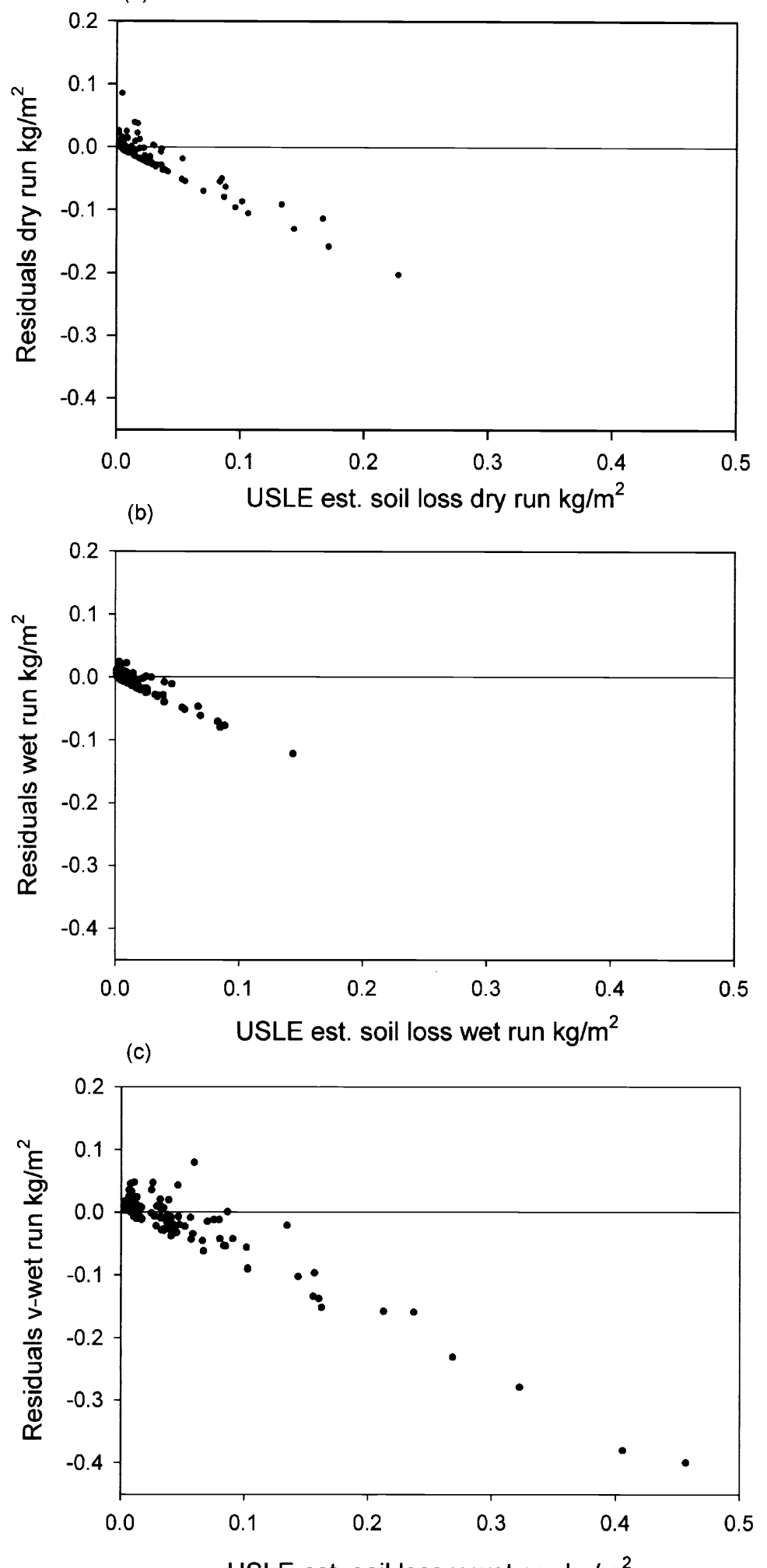

USLE est. soil loss v-wet run $\mathrm{kg} / \mathrm{m}^{2}$

Fig. 2a,b,c. USLE predicted soil loss for the dry, wet, and very-wet rainfall simulation treatments plotted against residual values (measured-predicted soil loss). soil loss. However, $2, \mathrm{R}^{2}$ eff values were positive for the dry simulation data. The Nash-Sutcliffe model efficiency of the RUSLE for the dry simulation treatment was 0.16 and 0.17 using the $C_{\text {table }}$, $\mathrm{K}_{\text {NRCS }}$ and $\mathrm{C}_{\text {table }}, \mathrm{K}_{\text {NOMO }}$ factors, respectively (Table 2 ). The $\mathrm{C}_{\text {table }}$ calculation used the Renard et al. (1997) table values $(5-4,5-6)$ for $n_{i}$ and $R_{u}$. The $R^{2}$ eff inference is that the RUSLE was a marginally better predictor of soil loss; however, when actual field measured values for ni and $R_{u}$ were used to calculate $C_{\text {field }}$, the dry simulation treatment $R^{2}$ eff's were negative (Table 2). Similarly, $\mathbf{R}^{2}$ eff for the wet, very-wet, and pooled runs were negative (Table 2).

In contrast to the USLE, the RUSLE trend was toward underprediction. The average ratio of measured soil loss to RUSLE (w/ $\mathrm{C}_{\text {table }}, \mathrm{K}_{\mathrm{NRCS}}$ ) predicted soil loss was $1.57: 1,1.75: 1$, and $2.69: 1$ for the dry, wet, and very-wet run rainfall simulation treatments, respectively. The average ratio of measured vs. RUSLE predicted soil loss for the pooled data was $1.8: 1$. In Figure 1b (pooled field measured and RUSLE predicted soil loss), about $70 \%$ of the points fall below the $1: 1$ line. In comparing figure $1 \mathrm{a}$ and $1 \mathrm{~b}$, the USLE had extreme outliers above the 1:1 line; whereas, the RUSLE did not. Figures $3 b$ and $4, a, b, c$ show a trend of increasing positive residuals for the dry $(58.2 \%)$, wet $(55.7 \%)$, very-wet $(71.4 \%)$ rainfall simulation treatments and the pooled data $(69.7 \%)$. As soil moisture and rainfall intensity increased (the very-wet simulation treatment), the RUSLE predictions become more erratic. Although the RUSLE tended to underpredict soil loss on more plots than the USLE, the maximum magnitude of positive error variance was about the same for both models (Figs $2 a, b, c$, and $4 a, b, c)$. For both the USLE and RUSLE, positive error variances never exceeded $0.13 \mathrm{~kg} / \mathrm{m}^{2}$ for the dry, wet, and very-wet rainfall simulation treatments. For the pooled data, positive error variance did not exceed $0.20 \mathrm{~kg} / \mathrm{m}^{2}$ for both models (Figs. 3a,b).

On plots where the RULSE overpredicted soil loss, the trend, much like the USLE, showed increasing negative error variance (Figs. 3b, 4a,b,c). As soil moisture and rainfall intensity increased (the very-wet simulation treatment), the RUSLE negative error variance was the greatest. Although the USLE and RULSE displayed similar linear patterns of negative error variance, the magnitude of error was less for the RUSLE. On the very-wet simulation plots, the USLE negative error 
variance reached $-0.40 \mathrm{~kg} / \mathrm{m}^{2}$; whereas, the RUSLE error never exceeded -0.06 $\mathrm{kg} / \mathrm{m}^{2}$.

\section{Discussion and Conclusions}

In this study we evaluated the USLE and RUSLE soil loss predictive capability with a rangeland data set that included a diverse cross section of rangeland plant communities. The overall $\mathrm{R}^{2}$ eff of the USLE and RUSLE using the 3 rainfall simulation treatments was negative, except for the RUSLE prediction with the dry run data (Table 2 ). The negative $\mathrm{R}^{2}$ eff indicates that the use of model predictions is worse than using mean measured soil loss from the field. Distribution of error variances (measured soil loss-USLE predicted soil loss) for the 3 rainfall simulation treatments showed a consistent trend of overprediction by USLE. Conversely, the RUSLE error variances showed a consistent trend of underpredicted soil loss among the 3 rainfall simulation treatments. As the soils on the rangeland sites became more saturated, the propensity for underprediction increased. In comparison to the USLE, the RUSLE had less error variance between field measured soil loss and RUSLE predicted soil loss.

Nearing (1998) states that an inherent phenomenon of erosion models is that they "tend to overpredict soil erosion for small measured values, and underpredict soil erosion for larger measured values. This trend appears to be consistent regardless of whether the soil erosion value of interest is for individual storms, annual totals, or average annual soil losses, and regardless of whether the model is empirical or physically based." Nearing's hypothesis is related to the inherent random components from field measurements that are not accounted for in erosion models. In studying the overall predictive nature of the USLE on rangeland using the NRST rangeland data, it appears that the USLE overestimated plots with low erosion rates. This trend was consistent for the dry, wet, and very-wet rainfall simulation treatments. On plots with higher intense rainfall $(130 \mathrm{~mm} / \mathrm{hr}$ very-wet run) and higher soil loss rates, the USLE also tended to overpredict soil loss. In summary, the prediction capability of the USLE on rangeland fit Nearing' s premise for the small measured values and for the 2 highest measured values (Fig. 1a.). The RUSLE results also tended to fit Nearing's premise on rangeland: overprediction of

(a)

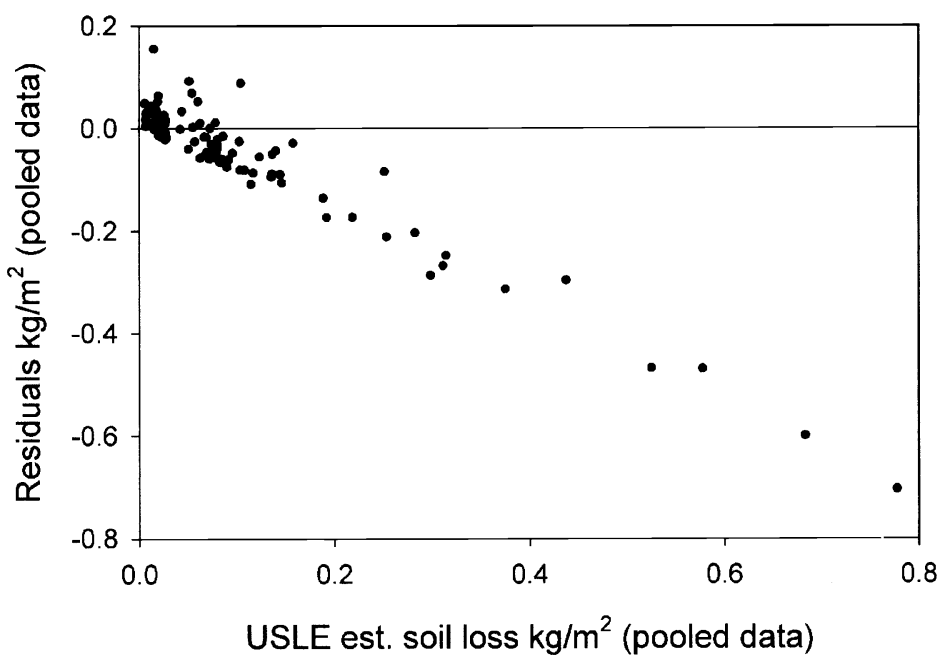

(b)

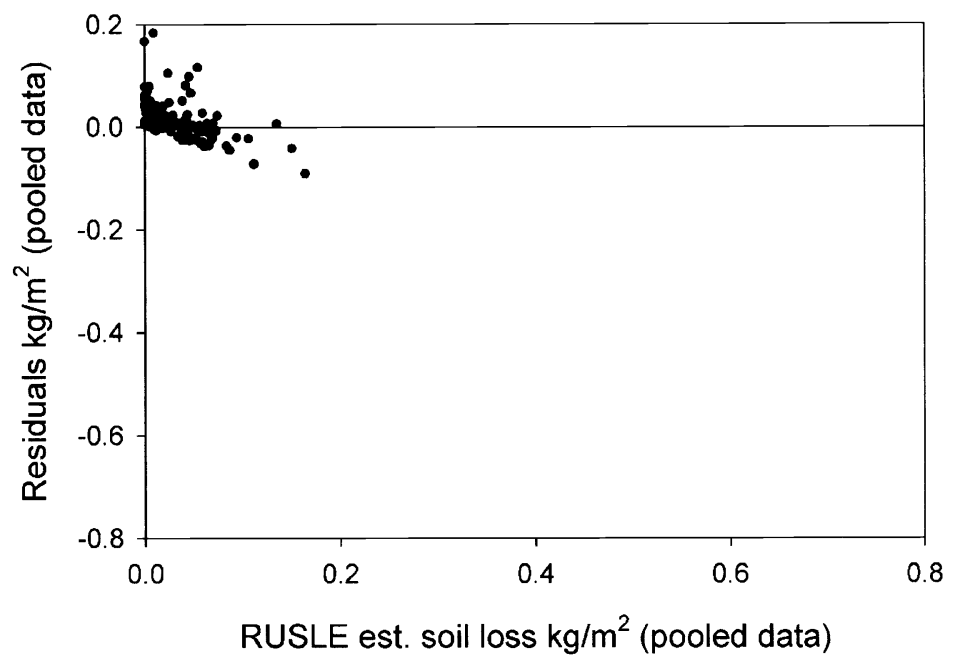

Fig. 3a. USLE predicted soil loss (pooled from the dry, wet, and very-wet rainfall simulation treatments) plotted against residual values (measured-predicted soil loss). Figure $3 \mathrm{~b}$. RUSLE predicted soil loss (pooled from the dry, wet, and very-wet rainfall simulation treatments) plotted against residual values (measured-predicted soil loss).

soil loss for the lowest measured values (dry, wet, and very-wet simulation treatments) and underprediction as observed soil loss rates increased.

We realize that there is uncertainty associated with hydrologic and erosion predictions (Beven 1987) on rangeland because the interacting plant and soil variables affecting hydrology and erosion on rangeland are very complex (Gifford 1985, Thurow 1991). In addition, we recognize the difficulty of predicting relatively low amounts soil loss on relatively undisturbed rangeland sites $(<0.5 \mathrm{t} / \mathrm{ha})$. In Renard and Simanton's (1990) study, their correlations of observed and RUSLE predicted soil loss only improved when the highly disturbed plots were added to the data set. Other rangeland hydrology studies have measured low soil loss rates on rangeland-even with substantial rainfall application rates. Hawkins (1985) states that rainstorm runoff and erosion on western rangelands and forestlands is rare, even with substantial overall precipitation input. Rangeland soil loss on natural plots (Blackburn and Skau 1974, Hart 1984, Buckhouse and Mattison 1980, Blackburn et al. 1990, Spaeth 1990); grazed plots (Gamougoun et al. 1984, McGinty et al. 
Table 3. Summary of average measured soil loss, USLE, and RUSLE predicted soil loss with residual values.

\begin{tabular}{|c|c|c|c|c|}
\hline Model Estimated Erosion & $\begin{array}{l}\text { Dry } \\
\text { Run }\end{array}$ & $\begin{array}{l}\text { Wet } \\
\text { Run }\end{array}$ & $\begin{array}{l}\text { V-wet } \\
\text { Run }\end{array}$ & Pooled $^{1}$ \\
\hline Avg. measured soil loss & 0.011 & (n. & 0.035 & 0.045 \\
\hline $\begin{array}{l}\text { USLE } w / w / \mathrm{K}_{\mathrm{NRCS}}{ }^{2} \\
\text { Residual } \\
{\text { USLE } w / \mathrm{K}_{\mathrm{NOMO}}}^{4} \\
\text { Residual }\end{array}$ & $\begin{array}{r}0.029 \\
-0.018 \\
0.030 \\
-0.019\end{array}$ & $\begin{array}{r}0.015 \\
-0.008 \\
0.016 \\
-0.009\end{array}$ & $\begin{array}{r}0.056 \\
-0.021 \\
0.058 \\
-0.023\end{array}$ & $\begin{array}{c}0.093 \\
-0.048 \\
0.10 \\
-0.055\end{array}$ \\
\hline $\begin{array}{l}\text { RUSLE w/Ctable, } \mathrm{K}_{\mathrm{NRCS}}{ }^{5} \\
\text { Residual }\end{array}$ & $\begin{array}{l}0.007 \\
0.004\end{array}$ & $\begin{array}{l}0.004 \\
0.003\end{array}$ & $\begin{array}{l}0.013 \\
0.02\end{array}$ & $\begin{array}{l}0.025 \\
0.02\end{array}$ \\
\hline $\begin{array}{l}\text { RUSLE w/Ctable, } \mathrm{K}_{\text {NOMO }}{ }^{6} \\
\text { Residual }\end{array}$ & $\begin{array}{l}0.007 \\
0.004\end{array}$ & $\begin{array}{l}0.007 \\
0.0\end{array}$ & $\begin{array}{l}0.013 \\
0.02\end{array}$ & $\begin{array}{l}0.024 \\
0.021\end{array}$ \\
\hline $\begin{array}{l}\text { RUSLE w/Cfield, } \mathrm{K}_{\mathrm{NRCS}}{ }^{7} \\
\text { Residual }\end{array}$ & $\begin{array}{l}0.003 \\
0.008\end{array}$ & $\begin{array}{l}0.003 \\
0.004\end{array}$ & $\begin{array}{l}0.007 \\
0.028\end{array}$ & $\begin{array}{l}0.005 \\
0.04\end{array}$ \\
\hline $\begin{array}{l}\text { RUSLE w/Cfield, } \mathrm{K}_{\mathrm{NOMO}}{ }^{8} \\
\text { Residual }\end{array}$ & $\begin{array}{l}0.005 \\
0.006\end{array}$ & $\begin{array}{l}0.005 \\
0.002\end{array}$ & $\begin{array}{l}0.009 \\
0.026\end{array}$ & $\begin{array}{l}0.012 \\
0.03\end{array}$ \\
\hline
\end{tabular}

${ }^{1}$ Pooled data is the composite of all 3 rainfall simulation runs (dry, wet, and very-wet)

${ }^{2}$ Universal soil loss equation with NRCS soil erodibility (K)

${ }^{3}$ Residual $=$ averaged measured soil loss-model predicted soil loss.

${ }^{4}$ Universal soil loss equation with nomograph soil erodibility $(\mathrm{K})$

${ }^{5}$ RUSLE 1.06 with C subfactor values from Renard et al. 1997 tables (best fit to plot), and NRCS K

${ }^{6}$ RUSLE 1.06 with C subfactor values from Renard et al. 1997 tables (best fit to plot), and nomograph K

${ }^{7}$ RUSLE 1.06 with C subfactor values from field measurements, and NRCS K

${ }^{8}$ RUSLE 1.06 with C subfactor values from field measurements, and nomograph $\mathrm{K}$

1979, Wood and Blackburn 1981, Warren et al. 1986); burned plots (Pierson et al. 2001); and on the watershed scale (Simanton et al. 1977, Wilcox et al. 1989) are relatively low compared to cropland (Risse et al.1993).

An important philosophical issue regarding the practical use of erosion models needs to be clarified: e.g., why attempt to model long-term average soil loss rates on rangeland (the literature shows relatively low rates on rangeland) and what is the value of this information to programs, monitoring, and resource assessments. In reality, it is the rare or unexpected storm event(s) that may cause instability in rangeland ecosystem functionality, which can compromise soil stability and hydrologic function. Resource managers should consider the probability or frequency of these types of events in conjunction with current rangeland conditions and various combinations of management. Improper management often exacerbates the destructive capacity of these rare events. In many cases, as rangeland deterioration progresses and some critical threshold has been crossed, rangeland ecosystem function can be acutely compromised (Satterlund 1972, Heede 1979, National Research Council 1994, de Soyza et al. 2000a, 2000b, Pellant et al. 2000).
There are technical and philosophical issues that relate to hydrology and erosion prediction models on rangeland. One important technical issue is the identification and integration of inherent component variables that relate to erosion and hydrology and how these variables are treated and modeled mathematically (Hanson et al. 1999). It is important that efforts be made to explore and include variables in models that help minimize the random components (the latent variables) of measured erosion that Nearing (1998) speaks about. This will require a different paradigm in modeling (Spaeth et al. 1996 a, 1996b, Pierson et al. 2002). The answer may lie in using exogenous variables which may account for latent variables that are difficult or cannot be readily identified. For example, many hydrology and erosion models commonly utilize readily measurable plant related variables such as plant cover, biomass, litter cover and amount, plant height, root biomass, and soil related variables such as bulk density, aggregate stability, porosity, organic carbon, and particle size. Spaeth et al. (1996 $\mathrm{a}, \mathrm{b})$ used ordination and gradient analysis (Gauch 1982) procedures to identify multivariate relationships between individual plants, groups of plants, soil variables and hydrologic data. A more ecological approach in recognizing plant community and soil components, both on the quantitative and qualitative level can significantly improve infiltration equations on rangeland (Spaeth et al 1996a,1996b). Individual plant species also have a profound affect on hydrology (Thomas and Young 1954, Mazurak and Conrad 1959, Dee et al. 1966, Spaeth 1990, Gutierrez-Castillo 1994); the presence of a particular plant species may represent unidentifiable latent variables (Spaeth et al. 1996a, 1996b).

Categorical or qualitative variables such as soil diagnostic features (argillic, salic, mollic . . . slickensides, duripans, fragipans); soil structural grades (weak . . . strong); structure size (coarse . . . very thin); dry and wet consistence (hard . . very friable); soil boundary distinctness (abrupt . . . gradual); boundary topography (broken . . . wavy); structure size classes (angular blocky ... . single grain); rupture resistance concepts; cementation and agents; stickiness; soil plasticity; ped surface features (black stains . . . oxide coats); pore shape and size classes; concentration kind, (clay bodies, worm casts . . . carbonate nodules); concentration shape, size, location, hardiness, and origin; soil mottles (size, class, contrast, shape, location); soil texture modifiers; soil particle coatings (organic coats . . . clay films); rock fragments (kind, roundness, size); root pans; type of biological soil crusts (lichen, moss, algae etc); soil mineral crusts; root morphology (size, class, depth, location); plant life forms (grasses ... shrubs); plant growth forms (sod forming, caespitose); plant distribution and patterns; plant and leaf architecture; and individual plant species or combinations of certain species should be considered in rangeland erosion and hydrology models. These variables can help explicate the soil-plant interactive environment and reduce unidentifiable error in empirical, statistical, and process bases models.

On rangeland, no uniform set of management guidelines fits all rangeland plant community types (Hanson et al. 1999). Resource managers are faced with synthesizing an overwhelming amount of ecological, soils, hydrology, and range management information (Spaeth et al. 2001). For this reason, rangeland resource tools that can model hydrology (infiltration, runoff, evaporation, transpiration, deep percolation, and water storage), soil loss, and soil deposition changes in response to management alternatives are greatly needed (Hanson et al. 1999). Rangeland managers would benefit greatly if a "user friendly" WEBB based rangeland hydrology and erosion decision support tool were avail- 
(a)

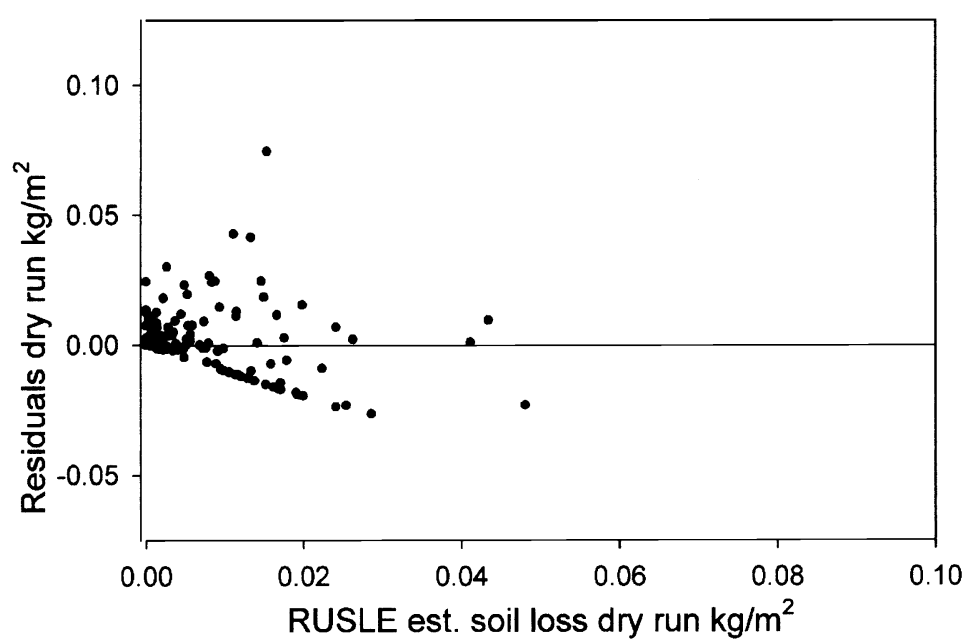

(b)

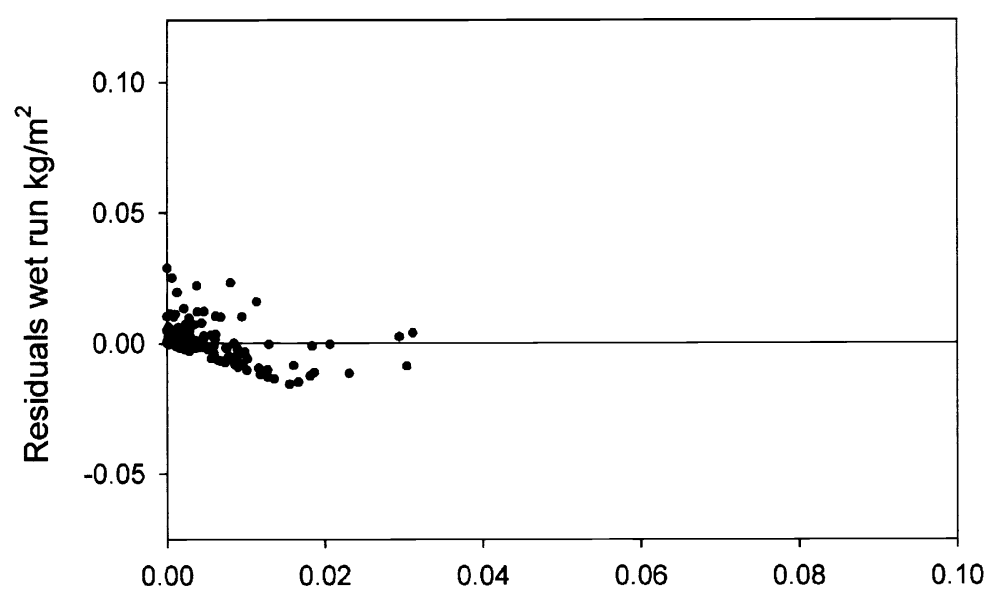

RUSLE est. soil loss wet run $\mathrm{kg} / \mathrm{m}^{2}$

(c)

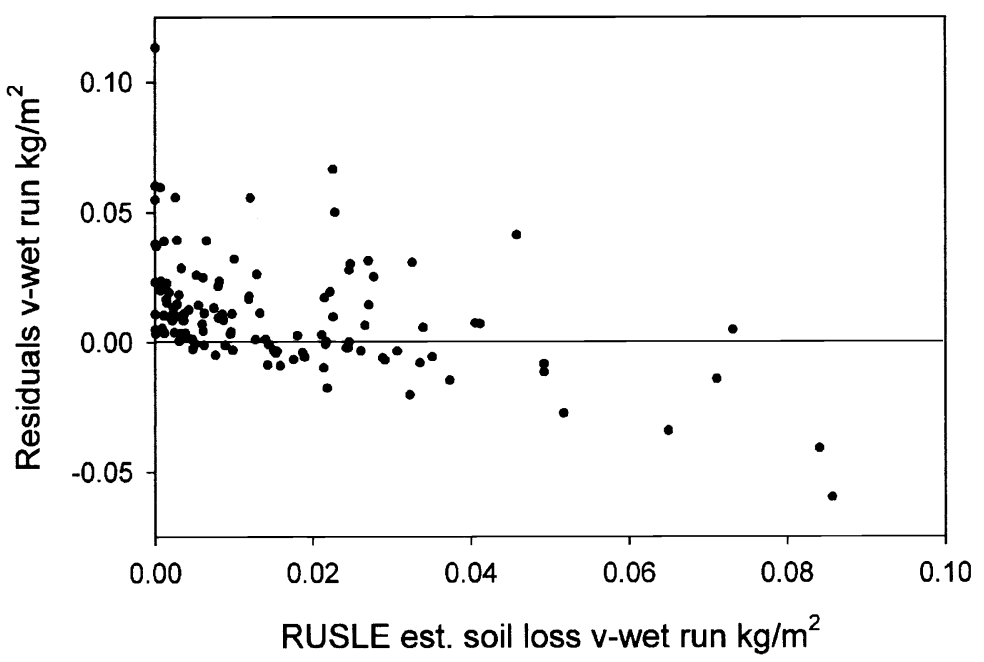

Fig. 4a,b,c. RUSLE predicted soil loss for the dry, wet, and very-wet rainfall simulation treatments plotted against residual values (measured-predicted soil loss). able that overcomes the limitations of USLE and RUSLE 1.06 and is more plant species sensitive, rather than the only option being, identifying the site on a vegetation type basis. Such a tool should include outputs about the entire water budget or for selected parameters, individual storms, long-term climate (monthly-yearly), rare climatic events, and hydrologic responses to management alternatives. Meanwhile, several U.S. land management and resource agencies have begun training and use the Rangeland Health Model to qualitatively assess 3 attributes: hydrologic function, soil surface stability, and biotic integrity. Through proper training and use of the Rangeland Health tool, the 3 attributes can help identify change in rangeland ecosystems. This tool will most likely be used until an ecological based quantitative hydrologic and erosion model is available.

\section{Literature Cited}

Benkobi, L., M.J. Trlica, and J.L. Smith. 1994. Evaluation of a refined surface cover subfactor for use in RUSLE. J. Range Manage. 47:74-78.

Beven, K. 1987. Towards a new paradigm in hydrology. Int. Assoc. of Sci. Hydro. Pub. 164:393-403.

Blackburn, W.H. 1980. Universal soil loss equation and rangelands. p.164-175. In: Proc. of Symp. on Watershed Manage. 80, ASCE, Boise, Ida.

Blackburn, W.H. and C.M. Skau. 1974. Infiltration rates and sediment production of selected plant communities and soils of Nevada. J. Range Manage. 27:476-480.

Blackburn, W.H., F.B. Pierson, and M.S. Seyfried. 1990. Spatial and temporal influence of soil frost on infiltration and erosion of sagebrush rangelands. Water Resour. Bull. 26:991-997.

Bonta, J.V. 1998. Modified drop-box weir for monitoring flows from erosion plots and small watersheds. Trans. of the ASAE 41:565-573.

Brown, L.C. and G.R. Foster. 1987. Storm erosivity using idealized intensity distributions. Transactions of the ASAE 30:379-386.

Buckhouse, J.C. and J.L. Mattison. 1980. Potential soil erosion of selected habitat types in the high desert region of central Oregon. J. Range Manage. 33:282-285.

Dee, F.F., T.W. Box, and E. Robertson. 1966. Influence of grass vegetation on water intake of Pullman silty clay loam. J. Range Manage.19:77-79.

De Soyza, A.G., W.G. Whitford, S.J. Turner, J.W. Van Zee, and A.R. Johnson. 2000a. Assessing and monitoring the health of western rangeland watersheds. Environ. Monitoring and Assess. 64:153-166. 
De Soyza, A.G., J.W. Van Zee, W.G. Whitford, A. Neale, N. Tallent-Hallsel, J.E. Herrick, and K.M Havstad. 2000b. Indicators of Great Basin rangeland health. J. of Arid Environ. 45:289-304.

Flannagan, D.C. and S.J. Livingston. 1995. USDA-Water Erosion Prediction Project (WEPP) User Summary, NSERL Rep. No. 11, USDA-ARS-Natl. Soil Erosion Res. Lab., W. Lafayette, Ind.

Foster, G.R. and L.J. Lane (compilers). 1987. User Requirements. USDA-Water Erosion Prediction Project. NSERL Report \#1, USDA-ARS National Soil Erosion Research Laboratory, West Lafayette, Ind.

Gamougoun, N.D., R.P. Smith, M.K. Wood, and R.D. Pieper. 1984. Soil, vegetation, and hydrologic responses to grazing management at Fort Stanton, New Mexico. J. Range Manage. 37:538-541.

Gauch, H.G. 1982. Multivariate analysis in community ecology. Cambridge Univ. Press., Cambridge, England.

Guiterrez-Castillo, J. 1994. Infiltration, sediment, and erosion under grass and shrub cover in the Southern High Plains. Ph.D. Diss. Texas Tech Univ., Lubbock, Tex.

Gifford, G.F. 1985. Cover allocation in rangeland watershed management (a review), p. 23-31. In: B. Jones and T. Ward (eds.). Watershed management in the eighties: Proc. of a Symp., ASAE, April 30-May 1, 1985. Denver, Colo.

Hawkins, R.H. 1985. Hydrology and the Universal Soil Loss Equation: Application to rangelands. BLM-YA-PT-85-001-4340. BLM, Denver, Colo.

Hanson, C.L., J.R. Wight, C.W. Slaughter, F.B. Pierson, and K. Spaeth. 1999. Simulation models and management of rangeland ecosystems: past, present, and future. Rangelands 21:32-38.

Hart, G.E. 1984. Erosion from simulated rainfall on mountain rangeland in Utah. J. of Soil Water Conserv. 39:330-334.

Heede, B.H. 1979. Deteriorated watersheds can be restored: A case study. Environ. Manage. 3:271-281.

Johnson, C.W. and N. E. Gordon. 1988. Runoff and erosion from rainfall simulator plots on sagebrush rangeland. Trans. Amer. Soc. of Agr. Eng. 31:421-427.

Johnson, C.W., M.R. Savabi, and S.A. Loomis. 1984. Rangeland erosion measurements for the USLE. Trans. Amer. Soc. of Agr. Eng. 5:1313-1320.

Mazurak, A.P. and E.C. Conrad. 1959. Rates of water entry in three great soil groups after seven years in grasses and small grains. Agron. J. 51:264-267.

McGinty, W.A., F.E. Smeins, and L.B. Merrill. 1979. Influence of soil, vegetation, and grazing management on infiltration rate and sediment production of Edwards plateau rangeland. J. Range Manage. 32:33-37.

Nash, J.E., and J.E. Sutcliffe. 1970. River flow forecasting through conceptual models. Part 1-A discussion of principles. J. Hydro. 10:282-290.
National Resource Council. 1994. Rangeland health. New methods to classify, inventory, and monitor rangelands. Nat. Acad. Press. Washington, D.C.

Nearing, M.A. 1998. Why soil erosion models over-predict small soil losses and under-predict large soil losses. Catena 32:15-22.

Pellant, M., P. L. Shaver, D.A. Pyke, and J.E. Herrick. 2000. Interpreting Indicator of Rangeland Health version 3. Technical Reference 1734-6. USDI-BLM, Denver, Colo.

Pierson, F.B., D.H. Carlson, K.E. Spaeth, and M.E. Weltz. 2002. Hydrologic response of diverse western rangelands. J. Range. Manage. 55:558-570

Pierson, F.B., P.R. Robichaud, and K.E. Spaeth. 2001. Spatial and temporal effects of wildfire on the hydrology of a steep rangeland watershed. Hydrol. Process. 15:2905-2916.

Renard, K.G., G.R. Foster, G.A. Weesies, D.K. McCool, and D.C. Yoder. 1997. Predicting soil erosion by water: a guide to conservation planning with the revised universal soil loss equation (RUSLE). USDA., Agr. Handb. No. 703.

Renard, K.G. and J.R. Simanton. 1990. Application of RUSLE to rangelands. p. 164-173. In: Watershed Planning and Analysis in Action Symposium. Proc. of IR Conference Watershed Mgt/IR Div/ASCE, Durango, Colo.

Renard, K.G., G.R. Foster, G.A. Weesies, and J.P. Porter. 1991. RUSLE: Revised universal soil loss equation. J. Soil Water Conserv. 46:30-33.

Renard, K.G. and G.R. Foster. 1985. Managing rangeland soil resources: the universal soil loss equation. Rangelands 7:118-122.

Risse, L.M., M.A. Nearing, A.D. Nicks, and J.M. Laflen. 1993. Error assessment in the universal soil loss equation. Soil Sci. Amer. J. 57:825-833.

SAS Institute Inc. 1999. SAS/STAT users guide, Version 6.12. Cary, N.C.

Satterlund, D.R. 1972. Wildland watershed management. Ronald Press Co., New York, N.Y.

Simanton, J.R., H.B. Osborn, and K.G. Renard. 1977. Effects of brush to grass conversion on the hydrology and erosion of a semiarid southwestern rangeland watershed. p. 249-256. In: Proc. of the 1977 meetings of the Arizona section-American Water Resources Assoc., and the hydrology section of the Arizona academy of Science. April 15-16, 1977. Las Vegas, Nev.

Simanton, J.R., H.B. Osborn, and K.G. Renard. 1980. Application of the USLE to southwestern rangelands. p. 213-220. In: Proc. of the 1980 meetings of the Arizona section-American Water Resources Assn., and the hydrology section-Arizona-Nevada Academy of Science. April 11-12, 1980. Las Vegas, Nev.

Simanton, J.R., M.A. Weltz, and H.D. Larsen. 1991. Rangeland experiments to parameterize the water erosion prediction project model: vegetation canopy cover effects. J. Range Manage. 44:276-282.
Simanton, J.R., T.L. West, M.A. Weltz, and W.G. Wingate. 1987. Rangeland experiments for water erosion prediction project. Amer. Soc. of Agr. Eng. Internat. Winter Meetings. Paper No. 87-2545. December 15-18. Chicago, Ill.

Spaeth, K.E. 1990. Hydrologic and ecological assessments of a discrete range site on the southern High Plains. Ph.D. Diss. Texas Tech Univ., Lubbock, Tex.

Spaeth, K.E., F.B. Pierson, and M.A. Weltz. 2001. Grazingland Hydrology: Chapter 7. In: USDA-National Resources Conservation Service National Range and Pasture Handbook. Nat. Res. Cons. Serv., Grazing lands Institute, Ft. Worth, Tex.

Spaeth, K.E., F.B. Pierson, M.A. Weltz, and J.B. Awang. 1996a. Gradient analysis of infiltration and environmental variables related to rangeland vegetation. Trans. of the ASAE 39: 67-77.

Spaeth, K.E., T.L. Thurow, W.H. Blackburn,and F.B. Pierson. 1996b. Ecological dynamics and management effects on rangeland hydrologic processes. $p$. 25-51. In: Spaeth, K.E., F.B. Pierson, M.A. Weltz, and G. Hendricks. 1996 (eds.). Rangeland hydrology issues: perspectives for the $21^{\text {st }}$ century. Soc. for Range Manage., Denver, Colo.

Swanson, N.P. 1965. Rotating-boom rainfall simulator. Trans. ASAE. 8:71-72.

Thomas, G.W. and J.A.Young.1954. Relation of soils, rainfall, and grazing management to vegetation, western Edwards Plateau of Texas, Texas Agr. Exp. Sta. Bull.786.

Thurow, T.L. 1991. Hydrology and erosion. p. 141-159. In: R.K. Heitschmidt and J.W. Stuth (eds.). Grazing management: An Ecological Perspective. Timber Press, Inc. Portland, Ore.

USDA. 1998. Frank, C.D., F.B. Pierson, A.G. Mendenhall, K.E. Spaeth, and M.A. Weltz (eds.). Interagency rangeland water erosion project report and state data summaries. USDA-ARS/NRCS, NWRC 98-1. Boise, Ida.

USDA-National Resources Conservation Service. 1997. National range and pasture handbook. Nat. Resources Conser. Serv., Grazing lands Inst., Ft. Worth, Tex.

USDA-Soil Conservation Service. 1992. Soil Survey Laboratory Methods Manual. Soil Survey Investigations Report No. 42, Version 2.0, August 1992. Soil Cons. Serv. Nat. Soil Surv. Center, Lincoln, Nebr.

Warren, S.D., W.H. Blackburn, and C.A. Taylor, Jr. 1986. Effects of season and stage of rotation cycle on hydrologic condition of rangeland under intensive rotation grazing. $\mathrm{J}$. Range Manage. 39:486-491.

Weltz, M.A., M.R. Kidwell, and H.D. Fox. 1998. Influence of abiotic and biotic factors in measuring and modeling soil erosion on rangelands: State of knowledge. J. Range Manage. 51:482-495.

Weltz, M.A., M.R. Kidwell, M. Hernandez, and R.L. Jemison. 1997. Vegetation and soil surface cover adjustments to interrill soil erodibility on rangeland. p. 977-982. In: S.S.Y. Wang, E.J. Langendoen, and F.D. 
Shields, Jr. (eds.). Proc. of the conference on management of landscapes disturbed by channel incision, Oxford, Mass.

Wight, J.R., and F.H. Siddoway. 1982. Determinants of soil loss tolerance for rangelands. p. 67-74. In: Schmidt, B.L., R.R. Allmaras, J.V. Mannering, and R.I. Papendick (eds.). Determinants of Soil Loss Tolerance ASA Spec. Publ. Number 45. Amer. Soc. of Agron. and Soil Sci. Soc. Amer., Madison, Wisc.

Wilcox, B.P., C.L. Hanson, J.R. Wight, and W.H. Blackburn. 1989. Sagebrush rangeland hydrology and evaluation of the SPUR hydrology model. Water Res. Bull. 25:653-666.
Wischmeier, W.H. 1975. Estimating the soil loss equations cover and management factor for undisturbed areas. p. 118-124. In: Present and prospective technology for predicting sediment yields and sources. Proc. of the Sediment-Yield Workshop, USDA Sedimentation Laboratory, Oxford, Mississippi, Nov. 2830,1972. ARS-S-40.

Wischmeier, W.H. 1976. Use and misuse of the universal soil loss equation. J. Soil and Water Conserv. 31:5-9.

Wischmeier, W.H. and D.D. Smith. 1965. Predicting rainfall erosion losses from cropland east of the Rocky Mountains. USDA Handb. 282, U.S. Gov. Print. Off., Washington, D.C.
Wischmeier, W.H. and D.D. Smith. 1978. Predicting rainfall erosion losses, a guide to conservation planning. USDA Handb.. 537, U.S. Gov. Print. Off., Washington, D.C.

Wood, M.K. and W.H. Blackburn. 1981. Sediment production as influenced by livestock grazing in the Texas Rolling Plains. J. Range Manage. 34:228-231.

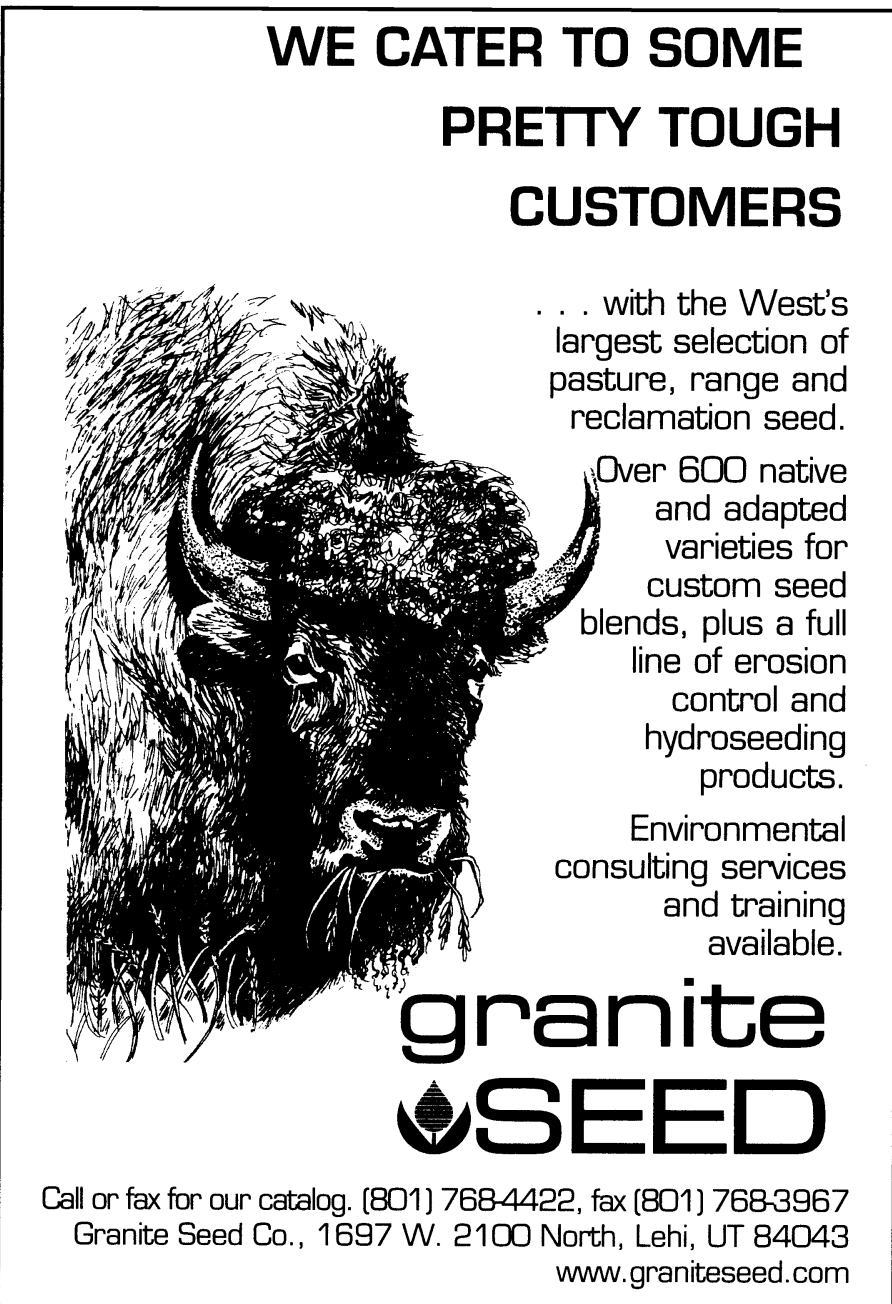




\title{
Germination of seeds of robust needlegrass
}

\author{
JAMES A. YOUNG*, CHARLIE D. CLEMENTS, AND T. A. JONES
}

Authors are Range Scientists, USDA, Agricultural Research Service, 920 Valley Road, Reno, Nevada 89512 and Research Geneticist, USDA, Agricultural Research Service, Forage and Range Research Laboratory, Utah State University, Logan, Utah 84322-6300.

*E-mail address corresponding author jayoung@scs.unr.edu

\begin{abstract}
Robust needlegrass (Achnatherum robustum [Vasey] Barkw.) is a native perennial that has great promise for use in erosion control, restoration, and ornamental plantings. Seed dormancy can be a problem in developing new native grass cultivars, especially in species of Achnatherum and related genera. Germination response to a wide range of constant and alternating incubation temperatures is also a key parameter in interpreting seedbed ecology of potential planting material. Our purpose was to investigate the germination of robust needlegrass at 55 constant or alternating incubation temperatures from 0 through $40^{\circ} \mathrm{C}$. Seeds of robust needlegrass germinate over a wide range of incubation temperatures with maximum observed germination over $75 \%$. In terms of restoration ecology, this means that in contrast to many related grass species, severe seed dormancy is not a limiting factor in seeding technology. Optimum germination occurred with 15 to $20^{\circ} \mathrm{C}$ warm periods alternating with 0 to $20^{\circ} \mathrm{C}$ cool periods. The only constant temperature to produce optimum germination was $20^{\circ} \mathrm{C}$. The highest germination occurred at what we consider moderate seedbed temperatures, but some germination occurred at 76 to $89 \%$ of the temperature regimes tested.
\end{abstract}

Key Words: seedbed temperatures, optimum germination temperatures, seed ecology

Robust needlegrass (Achnatherum robustum [Vasey] Barkw. is native to the central Rocky Mountains from Wyoming south to Colorado, Arizona, New Mexico and extending into west Texas and adjacent Mexico (Hitchcock 1935, Hickman 1993, Jones et al. 2000). As the name implies, it is a large grass with culms reaching 1 to $1.5 \mathrm{~m}$ in height. It is not a coarse grass, the leaves are fine and the narrow panicles are quite attractive in appearance. Robust needlegrass has not been developed as a forage or restoration species because of its reputation for inducing narcosis in horses and general avoidance by grazing animals (Bailey 1903). Recent research indicates the narcosis and avoidance by herbivores are a function of an endophyte infection (Jones et al. 2000). Endophyte free lines of robust needlegrass have been developed.

Robust needlegrass has several characteristics that make it a desirable native grass to develop for planting on wildland sites. This species is a very productive grass from which large amounts of biomass can be harvested (Jones et al. 2000). The production tends to occur later in the growing season after the herbage of cool season grasses has matured. Trials located in the Great Basin

\section{Resumen}

Robust needlegrass (Achnatherum robustum [Vasey] Barkw.) es una especie perenne nativa que tiene un gran potencial para usarla en el control de erosión y siembras de restauración y ornamentales. La dormancia de la semilla puede ser un problema en desarrollar nuevos cultivares de zacates nativos, especialmente de especies del genero Achnatherum y generos relacionados. La respuesta de la germinación a un amplio rango de temperaturas de incubación constantes y alterante es también un parámetro clave en interpretar la ecología de la cama de siembra de material potencial para plantar. Nuestro propósito fue investigar la germinación de "Robust needlegrass" a 55 temperaturas de incubación constantes y alternantes variando de 0 a $40^{\circ} \mathrm{C}$. Las semillas de "Robust needlegrass germinaron en un amplio rango de temperaturas de incubación, el máximo porcentaje de germinación observado fue arriba de $75 \%$. En términos de ecología de restauración, esto significa que en contraste a muchas especies de zacates relacionadas, una dormancia de semilla severa no es un factor limitante en la tecnología se siembra. La geminación óptima ocurrió con periodos calientes de $\mathbf{1 5}$ a $20^{\circ} \mathrm{C}$ alternando con periodos fríos de 0 a $20^{\circ} \mathrm{C}$. La única temperatura constante en producir una germinación óptima fue la de $20^{\circ}$ C. La mayor germinación ocurrió en lo que nosotros consideramos una temperatura moderada de la cama de siembra, pero algo de germinación ocurrió en 76 a $89 \%$ de los regímenes de temperatura evaluados.

have indicated that robust needlegrass plants are at least as tolerant to salt affected soils as tall wheatgrass (Elytriga elongata [Host.] Nevski) (unpublished research USDA, ARS, Reno, Nev.). Robust needlegrass is an attractive grass that enhances the visual aspect of landscapes where it is adapted.

A necessary step in getting a new native plant species into the seed trade is to understand the germination characteristics. This is necessary because of: 1) the need to understand germination ecology to propagate the species, and 2) for the legal requirement that the Association of Official Seed Analysts must have an approved standard procedure for germination testing before meaningful percentage germination figures can appear on seed lot tags. Germination in relation to incubation temperatures is a first step in this process.

Our purpose was to develop germination temperature profiles for seeds (caryopses) of robust needlegrass using a wide range of constant and alternating incubation temperatures.

Manuscript accepted 4 Aug. 02. 
Table 1. Germination parameters calculated from quadratic response surfaces (Young and Evans 1982).

\begin{tabular}{|c|c|c|}
\hline Calculated parameters & Derivation of parameter & Purpose \\
\hline \multicolumn{3}{|l|}{ Calculated within profile: } \\
\hline Mean germination & Sum divided by 55 & Gross comparison of profiles \\
\hline Percentage of regimes with germination & Number with germination divided by 55 & Indication of breath of germination response \\
\hline Percentage of regimes with optima & $\begin{array}{l}\text { Number of regimes with germination not } \\
\text { less than the maximum observed minus } \\
\text { one half the confidence interval divided } \\
\text { by } 55\end{array}$ & $\begin{array}{l}\text { Provides indication of the breath of temperatures } \\
\text { that support optimum germination }\end{array}$ \\
\hline Mean of optima & $\begin{array}{l}\text { Sum of optima divided by number of } \\
\text { regimes with optima }\end{array}$ & $\begin{array}{l}\text { Provides a measure of potential germination at } \\
\text { at most desirable temperatures }\end{array}$ \\
\hline Maximum germinatio & Highest observed germination & Indication of potential viability \\
\hline \multicolumn{3}{|l|}{$\underline{\text { Calculated among germination profiles }}$} \\
\hline Frequency of optima & $\begin{array}{l}\text { Times a given temperature supports } \\
\text { optimum germination divided by the } \\
\text { total number of test }\end{array}$ & $\begin{array}{l}\text { Provides an estimate of optimum temperatures } \\
\text { for germination with precision }\end{array}$ \\
\hline
\end{tabular}

\section{Materials and Methods}

Seeds of robust needlegrass were harvested from seed increase fields located at Richland, Utah in 1998 and 1999. Seed was also harvested in 1999 from a stand growing on a saline/alkaline soil near Reno, Nev. (Lat. 39 $32^{\prime}$ Long. 1190 48'). These plants originated from seed harvested at Richland, Utah in 1998 (Lat. 41 ${ }^{\circ}$ 54' Long. $\left.111^{\circ} 50^{\prime}\right)$. This seed was collected from plants that flowered their seedling year.

In all experiments 4 replications of 25 seeds each were used in a randomized block design. Seeds were placed on top of non-toxic commercial germination paper in closed Petri dishes and kept wet with tap water. Germination trials were conducted in the dark with only incidental fluorescent light received during initial wetting and germination counts. Except for the most extremely light sensitive seeds this exposure would not be sufficient to over come dormancy induced by a light quality requirement. Robust needlegrass seeds are adapted for self burial, suggest- ing germination occurs in the dark. Seeds were considered germinated when the radical emerged $5 \mathrm{~mm}$. Germination counts were made after 1, 2, and 4 weeks incubation. Constant incubation temperatures were 0,2 and $5^{\circ} \mathrm{C}$ and at 5 degree increments through $40^{\circ} \mathrm{C}$. In addition, alternating regimes included 16 hours at each constant temperature, plus 8 hours at each possible higher temperature per 24 hours. For example, $35^{\circ} \mathrm{C}$ alternated with $40^{\circ} \mathrm{C}$ only, while $0 \mathrm{C}$ alternated with $2,5,10,15,20$, $25,30,35$, and $40^{\circ} \mathrm{C}$. This made a total of 55 constant and alternating temperature regimes (Young and Evans 1982).

The germination response of robust needlegrass seeds was compared using the seedbed temperature definitions (Young and Evans 1982):

a. Very cold: $0 / 0$ (constant $\left.0^{\circ} \mathrm{C}\right), 0 / 2\left(0^{\circ}\right.$ $\mathrm{C}$ for 16 hours and $2^{\circ} \mathrm{C}$ for 8 hours in each 24 hours period), $0 / 5$ and $2 / 2^{\circ} \mathrm{C}$.

b. Cold: $0 / 10,0 / 15,2 / 5,2 / 10,2 / 15,5 / 5$, and $5 / 10^{\circ} \mathrm{C}$.

c. Cold fluctuating: $0 / 20$ through $0 / 40^{\circ} \mathrm{C}$ and $2 / 20$ through $2 / 40^{\circ} \mathrm{C}$. d. Fluctuating: $5 / 30$ through $5 / 40^{\circ} \mathrm{C}$, $10 / 35,10 / 40$, and $15 / 40^{\circ} \mathrm{C}$.

e. Moderate: $5 / 15$ through $5 / 25,10 / 10$ through $10 / 30^{\circ} \mathrm{C}, 15 / 15$ through $15 / 35^{\circ} \mathrm{C}, 20 / 20$ through $30 / 35^{\circ} \mathrm{C}$, and $25 / 35^{\circ} \mathrm{C}$.

f. Warm: $20 / 40,25 / 35$, and $25 / 40^{\circ} \mathrm{C}$, $30 / 30$ through $30 / 40^{\circ} \mathrm{C}, 35 / 35,35 / 40$, and $40 / 40^{\circ} \mathrm{C}$.

These categories of seedbed temperatures reflect germination environments of field seedbeds based on several years of monitoring in the Great Basin (Evans et al. 1970; Evans and Young 1970, 1972).

Data from each base temperature and its alternating temperature regimes were used to generate a quadratic response surface with estimated means and confidence intervals at the $1 \%$ level of probability (Young et al. 1980, Evans et al. 1982). This statistical procedure was designed for analysis and separation of means when dealing with a continuous variable, in this case incubation temperature. The response surfaces provide continuous statistically precise estimates of germination within

Table 2. Quadratic response surface with estimated percentage germination and confidence interval $(P>0.01)$ for seeds of robust needlegrass incubated at 55 constant or alternating temperatures. Seed produced at Richland, Utah in 1998 . $^{1}$

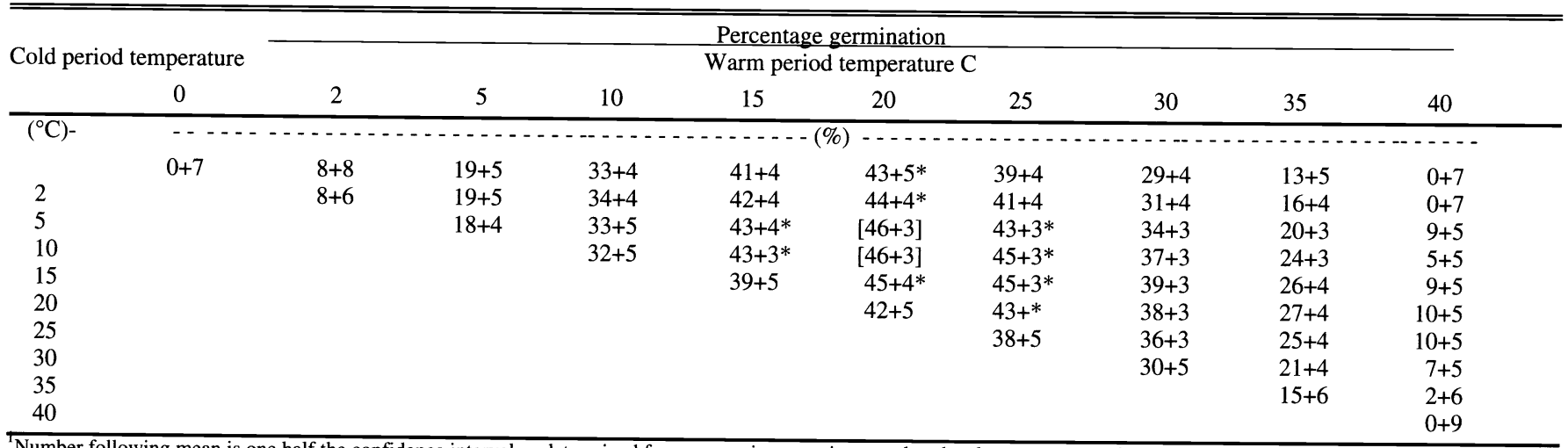

Number following mean is one half the confidence interval as determined from regression equations used to develop response surface (Palmquist et al. 1987). The maximum calculated germination is enclosed by brackets. * indicates means not lower than the maximum germination minus one half of its confidence interval, our definition of optimum germination. 
Table 3. Quadratic response surface with estimated percentage germination and confidence interval $(P>0.01)$ for seeds of robust needlegrass incubated at 55 constant or alternating temperatures. Seed produced at Richland, Utah in $1999 .{ }^{1}$

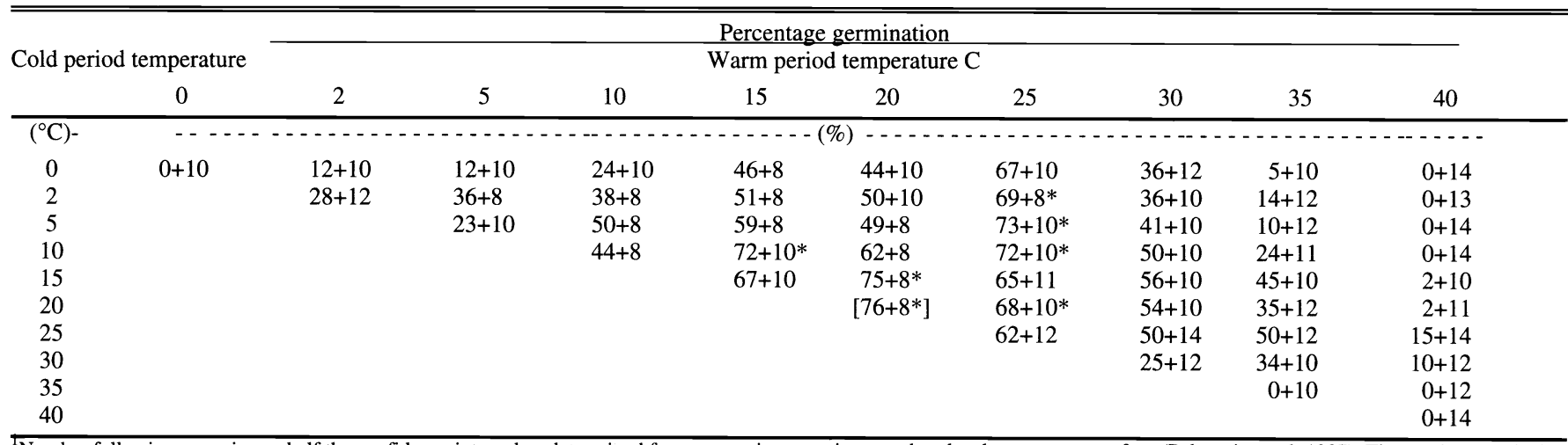

Number following mean is one half the confidence interval as determined from regression equations used to develop response surface (Palmquist et al. 1987). The maximum calculated germination is enclosed by brackets. * indicates means not lower than the maximum germination minus one half of its confidence interval, our definition of optimum germination.

the range of incubation temperatures tested. A number of germination parameters were calculated from the quadratic response surfaces (Table 1) (Young and Evans 1982).

\section{Results and Discussion}

Several related grasses in the needlegrass tribe are notorious for having highly dormant seeds. For some species, such as Indian ricegrass (Achnatherum hymenoides [Roemer \& Schultes] Barkworth), the dormancy may be more of a factor in the laboratory than a hindrance to seedling establishment in the field (Blank and Young 1992, Young et al. 1994). Needle and threadgrass (Hesperostipa comata [Trin. \& Rupr.] Barkworth) obviously recruits seedlings spontaneously in the field, but the seeds are very dormant in the laboratory or most artificial field plantings. Both Columbia needlegrass (Achnatherum lem- momii [Vassey] Barkworth) and desert needlegrass (A. speciosum [Trin. \& Rupr.] Barkworth) produce seeds with limited or no dormancy (Young and Evans 1980, Young et al. 1990). Fortunately, the seeds of robust needlegrass germinate with little evidence of dormancy.

The seeds of robust needlegrass will germinate at a wide range of constant and alternating temperatures (Tables 2, 3, and 4). For seeds harvested from the seed increase fields at Richland, Utah, there were slight differences in germination between years of production. The seeds produced at Reno, Nev. were unique in that they were collected from a stand seeded the previous fall with seeds from the 1998 Richland, Utah increase fields. These Nevada seedlings were growing without supplemental irrigation on a salt affected soil at less that 150 mm of annual precipitation.

For the entire 55 temperature regime profile, the 2 accessions of Utah seeds were higher in germination than the
Nevada seed (Table 5). Between 76 and $89 \%$ of the temperature regimes tested supported some germination. This is an important parameter for a native species being planted under wildland seedbed conditions. Soil moisture and temperature conditions that support optimum germination may often be out of phase (either too cold or too warm). When moisture is available, the potential for even limited germination at non-optimum temperatures may be critical.

The maximum germination and mean of the optima germination was down for the seed produced in Utah in 1998 (Table 5). Plants grown from this seed produced seed (Reno, Nev. 1999) with much higher maximum germination and a higher mean of optima germination. For a native grass selection, maximum germination above $75 \%$ is a very reasonable amount, based on our 40 years testing the germination of seeds of wildland species. This level of gemination indicates a moderate to good

Table 4. Quadratic response surface with estimated percentage germination and confidence interval $(P>0.01)$ for seeds of robust needlegrass incubated at 55 constant or alternating temperatures. Seeds collected from first year stand grown at Reno, Nevada from seed produced at Richland, Utah in $1998 .{ }^{1}$

\begin{tabular}{|c|c|c|c|c|c|c|c|c|c|c|}
\hline \multirow{2}{*}{\multicolumn{2}{|c|}{ Cold period temperature }} & \multicolumn{8}{|c|}{ Percentage germination } & \multirow[b]{3}{*}{40} \\
\hline & & \multicolumn{8}{|c|}{ Warm period temperature $\mathrm{C}$} & \\
\hline & 0 & 2 & 5 & 10 & 15 & 20 & 25 & 30 & 35 & \\
\hline$\left({ }^{\circ} \mathrm{C}\right)-$ & $\cdots$ & $\cdots$ & - & $-\cdots$ & $\ldots$ & )$-\ldots$ & $\cdots$ & $-\cdots$ & $\cdots$ & $\cdots$ \\
\hline 0 & $0+10$ & $12+10$ & $12+10$ & $24+10$ & $46+8$ & $44+10$ & $67+10$ & $36+12$ & $5+10$ & $0+14$ \\
\hline 0 & $0+8$ & $0+7$ & $0+7$ & $5+4$ & $14+3$ & $25+3$ & $30+6$ & $15+9$ & $6+4$ & $0+7$ \\
\hline 2 & & $0+6$ & $2+7$ & $8+5$ & $12+7$ & $25+4$ & $32+7$ & $15+7$ & $7+7$ & $0+6$ \\
\hline 5 & & & $3+3$ & $10+8$ & $15+8$ & $28+8$ & $35+8$ & $17+8$ & $7+6$ & $0+4$ \\
\hline 10 & & & & $15+6$ & $25+6$ & $32+6$ & $45+4$ & $18+4$ & $8+6$ & $0+6$ \\
\hline 15 & & & & & $40+7$ & {$[78+10]$} & $68+9 *$ & $25+8$ & $18+6$ & $2+2$ \\
\hline 20 & & & & & & $70+11^{*}$ & $66+9$ & $32+9$ & $12+9$ & $0+4$ \\
\hline 25 & & & & & & & $60+9$ & $30+8$ & $8+9$ & $0+6$ \\
\hline 30 & & & & & & & & $3+4$ & $2+5$ & $0+9$ \\
\hline 35 & & & & & & & & & $0+8$ & $0+10$ \\
\hline 40 & & & & & 0 & & & & & $0+10$ \\
\hline
\end{tabular}

${ }^{1}$ Number following mean is one half the confidence interval as determined from regression equations used to develop response surface (Palmquist et al. 1987). The maximum calculated germination is enclosed by brackets. * indicates means not lower than the maximum germination minus one half of its confidence interval, our definition of optimum germination. 
Table 5. Comparison of temperature germination profiles for robust needlegrass seeds. ${ }^{1}$

\begin{tabular}{|c|c|c|c|}
\hline \multirow{2}{*}{$\begin{array}{l}\text { Germination } \\
\text { parameter }\end{array}$} & \multicolumn{3}{|c|}{ Seed source } \\
\hline & Richland, Utah 1998 & Richland, Utah 1999 & Reno, Nevada \\
\hline $\begin{array}{l}\text { Categories of seedbed } \\
\text { temperature }\end{array}$ & ( & - & $\cdots \cdots$ \\
\hline Very cold & 9 & 13 & 1 \\
\hline Cold & 35 & $52 \mathrm{a}$ & $10 \mathrm{~b}$ \\
\hline Cold fluctuating & 26 & 32 & 16 \\
\hline Fluctuating & 13 & 7 & 4 \\
\hline Warmer & 12 & 15 & 2 \\
\hline Moderate & 38 & 57 & 39 \\
\hline Profile mean & $22 \mathrm{a}$ & $29 a$ & $12 \mathrm{~b}$ \\
\hline $\begin{array}{l}\text { Temperature regimes with } \\
\text { some germination }\end{array}$ & $89 a$ & $85 \mathrm{a}$ & $76 b$ \\
\hline Maximum germination & $46 \mathrm{~b}$ & $76 \mathrm{a}$ & $78 \mathrm{a}$ \\
\hline Mean of optima & $44 \mathrm{~b}$ & $72 \mathrm{a}$ & $72 \mathrm{a}$ \\
\hline $\begin{array}{l}\text { Temperature regimes with } \\
\text { optimum germination }\end{array}$ & 18 & 11 & 6 \\
\hline
\end{tabular}

${ }^{\mathrm{T}}$ Means within rows followed by the same letter are not significantly different at the 0.05 level of probability as determined by Duncan' Multiple Range test. No letters indicates no significant differences.

level of viability. Perhaps, viability is higher and germination can be further enhanced, but it not so low as to inhibit commercial seed production and marketing.

At very cold categories of seedbed temperatures there was very limited germination of robust needlegrass seeds (Table 5). These temperatures would correspond to seedbeds that froze at night and slightly thawed during the day. Germination increased at cold seedbed temperatures. Robust needlegrass seeds are not highly adapted to germination at cold fluctuating or fluctuating temperature regimes. This is important because it indicates it is not obligatory to plant the caryopses very shallow in seedbeds where such temperature fluctuations can occur. Robust needlegrass seeds are most adapted to germination at moderate seedbed temperatures.

Only one incubation temperature, $15 / 20$ $\mathrm{C}\left(15^{\circ} \mathrm{C}\right.$ for 16 hours and $20^{\circ} \mathrm{C}$ for 8 hours in each 24 hour period) always supported optimum germination (Table 6). Optimum regimes for germination were confined to 15,20 , or $25^{\circ} \mathrm{C}$ warm period temperatures alternating with 5 to $15^{\circ} \mathrm{C}$ cold period temperatures. Only $20^{\circ} \mathrm{C}$ warm period temperatures supported optimum germination when alternating with 0 or $2^{\circ} \mathrm{C}$ cold period temperatures. The only constant incubation temperature that supported optimum germination was $20^{\circ} \mathrm{C}$. If you wish to conduct laboratory test of the germination of seeds of robust needlegrass, the obvious choice for incubation temperature would be $15 / 20^{\circ} \mathrm{C}$. If you do not have incubators that allow for alternating temperature regimes, an constant incubation temperature of $20^{\circ} \mathrm{C}$ should be used. Seeds of robust needlegrass have limited if any dormancy and moderate to good viability as indicated by the maximum germination obtained.

\section{Literature Cited}

Bailey, V. 1903. Sleepy grass and its effect on horses. Sci. 17:576-581.
Blank, R.R. and J.A. Young. 1992. Influence of matric potential and substrate characteristics on germination of Nezpar Indian ricegrass. J. Range Manage. 45:358-362.

Evans, R.A. and J.A. Young. 1970. Plant litter and establishment of alien annual species in rangeland communities. Weed Sci. 18:697-703.

Evans, R.A. and J.A. Young. 1972. Microsite requirements for establishment of alien annual species in rangeland communities. Weed Sci. 20:350-356.

Evans, R.A., D.A. Easi, D.N. Book, and J.A. Young. 1982. Quadratic response surface analysis of seed germination trials. Weed Sci. 30:411-416.

Evans, R.A., H.R. Holbo, R.E. Eckert, Jr., and J.A. Young. 1970. Functional environment of downy brome communities in relation to weed control and revegetation. Weed Sci 18:154-162.

Hickman, J.C.(ed.).1993. The Jepson Manual. Univer. California Press, Berkeley, Calif.

Hitchcock, A S. 1935. Manual of grasses of the United States. Misc. Publ. 200, Washington, D. C.

Jones, T.A., M. H. Ralphs, D.R. Gardner, and N.J. Chatterton. 2000. Cattle prefer endophyte-free robust needlegrass. J. Range Manage. 53:427-431.

Palmquist, D.E., R.A. Evans, and J.A. Young. 1987. Comparative analysis of temperature response surfaces. pp. 97-103 In G.W. Frasier and R. A. Evans (eds.) Seed and Seedbed Ecology of Rangeland Plants. USDA, Agr. Res. Ser., Washington, D. C.

Young, J.A. and R.A. Evans. 1980. Germination of desert needlegrass. J. Seed Tech. 5:40-46.

Young, J.A. and R.A. Evans. 1982. Temperature profiles for germination of cool season grasses. ARR-W-72, USDA, ARS, Oakland, Calif.

Young, J.A., F.L. Emmerich, and B. Patten. 1990. Germination of Columbia needlegrass. J. Seed Tech. 14:225-229.

Young, J.A., R.R. Blank, W.S. Longland, and D.E. Palmquist. 1994. Seeding Indian ricegrass in arid environments in the Great Basin. J. Range Manage. 47:2-7.

Young, J.A., B.L. Kay, H. George, and R.A. Evans. 1980. Germination of three species of Atriplex. Agron. J. 72:705-709.

Table 6. Frequency that temperature regimes supported optimum germination of seeds of robust needlegrass. This provides an estimate of the temperature regimes that most frequently support optimum germination.

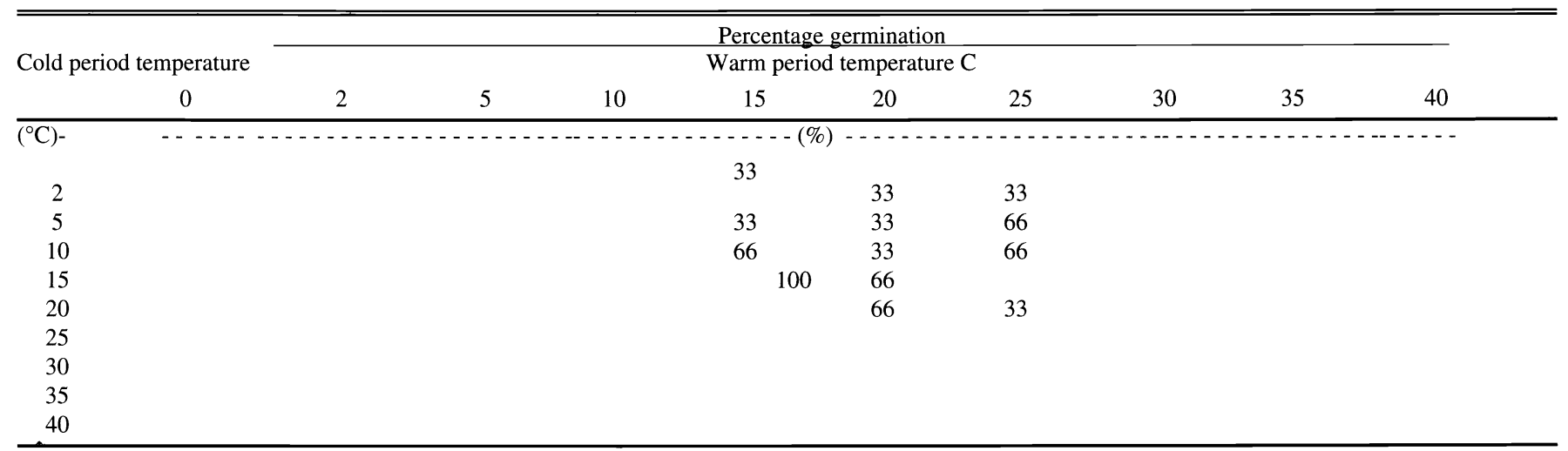




\title{
Technical Note: A technique for conducting small-plot burn treatments
}

\author{
JOHN L. KORFMACHER, JEANNE C. CHAMBERS, ROBIN J. TAUSCH, BRUCE A. ROUNDY, SUSAN E. \\ MEYER, AND STANLEY KITCHEN
}

Authors are, respectively, Ecologist, Research Ecologist, and Project Leader, USDA Forest Service, Rocky Mountain Research Station, Reno Forestry Sciences Laboratory, 920 Valley Rd., Reno, Nev. 89512; Professor, Dept. of Botany and Range Science, Brigham Young University, Provo, Ut. 84602; Ecologist and Botanist, USDA Forest Service, Rocky Mountain Research Station, Shrub Sciences Laboratory, 735 N $500 E$, Provo, Ut. 84606.

\begin{abstract}
An experimental design required burn treatments for $10-\mathrm{m}^{2}$ circular plots. We constructed a fire enclosure for the plots using sheetmetal, electrical conduit, and other commonly available materials. We field tested the enclosure in sagebrush-grass ecosystems in central Nevada and central Utah, and evaluated peak fire temperatures using small metal tags striped with temperature sensitive paint. We obtained average peak surface temperatures of 310,307 , and $381^{\circ} \mathrm{C}$ in bare ground, under grass, and under shrub microsites, respectively, for the Nevada sites and 253,299 , and $337^{\circ} \mathrm{C}$ for the same microsites, respectively, in Utah. Subsurface $\left(2-\mathrm{cm}\right.$ depth) temperatures rarely exceeded $7^{\circ}$ $C$, the lowest temperature detectable by our method. The enclosure contained the fire and did not permit escape of any embers or firebrands. The fire enclosure, burn technique and temperature monitoring method used are inexpensive, easily deployed, and desirable for experiments where larger-scale burns are impractical.
\end{abstract}

Key Words: Fire, Great Basin, sagebrush, burn barrel, temperature, temperature monitoring

The consequences and benefits of wildland fire have recently received greater attention from researchers and land managers, particularly in the western U.S. Effects of large wildland fires or prescribed burns can be examined without the use of experimental equipment at any spatial scale, but experiments at smaller (i.e., microhabitat) spatial scales often require control and monitoring of fire effects and environmental factors. In many of these experiments, it is necessary to restrict fire effects to small study plots, prevent disturbance of nearby control plots, maintain control of the fire, and ensure worker safety. This technical note describes a

We thank Ben Rau, Lorie Haselhorst, Leigh Metcalf, Allison Whittaker, Susan Garvin, and Stephanie Carlson, and Dan Symmes for technical assistance, and Dave Turner for statistical advice. We also thank Laurence Crabtree, Dave Haney, and the Mountain City fire crew of the Humboldt-Toiyabe National Forest; and Dave Davis and the Austin fire crew of the Battle Mountain District, Bureau of Land Management, for support in conducting the burn treatments. We thank Robert Blank and two anonymous reviewers for their help in improving the manuscript.

The use of trade or firm names in this paper is for reader information and does not constitute endorsement by the US Department of Agriculture of any product or service. This work was funded in part by Joint Fire Sciences Program,

Manuscript accepted 13 Jul 02.

\section{Resumen}

Un diseño experimental requirió tratamientos de quema en parcelas circulares de $10 \mathrm{~m}^{2}$. Construimos una exclusión contra fuego para las parcelas utilizando hojas de metal, tubos metálicos para conducción de cables de electricidad (conduit) y otros materiales comúnmente disponibles. Probamos la exclusión en campo en ecosistemas de "Sagebrush-zacate" de la región central de Nevada y Utah y evaluamos las temperaturas pico del fuego usando pequeñas etiquetas de metal marcadas con pintura sensible al calor. En los sitios de Nevada obtuvimos una temperaturas pico promedio de la superficie de 310,307 y $381^{\circ} \mathrm{C}$ en suelo desnudo, bajo el zacate y en los micrositios de los arbustos respectivamente, en tanto en Utah registramos 253,299 y $337^{\circ} \mathrm{C}$ respectivamente para los mismos micrositios. Las temperaturas subsuperficiales $(2 \mathrm{~cm}$ de profundidad) raramente excedieron $\operatorname{los} 79^{\circ} \mathrm{C}$, esta fue la temperatura mas baja detectable por el nuestro método. La exclusión contuvo el fuego y no permitió el escape de rescoldos ni llamaradas. La exclusión para fuego, la técnica de quemado y el método de monitoreo de temperatura son baratos, fácilmente desplegados y deseables para experimentos donde las quemas a gran escala son imprácticas.

portable device and procedures for conducting small-plot burn treatments, and a convenient and inexpensive method of monitoring peak fire temperatures.

Many studies examine effects on small plots in the context of larger fire events. For example, Perez and Moreno (1998) examined $1 \times 1 \mathrm{~m}$ plots inside a $3 \times 22 \mathrm{~m}$ burn plot. Other studies established small plots in an area being prepared for a large prescribed burn (Cole et al. 1992), or in areas later subjected to wildfire (Kutiel and Inbar 1993). Restricting fire to the limits of a plot also can be effected by arrangement of fuel in piles (e.g., Tanaka et al. 2001).

A number of fire enclosure or burning devices have been developed for various purposes. Wright and Klemmedson (1965) fabricated a combustor out of a 208-liter ("55-gallon") size drum that used shredded paper for fuel, and used the device to burn individual plants. Propane-fired burners are also in use, in sizes up to $107 \mathrm{~cm}$ in diameter (Britton and Wright 1979). However, it is not practical to adapt either of these designs for use on larger (3-5 m diameter) plots.

Knowledge of fire characteristics is important to understanding post-fire vegetation dynamics and soil chemical characteristics and processes (Wright and Bailey 1982, Whelan 1995). Fire 
effects can be evaluated by collecting data on the intensity and duration of the fire or by observing fire parameters such as energy release, flame length, and residence time (Sapsis and Kauffman 1991). Ideally, this information is collected using thermocouples linked to data recorders (e.g., McDaniel et al. 1997) or evaluated using time-temperature curves and fuel loading for a particular fuel type (e.g., Wright et al. 1976). However, limitations imposed by study design, time, or other factors may make these methods impractical. A simpler, more economical method uses temperature-sensitive tablets ("Tempils"), which melt at certain temperatures (Shearer 1975). Temperature-sensitive paint, applied to ceramic tiles or mica plates (Gibson et al. 1990) or to aluminum tags (Cole et al. 1992) permits a large number of sensors for coverage of extensive areas or high sampling density. These methods do not permit a rigorous evaluation of the range of fire effects, but they are useful for examining 2- or 3-dimensional spatial variability of fire intensity (Cole et al. 1992).

\section{Materials and Methods}

Our fire enclosure (Fig. 1) was designed to treat a circular, 3.4-m diameter plot, prevent escape of embers and firebrands, be easily lifted and carried by 3-4 workers, and be transported in a standard-bed pickup truck. All materials used in assembly of the enclosure were purchased at local hardware stores. It was constructed of 16 panels of corrugated sheetmetal, each $122 \times 61 \mathrm{~cm}$, with $1-\mathrm{cm}$ gaps between panels for ventilation. For ease of transport and field portability, the enclosure was constructed in 4 sections of 4 panels each. The panels are joined by $3.8-$ $\mathrm{cm}$ (1.5-inch) hinges. Each section of 4 panels was reinforced by two, 244-cm lengths of $1.9-\mathrm{cm}(0.75$-inch) diameter electrical conduit that were shaped on a plumber's pipe bender. The reinforcements were attached to the panels at $10 \mathrm{~cm}$ from the top and bottom edges with bolts on $30-\mathrm{cm}$ centers. The sections were joined by short lengths of $2.5-\mathrm{cm}$ (1-inch) electrical conduit and straight pins (Fig. 2). To make a screen for the top of the fire enclosure, we assembled a framework from four, $180-\mathrm{cm}$ long angle irons bolted together in the center and reinforced by a $2.5 \times 40 \times 0.5 \mathrm{~cm}$ piece of steel. We attached $0.6-\mathrm{cm}(0.25$-inch $)$ hardware cloth, cut to a circular shape, to this framework. All fasteners used were standard

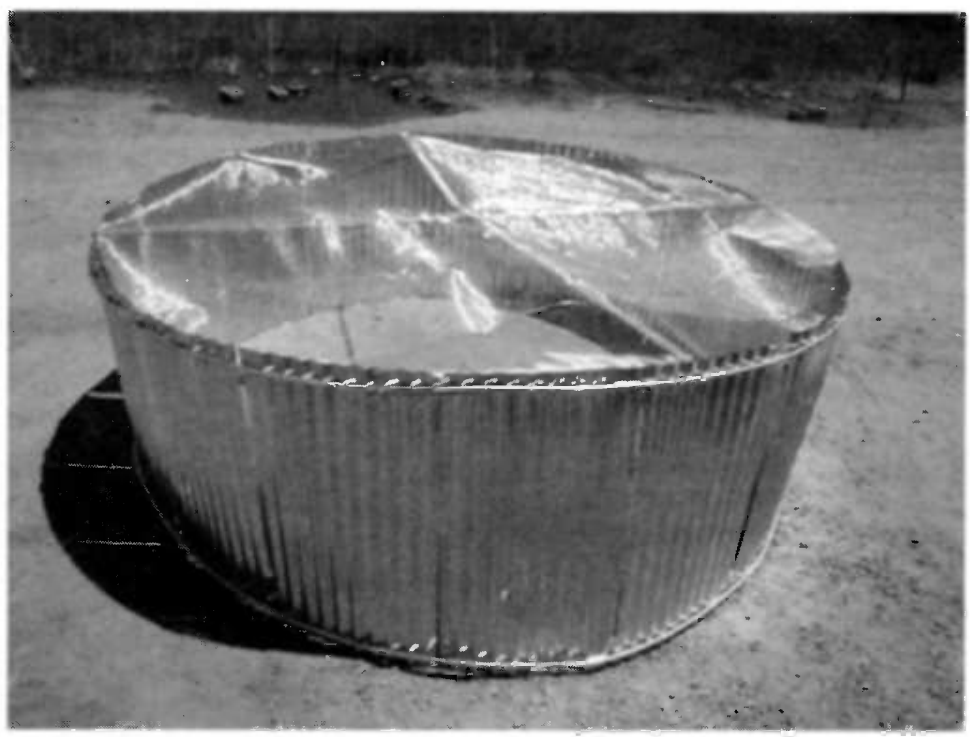

Fig. 1. A photograph of the $3.4 \mathrm{~m}$ diameter fire enclosure.

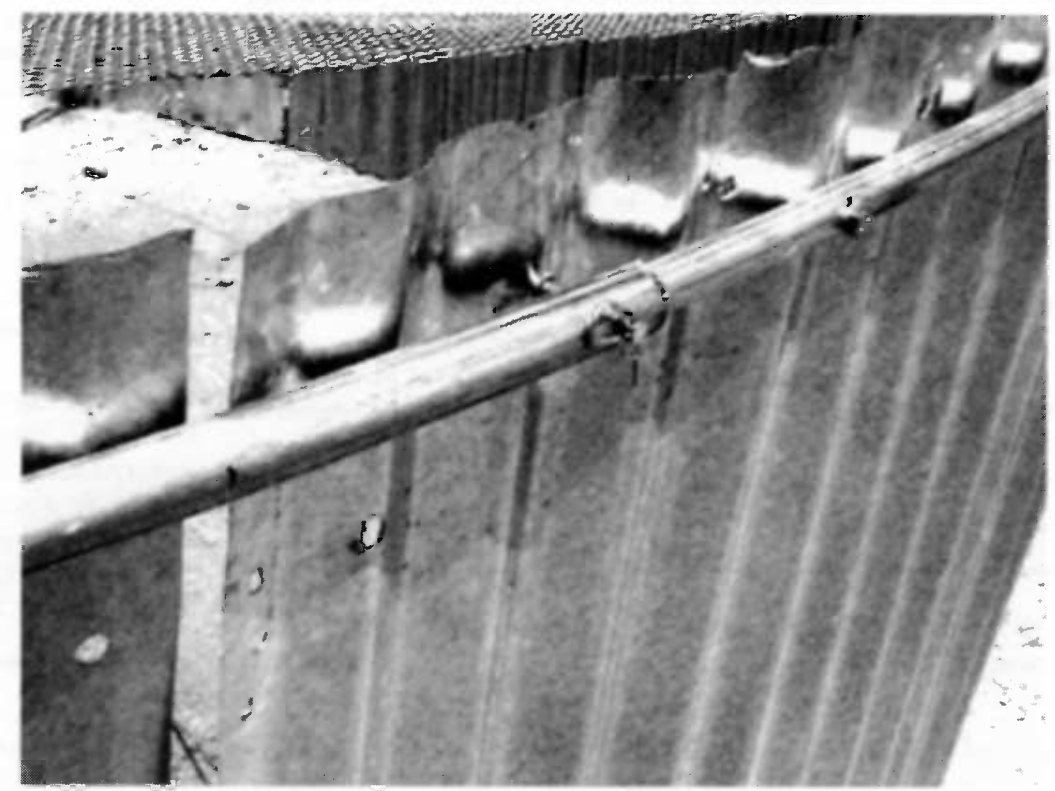

Fig. 2. Detail of pins and different-diameter electrical conduit used to connect the panels of the fire enclosure.

SAE sizes. Each section weighs $<20 \mathrm{~kg}$ and can be easily carried by 1 person. The materials cost $\$ 284$ and required about 20 worker-hours to construct.

We chose ungalvanized, 28-gauge sheetmetal as the material for our temperature monitoring tags. This material is preferable to aluminum because of its higher melting temperature and low cost. However, as a conductor, it is also subject to a brief "lag" in response to temperature changes as described by Cole et al. (1992). Tags were cut to $2.5 \times 10 \mathrm{~cm}$ size and striped with 20 Tempilaq $^{\circledR}$ temperature sensitive paints (Tempil, Inc., $\mathrm{S}$. Plainfield, N.J.) in ascending order of sensitivity, from $79-788^{\circ} \mathrm{C}$. The typical tem- perature interval between paints was $28^{\circ}$ C. We used a plant press to transport the tags as the paint strips are somewhat fragile when dry. Each tag cost about $\$ 0.10$ for materials and required about 2 minutes of labor to produce.

We used the fire enclosure to conduct burn treatments on circular, 3.4-m diameter plots as a component of a study of cheatgrass response (Bromus tectorum L.) to fire in central Nevada and central Utah. We conducted the burns in early October and mid-November, 2001 on the Nevada and Utah sites, respectively. The Nevada study area was in the Shoshone Range, on the Humboldt-Toiyabe National Forest, at $39^{\circ}$ north latitude, $117^{\circ} 30^{\prime}$ west longi- 
effects can be evaluated by collecting data on the intensity and duration of the fire or by observing fire parameters such as energy release, flame length, and residence time (Sapsis and Kauffman 1991). Ideally, this information is collected using thermocouples linked to data recorders (e.g., McDaniel et al. 1997) or evaluated using time-temperature curves and fuel loading for a particular fuel type (e.g., Wright et al. 1976). However, limitations imposed by study design, time, or other factors may make these methods impractical. A simpler, more economical method uses temperature-sensitive tablets ("Tempils"), which melt at certain temperatures (Shearer 1975). Temperature-sensitive paint, applied to ceramic tiles or mica plates (Gibson et al. 1990) or to aluminum tags (Cole et al. 1992) permits a large number of sensors for coverage of extensive areas or high sampling density. These methods do not permit a rigorous evaluation of the range of fire effects, but they are useful for examining 2- or 3-dimensional spatial variability of fire intensity (Cole et al. 1992).

\section{Materials and Methods}

Our fire enclosure (Fig. 1) was designed to treat a circular, 3.4-m diameter plot, prevent escape of embers and firebrands, be easily lifted and carried by 3-4 workers, and be transported in a standard-bed pickup truck. All materials used in assembly of the enclosure were purchased at local hardware stores. It was constructed of 16 panels of corrugated sheetmetal, each $122 \times 61 \mathrm{~cm}$, with $1-\mathrm{cm}$ gaps between panels for ventilation. For ease of transport and field portability, the enclosure was constructed in 4 sections of 4 panels each. The panels are joined by 3.8 $\mathrm{cm}$ (1.5-inch) hinges. Each section of 4 panels was reinforced by two, 244-cm lengths of $1.9-\mathrm{cm}(0.75$-inch) diameter electrical conduit that were shaped on a plumber's pipe bender. The reinforcements were attached to the panels at $10 \mathrm{~cm}$ from the top and bottom edges with bolts on $30-\mathrm{cm}$ centers. The sections were joined by short lengths of $2.5-\mathrm{cm}$ (1-inch) electrical conduit and straight pins (Fig. 2). To make a screen for the top of the fire enclosure, we assembled a framework from four, 180-cm long angle irons bolted together in the center and reinforced by a $2.5 \times 40 \times 0.5 \mathrm{~cm}$ piece of steel. We attached $0.6-\mathrm{cm}(0.25$-inch) hardware cloth, cut to a circular shape, to this framework. All fasteners used were standard

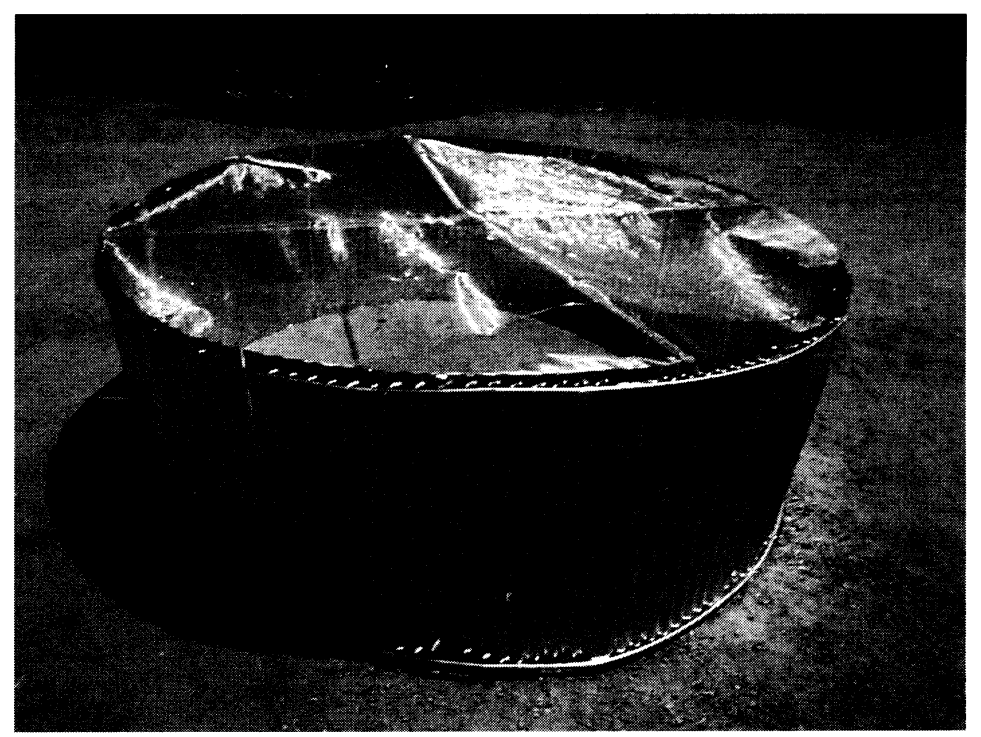

Fig. 1. A photograph of the $3.4 \mathrm{~m}$ diameter fire enclosure.

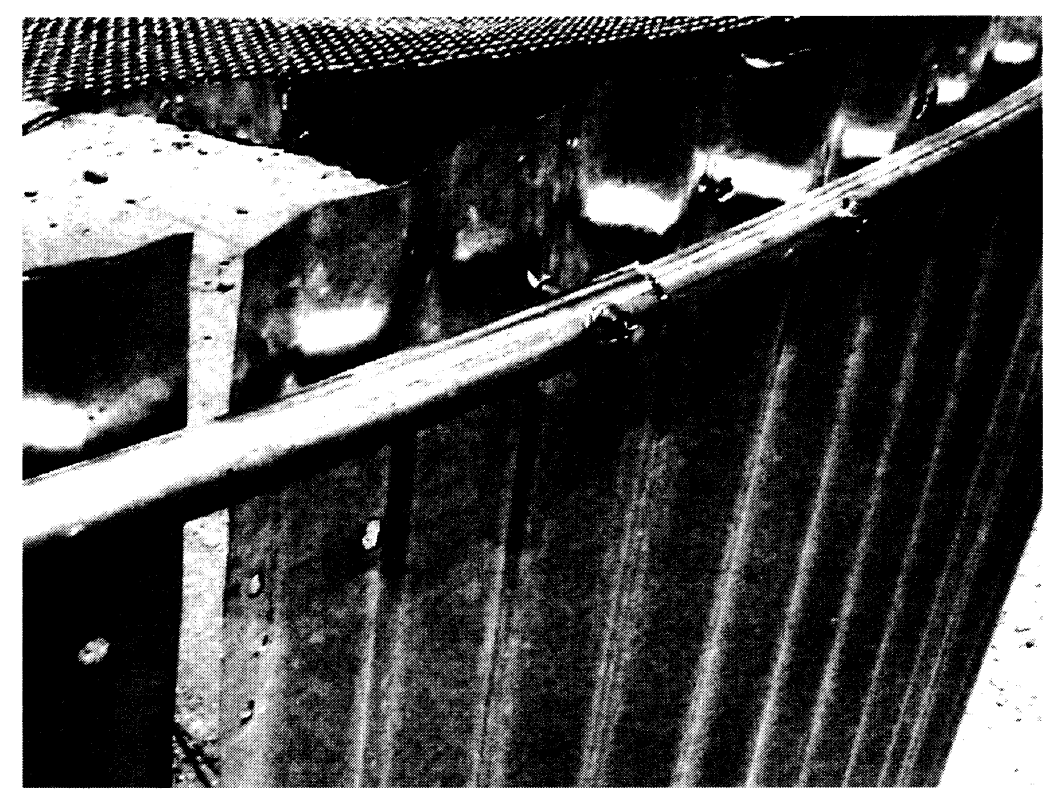

Fig. 2. Detail of pins and different-diameter electrical conduit used to connect the panels of the fire enclosure.

SAE sizes. Each section weighs $<20 \mathrm{~kg}$ and can be easily carried by 1 person. The materials cost $\$ 284$ and required about 20 worker-hours to construct.

We chose ungalvanized, 28-gauge sheetmetal as the material for our temperature monitoring tags. This material is preferable to aluminum because of its higher melting temperature and low cost. However, as a conductor, it is also subject to a brief "lag" in response to temperature changes as described by Cole et al. (1992). Tags were cut to $2.5 \times 10 \mathrm{~cm}$ size and striped with 20 Tempilaq ${ }^{\circledR}$ temperature sensitive paints (Tempil, Inc., S. Plainfield, N.J.) in ascending order of sensitivity, from $79-788^{\circ} \mathrm{C}$. The typical tem- perature interval between paints was $28^{\circ}$ C. We used a plant press to transport the tags as the paint strips are somewhat fragile when dry. Each tag cost about $\$ 0.10$ for materials and required about 2 minutes of labor to produce.

We used the fire enclosure to conduct burn treatments on circular, 3.4-m diameter plots as a component of a study of cheatgrass response (Bromus tectorum L.) to fire in central Nevada and central Utah. We conducted the burns in early October and mid-November, 2001 on the Nevada and Utah sites, respectively. The Nevada study area was in the Shoshone Range, on the Humboldt-Toiyabe National Forest, at $39^{\circ}$ north latitude, $117^{\circ} 30^{\prime}$ west longi- 
tude. Three sites were located in Underdown Canyon, at 1,950, 2,190, and 2,380 m elevation, and a fourth site was at the mouth of Barrett Canyon at 2,065 m. Vegetation (taxonomy after USDA Forest Service 2002) on the 1950 -m site consisted of Wyoming sagebrush (Artemisia tridentata Nutt. ssp. wyomingensis Beetle \& Young) with an understory of Sandberg bluegrass (Poa secunda J. S. Presl. var. secunda), needle-and-thread grass (Hesperostipa comata (Trin. \& Rupr.) Barkworth), bottlebrush squirreltail (Elymus elymoides (Raf.) Swezey) and cheatgrass. At the 2380-m site, the dominant shrub was mountain big sagebrush (Artemisia tridentata ssp. vaseyana (Rydb.) Beetle), cheatgrass was absent and Idaho fescue (Festuca idahoensis Elmer) was a significant understory component. The 2,190-m site had vegetation components of both the 1,950-m and 2,380-m sites. The Barrett Canyon site was cleared and overseeded with crested wheatgrass (Agropyron cristatum (L.) Gaertn.) in the early 1960's. Crested wheatgrass was the dominant plant on this site with a sparse cover of Wyoming big sagebrush. Precipitation for the water year (mid-Oct. 2000 to mid-Oct. 2001) preceding the treatments ranged from $14 \mathrm{~cm}$ at $2,000 \mathrm{~m}$ elevation to $28 \mathrm{~cm}$ at $2,400 \mathrm{~m}$, and was well below annual average for these types of sites (USDA Forest Service unpublished data). The Utah study area was in the East Tintic Range, on land administered by the Bureau of Land Management, at $40^{\circ}$ north latitude, $112^{\circ}$ west longitude. Three sites were located at $1,710 \mathrm{~m},, 2085$ m (Black Rock Canyon) and 2,270 m (Mill Canyon) elevation. Vegetation on the lowest site was dominated by Wyoming big sagebrush and bluebunch wheatgrass (Pseudoroegneria spicata (Pursh) A. Löve). The dominant shrub on the 2 upper sites was mountain big sagebrush, with Fendler bluegrass (Poa fendleriana (Steud.) Vasey) and spike fescue (Leucopoa kingii (S. Wats.) W.A. Weber) present on the 2,085-m and 2,270-m sites, respectively. Precipitation data for the Utah sites were not available.

Pre-burn moisture content of fuels at the Nevada sites ranged from $20.4-36.1 \%$ for needle-and-thread grass. For sagebrush, we evaluated leaves, $0.5-2.5 \mathrm{~cm}$ diameter, and $2.5-7.5 \mathrm{~cm}$ diameter fuels, which contained 43.3-50.9\%, 8.6-16.2\%, and 8.6$9.0 \%$ moisture by weight, respectively. The latter 2 categories correspond approximately to 10-hour and 100-hour fuels (after Wright and Bailey 1982). We did not collect fuel moisture data on the Utah sites. Air temperature during the treatments in Nevada ranged from $12-20^{\circ} \mathrm{C}$ and relative humidity was $15-25 \%$. Air temperature and humidity ranges for the Utah treatments were $13-16^{\circ} \mathrm{C}$ and $30-47 \%$. Fuel loading was generally low, especially at the lower elevation sites. To ensure uniform burn characteristics, we dispersed $4.5 \mathrm{~kg}$ of dry straw in each plot, yielding a fuel loading of $>5000 \mathrm{~kg} \mathrm{ha}^{-1}$ on all plots.

We burned 9 plots on each of the 7 sites. Before conducting the burns, we cleared all woody vegetation within $0.5 \mathrm{~m}$ of the plot. We placed temperature tags on 3 microsites (under shrub, under grass, and on bare ground) and at 2 depths (on the litter surface, or on the soil surface if no litter was present; and $2 \mathrm{~cm}$ below the soil surface) within each microsite, for a total of 6 measurements per plot. We marked the tag locations with steel rods. We then positioned the enclosure, added the straw, moistened the periphery of the enclosure with a mister nozzle, and ignited the plot with a drip torch containing a diesel/gasoline mix. We allowed 15 minutes on the
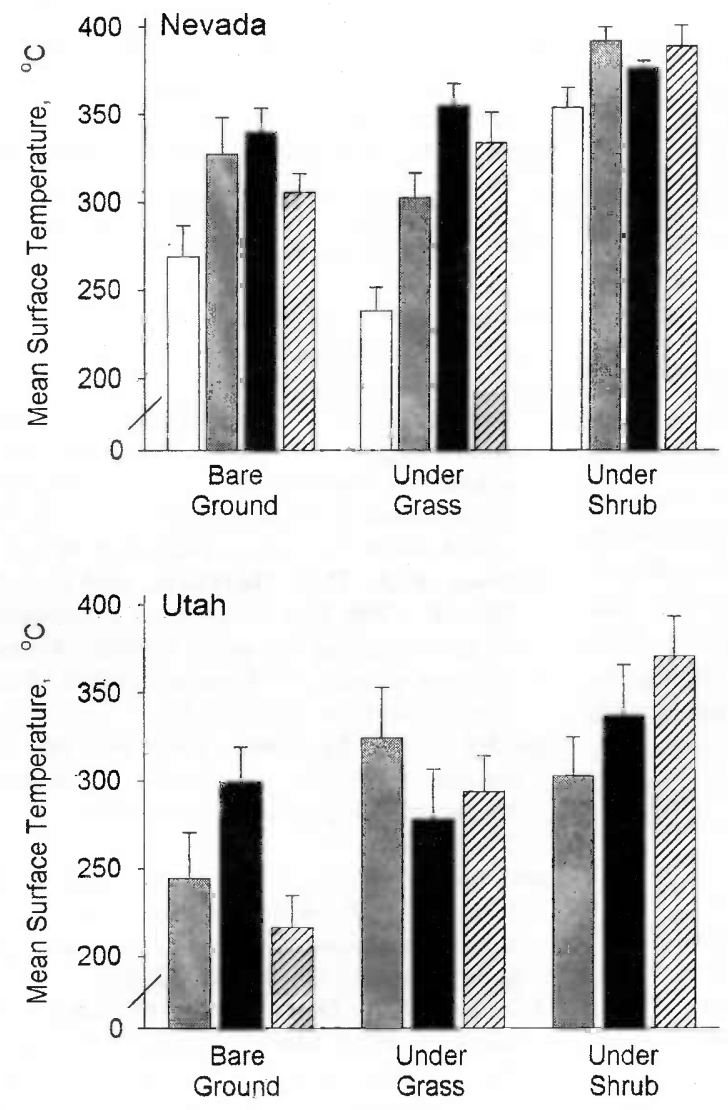

Sagebrush $1710 \mathrm{~m}$ एבzes Black Rock Canyon $2270 \mathrm{~m}$

Site: $P<0.8410$

Microsite: $P<0.0001$

Fig. 3. The differences in the surface temperatures $\left({ }^{\circ} \mathrm{C}\right)$ among bare ground, under grass, and under shrub microsites on the study sites in Nevada and Utah. Values are mean+S.E. 
tude. Three sites were located in Underdown Canyon, at 1,950, 2,190, and 2,380 m elevation, and a fourth site was at the mouth of Barrett Canyon at 2,065 m. Vegetation (taxonomy after USDA Forest Service 2002) on the 1950-m site consisted of Wyoming sagebrush (Artemisia tridentata Nutt. ssp. wyomingensis Beetle \& Young) with an understory of Sandberg bluegrass (Poa secunda J. S. Presl. var. secunda), needle-and-thread grass (Hesperostipa comata (Trin. \& Rupr.) Barkworth), bottlebrush squirreltail (Elymus elymoides (Raf.) Swezey) and cheatgrass. At the 2380-m site, the dominant shrub was mountain big sagebrush (Artemisia tridentata ssp. vaseyana (Rydb.) Beetle), cheatgrass was absent and Idaho fescue (Festuca idahoensis Elmer) was a significant understory component. The $2,190-\mathrm{m}$ site had vegetation components of both the 1,950-m and 2,380-m sites. The Barrett Canyon site was cleared and overseeded with crested wheatgrass (Agropyron cristatum (L.) Gaertn.) in the early 1960's. Crested wheatgrass was the dominant plant on this site with a sparse cover of Wyoming big sagebrush. Precipitation for the water year (mid-Oct. 2000 to mid-Oct. 2001) preceding the treatments ranged from $14 \mathrm{~cm}$ at $2,000 \mathrm{~m}$ elevation to $28 \mathrm{~cm}$ at $2,400 \mathrm{~m}$, and was well below annual average for these types of sites (USDA Forest Service unpublished data). The Utah study area was in the East Tintic Range, on land administered by the Bureau of Land Management, at $40^{\circ}$ north latitude, $112^{\circ}$ west longitude. Three sites were located at 1,710 m, ,2085 m (Black Rock Canyon) and 2,270 m (Mill Canyon) elevation. Vegetation on the lowest site was dominated by Wyoming big sagebrush and bluebunch wheatgrass (Pseudoroegneria spicata (Pursh) A. Löve). The dominant shrub on the 2 upper sites was mountain big sagebrush, with Fendler bluegrass (Poa fendleriana (Steud.) Vasey) and spike fescue (Leucopoa kingii (S. Wats.) W.A. Weber) present on the 2,085-m and 2,270-m sites, respectively. Precipitation data for the Utah sites were not available.

Pre-burn moisture content of fuels at the Nevada sites ranged from $20.4-36.1 \%$ for needle-and-thread grass. For sagebrush, we evaluated leaves, $0.5-2.5 \mathrm{~cm}$ diameter, and $2.5-7.5 \mathrm{~cm}$ diameter fuels, which contained 43.3-50.9\%, 8.6-16.2\%, and 8.6$9.0 \%$ moisture by weight, respectively. The latter 2 categories correspond approximately to 10-hour and 100-hour fuels (after Wright and Bailey 1982). We did not collect fuel moisture data on the Utah sites. Air temperature during the treatments in Nevada ranged from $12-20^{\circ} \mathrm{C}$ and relative humidity was $15-25 \%$. Air temperature and humidity ranges for the Utah treatments were $13-16^{\circ} \mathrm{C}$ and $30-47 \%$. Fuel loading was generally low, especially at the lower elevation sites. To ensure uniform burn characteristics, we dispersed $4.5 \mathrm{~kg}$ of dry straw in each plot, yielding a fuel loading of $>5000 \mathrm{~kg} \mathrm{ha}^{-1}$ on all plots.

We burned 9 plots on each of the 7 sites. Before conducting the burns, we cleared all woody vegetation within $0.5 \mathrm{~m}$ of the plot. We placed temperature tags on 3 microsites (under shrub, under grass, and on bare ground) and at 2 depths (on the litter surface, or on the soil surface if no litter was present; and $2 \mathrm{~cm}$ below the soil surface) within each microsite, for a total of 6 measurements per plot. We marked the tag locations with steel rods. We then positioned the enclosure, added the straw, moistened the periphery of the enclosure with a mister nozzle, and ignited the plot with a drip torch containing a diesel/gasoline mix. We allowed 15 minutes on the low elevation plots and 25 minutes on the high elevation plots for fuels to be consumed, and then quenched the entire plot with the mister nozzle, taking care not to disturb the soil. We recovered the temperature monitoring tags and recorded the number of paint strips remaining on the tags.

A preliminary analysis indicated the data would be best suited to nonparametric statistical methods. We used the Multiple Response Permutation Procedure (MRPP) to analyze the temperature data (Mielke et al. 1976, Petrondas and Gabriel 1983). Significance values indicate the probability of a smaller MRPP test statistic $(\mathrm{P}[<\delta])$.

\section{Results and Discussion}

The fire enclosures were effective in containing the fire for the fuel loading $\left(\sim 5000 \mathrm{~kg} \mathrm{ha}^{-1}\right)$ in the study. Despite occasional flame lengths of up to $5 \mathrm{~m}$, no escape or "spotting" occurred. The under shrub microsite exhibited significantly higher peak surface temperatures than bare ground or under grass microsites (Fig. 3),
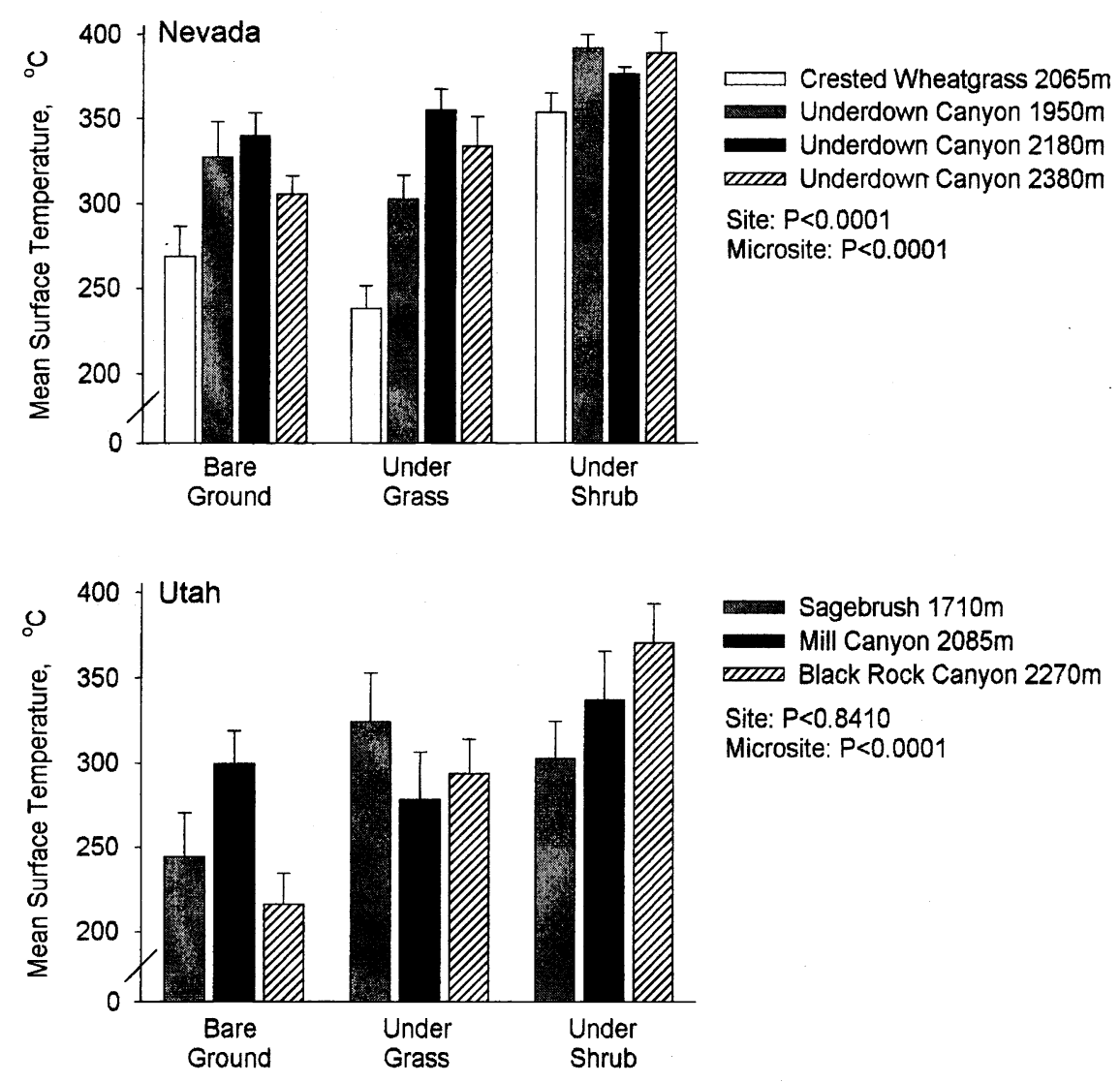

Fig. 3. The differences in the surface temperatures $\left({ }^{\circ} \mathrm{C}\right)$ among bare ground, under grass, and under shrub microsites on the study sites in Nevada and Utah. Values are mean+S.E. 
averaging $381^{\circ} \mathrm{C}$ versus 310 and $307^{\circ} \mathrm{C}$, respectively ( $\mathrm{P}<0.0001$ for both comparisons) at the Nevada sites, and $337^{\circ} \mathrm{C}$ versus 299 and $253^{\circ} \mathrm{C}$, respectively $(\mathrm{P}=$ 0.0176 and $\mathrm{P}<0.0001)$ at the Utah sites. We attribute the difference to the higher fuel loading of the under shrub microsite, and to woody embers falling on or near the tags. The difference in peak surface temperatures for the other 2 microsites (under grass and bare ground) was not significant at the Nevada sites, but was significant on the Utah sites $(\mathrm{P}=0.0175)$. There were no significant differences in peak surface temperatures among the 3 sites in Underdown Canyon (Nevada), or among the 3 Utah sites, but the Barrett Canyon (Nevada) crested wheatgrass site was cooler overall than the Underdown Canyon sites $(\mathrm{P}=0.0008, \mathrm{P}<0.0001$, and $\mathrm{P}$ $=0.0003$ for pairwise comparisons with the Underdown 1950-, 2190-, and 2380-m sites, respectively). Differences in fuel loading between these 2 microsites were probably minimized by the addition of straw. Overall, peak surface temperatures averaged $51^{\circ} \mathrm{C}$ higher $(\mathrm{P}<0.0001)$ on the Nevada sites than on the Utah sites. We attribute this to the later date and cooler, wetter conditions prevailing for the Utah burns.

Peak temperatures for tags at the $2-\mathrm{cm}$ depth were generally below $79^{\circ} \mathrm{C}$, the lowest detectable temperature. We deployed 160 tags at the $2-\mathrm{cm}$ depth, only 54 of which recorded temperatures above $79^{\circ} \mathrm{C}$. Most $(70 \%)$ of the 54 readings above $79^{\circ} \mathrm{C}$ were in the under shrub microsite.

The peak surface temperatures detected in this test were within the ranges reported for snowberry shrubland (Bailey and Anderson 1980), chaparral (DeBano et al. 1977) and sandhill grassland (Gibson et al. 1990). They were consistent with temperature ranges used in laboratory experiments simulating rangeland fire effects (Blank and Young 1998, Blank et al. 1994). The lack of temperature responses at the $2-\mathrm{cm}$ depth was probably due to the insulating effect of the soil, and was consistent with subsurface temperatures noted in Australian shrubland (Bradstock et al. 1992) and chaparral (DeBano et al. 1977).

The small plot fire enclosure described here can be inexpensively constructed with readily available materials, easily transported and efficiently deployed in the field. It effectively prevents spread of fire to nearby plots or to the surrounding landscape. The plot burning and fire temperature assessment methods are also simple and inexpensive. The techniques are not adequate where precision control of fire temperatures and absolutely uniform heat distribution are required, or where researchers desire precise knowledge of the timing and magnitude of temperature changes, but they are adequate for evaluating the spatial variability of burn intensity. They are appropriate to research where a relatively uniform burn treatment is desired, but funds, study design, or time do not permit larger burns, pre-burn standing crop estimation, or more elaborate temperature monitoring.

\section{Literature Cited}

Bailey, A.W. and M.L. Anderson. 1980. Fire temperatures in grass, shrub and aspen forest communities of central Alberta. J. Range Manage. 33:37-40.

Blank, R.R. and J.A. Young. 1998. Heated substrate and smoke: Influence on seed emergence and plant growth. J. Range Manage. 577-583.

Blank, R.R., F. Allen, and J.A. Young. 1994. Extractable anions in soils following wildfire in a sagebrush-grass community. Soil Sci. Soc. Amer. J. 58:564-570.

Bradstock, R.A., T.D. Auld, M.E. Ellis, and J.S. Cohn. 1992. Soil temperatures during bushfires in semi-arid, mallee shrublands. Aust. J. Ecol. 17:433-440.

Britton, C.M. and H.A. Wright. 1979. A portable burner for evaluating effects of fire on plants. J. Range Manage. 32:475-477.

Cole, K.L., K.F. Klick, and N.B. Pavlovic. 1992. Fire temperature monitoring during experimental burns at Indiana Dunes National Lakeshore. Natur. Areas J. 12:177-183.

DeBano, L.F., P.H. Dunn, and C.E. Conrad. 1977. Fire's effect on physical and chemical properties of chaparral soils. In: H.A. Mooney and C.E. Conrad (tech. coords.) Proceedings of the symposium on the environmental consequences of fire and fuel management in Mediterranean ecosystems. USDA Forest Serv. Gen. Tech. Rep. WO-3.

Gibson, D.J., D.C. Hartnett, and G.L.S. Merrill. 1990. Fire temperature heterogeneity in contrasting fire prone habitats: Kansas tallgrass prairie and Florida sandhill. Bull. Torrey Bot. Club 117:349-356.

Kutiel, P. and M. Inbar. 1993. Fire impacts on soil nutrients and soil-erosion in a Mediterranean pine forest plantation. Catena 20:129-139.

McDaniel, K.C., C.R. Hart, and D.B. Carroll. 1997. Broom snakeweed control with fire on New Mexico blue grama rangeland. J. Range Manage. 50:652-659.

Mielke, P.W. Jr., K.J. Berry, and E.S. Johnson. 1976. Multi-Response Permutation Procedures for a priori classifications. Communications in Statistics: Theory and Methods A14:1409-1424

Perez, B. and J.M. Moreno. 1998. Methods for quantifying fire severity in shrubland fires. Plant Ecol. 139:91-101.
Petrondas, D.A. and K.R. Gabriel. 1983. Multiple comparisons by rerandomization tests. J. Amer. Statistical Assoc. 78:949-957.

Sapsis, D.B. and J.B. Kauffman. 1991. Fuel consumption and fire behavior associated with prescribed fires in sagebrush ecosystems. Northw. Sci. 65:173-179.

Shearer, R.C. 1975. Seedbed characteristics in western larch forests after prescribed burning. USDA Forest Serv. Res. Paper INT-167. Ogden, Ut.

Tanaka, S., T. Ando, S. Funakawa, C. Sukhrun, T. Kaewkhongkha, and $K$. Sakurai. 2001. Effect of burning on soil organic matter content and $\mathrm{N}$-mineralization under shifting cultivation system of Karen people in northern Thailand. Soil Sci. Plant Nutr. 47:547-558.

USDA Forest Service. 2002. Fire Effects Information System Plant Database. Rocky Mountain Res. Sta., Fire Sci. Lab., Missoula, Mont. www.fs.fed.us/database/feis

Whelan, R.J. 1995. The ecology of fire. Cambridge Univ. Press, Cambridge, U.K

Wright, H.A. and A. W. Bailey. 1982. Fire ecology: United States and Southern Canada. John Wiley and Sons, New York, N.Y.

Wright, H.A. and J.O. Klemmedson. 1965. Effects of fire on bunchgrasses of the sagebrush-grass region in southern Idaho. Ecol. 46:680-688.

Wright, H.A., S.C. Bunting, and L.F. Neuenschwander. 1976. Effect of fire on honey mesquite. J. Range Manage. 29:467-471. 


\title{
Consumption and dispersion of mesquite seeds by rumi- nants
}

\author{
CHARLES L. KNEUPER, CODY B. SCOTT, AND WILLIAM E. PINCHAK
}

Authors are former Graduate Assistant, Associate Professor, Department of Agriculture, Angelo State University, San Angelo, Tex; Professor, Texas Agricultural Experiment Station, Vernon, Tex.

Abstract

Consumption of mesquite (Prosopis glandulosa Torr. var glandulosa) fruit by ruminants is an important component of seed dispersal. Two experiments were conducted to estimate the role of livestock and wildlife in the dispersion of mesquite fruit. In Experiment 1, 3 trials were conducted to determine preference for mesquite fruit by different species of livestock, intake relative to fruit maturity, and seed survival of digestion. Cattle, sheep, and goats were offered immature (IM), mature off the tree (MT), or mature off the ground (MG) fruit to quantify intake and seed survival of digestion. Germination of seeds surviving digestion was also assessed. Experiment 2 assessed rate of pod disappearance from pastures with and without livestock grazing and attempted to quantify seed loss to wildlife. In Experiment 1, livestock consumed more $(P<0.05)$ mature than immature fruit; sheep and goats consumed more fruit than cattle on a body weight basis. Seed survival was greater $(P<0.05)$ from cattle than from sheep or goats. The number of seeds remaining intact after digestion was greater for mature fruit. Germination of seeds surviving digestion was similar $(P>0.05)$ to seeds that experienced natural weathering for 6 months. In Experiment 2, the presence or absence of livestock did not affect the disappearance of seeds; seeds disappeared from the ground within 3 weeks in 1999 and 5 weeks in 2000 presumably by wildlife. Deer, raccoons, skunks, bobcats, turkeys, and other birds visited plots with fresh mesquite fruit. Collectively, these results suggest that cattle readily consume and disperse viable mesquite seeds; sheep and goat consumption of mesquite fruit may reduce the number of viable seeds; and mesquite fruit may only remain on the ground for a short period of time even without livestock grazing because of consumption by wildlife.

Key Words: Prosopis, germination, digestion, fecal dispersal, phenology, encroachment

Across Texas, an ever-increasing density of mesquite (Prosopis glandulosa Torr. var. glandulosa) has reduced herbaceous production on rangelands (Bedunah and Sosebee 1984, Cuda and DeLoach 1998). Mesquite infests about 22 million ha of rangeland in Texas (Jacoby et al. 1990a), and control of mesquite is a major concern for ranchers (Ueckert 1974, Heitschmidt and Dowhower 1991). Herbicide application is the most common method for controlling large areas of mesquite, but most treat-

Research was funded by USDA NRI program as grant number 98-35315-6045. Manuscript accepted 8 Aug. 2002.

\section{Resumen}

El consumo de los frutos del mezquite (Prosopis glandulosa Torr. var glandulosa) por los rumiantes es un componente componente de la dispersión de semilla. Se condujeron dos experimentos para estimar el papel del ganado doméstico y la fauna silvestre en la dispersión de frutos de "Mesquite". En el experimento 1 se realizaron 3 ensayos para determinar la preferencia del fruto de "Mesquite" por diferentes especies de ganado, el consumo en relación a la madurez del fruto y la sobrevivencia de la a la digestión. A bovinos, caprinos y ovinos se les ofreció frutos inmaduros (IM), frutos maduros tomados del árbol (MT) y frutos maduros tomados del suelo (MG) para cuantificar el consumo y sobrevivencia a la digestión. El experimento 2 evaluó la tasa de desaparición de vainas de potreros con y sin apacentamiento de ganado y se intento cuantificar la perdida de semilla para la fauna silvestre. En el experimento 1 el ganado consumió mas frutos maduros que inmaduros $(P<0.05)$, los caprinos y ovinos consumieron mas frutos que los bovinos, esto expresado en base al peso corporal. La sobrvivencia de la semilla fue mayor ( $P$ $<0.05$ ) en los bovinos que en los ovinos o caprinos. El número de semillas que permanecieron intactas después de la digestión fue mayor en los frutos maduros. La germinación de las semillas sobrevivientes a la digestión fue similar $(P>0.05)$ a la de semillas expuestas a intemperización natural por 6 meses. En el experimento 2 la presencia o ausencia de ganado doméstico no afectó la tasa de desaparición de semillas, las semillas desaparecieron del suelo en 3 semanas en 1999 y en 5 semanas en el 2000, esto presumiblemente por efecto de la fauna. Venados, mapaches, zorrillos, pumas, pavos y otras aves visitaron las parcelas con frutos frescos de "Mesquite". Estos resultados sugieren que el ganado bovino si consume y dispersa semillas viables de "Mesquite", el consumo de frutos de "Mesquite" por ovinos y caprinos puede reducir el número de semillas viables y el fruto del "Mesquite" puede permanecer en el suelo solo por un periodo corto de tiempo, aun sin apacentamiento de ganado, debido al consumo de este por la fauna silvestre.

ments only last for a few years (e.g., 5-10) because some mesquite trees resprout after herbicide treatment and seedlings readily establish (Jacoby et al. 1982, 1990b, Teague et al. 1997).

Encroachment and reinvasion of mesquite into grasslands is accelerated by livestock consuming and then dispersing seeds (Gibbens et al. 1992, Lerner and Peinetti 1996, Kramp et al. 1998). Mesquite produces a seed pod with 10-20 seeds/pod depending on growing conditions. Seeds are encapsulated in a hard coat that must be scarified before rapid germination will 
occur; passage of seeds through the ruminant digestive tract apparently enhances seed germination potential (Scifres and Brock 1969, 1972, Cuda and DeLoach 1998), and livestock are a likely primary dispersal vector for mesquite (Kramp et al. 1998).

Little information is available on when livestock consume mesquite fruit relative to fruit maturity and on seed survival from different stages of fruit maturity. The relative importance of animals as dispersal agents of mesquite seeds may depend on intake patterns relative to seed availability and maturity (Kramp et al. 1998). This study quantified intake and survival of digestion of mesquite seeds from different stages of fruit maturity by 3 species of livestock. In addition, we identified disappearance rate of fruit from pastures with and without the presence of livestock, and we attempted to identify other species that may consume and disperse mesquite fruit.

\section{Methods}

This research was conducted at the Angelo State University Management, Instruction, and Research (MIR) Center located in the Rolling Plains region of Texas, $9.7 \mathrm{~km}$ north of San Angelo, Tex $\left(30^{\circ} \mathrm{N}, 100^{\circ} \mathrm{W}\right)$. Five freshly weaned Angus/Beefmaster crossbred steers ( 5 months-old, weight $250 \mathrm{~kg}$ ), 5 castrated Ramboullet sheep (4 months-old, weight $40 \mathrm{~kg}$ ), and 5 castrated Boer/Spanish goats ( 3 months-old, weight $25 \mathrm{~kg}$ ) were placed in individual pens and offered current growing season mesquite fruit from different stages of maturity on a daily basis. Sheep and goats were placed in $1.5 \times 1.5$ $\mathrm{m}$ metabolism stalls to facilitate fecal collections for Experiment 1. Steers were individually placed in $4 \times 7 \mathrm{~m}$ pens and fecal collection bags were attached to the steers. Fecal bags were emptied twice daily because of the volume of feces produced. Fecal samples for each steer were combined to estimate daily fecal production/animal. All animals were fed (1.5\% $\mathrm{BW}$ ) an alfalfa hay/concentrate basal ration (CP\% 12.3, TDN 61\%, DE $2.7 \mathrm{mcal}$ $\left.\mathrm{kg}^{-1}\right)$ to meet maintenance requirements (NRC 1981, 1984, 1996). Fresh water and a calcium/phosphorus mineral with trace elements were provided ad libitum. All animals were housed in the same open-air research facility under similar environmental conditions.

\section{Experiment 1}

To assess intake of mesquite fruit from different stages of maturity, fruit was collected daily from several randomly selected trees on the MIR Center. Fruit was arbitrarily categorized as immature attached to the tree (IM), mature attached to the tree (MT), and mature on the ground (MG). Immature fruit was identified as green pods with seeds that appeared underdeveloped. Mature attached to the tree (MT) were pods that were beginning to change from the immature green color to a mature red-brown color. The fruit was filled out and seeds appeared fully developed. Mature on the ground (MG) represented the mature fruit that had completely changed to the red-brown color and had recently fallen to the ground. Any fruit that appeared mature and fell to the ground during harvesting was classified as MG.

Intake of 3 classes of mesquite fruit was determined in Trial 1. Livestock (cattle, sheep, and goats) were fed a single class of mesquite fruit $(0.5 \% \mathrm{BW})$ at 0800 hours each morning for $10 \mathrm{~min}$ over 7 days. Feeding level was based on the amount of beans consumed in a similar feeding trial (Kneuper and Scott 1998). The trial was divided into 3 phases. In the first 7 days, individual steers, sheep, and goats were fed IM fruit. Phase 2 consisted of feeding MT fruit. Mature on the ground fruit was fed during phase 3 . Refusals were weighed to determine intake of each class of fruit. After each class of fruit was fed individually, all 3 stages of fruit development were fed simultaneously in separate containers to quantify preference. Individuals were offered a choice between fruit classes for $10 \mathrm{~min}$ each day for 7 days. If fruits from any maturity stage were completely consumed during the preference trial, all remaining fruit was removed immediately.

In Trial 2, the percent of intact seeds in feces from different stages of maturity was determined by feeding seeds and collecting feces. Each stage of seed maturity was fed once and total fecal collections were utilized to recover seeds for 4 days thereafter. Before feeding seeds from a particular maturity stage, a 5-day rest period was used to ensure any seeds already in an individual's digestive system had passed. Other studies have shown that seeds will pass up to 4 days post-ingestion (Armke and Scott 1999). The number of seeds fed was based on feeding $0.1 \% \mathrm{BW}$ of fruit to an animal. This level was sufficient for seed recovery in feces in a previous study (Kneuper and Scott 1998). Before feeding each stage, representative samples of each stage were weighed and the number of seeds were counted. The average number of seeds fed was used to calculate the percent of intact seeds surviving digestion.

Feces were collected twice daily for cattle and once daily for sheep and goats, and total fecal weight was recorded. Subsamples were taken to estimate the number of seeds surviving digestion. Fecal subsamples were washed through a series of screens and seeds were separated; whole seeds that were found, with or without an exocarp, constituted survival of digestion.

In Trial 3, germination was determined for seeds that had remained on the ground and weathered for 6 months, unweathered seeds, and for MT and MG seeds collected from cattle, sheep, and goat feces from Trial 2. One hundred and twenty seeds were used in the study, 15 seeds from each treatment. Immature seeds (IM) were excluded from this trial because few were collected from feces. Seeds from the ground that had weathered were kept in cages to prevent loss to herbivory.

Seeds that were sealed in dry containers and stored in the laboratory were included in the trial as an unweathered control. One half of the unweathered seeds were dissected and the exocarp was removed to assess seed germination without the presence of the exocarp. All seeds were stored at $5^{\circ} \mathrm{C}$ from time of collection until initiation of the germination test.

Fifteen seeds of each treatment were placed between sheets of moistened filter paper in petri dishes, with 5 seeds/dish. Samples were placed in na oven set at $30^{\circ} \mathrm{C}$ (Scifres and Brock 1969, 1972). Seeds were checked daily for germination for 21 days. Once seeds germinated, they were removed from the petri dishes. Filter paper was moistened as needed to maintain imbibition.

\section{Experiment 2}

This study was conducted for 2 years. In 1999, we determined the length of time that fruit remained on the ground. Ten mature Angus cows, 40 Rambouillet ewes, and 50 Boer-Spanish cross nannies were placed in separate 30 ha pastures at a stock density of $1 \mathrm{AU} / 10$ ha. One additional pasture was ungrazed by livestock. Each pasture was dominated by an overstory of mesquite and an understory of sideoats grama (Bouteloua curtipendula (Michx.) Torr.), buffalograss (Buchloe dactyloides (Nutt.) Engelm.), threeawns (Aristida sp. L), and K.R. bluestem (Bothriochloa ischaemum L.). In each pasture, 2 transects $250 \mathrm{~m}$ in length were randomly 
established with six, $0.33 \mathrm{~m}^{2}$ plots at $50 \mathrm{~m}$ spacings on each transect. Twenty-five mesquite pods were placed in each plot and monitored weekly for 4 weeks to determine disappearance rates of fruit. There were only 4 pastures available for this experiment. Thus, class of livestock as a treatment effect was not replicated.

In 2000 , the rate of fruit disappearance and consumption of mesquite fruit by other animal species was assessed. Sixteen, 1-m diameter plots containing 20 fresh mature mesquite pods each were placed throughout the MIR Center. Plots were placed adjacent to existing dirt roads, $0.5 \mathrm{~km}$ apart, and $20 \mathrm{~m}$ from the edge of the road. The pathway was systematically chosen to represent all of the major vegetation types on the MIR Center. Crushed lime was evenly spread across the plot on every third plot ( $\mathrm{n}=5$ plots). The crushed lime was checked daily for 2 consecutive days to identify tracks of animals visiting the mesquite pod plots (Woods 1959).

\section{Statistical analysis}

For Experiment 1, Trial 1 (intake and preference of maturity classes) and Trial 2 (seed survival), data were analyzed using analysis of variance for repeated measures (Hicks 1993). Stage of maturity and species of livestock were the main effects, and day of data collection was the repeated measure. Individual animals served as replications nested within species of livestock and maturity class. Differences in germination were assessed in Trial 3 using analysis of variance with replications (petri dishes) nested within livestock species and maturity class of seeds. Differences among means were separated using a least significant difference when $\mathrm{P}$ $<0.05$ (Gomez and Gomez 1984). Data was analyzed using the statistical computer package JMP (SAS 1994).

For Experiment 2, average disappearance rate of fruit was calculated. The percent of visitation by different species of wildlife was also calculated in 2000 . Traditional statistical comparisons were not appropriate for Experiment 2 because treatment effect was not replicated and because the experimental protocol differed between years.

\section{Results}

\section{Experiment 1, Trial 1}

Intake of mesquite fruit differed by class of livestock and stage of maturity resulting

Table 1. Intake ( $\mathrm{g} \mathrm{kg}^{-1} \mathrm{BW}$ ) of 3 maturity classes of mesquite fruit by 3 species of livestock. Livestock were offered $0.5 \% \mathrm{BW}$ of each maturity class singly for $10 \mathrm{~min}$ daily for $\mathbf{7}$ days to determine intake.

\begin{tabular}{|c|c|c|c|c|}
\hline \multirow[b]{2}{*}{ Livestock Species } & \multicolumn{4}{|c|}{ Stage of development } \\
\hline & IM & MT & MG & Across Maturity Classes \\
\hline & \multicolumn{4}{|l|}{ - } \\
\hline Cattle & $0.4^{\mathrm{e}}$ & $2.7^{\text {cd }}$ & $2.4^{\mathrm{d}}$ & $1.8^{\mathrm{B}}$ \\
\hline Sheep & $3.8^{\mathrm{b}}$ & $5.0^{\mathrm{a}}$ & $4.7^{\mathrm{a}}$ & $4.5^{\mathrm{A}}$ \\
\hline Goats & $3.0^{\mathrm{c}}$ & $4.6^{\mathrm{a}}$ & $5.0^{\mathrm{a}}$ & $4.2^{\mathrm{A}}$ \\
\hline \multicolumn{2}{|c|}{ Across Livestock Species } & $2.4^{\mathrm{B}}$ & $4.0^{\mathrm{A}}$ & $4.0^{\mathrm{A}}$ \\
\hline
\end{tabular}

$\overline{a-e}$ Values within columns and rows with different superscripts differ $(\mathrm{P}<0.05)$.

A-B Values for different stages of fruit maturity or for different classes of livestock with different superscripts differ $(\mathrm{P}<$ $0.05)$

in a significant $(\mathrm{P}<0.05)$ class of livestock by stage of maturity interaction (Table 1). All 3 classes of livestock ate less immature fruit. However, sheep consumed more immature attached to tree (IM) fruit than goats which consumed more IM than cattle. Sheep and goats also consumed more mature attached to tree (MT) and mature on ground (MG) fruit than cattle on a body weight basis. When comparing intake of the 2 mature stages of fruit (MT and MG), there were no differences across species of livestock. Intake was similar across days of collection.

When livestock were offered a choice of the 3 maturity stages of fruit, cattle, sheep, and goats ate no immature fruit. Intake of MT and MG was similar among all 3 species of livestock $(\mathrm{P}>0.05 ; 0.2$ vs. 0.2 $\mathrm{g} \mathrm{kg}^{-1} \mathrm{BW}$ ).

\section{Experiment 1, Trials 2 and 3}

We were unable to estimate seed survival of IM fruit for cattle because they ate few IM fruits in Trial 1. Roughly equal proportions of seeds were retrieved from feces in each of the first 3 days for each animal species and maturity class (data not shown). There was almost no survival of

Table 2. The percent (\%) of each maturity class of seed that was found intact in the feces of 3 species of livestock. The percent of intact seeds in feces was determined by feeding each maturity class of fruit separately $(0.1 \% \mathrm{BW})$ and separating seeds from feces for 4 days.

\begin{tabular}{lccc}
\hline \hline & \multicolumn{3}{c}{ Stage of development } \\
\cline { 2 - 4 } Livestock Species & IM & MT & MG \\
\hline & - & & \\
& & & \\
Cattle & -- & $22.1^{\mathrm{b}}$ & $92.3^{\mathrm{a}}$ \\
Sheep & $0.3^{\mathrm{c}}$ & $0.8^{\mathrm{c}}$ & $11.3^{\mathrm{c}}$ \\
Goats & $0.0^{\mathrm{c}}$ & $0.0^{\mathrm{c}}$ & $9.2^{\mathrm{c}}$ \\
\hline
\end{tabular}

*Survival of IM was not determined for cattle.

${ }^{\mathrm{a}-\mathrm{c}}$ Values within columns and rows with different superscripts differ $(P<0.05)$. seeds from IM and MT fruit among sheep and goats (Table 2). Survival of MT and MG seeds was greater after passing through cattle than through sheep or goats (Table 2). Twenty-two percent of MT seeds and $92 \%$ of MG seeds survived cattle digestion (Table 2). Sheep and goats had a lower $(\mathrm{P}<0.05)$ survival rate of mature seeds than cattle with less than $12 \%$ of the seeds surviving. Seed survival was similar between species and stage of maturity for sheep and goats.

In Trial 3, germination rates were similar among seeds that survived digestion in cattle and sheep and for seeds that had weathered on the ground (Table 3). No seeds with the exocarp intact or seeds that

Table 3. Percent $(\%)$ of seeds that germinated after undergoing digestion or weathering. Unweathered seeds were included as a control. Percent germination represents the number of seeds from each treatment that germinated.

\begin{tabular}{lc}
\hline \hline Treatment & Germination \\
\hline & $(\%)$ \\
Unweathered (with exocarp) & 0.0 \\
Dissected (without exocarp) & 26.7 \\
Weathered & 13.3 \\
Cattle MT & 0.0 \\
Cattle MG & 13.3 \\
Sheep MG & 13.3 \\
Goats MG & 0.0 \\
\hline
\end{tabular}

Germination of MT seeds for sheep and goats were not assessed because of the low survival rate.

passed through goats germinated.

\section{Experiment 2}

In $1999,96 \%$ of the mesquite fruit placed in plots had disappeared from each pasture after 1 week, regardless of the livestock species or absence of livestock (data not shown), indicating that both livestock and wildlife were eating the pods. In 2000 , some mesquite pods remained on the ground for up to 6 weeks, but few seeds remained after week 4 (Table 4 ). 
Table 4. Percent (\%) of mesquite pods remaining on the ground each week without the presence of livestock grazing in $\mathbf{2 0 0 0 .}$

\begin{tabular}{lcc}
\hline \hline Week & Remaining & SEM \\
\hline & $(\%)$ & \\
1 & 90.0 & 4.3 \\
2 & 68.8 & 5.5 \\
3 & 53.1 & 7.9 \\
4 & 38.1 & 7.2 \\
5 & 38.0 & 7.6 \\
\hline
\end{tabular}

Raccoons, skunks, deer, bobcats, and turkeys visited mesquite pod plots during the first 2 days (Table 5). Deer visited

Table 5. Percent (\%) visitation rate by different wildlife species to plots containing mesquite pods. Observations were recorded for 2 consecutive days in 2000.

\begin{tabular}{lc}
\hline \hline Species & Total Visitations \\
\hline & $(\%)$ \\
Deer & 41.9 \\
Raccoon & 26.4 \\
Bobcat & 15.7 \\
Skunk & 10.6 \\
Turkey & 5.4 \\
\hline
\end{tabular}

more frequently than any other species.

\section{Discussion}

\section{Intake and seed survival}

Intake of mesquite fruit increased with fruit maturity. Sheep and goats consumed more mesquite fruit on a body weight basis than cattle, and they ate immature fruit when offered alone. Fewer seeds survived sheep and goat digestion which suggests that sheep and goats function mainly as predators of mesquite seeds. No seeds germinated after passing through goats which suggests that goats should reduce the number of viable mesquite seeds across the landscape .

Cox et al. (1993) also reported greater seed survival following cattle digestion (28-31\%) versus sheep digestion (2-8\%). Based on our results, an animal unit (i.e., 1 cow, 4 sheep, or 5 goats), of sheep or goats would consume almost twice as many seeds as cattle $(10,000$ seeds compared to 5,000 seeds), but cattle would disperse 4 times as many seeds as sheep or goats given cattle's higher seed survival (4,500 compared to 1,200$)$. These results and others (Kramp et al. 1998) illustrate that cattle probably contribute more to seed dispersal than other livestock species.

\section{Mechanisms of seed loss}

Physiological differences among ruminant species affect the digestibility of diets that vary in composition and quality (Huston et al. 1986). Cattle have a larger reticulo-omasal orifice and omasum than sheep and goats, and larger particles, including whole mesquite seeds, are more likely to pass through cattle than sheep or goats (Hofmann 1988). Other variations in digestive physiology, such as differences in mastication times between species of livestock may also influence the ability to digest mesquite seeds. Mastication times of cattle have been observed to range from 15 to $45 \mathrm{sec}$. while that of sheep ranged from 2 to $7 \mathrm{~min}$ (Cox et al. 1993). As mastication time increases, seed damage should also increase.

\section{Germination after ingestion}

Seeds with an exocarp intact did not germinate in Trial 3 regardless of seed origin (feces, weathered, unweathered). Weathered seeds germinated when the exocarp was damaged, but germination rates were lower than the rates reported for mesquite seeds when seeds are artificially scarified (80\% germination) (Scifres and Brock 1969, 1972, Ueckert et al. 1979). Scarification naturally occurs through weathering or by digestive activities after consumption by livestock, which may explain why germination rates were the same for weathered seeds and seeds collected from cattle feces.

Bruchid larvae feed inside mesquite pods, and damage some seeds in the process (Impson and Hoffman 1998, Impson et al. 1999). Weathered seeds used in germination trials for this research showed no evidence of bruchid damage.

\section{Experiment 2}

Fruit did not remain on the ground for long periods in either year. Most fruit disappeared within 1 week in 1999 irrespective of the species of livestock present. In 2000 , most the fruit $(90 \%)$ remained after 1 week but disappeared quickly thereafter; $62 \%$ of fruit disappeared after 3 weeks. Fruit also quickly disappeared in South Texas on grazed and ungrazed plots (Owens unpubl. data), while in North Texas fruit remained on the ground for several weeks when cattle grazing was excluded (Ansley unpubl. data). Differences in fruit production could explain these differences. In 1999, few mesquite pods were produced. Fruit was collected off site and placed in each pasture and disappeared within 1 week. In 2000, when fruit production was greater, some fruit remained on the ground for 6 weeks. These data suggest that the rate of predation of mesquite fruit is dependent on overall abundance and availability of fruits.

Predation of fruits by livestock and wildlife restricts the potential for humanmanaged biological control of mesquite. Bruchid beetles are able to damage up to $90 \%$ of mesquite seeds when fruit remains on the ground for 6 months in South Africa (Hoffmann et al. 1993). When pods are quickly eaten by herbivores, bruchids are unable to colonize pods and damage most seeds (Impson et al. 1999).

Information is lacking on the combined effect of livestock and insect damage. Preliminary data indicated that bruchiddamaged seeds survived digestion but would not germinate after digestion (Kneuper and Scott 1998); however, bruchid-damaged seeds were not used in this study. It is possible that insect herbivory, when combined with livestock consumption, could further reduce the number of seeds surviving digestion. Bruchids bore a hole through the pod exocarp as the larvae escape the fruit (Watts et al. 1989). Damaged exocarps may allow rumen fluid and other digestive juices to surround the seed for additional damage and digestion.

Mesquite encroachment into grasslands and an increase in mesquite density coincide with the development of the livestock industry. Before the introduction of livestock, mesquite was restricted on most ranges because of dispersal limitations (Archer 1994). Livestock transport seeds away from existing trees, and livestock grazing opens interspaces among grass plants allowing mesquite to establish. However, mesquite also establishes in non-grazed areas with substantial grass cover (Archer 1994, Weltzin et al. 1998). Undoubtedly, the establishment of mesquite on ungrazed rangelands is impacted by seed dispersal from wildlife species. Wildlife movement is typically not limited by conventional livestock fences, thus wildlife can disperse mesquite seeds to grazed and ungrazed areas. Although different wildlife species consume and disperse mesquite seeds, livestock grazing probably accelerates the process because of greater livestock densities on most rangelands throughout Texas (Kramp et al. 1998). 


\section{Implications}

Sheep and goat grazing during the early stages of fruit development should reduce the number of viable mesquite seeds. Sheep and goats appear to act as predators to mesquite because of their consumption of immature attached to the tree (IM) fruit, and lower seed survival of digestion. Additional research should be conducted to determine if sheep and goats will consume IM fruit in the field with other forages available. In addition, it may be possible to manipulate behavioral patterns of sheep and goats to increase intake of mesquite fruits. Recent advances in behavior modification have illustrated that preferences can be formed through pairing nutrients with forages (e.g., immature fruit) (Banner et al. 2000). Supplemental nutrients (e.g., propionate, starch) could be paired with consumption of IM fruit to increase intake. If sheep and goats will consume IM mesquite fruit on rangelands, fewer mature fruits would be available for consumption by cattle and wildlife which should reduce dispersal of viable seeds.

\section{Literature Cited}

Archer, S.R. 1994. Woody plant encroachment into Southwestern grasslands and savannas: rates, patterns, and proximate causes. pp. 1368. In: Ecological Implications of Livestock Herbivory in the West. Soc. for Range Manage., Denver, Colo.

Armke, F.W. and C.B. Scott. 1999. Using cattle to disperse seeds for winter forage plants. Tex. J. Agr. Natur. Res. 12:28-38.

Banner, R.E., J. Rogosic, E.A. Burritt, and F.D. Provenza. 2000. Supplemental barley and charcoal increase intake of sagebrush by lambs. J. Range Manage. 53:415-420.

Bedunah, D.J. and RE. Sosebee. 1984. Forage response of a mesquite-buffalograss community following range rehabilitation. J. Range Manage. 37:483-487.

Cox, J.R., A. De Alba-Avila, R.W. Rice, and J.N. Cox. 1993. Biological and physical factors influencing Acacia constricta and Prosopis velutina establishment in the Sonoran Desert. J. Range Manage. 46:43-48.

Cuda, J.P. and C.J. DeLoach. 1998. Biology of Mozena obtusa (Hemiptera: Coreidae), a candidate for the biological control of Prosopis spp. (Fabaceae). Biol. Control. 13:101-110.

Gibbens, R.P., R.F. Beck, R.P. McNeely, and C.H. Herbel. 1992. Recent rates of mesquite establishment in the northern Chihuahuan Desert. J. Range Manage. 45:585-588.

Gomez, K. A. and A. A. Gomez. 1984. Statistical Procedures for Agricultural Research. pp. 187-207. John Wiley and Sons, New York, N.Y.
Heitschmidt, R. K. and S. L. Dowhower. 1991. Herbage response following control of honey mesquite within single tree lysimeters. J Range Manage. 44:144-149.

Hicks, C.R. 1993. Fundamental Concepts in the Design of Experiments. pp. 201. Saunders College Publishing, New York, N.Y.

Hoffman, J.H., F.A. C. Impson, and V.C. Moran. 1993. Competitive interactions between two bruchid species (Algarobius spp.) introduced into South Africa for biological control of mesquite weeds (Prosopis spp.). Bio. Control. 3:215-220.

Hofmann, R.R. 1988. Anatomy of the gastrointestinal tract, pp. 14-43. In: The Ruminant Animal: Digestive Physiology and Nutrition. Waveland Press, Inc., Prospect Heights.

Huston, J.E., B.S. Rector, W.C. Ellis, and M.L. Allen. 1986. Dynamics of digestion in cattle, sheep, goats, and deer. J. Anim. Sci. 62:208-215.

Impson, F.A.C. and J.H. Hoffmann. 1998. Competitive interactions between larvae of three bruchid species (Coleoptera) in mesquite seeds (Prosopis spp.) under laboratory conditions. African Entomol. 6:376-378.

Impson, F.A.C., V.C. Moran, and J.H. Hoffmann. 1999. A review of the effectiveness of seed-feeding bruchid beetles in the biological control of mesquite, Prosopis species (Fabaceae), in South Africa. African Entomol. 1:81-88.

Jacoby, P.W., C.H. Meadors, and R.J. Ansley. 1990b. Control of honey mesquite with herbicides: influence of plant height. J. Range Manage. 43:33-35.

Jacoby, P.W., R.J. Ansley, C.H. Meadors, and C.J. Cuomo. 1990a. Control of honey mesquite with herbicides: influence of stem number. J. Range Manage. 43:36-38.

Jacoby, P.W., C.H. Meadors, M.A. Foster, and FS. Hartmann. 1982. Honey mesquite control and forage response in Crane County, Texas. J. Range Manage. 35:424-426.

Kneuper, C.L. and C.B. Scott. 1998. Cattle consumption of mesquite (Prosopis glandulosa) fruit affects germination of mesquite seedlings. MIR Progress Report No. R-7 pp. 31-38. Angelo State University, San Angelo, Tex.

Kramp, B.A., R.J. Ansley, and T.R. Tunnell. 1998. Survival of mesquite seedlings emerging from cattle and wildlife feces in a semiarid grassland. Southwest. Natur. 43:300-312.

Lerner, P. and R. Peinetti. 1996. Importance of predation and germination on losses from the seed bank calden (Prosopis caldenia). J. Range Manage. 49:147-150.

NRC. 1981 Nutrient Requirements of goats: Angora, dairy, and meat goats in temperate and tropical countries. National Academy Press, Washington D.C.

NRC. 1984. Nutrient Requirements of sheep. National Academy Press, Washington D.C.

NRC. 1996. Nutrient Requirements of Beef Cattle. National Academy Press, Washington D.C.
SAS. 1994. JMP User's Guide, Version 3.1. SAS Institute Inc., North Carolina.

Scifres, C.J. and JH. Brock. 1969. Moisturetemperature interrelations in germination and early seedling development of mesquite. J. Range Manage. 22:334-337.

Scifres, C.J. and J.H. Brock. 1972. Emergence of honey mesquite seedlings relative to planting depth and soil temperature. J. Range Manage. 25:217-219.

Teague, R., R. Borchardt, R.J. Ansley, W.E. Pinchak, JR. Cox, J.K. Foy, and J. McGrann. 1997. Sustainable management strategies for mesquite rangeland: the Waggoner Kite project. Rangelands 19:4-8.

Ueckert, D. N. 1974. Influence of defoliation by the cutworm Melipotis indomita on control of honey mesquite with 2,4,5,-T in west Texas. J. Range Manage. 27:153-155.

Ueckert, D.N., L.L. Smith, and BL. Allen. 1979. Emergence and survival of honey mesquite seedlings on several soils in west Texas. J. Range Manage. 32:284-287.

Watts, J.G., G.B. Hewitt, E.W. Huddleston, H.G. Kinzer, R.J. Lavigne, D.N. Ueckert. 1989. Rangeland insects of weeds and browse, pp. 139-182. In: Rangeland Entomology. Edison Press, Denver, Colo.

Weltzin, J.F., S.R. Archer, and R.K. Heitschmidt. 1998. Defoliation and woody plant (Prosopis glandulosa) seedling regeneration: potential vs realized herbivory tolerance. Plant Ecol. 138:127-135.

Woods, J.E. 1959. Relative estimates of fox population levels. J. Wildl. Manage. 23:53-63. 


\title{
Survival of 16 alfalfa populations space planted into a grassland
}

\author{
JOHN R. HENDRICKSON AND JOHN D. BERDAHL
}

Authors are Rangeland Scientist and Plant Geneticist Northern Great Plains Research Laboratory, USDA-ARS, Box 459 Mandan, North Dakota 58554.

\begin{abstract}
Many alfalfa (Medicago spp.) cultivars have limited ability to persist under grazing and therefore, a key step in incorporating alfalfa into pastures and rangelands is choosing a grazing tolerant cultivar. In this study, we evaluated the grazing tolerance of 16 alfalfa populations representing a range of potential grazing tolerance. Entries were transplanted on a rangeland site in July 1996 at the Northern Great Plains Research Lab in Mandan, N.D., USA and mob-grazed by cattle from 1997 to 2000 . Plant survival, basal area, and stem numbers were recorded in the spring and fall of each year. At the final survival evaluation in May 2001, SCMF 3713 had the highest survival (90\%), 'Vernal' had the lowest $(23 \%)$ and 10 of the 16 entries had greater than $50 \%$ survival. A large decline in survival between September 2000 and May 2001 may be attributed to low temperatures in November and December of 2000. Entries such as 'Alfagraze', B36 and Agripro ZG9415, which were developed in warmer climates, had the largest percentage drop in survival $(43.0,48.6$, and 48.6 percentage points respectively) while SCMF 3713, 'Anik' and Alaska Syn A, developed in colder climates, had the least percentage point drops $(2.8,4.1$, and 4.1 respectively). The ability to survive over winter contributed more to the different survival rates of these alfalfa populations than did any of the measured plant variables. Producers should know the origins of grazing tolerant alfalfa cultivars and consider selecting cultivars that have been tested in their area.
\end{abstract}

Key Words: Medicago sativa ssp. falcata, mob-grazing, cold tolerance, grazing tolerance

Incorporating alfalfa into grasslands can improve the quality and quantity of available forage in the Northern Great Plains (Lorenz 1982, Heinrichs 1975) resulting in better animal performance and higher carrying capacity (Van Keuren and Matches 1988). Alfalfa can also improve nutrition later in the growing season when many of the perennial grasses experience a quality decline (Sanderson and Wedin 1989). Alfalfa has difficulty in persisting under livestock grazing in the Northern Plains (Bittman

The U.S. Department of Agriculture, Agriculture Research Service, Northern Plains Area, is an equal opportunity/affirmative action employer and all agency services are available without discrimination. The authors would like to thank G. Jensen, B. Wald, M.K. Tokach, L. Hatzenbuhler and W. Manchester for their help in data collection and J. Karn, A. Singh, P. Jefferson and 3 anonymous reviewers for their comments on an earlier version of the manuscript. Mention of product names in this document does not indicate endorsement by the USDA-ARS.

Manuscript Accepted 17 Jul. 02

\section{Resumen}

Muchos cultivares de alfalfa (Medicago spp.) tienen una capacidad limitada para persistir bajo apacentamiento, y por lo tanto, un paso clave para incorporar la alfalfa en praderas y pastizales es el elegir un cultivar tolerante al apacentamiento. En Este estudio evaluamos la tolerancia al apacentamiento de $\mathbf{1 6}$ poblaciones de alfalfa representando un rango de la tolerancia al apacentamiento. En Julio de 1996 se transplantaron las entradas de alfalfa en un sitio de pastizal del El laboratorio de Investigación Northern Great Plains en Mandan, N.D., USA y que fue apacentado por ganado de 1997 al 2000 . En primavera y otoño de cada año se registro la supervivencia de plantas, el área basal y el número de tallos. En la evaluación final de supervivencia, en Mayo de 2001, la entrada SCMF 3713 tuvo la mas alta supervivencia ( $90 \%)$, el cultivar 'Vernal' tuvo la más baja $(23 \%)$ y 10 de las 16 entradas tuvieron un porcentaje de supervivencia mayor de $50 \%$. Una gran disminución de supervivencia ocurrida entre Septiembre de 2000 y Mayo de 2001 puede ser atribuida a las bajas temperaturas de Noviembre y Diciembre de 2000. Entradas tal como 'Alfagraze', B-36 y Agripro ZG9415, las cuales fueron desarrolladas en climas cálidos, tuvieron el mayor porcentaje de caída de supervivencia $(43.0,48.6$ y $48.6 \%$ respectivamente) mientras que las entradas SCMF 3713, 'Anik' y Alaska Syn A, desarrolladas en climas fríos, tuvieron los menores porcentajes de caída de supervivencia $(2.8,4.1$ y 4.1 respectivamente). La capacidad para sobrevivir en el invierno contribuyó más en el diferencial de las tasas de supervivencia de estas poblaciones de alfalfa que cualquier otra de las variables medidas en la planta. Los productores deben conocer el origen de los cultivares de alfalfa tolerantes al apacentamiento y considerarlo en la selección de los cultivares que van a ser probados en su área.

and McCartney 1994). A first step in incorporating alfalfa into rangelands is to determine cultivars that can withstand livestock grazing pressure. Cultivars with a high proportion of Medicago sativa ssp. falcata parentage have been demonstrated to improve the persistence of alfalfa under grazing (Berdahl et al. 1989, Bittman and McCartney 1994).

The ability to persist under livestock grazing has been suggested as an important selection criteria in development of alfalfa cultivars (Brummer and Moore 2000). Selection of surviving plants under heavy, continuous grazing has been shown to improve the grazing tolerance of alfalfa (Smith et al. 1989, Smith and Bouton 1993). Much of this work has been done in monoculture situations where competition is intra-specific rather than inter-specific. Long-term trials where cultivars are grown in competition 
with grasses may be necessary to identify superior cultivars for use in pastures and rangelands (Berdahl et al. 1989, Bittman et al. 1991).

Morphological traits have been shown to improve grazing resistance in grasses (Briske 1991). Understanding plant traits that may influence grazing persistence in alfalfa would be beneficial to forage breeders and managers alike. Traits such as prostrate growth, thin stems and low yield (Brummer and Bouton 1991) as well as the ability to produce new plants from root propagules (Heinrichs 1963, Berdahl et al. 1986) have been associated with grazing tolerant alfalfas. Alfagraze, however, has shown excellent grazing tolerance (Smith et al. 1989, Smith and Bouton 1993, Brummer and Moore 2000) and yet has high yield, intermediate decumbency, and many, thick stems (Brummer and Bouton 1991).

Fall dormancy is determined by measuring the amount of regrowth that occurs 25 to 30 days after an appropriate final clipping date in the fall (Teuber et al. 1998). There is a close association between winterhardiness of cultivars and fall dormancy (McKenzie et al. 1988). Because of this, fall dormancy is often used as a means of determining the suitability of a cultivar for a climatic regime (Melton et al. 1988).

The first step in successfully incorporating alfalfa into rangelands in the Northern Great Plains is to choose an appropriate cultivar. Our objective in this study was to evaluate the survival of 16 different cultivars and strains of alfalfa that were grown in association with grass and grazed.

\section{Material and Methods}

This study was conducted at the Northern Great Plains Research Laboratory located approximately $6 \mathrm{~km}$ south of Mandan, N.D. $\left(46^{\circ} 46^{\prime} \mathrm{N} 100^{\circ} 50^{\prime}\right.$ W). Sixteen cultivars and strains of alfalfa were transplanted into a native rangeland in July 1996. Alfalfa plants were started from seed in cone-tainers (Stewe and Sons, Corvallis, Ore.) and were 3 months old when transplanted into the site. The rangeland had not been grazed for at least 15 years prior to the study and the vegetation was dominated by smooth bromegrass (Bromus inermus Leyss.). Native species present included blue grama [Bouteloua gracilis (H.B.K.) Lag. ex. Steud.], little bluestem [Schizachyrium scoparium (Michx.) Nash], praire coneflower [Ratibida columnifera (Nutt.) Woot.\& Standl.], cudweed sagewort (Artemisia

Table 1. Information about alfalfa entries in the grazing study. Comments include use and origin. Dormancy indicates the estimated fall dormancy rating.

\begin{tabular}{|c|c|c|}
\hline Entry & Comments & Dormancy \\
\hline Vernal & $\begin{array}{l}\text { Standard Hay-type Cultivar, Medicago sativa subsp. x } \\
\text { varia, University of Wisconsin }\end{array}$ & 2 \\
\hline Ladak 65 & $\begin{array}{l}\text { Hay and Pasture type, } M \text {. sativa subsp. x varia, Montana } \\
\text { State University }\end{array}$ & 1 \\
\hline Travios & Grazing type, $M$. sativa subsp. $\mathrm{x}$ varia, South Dakota State University & 1 \\
\hline Rangelander & $\begin{array}{l}\text { Grazing type, } M \text {. sativa subsp. x varia, Agriculture and Agri-Food } \\
\text { Canada, Swift Current, Saskatchewan }\end{array}$ & 1 \\
\hline Spredor 3 & Grazing type, $M$. sativa subsp. x varia Northup-King & 1 \\
\hline Alfagraze & $\begin{array}{l}\text { Grazing type, M. sativa subsp. } \mathrm{x} \text { varia Developed by } \\
\text { University of Georgia, Distributed by America's Alfalfa }\end{array}$ & 2 \\
\hline ZG9415 & $\begin{array}{l}\text { Grazing type, } M \text {. sativa subsp. x varia, Experimental, } \\
\text { Developed under grazing in Missouri, AgriPro Seeds }\end{array}$ & $\begin{array}{l}2 \\
1\end{array}$ \\
\hline Anik & $\begin{array}{l}\text { Grazing type, } M \text {. sativa subsp. falcata, Agriculture and } \\
\text { Agri-Food Canada, Beaverlodge, Alberta }\end{array}$ & \\
\hline Mandan 3851 & $\begin{array}{l}\text { Grazing type, } M \text {. sativa subsp. x varia, Experimental, USDA-ARS } \\
\text { Mandan, N.D. }\end{array}$ & 1 \\
\hline $\begin{array}{l}\text { Mandan } \\
\text { Grasshopper } \\
\text { Preference }\end{array}$ & $\begin{array}{l}\text { Collected from a grasshopper preference study, } \text { M. sativa } \\
\text { subsp. x varia, Experimental, USDA-ARS, Mandan, N.D. }\end{array}$ & 1 \\
\hline SCMF3713 & $\begin{array}{l}\text { Grazing type, } M \text {. sativa subsp. falcata, Experimental, Agriculture } \\
\text { and Agri-Food Canada, Swift Current, Saskatchewan }\end{array}$ & 1 \\
\hline Alaska Syn A & $\begin{array}{l}\text { Hay and pasture type, } M \text {. sativa subsp. x varia, Institute of } \\
\text { Agriculture, University of Alaska and USDA-ARS, Palmer, Alask.a }\end{array}$ & 1 \\
\hline B-36 & $\begin{array}{l}\text { Experimental, Decumbent Growth, } M \text {. sativa subsp. x varia, } \\
\text { Collected in Turkey, USDA-ARS Beltsville, Maryland }\end{array}$ & $\begin{array}{l}3 \\
1\end{array}$ \\
\hline $\mathrm{C}-27$ & $\begin{array}{l}\text { Mixture of } 2 \mathrm{X} \text { and } 4 \mathrm{X} M \text {. sativa subsp. falcata, USDA-ARS } \\
\text { and Colorado Agricultural Experiment Station }\end{array}$ & \\
\hline $\mathrm{C}-31$ & $\begin{array}{l}\text { M. sativa subsp. } \mathrm{x} \text { varia, USDA-ARS and Colorado } \\
\text { Agricultural Experiment Station }\end{array}$ & 1 \\
\hline Pioneer 5151 & $\begin{array}{l}\text { Hay and Pasture, } M \text {. sativa subsp. x varia, } \\
\text { Pioneer Hi-Bred International }\end{array}$ & 1 \\
\hline
\end{tabular}

ludoviciana Nutt.), and fringed sagebrush (Artemisia frigida Willd). As the study progressed, Kentucky bluegrass (Poa pratensis L.) began to invade the site.

Fifteen of the entries were selected based on their grazing tolerance and Vernal was used as a check. Entries are described in Table 1. Eight blocks (reps) contained randomly assigned plots of each entry. Each plot contained 9 plants of the same entry space planted on $0.9 \mathrm{~m}$ centers in a $3 \times 3$ matrix. There was a total of 128 plots containing 1,152 plants.

Grazing was conducted using the mob grazing technique (Bittman and McCartney 1994). Four head of yearling steers were placed on the study site and the alfalfa was grazed to an average height of $5 \mathrm{~cm}$. When average regrowth, based on a random subset of all entries, reached approximately $15 \mathrm{~cm}$ or more, grazing was started again. The last grazing event was usually in mid to late September prior to the first frost. There were 3 grazing events in 1997, 5 in 1998, 5 in 1999, and 4 in
2000. In 1997, initial grazing was delayed until 24 July to allow establishment of plants that had been damaged by grasshopper herbivory in 1996. Only 55 plants out of a total of 1,152 had severe damage from grasshoppers and these were replaced in early spring 1997 . After 1997, the first grazing event was started when alfalfa reached the bud stage.

Plant survival was evaluated in May after some regrowth had occurred and in September after the last grazing event in each year. The final survival count was done in May 2001. Each plot was visually surveyed to determine the number of live plants. Plants with some green material remaining were considered as living. Survival was evaluated as the proportion of living plants divided by 9 (the number of original transplants) in each plot. As the study progressed, many entries produced new plants, mainly from horizontal rootstocks. These new plants that emerged in the vicinity of the original plant were counted separately; however, if the origi- 
nal plant had died but there was a new plant in the same vicinity, the plant was considered as alive.

Basal area and stem numbers were determined in the spring and fall of each year except for 1997 . There were relatively minor differences in stem numbers and basal area between entries at the beginning of the study, so data are presented as absolute values. Basal area was measured by using a nylon string to measure plant circumference and this value was converted into basal area with the formula:

$$
\frac{\text { (Basal Circumference) }^{2}}{4 \pi}
$$

Total basal area was determined on each original and daughter plant separately and then summed to get total basal area. Parental basal area was determined on the original plants only. Stem numbers were also determined on parental and total plants.

Temperature data were collected year round from a weather station located 2.4 $\mathrm{km}$ from the study location. Precipitation data from April through October were collected from the same station. Precipitation data from November through March were collected from a National Weather Service station located $4 \mathrm{~km}$ from the study site. This was also the reference site for the long-term (1913-2000) weather data.

Precipitation data were collected for the last 6 months of 1996, all of 1997, 1998, 1999, and 2000 and for the first 5 months of 2001 . Only 1997 , which had $73 \%$ of the long-term average precipitation and the first 5 months of 2001 which had $94 \%$ of the long-term average precipitation were drier than normal. Precipitation during the last 6 months of 1996, and all of 1998, 1999 , and 2000 was $144,127,136$, and $121 \%$ of the long-term average, respectively. Yearly average maximum and minimum temperatures were generally within $1.5^{\circ} \mathrm{C}$ of the long-term average. Exceptions were maximum temperatures during the last 6 months in 1996 which averaged $4.7^{\circ} \mathrm{C}$ cooler than the long-term average, the minimum for 1998 which averaged $3^{\circ} \mathrm{C}$ warmer than long-term average and the minimum for the first 5 months in 2001 which averaged $2^{\circ} \mathrm{C}$ warmer than the long-term average. Monthly maximum and minimum departures from the long-term average are shown in Figure 1. Maximum tempera- tures for most of the growing season in 1999 were cooler than the long-term average but winter temperatures were warmer than the long-term average. In November and December of 2000, maximum and minimum temperatures were cooler than the long-term average as was the maximum and minimum for February 2001.

Survivorship data were transformed by taking the arc sin of the number of surviving plants in each plot divided by 9 (the number of original plants) and then analyzed using PROC Mixed procedure in SAS (Littell et al. 1996). Entry and year were considered the fixed effects and replicate considered as a random effect. Mean survival data presented for each entry are expressed in non-transformed values (Table 2). Partial correlation coefficients were calculated using the Manova procedure in SAS (1990). Average number of daughter plants, stem numbers and parental, and total basal area for September 2000 were analyzed using Proc Mixed (Littell et al.1996) with the same terms as the survivorship data. Means were separated using the Tukey-Kramer adjusted means procedure at $\mathrm{P}<0.05$.
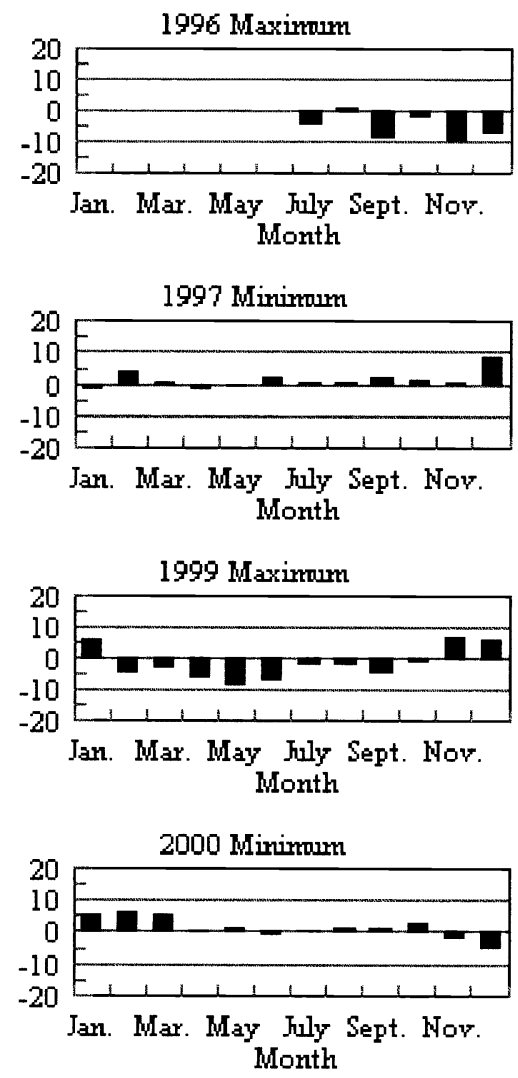
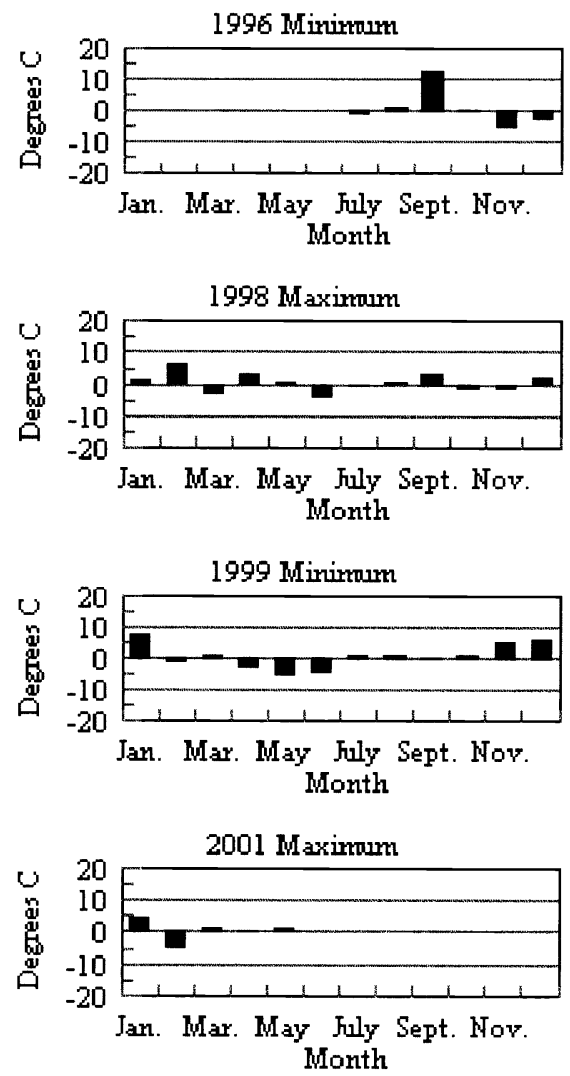
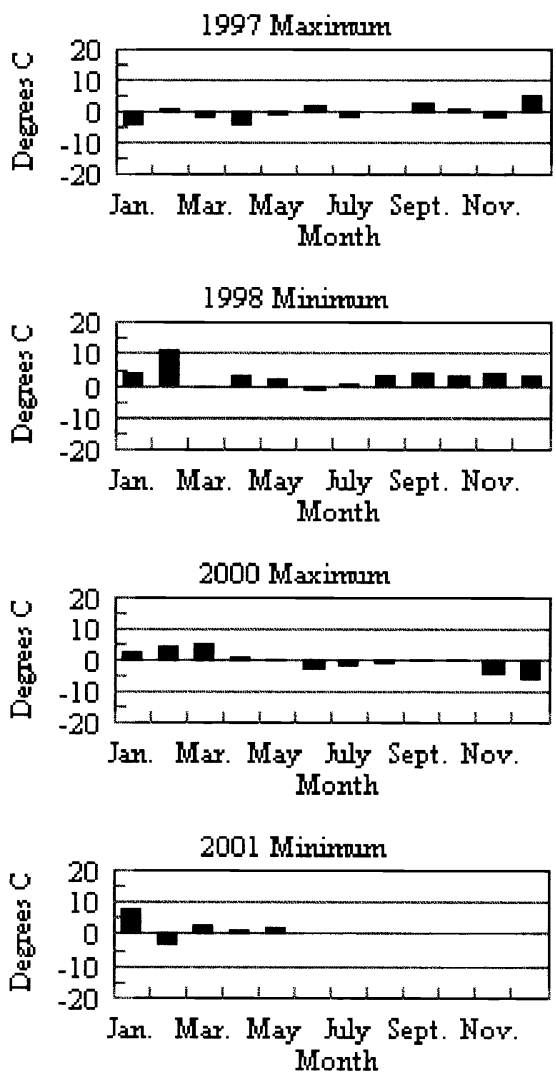

Fig. 1. Monthly departures from long-term average (1913 to 2000) for maximum and minimum temperatures from July 1996 to May 2001 . Y axis indicates departure from long-term average in degrees $C$. 
Table 2. Percent survival in September 2000 and May 2001, decline in percent survival between September 2000 and May 2001 , total basal area in May 2000 and September 2000 and stem numbers in May 2000 of selected alfalfa cultivars. Decline in percent survival is the number of percentage points survival declined between September 2000 and May 2001 . Significant differences between means within a column are noted by different letters.

\begin{tabular}{|c|c|c|c|c|c|c|}
\hline Entry & $\begin{array}{c}\text { September } \\
2000 \\
\text { Survival }\end{array}$ & $\begin{array}{c}\text { May } \\
2001 \\
\text { Survival }\end{array}$ & $\begin{array}{c}\text { Decline in } \\
\text { percentage } \\
\text { points }\end{array}$ & $\begin{array}{c}\text { May } \\
2000 \\
\text { Total Basal Area }\end{array}$ & $\begin{array}{c}\text { September } \\
2000 \\
\text { Total Basal Area }\end{array}$ & $\begin{array}{c}\text { May } \\
2000 \\
\text { Stem } \\
\text { numbers }\end{array}$ \\
\hline & $(\%)$ & $(\%)$ & & $\left(\mathrm{cm}^{2}\right)$ & $\left(\mathrm{cm}^{2}\right)$ & $\left(\right.$ Plant $\left.^{-1}\right)$ \\
\hline Vernal & $45.8 \mathrm{~b}$ & $23.6 \mathrm{~d}$ & 22.2 & 96.1 & $182.9 \mathrm{ab}$ & $12.4 \mathrm{~b}$ \\
\hline Ladak 65 & $72.2 \mathrm{ab}$ & $45.8 \mathrm{bcd}$ & 26.4 & 108.5 & $193.1 \mathrm{ab}$ & $21.2 \mathrm{ab}$ \\
\hline Travois & $85.8 \mathrm{ab}$ & $73.6 \mathrm{abc}$ & 12.2 & 115.0 & $250.1 \mathrm{a}$ & $26.6 \mathrm{a}$ \\
\hline Rangelander & $70.3 \mathrm{ab}$ & 56.9 abcd & 13.4 & 93.4 & $199.9 \mathrm{ab}$ & $20.3 \mathrm{ab}$ \\
\hline Spredor 3 & $84.7 \mathrm{a}$ & $58.3 \mathrm{abcd}$ & 26.4 & 88.7 & $185.0 \mathrm{ab}$ & $16.5 \mathrm{ab}$ \\
\hline Alfagraze & $69.4 \mathrm{ab}$ & $26.4 \mathrm{~d}$ & 43.0 & 83.2 & $170.6 \mathrm{ab}$ & $18.7 \mathrm{ab}$ \\
\hline ZG9415 & $75.0 \mathrm{ab}$ & $26.4 \mathrm{~d}$ & 48.6 & 87.6 & $183.1 \mathrm{ab}$ & $18.6 \mathrm{ab}$ \\
\hline Anik & $81.9 \mathrm{ab}$ & $77.8 \mathrm{ab}$ & 4.1 & 87.2 & $131.9 \mathrm{~b}$ & $21.2 \mathrm{ab}$ \\
\hline Mandan 3851 & $86.1 \mathrm{a}$ & $73.6 \mathrm{abc}$ & 12.5 & 111.0 & $184.2 \mathrm{ab}$ & $23.0 \mathrm{ab}$ \\
\hline Mandan Grasshopper Preference & $63.9 \mathrm{ab}$ & $44.4 \mathrm{bcd}$ & 19.5 & 122.3 & $222.2 \mathrm{ab}$ & $21.0 \mathrm{ab}$ \\
\hline SCMF 3713 & $93.1 \mathrm{a}$ & $90.3 \mathrm{a}$ & 2.8 & 129.8 & $217.4 \mathrm{ab}$ & $25.6 \mathrm{a}$ \\
\hline Alaska Syn A & $83.3 \mathrm{ab}$ & $79.2 \mathrm{ab}$ & 4.1 & 146.8 & $207.5 \mathrm{ab}$ & $20.9 \mathrm{ab}$ \\
\hline B-36 & $86.1 \mathrm{a}$ & $37.5 \mathrm{~cd}$ & 48.6 & 142.0 & $167.4 \mathrm{ab}$ & $18.9 \mathrm{ab}$ \\
\hline C-27 & $61.1 \mathrm{ab}$ & $55.6 \mathrm{abcd}$ & 5.5 & 112.3 & $205.8 \mathrm{ab}$ & $18.3 \mathrm{ab}$ \\
\hline $\mathrm{C}-31$ & $84.7 \mathrm{ab}$ & $77.8 \mathrm{abc}$ & 6.9 & 139.8 & $237.7 \mathrm{ab}$ & $22.2 \mathrm{ab}$ \\
\hline Pioneer 5151 & $80.6 \mathrm{ab}$ & $51.4 \mathrm{bcd}$ & 29.2 & 117.7 & $252.2 \mathrm{a}$ & $25.2 \mathrm{a}$ \\
\hline
\end{tabular}

\section{Results}

Survival declined sharply from September 2000 to May 2001 (Fig. 2). Survival for all entries declined during this period (Table 2), but entries varied in the amount of decline resulting a time by entry interaction. The decline in survival ranged from 48.6 percentage points for ZG9415 and B-36 to 2.8 percentage points for SCMF 3713. Five of the entries had a decline of less than 10 percentage points, 4 of the entries had a decline of 10-20 percentage points, 4 entries had declines of 20-30 percentage points and 3 entries had a decline of over 40 percentage points between September 2000 and May 2001.

Survival of the 16 alfalfa entries in May 2001 ranged from $23 \%$ for Vernal to $90 \%$ for SCMF 3713. Ten of the 16 had survival greater than $50 \%$ (Table 2). Survival of SCMF 3713 was significantly higher ( $P$ $<0.05)$ than Vernal, 'Ladak 65', Alfagraze, ZG9415, Mandan Grasshopper Preference, Beltsville B-36 and 'Pioneer
5151'. Alaska Syn A had significantly higher $(P<0.05)$ survival than Beltsville B-36, ZG9415, Alfagraze and Vernal. Vernal, ZG9415 and Alfagraze had significantly lower $(\mathrm{P}<0.05)$ survival than 'Travois', Anik, Mandan 3851 or C-31 from Colorado.

Total basal area for live plants in May 2000 ranged from a low of $83.24 \mathrm{~cm}^{2}$ for Alfagraze to a high of $146.79 \mathrm{~cm}^{2}$ for Alaska Syn A (Table 2). There was no significant difference among entries in the May 2000 total basal area. Total basal area in September 2000 ranged from $132 \mathrm{~cm}^{2}$ for Anik to $252 \mathrm{~cm}^{2}$ for Pioneer 5151 and there were significant differences $(\mathrm{P}<$ 0.05 ) among entries. Total basal area of Anik was less $(\mathrm{P}<0.05)$ than total basal area of Travois and Pioneer 5151 (Table 2). Total basal area declined during 1997 and 1998 growing seasons and then increased in the 1999 and 2000 growing seasons (data not shown).

Spring 2000 stem numbers ranged from an average of 12.4 for Vernal to 26.6 for
Travois. Vernal had significantly $(\mathrm{P}<$ 0.05) lower stem numbers than did SCMF 3713 and Travois (Table 2). Stem numbers increased during every growing season except for 1997 (data not shown).

All of the plant traits measured had significant but relatively low correlation coefficients with the May 2001 survival (Table 3). May 2001 survival was most strongly correlated $(r=0.46)$ with total basal area in September 2000 , followed by spring stem numbers $(r=0.41)$ and total basal area in the spring of $2000(r=0.35)$. Average number of daughter plants in the spring and fall and fall stem numbers had the lowest correlations with May 2001 survival ( $r$ $=0.25,0.23$ and 0.26 , respectively)

\section{Discussion}

Survival of alfalfa entries in this study exhibited a time by entry interaction, primarily driven by a sharp decline in survival for some entries between September 


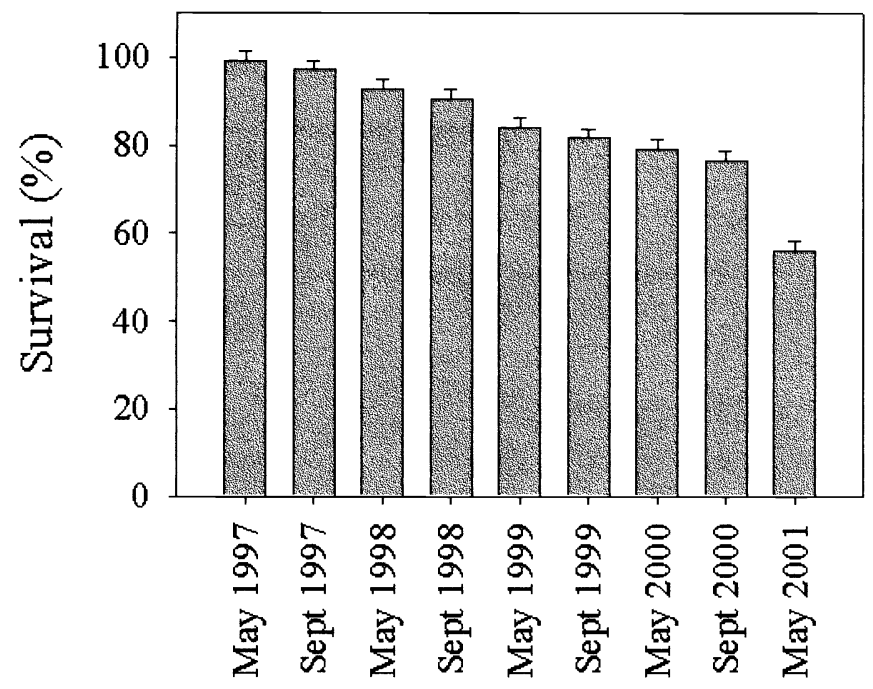

Time

Fig. 2. Average percent survival pooled over entries from May 1997 to May 2001.

2000 and May 2001. Colder than average temperatures in November and December of 2000 as well as February 2001 may have precipitated this decline. There were also several days in mid-April where the temperatures did not exceed $0^{\circ} \mathrm{C}$. The only other comparative period during the study was the winter directly following establishment (November 1996 to April 1997). However during that period, record snowfall, as well as a lack of grazing pressure, may have reduced the impact of the cold temperatures.

While the survival of all entries declined from September 2000 to May 2001, the most dramatic declines were for entries from warmer regions with higher fall dormancy scores. Alfagraze, B-36 and ZG9415 were developed in Georgia, Maryland and Missouri, respectively, and all had declines of over 40 percentage points. These entries all had a fall dormancy score of 2 or higher. Fall dormancy has been identified as a good predictor of alfalfa survival in Minnesota (Sheaffer et al. 1997), and mortality of non-dormant alfalfa is less when the plants have traits associated with fall dormancy such as generally slower growth and larger roots (Hotchkiss et al. 1996). In our study, the small number of entries with dormancy ratings greater than 1 make it difficult to reach any conclusions regarding fall dormancy and survival. However, there were differences in survival among entries with a fall dormancy rating of 1 which may suggest other factors besides fall dormancy affect winter survival. survival. shown to have a higher proportion of determinate taproots than field grown plants (Lamb et al. 2000). Determinate taproots split into 2 or more relatively equal size roots (Lamb et al. 2000). The effect of this on alfalfa survival is unknown and our results may differ from a direct seeded stand.

Traits related to plant size had the strongest positive correlation with survival. Plants that had a larger total basal area in September 2000 or more stems in May 2000 were most likely to survive. The correlations with parental basal area were less strong than those with total basal area (Table 3). Brummer and Bouton (1991) reported that broad crowns were not associated with grazing tolerance in the germplasm they examined, which included Travois and Alfagraze; however, other reports have indicated that broad crown development from rhizome proliferation was associated with survival of alfalfa when grazed (Berdahl et al. 1989). In our study, parental basal area was less strongly correlated with survival than total basal area, which included new plants in the vicinity of the original parental plants. Still, definitive conclusions are difficult because of the wide range in geographic origin of the entries.

It has been suggested that the ability to produce new shoots from horizontal rootstalks may be an important survival mechanism for alfalfa in rangelands (Heinrichs 1963, Berdahl et al. 1986, 1989). For the entries we considered, however, average number of new plants in 2000 was the trait with the lowest correlation with survival. Still, these daughter plants would have contributed to total basal area, which was more strongly correlated with survival.

Plants with more stems in May 2000 were more likely to survive until the following year $(r=0.41)$ but stem numbers in September 2000 were less strongly correlated with survival $(r=0.26)$. Stem numbers increased for all species except Anik between spring and fall (data not

Table 3. Correlation coefficients of various selected plant traits recorded in 2000 with May 2001

\begin{tabular}{lll}
\hline \hline Trait & r value & P value \\
\hline Average number of daughter plants per plot in Spring 2000 & 0.25 & 0.0074 \\
Average number of daughter plants per plot in Fall 2000 & 0.23 & 0.0123 \\
Total Basal Area in Spring 2000 & 0.35 & 0.0002 \\
Parental Basal Area in Spring 2000 & 0.28 & 0.0034 \\
Total Basal Area in Fall 2000 & 0.46 & 0.0001 \\
Parental Basal Area in Fall 2000 & 0.33 & 0.0004 \\
Number of Stems in Spring 2000 & 0.41 & 0.0001 \\
Number of Stems in Fall 2000 & 0.26 & 0.0060 \\
\hline
\end{tabular}


shown) but an increase in stem numbers did not appear to increase survival. For example, stem numbers for Vernal in September 2000 were $170 \%$ greater than in May 2000, but this cultivar had the lowest survival. On the other hand, SCMF 3713 , which had the highest survival, only increased stem numbers over the growing season by $30 \%$. Brummer and Bouton (1991) suggested the high number of crown buds produced by Alfagraze might aid in its persistence. This may indicate why stem numbers in the spring had a stronger correlation with survival than did stem numbers in the fall. Since axillary buds are the source of new shoots in other perennial plants such as grasses (Murphy and Briske 1992), a large population of buds that survive the winter may result in higher stem numbers in the spring.

\section{Implications:}

This study illustrates the need for producers to emphasize not only grazing tolerance but also climatic adaptability when they chose cultivars. It is important to recognize that germplasm with a wide range in genetic background and geographic origin was studied and that selected plant traits generally had low correlations $(r<$ $0.5)$ with survival. Within each measured trait, there were some entries that survived well despite not having a large basal area or number of stems. While the ability to withstand grazing is crucial for grazing tolerant alfalfa cultivars to be successful, in many colder areas the ability to withstand the climatic extremes is also important. Producers should choose cultivars that are not only grazing tolerant but that can withstand the climatic regime in their region. Breeding programs should include adaptation to climate as well as grazing tolerance in their selection criteria.

\section{Literature Cited}

Berdahl, J.D., A.C. Wilton, and A.B. Frank. 1989. Survival and agronomic performance of 25 alfalfa cultivars and strains interseeded into rangeland. J. of Range Manage. 42:312-316.

Berdahl, J.D., A.C. Wilton, R.J. Lorenz, and A.B. Frank. 1986. Alfalfa survival and vigor in rangeland grazed by sheep. J. of Range Manage. 39:59-62.

Bittman, S. and D.H. McCartney. 1994. Evaluating alfalfa cultivars and germplasms for pastures using the mob-grazing technique. Can. J. Plant Sci. 74:109-114.
Bittman, S., J. Waddington, and D.H. McCartney. 1991. Performance of alfalfa strains grown in mixture with smooth bromegrass as affected by management. Can. J. Plant Sci. 71:1029-1037.

Briske, D.D. 1991. Developmental morphology and physiology of grasses. In: Heitschmidt, R. K. and Stuth, J. W. (eds.) Grazing Management: An ecological perspective. Portland, Oregon: Timber Press; 1991: 85-108.

Brummer, E.C. and J.H. Bouton. 1991. Plant traits associated with grazing-tolerant alfalfa. Agron. J. 83:996-1000.

Brummer, E.C. and K.J. Moore. 2000. Persistence of perennial cool-season grass and legume cultivars under continuous grazing by beef cattle. Agron. J. 96:466--471.

Heinrichs, D.H. 1963. Creeping alfalfas. Adv. Agron. 15:317-337.

Heinrichs, D.H. 1975. Potentials of legumes for rangelands. p. 50-61 In: Campbell, R. S. and Herbel, C. H. (Eds). Range Symposium Series. v. No. 1. Improved Range Plants. Soc. Range Manage. ; Denver, Colo.

Hotchkiss, J.R., S.E. Smith, and W.B. Miller. 1996. Persistence and single-plant productivity in nondormant alfalfa. Crop Sci. 36:336-340.

Lamb, J.F.S., L.D. Johnson, D.K. Barnes, and J.J. Marques-Ortiz. 2000. A method to characterize root morphology traits in alfalfa. Can. J. Plt. Sci. 80: 97-104.

Littell, R.C., G.A. Miliken, W.W. Stroup, and R.D. Wolfinger. 1996. SAS ${ }^{\circ}$ System for Mixed Models, SAS Institute Inc. Cary, N.C.

Lorenz, R.J. 1982. Alfalfa in Western grazing management systems. p. 1-3. In: Alfalfa for dryland grazing. USDA-ARS Agr. Info. Bull.. No. 444, U.S. Government Printing Office, Washington D.C

McKenzie, J.S., R. Paquin, and S.H. Duke. 1988. Cold and heat tolerance. p. 259-302. In: Alfalfa and Alfalfa Improvement. A.A. Hanson, D.K. Barnes, and R.R. Hill Jr. (Eds). Agronomy Monograph no. 29. ASA-CSSASSSA, Madison, Wisc.

Melton, B., J. B. Moutray, and J. H. Bouton. 1988. Geographic adaptation and cultivar selection. p. 595-620. In: Alfalfa and Alfalfa Improvement. A.A. Hanson, D.K. Barnes, and R.R. Hill Jr. (Eds) Agronomy Monograph no. 29. ASA-CSSA-SSSA, Madison, Wisc.

Murphy, J.S. and D.D. Briske. 1992. Regulation of tillering by apical dominance: Chronology, interpretive value, and current perspectives. J. Range Manage. 45:419-429.

Sanderson, M.A. and W.F. Wedin. 1989. Phenological stage and herbage quality relationships in temperate grasses and legumes. Agron. J. 81: 864-869.

SAS. 1990. SAS/STAT ${ }^{\circledR}$ User's Guide, Version 6, Fourth Edition, SAS Institute Inc, Cary, N.C.
Sheaffer, C.C., J. Grimsbo Jewett, D.K. Barnes, W.E. Lueschen, D.R. Swanson, and R. Matthison, 1997. Alfalfa persistence under infrequent cutting. J. Prod. Agr. 10:558-561.

Smith, S.R. Jr. and J.H.Bouton. 1993. Selection within alfalfa cultivars for persistence under continuous stocking. Crop Sci. 33:1321-1328.

Smith S.R. Jr., J.H. Bouton, and C.S Hoveland. 1989. Alfalfa persistence and regrowth potential under continuous stocking. Agron. J. 81:1321-1328.

Teuber, L.R., K.L. Taggard, L.K. Gibbs, M.H. McCaslin, M.A. Peterson, and D.K. Barnes. 1998. Fall Dormancy. Section A-1, p. 1-2. In C.C. Fox, R.Berberet, F.A. Gray, C.R.Grau, D.L. Jessen, and M.A. Peterson (ed.) Standard tests to characterize alfalfa cultivars, $3^{\text {rd }}$ edition. North American Alfalfa Improvement Conference. http://www.NAAIC.ORG/stdtests/Dormancy 2 .html. Accessed 27 February, 2002.

Van Keuren, R. W. and A.G. Matches. 1988. Pasture production and utilization. p. 515-538. In: Alfalfa and Alfalfa Improvement. A.A. Hanson, D.K. Barnes, and R.R. Hill Jr. (Eds) Agron. Mono. no. 29. ASA-CSSA-SSSA, Madison, Wisc. 


\title{
Toxicity and development of tolerance in cattle to timber milkvetch
}

\author{
W. MAJAK, L. STROESSER, T. LYSYK, AND J.W. HALL
}

Authors are Toxic Plant Biochemist and Range Manager, Agriculture and Agri-Food Canada (AAFC) Range Research Unit, 3015 Ord Road, Kamloops, B.C. V2B 8A9, Entomologist, AAFC Research Centre, Lethbridge, AB, TIJ 4BI and Biostatistician, Pacific Agri-Food Research Centre, Summerland, B.C. V0H 1Z0.

\begin{abstract}
Timber milkvetch (TMV, Astragalus miser Dougl. ex Hook var. serotinus) is widely distributed on rangelands in the southern interior of British Columbia, Canada. It synthesizes large quantities of miserotoxin, a glycoside that is toxic to cattle. Six grazing studies were conducted at Sixtyone Creek on the Cariboo Plateau during 1993 to 2000 to determine which class of livestock was most susceptible to TMV, to record clinical signs of poisoning under range conditions, and to determine the efficacy of protein supplements for the prevention of TMV poisoning. In vitro rates of TMV detoxification in rumen fluid were determined concurrently. Incidents of early, acute and chronic poisoning were documented using a total of 143 cows over the 6 year study. Older cows (more than 3-years old) and yearling heifers were less susceptible to TMV than lactating first-calf heifers, which showed acute signs of poisoning. A chronic syndrome was sometimes seen in second-calf heifers, especially during exertion. Heifers not previously exposed to TMV, such as those that were obtained from the prairie region of Alberta, were also more susceptible than cattle originating in B.C. with a known history of exposure to TMV. Each year, Hereford cows were divided into 2 groups, one of which received free-choice protein supplements in a molasses block, the other did not receive supplement and served as a control group during the 6-week grazing trial. The control group yielded 25 cases of TMV poisoning during the 6-year study, compared with 2 for the supplement group. However, the supplement increased rates of TMV detoxification $(>50 \%)$ in only 1 of the 5 years of testing. Native cattle yielded higher rates of TMV detoxification (> 25\%) in 2 of the 5 years than introduced cattle. The innate capacity to transfer rumen microbial activity between cattle in close proximity and the natural enrichment of rumen microbial populations could elevate rates of detoxification regardless of supplement or origin.
\end{abstract}

Key Words: poisonous plants, Astragalus miser var. serotinus, detoxification, protein supplements.

The Interior Douglas Fir (Pseudotsuga menziesii (Mirb.) Franco) zone is the most important forest zone for cattle grazing

\footnotetext{
The authors would like to thank Ruth McDiarmid and summer students Cindy Hunter, Monica Durigon, Jessica Herauf and Barbara Wheatley for conducting in vitro assays and lab analyses; Keith Ogilvie, Greg and Ross Syme for care and handling of livestock; and the B.C. Ministry of Forests, 100 Mile District for their support. The study was partially funded by the Beef Cattle Industry Development Fund (Projects \#4, \#82 and \#125).

Manuscript accepted 8 Aug. 01.
}

Resumen

“Timber milkvetch" (TMV, Astragalus miser Dougl. ex Hook var. serotinus) esta ampliamente distribuida en los pastizales del sur de Columbia Británica, Canadá. Esta especies sintetiza grandes cantidades de miserotoxina, un a glicóosido que es tóxico para el ganado. De 1993 a 2000 se realizaron 6 estudios de apacentamiento en el Arroyo Sixtyone en la Meseta Cariboo para determinar que clase de ganado fue mas susceptible a TMV, registrar los signos clínicos de envenenamiento bajo condiciones del pastizal y determinar la eficacia de suplementos proteicos para prevenir el envenenamiento por TMV. Las tasas de detoxificación in vitro de TMV en el fluido ruminal se determinaron concurrentemente. Incidentes de intoxicación inicial, aguda y crónica se documentaron usando un total de 143 vacas en los 6 años de estudio. Las vacas viejas (mas de 3 años de edad )y las vaquillas de un año fueron menos susceptibles al TMV que las vacas lactantes de primer parto, las cuales mostraron signos agudos de intoxicación. A veces se observó un síndrome crónico envacas de segundo parto, especialmente durante el parto. Las vaquillas no expuestas previamente al TMV, tales como las que fueron obtenidas de la región de praderas de Alberta, fueron también mas susceptibles que el ganado originario de Columbia Británica con una historia conocida de exposición al TMV. Cada año las vacas Herford se dividieron en 2 grupos, uno de los cuales recibió suplementos proteicos a libre acceso en bloques de melaza, el otro grupo no fue suplementado y sirvió como control durante el ensayo de apacentamiento de 6 semanas. El grupo control produjo 25 casos de intoxicación por TMV durante el periodo de estudio de 6 años, comparado con 2 casos del grupo suplementado. Sin embargo, el suplemento incrementó las tasas de desintoxicación de TMV (>50\%) en solo 1 de 5 años de prueba. El ganado nativo produjo tasas más altas de desintoxicación (>25\%) en 2 de los 5 años que las del ganado introducido. La capacidad innata para transferir la actividad ruminal microbiana entre el ganado en una proximidad cercana y el enriquecimiento natural de las poblaciones microbianas del rumen pueden elevar las tasas de desintoxicación, sin importar el suplemento o el origen.

in southern British Columbia (Wikeem et al. 1993). Timber milkvetch (TMV), also known as Columbia milkvetch (Astragalus miser Dougl. ex Hook. var. serotinus), is a legume that can be abundant in this zone, especially in lodgepole pine (Pinus contorta Dougl. ex Loudon) forests on the Cariboo Plateau. The crude protein content of TMV is relatively high (Majak et al. 1996) but TMV also synthesizes large quantities of 
miserotoxin, a glycoside of 3-nitropropanol $(\mathrm{NPOH})$ that causes acute and chronic poisoning in ruminants (Maricle et al. 1996). The glycoside is rapidly hydrolyzed by rumen bacteria to the aglycone, NPOH, which is then absorbed and oxidized to 3-nitropropionic acid (Majak and Pass 1989), a potent inhibitor of mitochondrial enzymes essential to respiration (Alston et al. 1977, Coles et al. 1979).

Rumen bacteria also have the capacity to degrade and detoxify NPOH, and the rate of degradation can be enhanced by increasing the amount of protein in the diet (Majak et al. 1998). The detoxification of NPOH by Denitrobacterium detoxificans, a recently identified rumen bacterium, involves the reduction of the nitro group to the much less toxic amino group (Anderson et al. 1993, 1997). One strain of this bacterium (MAJ1) originated from the rumen bacteria of cattle grazing our study area in the Cariboo (Anderson et al. 2000).

The objectives of this study were to determine which age class of cattle was most susceptible to TMV, to record clinical signs of poisoning under range conditions, and to confirm the efficacy of protein supplements for the prevention of TMV poisoning. The effect of prior exposure to TMV on susceptibility to TMV was also determined. An additional objective during the 6 year study was to evaluate the detoxification potential of rumen bacteria using in vitro assays.

\section{Materials and Methods}

Two, 40 ha forest pastures (designated $\mathrm{A}$ and B) at Sixtyone Creek, B.C. ( $51^{\circ} 14^{\prime}$ $\mathrm{N}$ lat., $121^{\circ} 34^{\prime} \mathrm{W}$. long.) used for this study were described earlier (Majak et al. 1996).Pinegrass (Calamagrostis rubescens Buckl.) was the principal native grass and the distribution of the 10 major forbs is described in Table 1. It should be noted that in the earlier study (Majak et al. 1996) the 2 major forbs at the forest site were incorrectly assigned to a grassland site and vice versa. A third pasture (designated $\mathrm{C}$ ) of equal area was added in 1993 by enclosing the area between pastures $A$ and $\mathrm{B}$ with permanent fences. This pasture had been clearcut logged in 1977. The average density of timber milkvetch (TMV, 12 plants $\mathrm{m}^{-2}$ ) in pastures A and B (Majak et al. 1996) was significantly higher $(\mathrm{P}<$ $0.05)$ than in pasture $C\left(6\right.$ plants $\left.\mathrm{m}^{-2}\right)$. The average TMV basal area per plant $(3.14$

Table 1. Frequency ${ }^{1}$ of 10 major forbs at Sixtyone Creek.

\section{Species}

Fragaria virginiana Duchesne

Achillea millefolium $\mathrm{L}$.

Taraxacum officinale Weber

Antennaria parvifolia Nutt.

Agoseris glauca var. dasycephla (T. \& G.) Jeps

Solidago sphathulata DC.

Galium boreale L.

Aster conspicuous Lindl.

Erigeron speciosus var. speciosus (Lindl.) DC. Melampyrum lineare Desr.

Total

${ }^{1}$ Estimated from 120, 1-m² plots (Majak et al. 1996).

$\left.\mathrm{cm}^{2}\right)$ did not differ among the pastures $(\mathrm{P}$ $=0.13$ ). Estimates of the miserotoxin content of TMV at the site vary from $2.5 \%$ to $3.7 \%$ on a dry weight basis (Majak et al. 1996, Majak and Wikeem 1986).

During 1993 and 1995-2000, cattle on test were divided into 2 groups, one of which received protein supplements in molasses blocks and the other served as a control. The treated cattle were exposed to the molasses blocks at Pass Lake on forest range near Kamloops, B.C. for at least 2 weeks before grazing commenced at Sixtyone Creek where blocks were given free choice for the duration of the 6 week study each year. The blocks contained $32 \%$ crude protein (Uniblok Canada, Rockyford, AB) including canola, corn gluten and feather meal $(20 \%)$, urea $(12 \%)$, minerals and salt. The control group received a block of cobalt iodized stock salt.

Rumen samples were obtained from the Hereford cows with the stomach pump sampling technique using a speculum to insert a plastic hose attached to a manual pump. Animals were cared for under the guidelines of the Canadian Council on Animal Care. The details of the anaerobic in vitro procedures and the spectrophotometric methods for determining rates of $\mathrm{NPOH}$ disappearance in rumen fluid were reported earlier (Majak 1992). Using a portable generator to maintain a waterbath at $39^{\circ} \mathrm{C}$, samples of rumen fluid were anaerobically incubated with NPOH (2 $\mathrm{mM}$ ) under field conditions, then subsamples were treated with the protein precipitant and cooled prior to transportation and spectrophotometric determination. Rates of NPOH disappearance in rumen fluid in vitro were determined at biweekly intervals for each animal on test.

\section{Grazing Trial}

Results of the 1993 grazing trial at Sixtyone Creek were reported earlier (Majak et al. 1996) except for the specific cases of timber milkvetch (TMV) poisoning, which are reported here (Table 2). Two groups of 10 Hereford cow-calf pairs were used in 1993, including 10 first-calf heifers ( 2 years old) and 10 cows, 4 to 10 years old (Table 2). Each group contained 5 heifers and 5 older cows. One group was given protein supplements in pasture $B$ and the control group grazed pasture A without any supplement.

In 1994, 2 types of protein blocks (Majak et al. 1998) were tested using 2 groups of 12 cow-calf pairs. The cows were 2 to 8 years old and there were no cases of TMV poisoning (unpublished data, Majak, W.). Grazing started each year in pasture C which was subdivided into 2 adjacent fields with electric fencing. After approximately 2 weeks of grazing in the clearcut compartment, 1 group moved east to $A$ and the other was moved west to B for the remainder of the 6 week grazing trial.

\section{5 and 1996 Grazing Trials}

In 1995 and 1996, 2 groups of 12 cowcalf pairs were tested with and without protein supplements. Since the 1993 grazing trial and previous studies during 19891992 (Majak et al. 1996, 1998) failed to produce signs of TMV poisoning among older cows, only younger cattle (2 to 3 years old) were used. A further modification in 1995 and 1996 involved the yearly purchase of 12 first-calf heifers from Alberta. These animals had not been previously exposed to TMV. The objective was to determine whether unexposed, "naive" animals of prairie origin were more susceptible to TMV poisoning than 
Table 2. Age, origin and number of cows in grazing studies during 1993-2000 and incidence and degree ${ }^{1}$ of TMV poisoning in control and supplement groups.

\begin{tabular}{|c|c|c|c|c|c|c|c|c|c|c|c|c|c|c|}
\hline \multirow{3}{*}{ Year } & \multirow{3}{*}{$\mathrm{n}$} & \multirow{3}{*}{$\frac{\text { Age }}{\text { (years) }}$} & \multicolumn{6}{|c|}{ Control group } & \multicolumn{6}{|c|}{ Supplement group } \\
\hline & & & \multicolumn{2}{|c|}{ Early } & \multicolumn{2}{|c|}{ Acute } & \multicolumn{2}{|c|}{ Chronic } & \multicolumn{2}{|c|}{ Early } & \multicolumn{2}{|c|}{ Acute } & \multicolumn{2}{|c|}{ Chronic } \\
\hline & & & $\mathrm{AB}^{2}$ & $\mathrm{BC}$ & $\mathrm{AB}$ & $\mathrm{BC}$ & $\mathrm{AB}$ & $\mathrm{BC}$ & $\mathrm{AB}$ & $\mathrm{BC}$ & $\mathrm{AB}$ & $\mathrm{BC}$ & $\mathrm{AB}$ & $\mathrm{BC}$ \\
\hline 1993 & 20 & $2-10$ & - & $2^{3}$ & - & $1^{3}$ & - & 1 & - & 0 & - & 0 & - & 0 \\
\hline 1995 & 24 & $2-3$ & 0 & 2 & 3 & 0 & 2 & 0 & 0 & 0 & 0 & 0 & 1 & 0 \\
\hline 1996 & 24 & $2-3$ & 0 & 0 & 1 & 0 & 1 & 1 & 0 & 0 & 0 & 0 & 0 & 0 \\
\hline 1998 & 30 & 1 & 0 & 0 & 0 & 0 & 0 & 0 & 0 & 0 & 0 & 0 & 0 & 0 \\
\hline 1999 & 24 & 2 & 4 & 1 & 0 & 1 & 0 & 0 & 0 & 0 & 1 & 0 & 0 & 0 \\
\hline 2000 & 21 & 3 & 0 & 0 & 0 & 0 & 2 & 3 & 0 & 0 & 0 & 0 & 0 & 0 \\
\hline Total & $143^{4}$ & & \multicolumn{2}{|c|}{9} & \multicolumn{2}{|c|}{6} & \multicolumn{2}{|c|}{10} & \multicolumn{2}{|c|}{0} & \multicolumn{2}{|c|}{1} & \multicolumn{2}{|c|}{1} \\
\hline
\end{tabular}

Clinical signs designated as early, acute, or chronic.

${ }^{2}$ In 1995 to 2000, origin indicated by AB (Alberta) or BC (British Columbia).

${ }^{3}$ First-calf heifers from B.C. with an unknown history of exposure to TMV.

47 and 72 cows in control and supplement groups respectively.

cows from B.C. In each year, in vitro rates of detoxification were determined after cattle were on pasture $\mathrm{C}$ for 2 weeks (Date $1)$, after they were in pastures $A$ and $B$ for 2 weeks (Date 2) and at the end (Date 3).

Grazing trials at Sixtyone Creek were not conducted in 1997 to permit the forage on the range pastures to recover from grazing pressure. After 5 years of grazing (1992 - 1996), the TMV biomass had been substantially reduced. During that period, the average stocking rate was $3.5 \mathrm{ha} / \mathrm{AUM}$ which is heavier than the recommended rate of $4 \mathrm{ha}$ /AUM for that area. The increased grazing pressure promoted the utilization of TMV. Subsequently, the average stocking rate was set at 4.1 ha/AUM

\section{8, 1999, and 2000 Grazing Trials}

Prior exposure to timber milkvetch (TMV) appears to be a critical factor in subsequent resistance to TMV. It was not known whether this exposure was critical at the suckling calf stage or at the yearling heifer stage. The 1998 season was the first phase of a 3 year program to assess the susceptibility of female cattle to TMV poisoning between the state of puberty and maturity.

Thirty heifer calves were purchased in 1997. Half were from the prairie region of Alberta, where TMV is not available, and half were from the Cariboo region of B.C., where TMV is abundant. They were overwintered and bred in Kamloops before the 1998 TMV grazing season when they were divided into 2 groups of 15 . The control group contained 8 heifers from B.C. and 7 from Alberta. The supplement group contained 8 heifers from Alberta and 7 from B.C. The supplement group was given protein blocks free choice and the other served as a control.
The 1999 season was the second phase of the 3-year program that would test the effect of age on the susceptibility of lactating cows to TMV. Only 24 first-calf heifers were available for TMV range trials in 1999. Due to calving problems, it was not possible to assign the same animals to each supplement group in 1999 but they were kept in the same groups in 1999 and 2000. Each group of 12 consisted of 5 cow-calf pairs from Alberta and 7 from B.C. One group was given protein supplements and the other served as a control.

The third phase was conducted in the summer of 2000 when the susceptibility of these same heifers, now as second-calf heifers, was assessed. In the 2000 trial, the control group consisted of 5 cow-calf pairs from B.C. and 5 from Alberta. The treated group had 6 cow-calf pairs from B.C. and 5 from Alberta.

\section{Statistical Analysis}

Data on the incidence of poisoning in cattle were analyzed using logistic regression (Hosmer and Lemeshow 1989). A binary variable $\mathrm{Y}$ was created for each animal, and was assigned the value $\mathrm{Y}=1$ if the animal showed symptoms of poisoning and 0 if not. Logistic regression estimates the relationship $P(Y=1)=$ $1 /\left(1+\exp \left(-\left(a+b^{*} X\right)\right)\right)$ where $P(Y=1)$ is the probability that an animal showed symptoms of poisoning, $a$ is a constant estimated from the data, $\mathrm{X}$ is an independent treatment variable, and $b$ is the estimate of slope with respect to the independent variable. The independent treatment variable $\mathrm{X}$ was a binary variable to allow estimating the magnitude of the response across 2 groups. The variable used depended on the comparison of interest. The risk of poisoning for a group of cattle was estimated as $\sum Y / n$ where $\sum Y=$ the number of animals that exhibited symptoms of poisoning and $n=$ the total number of animals in the group. The odds of an animal in a group exhibiting symptoms of poisoning were estimated as $\sum Y /(n$ $\left.\sum Y\right)$ and describe how likely the symptoms of poisoning occurred in a group. Since the variable $\mathrm{X}$ was always a binary variable, the odds ratio for the 2 groups was estimated directly from the logistic regression equation as $\exp (b)$, and describes how much more likely poisoning occurred in 1 group compared with another. All logistic regressions were conducted using SPSS (SPSS Inc. 2000).

The effect of supplementation on the incidence of poisoning in cattle was estimated by logistic regression using data from all trials. The variable $\mathrm{X}$ was assigned the value 0 for control animals (no supplementation) and 1 for supplemented animals, and logistic regression used to determine if the incidence of poisoning was influenced by supplementation.

The effect of animal age on the incidence of poisoning in cattle was estimated by logistic regression using data for the control (unsupplemented animals) from the 1993 and 1998-2000 trials. Supplemented animals were not used in this analysis since the incidence of poisoning was low in all trials. The variable $\mathrm{X}$ was assigned the value 1 if the animals were $2-3$ years old, and 0 if the animals were either 1 year old or 4+ years old, and logistic regression used to determine the significance of the effect.

The effect of animal origin on the incidence of poisoning was determined using data from 1995-1996 and 1998-2000 since these trials all contained animals from both locations. Supplemented animals were not used in this analysis. The variable $X$ was assigned the value 1 if the animals came from Alberta and 0 if they 
came from B.C., and logistic regression used to compare the incidence of poisoning among cattle originating from Alberta and B.C.

In vitro detoxification rates from 1995 to 2000 were analysed using repeated measures ANOVA (PROC GLM, SAS 1995). During 1995 to 2000 , each experiment was a $2 \times 2$ factorial with 2 treatments (with or without protein supplements) and 2 origins of livestock (Alberta or B.C.) with a treatment $\mathrm{x}$ origin interaction (SAS 1995), which was not statistically significant. These were considered between-subject effects and sampling dates within each year were considered within-subject effects since measurements were made on the same animals over time. Data were analysed separately for each year since different animals were used in 1995, 1996 and 1998-2000. Also, animal numbers varied from 1998-2000, so these years were analysed separately. A significance level of 0.05 was used throughout the study.

\section{Results}

\section{Clinical Signs}

In early signs of timber milkvetch (TMV) poisoning, we observed that animals may be gaunt or slightly bloated with some respiratory abnormalities and general lethargy. These signs invariably progress to acute poisoning with continued exposure and animals with early or subacute symptoms were usually removed from the study. Acute signs of TMV poisoning were manifested as incontinence, loss of hindquarter co-ordination, excessive salivation, reluctance to move, a strong tendency to become recumbent and general untractability. In chronic poisoning, there is permanent damage manifested as unthriftiness, diarrhea, loss of stamina, and clicky heels (James et al. 1980, Majak et al. 1981). Signs of chronic poisoning were frequently delayed and were often manifested when cattle were suddenly exerted and forced to travel. Affected animals will usually lag behind the rest of the herd. This was often seen after the completion of the grazing trial when cattle were moved to their home range. In this study, an incident of TMV poisoning was classified as the occurrence of clinical signs of early, acute, or chronic poisoning in one animal and on one or more days of the season.

\section{Effect of Supplements}

The incidence of poisoning in control animals was $35 \%(25 / 71)$ and was $3 \%$ $(2 / 72)$ in supplemented animals (Table 2$)$. The odds of poisoning were 0.54 ( 25 poisoned: 46 not poisoned) and 0.03 (2 poisoned: 70 not poisoned) in the control and supplemented groups respectively. Logistic regression indicated that supplementation significantly reduced the odds of poisoning $\left(\chi^{2}=28.2 ; \mathrm{df}=1 ; \mathrm{P}<\right.$ $0.0001)$. The parameter estimates $( \pm \mathrm{SE})$ were $a=-0.610( \pm 0.248)$ and $b=-2.945$ $( \pm 0.759)$. The estimate of $b$ was significant $(\mathrm{t}=15.1 ; \mathrm{df}=1 ; \mathrm{P}<0.0001)$. The odds of poisoning were $19.0(95 \% \mathrm{CI}=$ $4.3,84.2$ ) times greater in the unsupplemented groups compared with the supplemented groups.

Two-year-old heifers with an unknown history of exposure to timber milkvetch (TMV) were used for the first time in the 1993 TMV grazing trial. Three of these 2year olds that were part of the unsupplemented group showed signs of TMV poisoning (Table 2) and were removed from the trial due to acute or early signs of TMV poisoning. In 1995, 3 of the 6 naive heifers in the control group suffered from acute TMV poisoning, and were removed from the trial 2 weeks before its conclusion (Table 2). In 1996, there was a low incidence of TMV poisoning. Only 1 Alberta heifer in the control group was prematurely withdrawn from the trial. The low incidence of poisoning in 1996 was attributed to the overgrazed condition of the TMV range. Grazing at the Sixtyone Creek pastures was discontinued in 1997 to permit recovery of TMV and other forage.

In summary, the control group yielded 25 cases of TMV poisoning during the 6year study, compared with 2 for the supplement group. The supplement increased rates of TMV detoxification $(>50 \%)$ in only 1 of the 5 years of testing (Table 3 ). The innate capacity to transfer rumen microbial activity between cattle in close proximity and the natural enrichment of rumen microbial populations (Anderson et al. 1998) might elevate rates of detoxification regardless of treatment.

\section{Effect of Age}

Age classes in the control groups were compared across years because it was not feasible to have each age class in each year and the experimental site could not accommodate more cattle. Data for 1993 and 1998-2000 were combined since the number of animals in any one year were low. The incidence of poisoning was $5 \%$ (1/20) for 1 year-old (1998) and 4+ yearold animals (1993) compared with 53\% (14/27) for 2-3 year-old animals in 1993, 1999, and 2000 (Table 2). The odds of poisoning were $0.05(1 / 19)$ and 1.08 $(14 / 13)$ in the respective groups. Logistic regression indicated that the effect of age was significant $\left(\chi^{2}=13.5 ; \mathrm{df}=1 ; \mathrm{P}<\right.$ $0.0001)$ and the parameter estimates $( \pm$ SE) were $a=-2.943( \pm 1.025)$ and $b=$ $3.017( \pm 1.095)$. The estimate of $b$ was significant $(\mathrm{t}=7.6 ; \mathrm{df}=1 ; \mathrm{P}<0.0001)$. The odds of poisoning were 20.4 (95\% CI $=2.4,174.8$ ) times greater for $2-3$ year old animals compared with the other age classes. Older cows were also used in TMV studies during 1990 to 1992 without showing ill effects (Majak et al. 1996).

There was no incidence of timber milkvetch (TMV) poisoning among yearling heifers in 1998 (Table 2). This concurs with local producers' experience that non-lactating females are unlikely to be susceptible to TMV. In 1999, a supplemented Alberta 2-year old first-calf heifer showed early signs of TMV poisoning and she was removed from the trial. This heifer was part of the previous year's group that was not given access to protein blocks and it is possible that she was unfamiliar with the supplement. Toward the end of the trial, a 2-year old B.C. heifer in the control group showed acute signs of TMV poisoning and remained on the range with her calf due to respiratory problems and her inability to trail. Four other 2-year old heifers from Alberta in the control group also showed early signs of poisoning (Table 2).

The 2000 season concluded a 3-year investigation to assess the susceptibility of young female cattle to poisoning by TMV. There were no acute cases of TMV poisoning in 3-year old cows at Sixtyone Creek in 2000 (Table 2). However, on return to the home range at Pass Lake, 3 control cows ( 2 from B.C. and 1 from Alberta) developed the "clicky heel" syndrome associated with chronic TMV poisoning. This clinical sign did not appear until cattle were moved some considerable distance and the condition persisted into winter. As well, 2 additional cows from the control group showed the same chronic signs in the fall (Table 2). It should be noted that none of these cows showed acute signs at Sixtyone Creek in 2000 or in the previous year. 
Table 3. Average rates of NPOH detoxification by ruminal bacteria in cattle grazing TMV and treated with or without protein supplements.

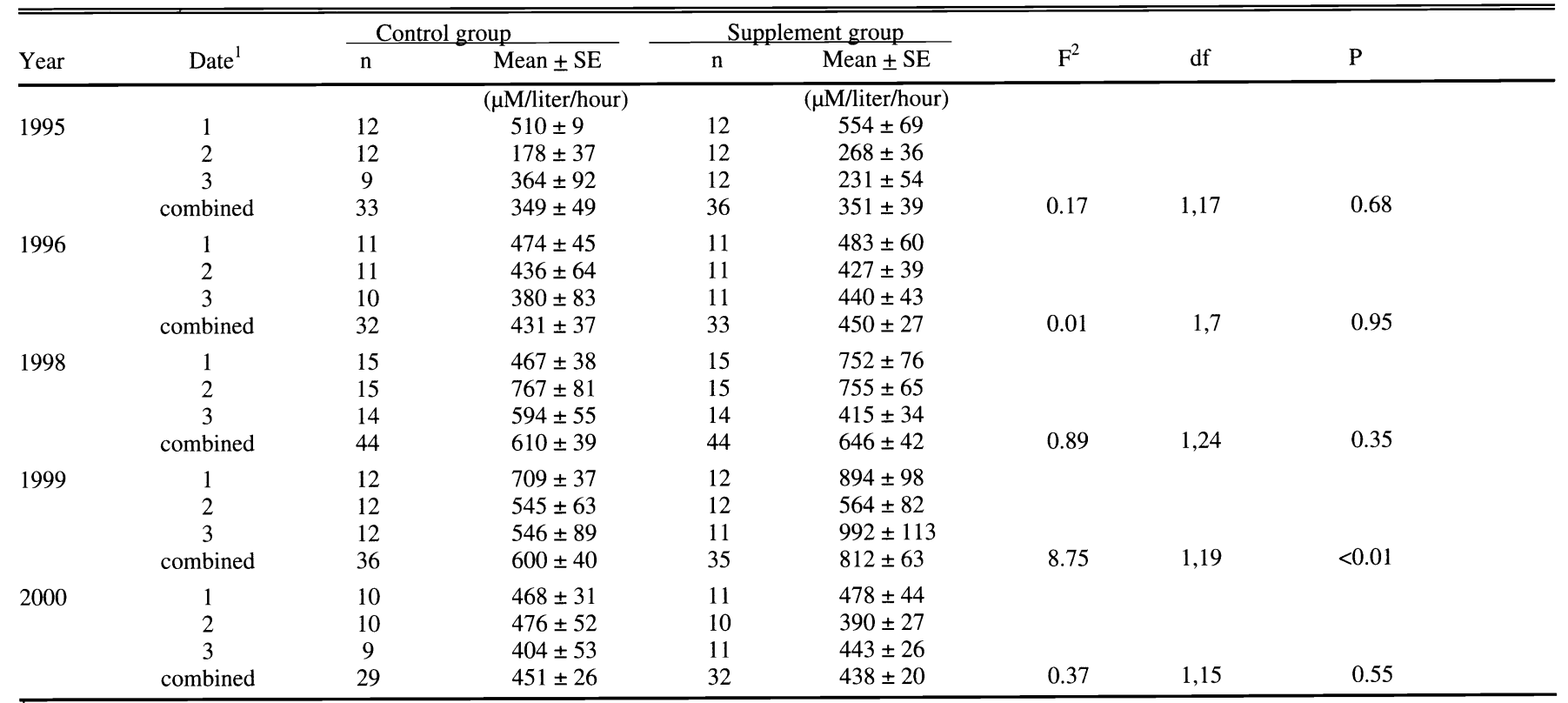

Date 1 determination in pasture $\mathrm{C}$; dates 2 and 3 in pastures $\mathrm{A}$ and $\mathrm{B}$.

${ }^{2}$ F-test for the effects of supplement.

\section{Effect of Origin}

The effect of origin was compared across years in the control group from 1995 to 2000 (Table 2). The incidence of poisoning was $25 \%(8 / 32)$ for indigenous cattle originating in B.C. and $45 \%$ (13/29) for naive cattle originating from Alberta. The odds of poisoning were $0.33(8 / 24)$ and $0.81(13 / 16)$ respectively for cattle originating from B. C. and Alberta. Logistic regression indicated that the effect of origin was marginally significant $\left(\chi^{2}=2.7 ; \mathrm{df}=1 ; \mathrm{P}=0.10\right)$ and the parameter estimates $( \pm \mathrm{SE})$ were $a=-1.099( \pm$ $0.408)$ and $b=0.891( \pm 0.553)$. The estimate of $b$ was also marginally significant $(t=2.6 ; \mathrm{df}=1 ; \mathrm{P}=0.10)$. The odds of poisoning were $2.4(95 \% \mathrm{CI}=0.8,7.2)$ times greater for cattle originating from Alberta compared to those originating from B. C. The $95 \%$ confidence interval overlapped with 1 , so these results can only be taken as suggestive of an effect of origin.

\section{In vitro Detoxification Rates}

The average daily intake of the molasses blocks was 1.4 and $1.8 \mathrm{~kg}$ per cow-calf pair in 1995 and 1996 respectively. There was no rate difference between supplement and control groups in 1995 and 1996 (Table 3). The average daily intake of the molasses blocks was $0.6 \mathrm{~kg}$ per head in 1998 and 1.1 and $1.6 \mathrm{~kg}$ per cow-calf pair in 1999 and 2000. In 1998, in vitro rates of detoxification were initially determined in spring when the cattle were on tame grass pastures before being transported to forest range. These rates were relatively low $(148 \mu \mathrm{M} /$ liter/hour \pm 16 on May 12$)$ but they escalated dramatically after 2 weeks on pasture $\mathrm{C}$. The rate for the supplement group increased to $752 \mu \mathrm{M} /$ liter/hour (SE $=76)$ and to $467 \mu \mathrm{M} /$ liter/hour $(\mathrm{SE}=38)$ for the unsupplemented group (Table 3). A significant date*treatment term $(\mathrm{F}=10.2$; $\mathrm{df}=1,24 ; \mathrm{P}=0.0002$ ) indicated that changes in detoxification rates across time were not consistent among groups. Detoxification rates were highest on date 1 for the supplement group, but the control group was highest on date 3 (Table 3 ). These results show that the rumen microbe populations can shift to effectively detoxify timber milkvetch (TMV), and thus permit a high level of tolerance in cattle grazing TMV. The rates of detoxification were higher for the supplement group compared with the control group in 1999 (Table 3) but no difference was observed in 2000 .

The naive Alberta yearlings had lower $(\mathrm{P}<0.05)$ initial rates of TMV detoxification (Table 4) during 1998. During the 1999 trial, ruminal rates of detoxification were consistently lower $(\mathrm{P}<0.05)$ for the heifers from Alberta than for those from B.C. (Table 4). This was most apparent towards the end of the trial when the average rates differed by $300 \mu \mathrm{M} /$ liter/hour. The supplement also had the largest impact at that time when, on average, the supplement group exceeded the control group by $400 \mu \mathrm{M} /$ liter/hour (Table 3 ). There was no difference in rates in 2000 . The lower rate of TMV detoxification for yearling heifers not previously exposed to TMV suggests that, to acquire resistance to TMV, exposure to TMV at the suckling calf stage is critical. Native cattle yielded higher rates of TMV detoxification (> $25 \%$ ) on only two of the five years of testing (Table 4). The innate capacity to transfer rumen microbial activity between cattle in close proximity and the natural enrichment of rumen microbial populations might elevate rates of detoxification over time regardless of origin.

\section{Discussion}

The 1998-2000 study at Sixtyone Creek confirmed that first-calf heifers are most susceptible to timber milkvetch (TMV) poisoning and they can show acute signs, second-calf heifers can develop delayed, chronic symptoms and yearling heifers are least susceptible (Table 2). To acquire resistance to TMV, exposure to TMV at the suckling calf stage is critical. Previous exposure to TMV can have a significant impact on subsequent resistance to TMV. As well, we have confirmed that protein supplements provide adequate protection from TMV, especially for native cattle of B.C. that are adapted to TMV. Clinical 
Table 4. Average rates of NPOH detoxification by ruminal bacteria in cattle grazing TMV and originating from either British Columbia or Alberta.

\begin{tabular}{|c|c|c|c|c|c|c|c|c|}
\hline \multirow[b]{2}{*}{ Year } & \multirow[b]{2}{*}{ Date $^{1}$} & \multicolumn{2}{|c|}{ British Columbia } & \multicolumn{2}{|c|}{ Alberta } & \multirow[b]{2}{*}{$\mathrm{F}^{2}$} & \multirow[b]{2}{*}{$\mathrm{df}$} & \multirow[b]{2}{*}{$P$} \\
\hline & & $\mathrm{n}$ & Mean $\pm \mathrm{SE}$ & $\mathrm{n}$ & Mean $\pm S E$ & & & \\
\hline 1995 & $\begin{array}{c}1 \\
2 \\
3 \\
\text { combined }\end{array}$ & $\begin{array}{l}12 \\
12 \\
12 \\
36\end{array}$ & $\begin{array}{c}(\mu \mathrm{M} / \text { liter/hour }) \\
460 \pm 69 \\
254 \pm 42 \\
308 \pm 76 \\
341 \pm 39\end{array}$ & $\begin{array}{c}12 \\
12 \\
9 \\
33\end{array}$ & $\begin{array}{c}(\mu \mathrm{M} / \text { liter/hour }) \\
603 \pm 85 \\
192 \pm 34 \\
261 \pm 65 \\
360 \pm 49\end{array}$ & 0.46 & 1,17 & 0.50 \\
\hline 1996 & $\begin{array}{c}1 \\
2 \\
3 \\
\text { combined }\end{array}$ & $\begin{array}{l}12 \\
12 \\
12 \\
36\end{array}$ & $\begin{array}{l}460 \pm 55 \\
473 \pm 48 \\
377 \pm 48 \\
437 \pm 29\end{array}$ & $\begin{array}{c}10 \\
10 \\
9 \\
29\end{array}$ & $\begin{array}{l}500 \pm 48 \\
382 \pm 54 \\
457 \pm 84 \\
446 \pm 36\end{array}$ & 0.18 & 1,17 & 0.68 \\
\hline 1998 & $\begin{array}{c}1 \\
2 \\
3 \\
\text { combined }\end{array}$ & $\begin{array}{l}15 \\
15 \\
14 \\
44\end{array}$ & $\begin{array}{l}699 \pm 71 \\
851 \pm 85 \\
557 \pm 43 \\
706 \pm 43\end{array}$ & $\begin{array}{l}15 \\
15 \\
14 \\
44\end{array}$ & $\begin{array}{l}519 \pm 62 \\
671 \pm 49 \\
453 \pm 55 \\
550 \pm 35\end{array}$ & 7.40 & 1,24 & $<0.02$ \\
\hline 1999 & $\begin{array}{c}1 \\
2 \\
3 \\
\text { combined }\end{array}$ & $\begin{array}{l}14 \\
14 \\
14 \\
42\end{array}$ & $\begin{array}{l}885 \pm 82 \\
658 \pm 61 \\
883 \pm 119 \\
809 \pm 53\end{array}$ & $\begin{array}{c}10 \\
10 \\
9 \\
29\end{array}$ & $\begin{array}{l}685 \pm 47 \\
409 \pm 65 \\
567 \pm 81 \\
553 \pm 42\end{array}$ & 15.01 & 1,19 & $<0.01$ \\
\hline 2000 & $\begin{array}{c}1 \\
2 \\
3 \\
\text { combined }\end{array}$ & $\begin{array}{l}11 \\
11 \\
11 \\
33\end{array}$ & $\begin{array}{l}478 \pm 43 \\
483 \pm 36 \\
418 \pm 49 \\
460 \pm 25\end{array}$ & $\begin{array}{c}10 \\
9 \\
9 \\
28\end{array}$ & $\begin{array}{l}467 \pm 33 \\
371 \pm 45 \\
434 \pm 15 \\
426 \pm 20\end{array}$ & 0.87 & 1,15 & 0.37 \\
\hline
\end{tabular}

${ }_{2}$ Date 1 determination in pasture $\mathrm{C}$; dates 2 and 3 in pastures $\mathrm{A}$ and $\mathrm{B}$.

${ }^{2}$ F-test for the effects of supplement.

signs of TMV poisoning were never observed in calves.

Overall, the results indicate that supplementation and animal age were the most important factors determining the likelihood of poisoning, and that geographic origin had a marginal influence. There was considerable variability in detoxification rates. Individual differences indicated that there could be a tenfold variation in rates of TMV detoxification among cattle regardless of treatment. In 1995 for example, the range of values for the control group was 10-620 ( $\mu \mathrm{M} /$ /iter/hour) and for the supplement group it was 81-425. In 1996, the values ranged from 193-740 and 226-759 for the 2 groups, respectively. Clearly, some cattle had acquired a resistance to TMV poisoning as evidenced by their enhanced rates of TMV detoxification regardless of treatment. Changes from year to year may reflect differences among animals or in forage quality. The absence of treatment differences during 1995 and 1996 (Table 3) might be attributed to the adaptation of the control groups to TMV and the natural in vivo enrichment of detoxifying bacteria (Anderson et al. 1998). As well, it is documented that a transfer of rumen microbial activity can occur between treated and control groups by contact or through close proximity (Cheng et al. 1985). This type of contact would have been possible during the ini- tial grazing interval on pasture $\mathrm{C}$ when the cattle were in adjacent fields. The animals also shared a common squeeze chute when sampled. It should also be noted that in earlier studies (Majak 1992) control groups on domesticated feeds showed much lower rates of detoxification (60-262).

The limitations of the stomach pump sampling technique should be noted. Unlike obtaining whole rumen contents via cannula, the tube method yields fluid samples with a variable proportion of saliva. Rumen bacteria are primarily associated with the particulate phase of rumen digesta (McAllister et al. 1994). This phase is obtained in limited quantities by the tube method. Also, the typical volume of the composite sample via cannula ( 500 $\mathrm{ml}$ ) is much larger and more representative of rumen contents than the smaller tube sample $(50 \mathrm{ml})$. When duplicate samples $(n=74)$ were obtained by the tube method, the agreement between sample rates was acceptable. The average difference was $12.5 \%$ with a $95 \%$ confidence interval of 3.2 to $23 \%$. To avoid further trauma, it was not feasible to obtain rumen samples from affected animals due to their poor and unstable condition.

Rates of detoxification were not detectably affected by protein supplementation in 2000 (Table 3) and effect of origin was less pronounced in 2000 than in
1999 (Table 4). The latter suggests that the effect of origin on rates of detoxification declines in second-calf heifers due to previous exposure to timber milkvetch (TMV). Higher rates were evident for B.C. cattle during 1998-2000 but not during 1995-96 (Table 4). Cattle from B.C. were purchased from the Cariboo region in 1998 where TMV is a major component of their diet (Majak et al. 1996). In contrast, B.C. cattle in 1995 and 1996 were purchased from the greater Kamloops region where TMV is a minor or occasional component in the Douglas Fir forest.

It is also possible that tolerance to TMV could be mediated by hepatic mechanisms. Amino acid conjugation of natural products by hepatic enzymes is known to occur (Scheline 1991) and amino acid conjugates of 3-nitropropionic acid (NPA) have been detected in nature (Majak et al. 1998). The relative rates of hepatic bioactivation (oxidation of NPOH to NPA) and detoxification (reduction or conjugation) might also be a factor in the differential toxicity of NPOH to cattle.

\section{Management Implications}

Incidents of early, acute and chronic timber milkvetch (TMV) poisoning were documented using 143 cows in a 6-year study at a lodgepole pine forest site in 
B.C. Lactating first-calf heifers were most susceptible to TMV and they showed acute signs of poisoning. Second calf heifers showed delayed chronic signs especially during exertion. Older cows and yearling heifers were the least susceptible. Heifers that were purchased in Alberta and not previously exposed to TMV were more prone to TMV poisoning than cattle that were native to B.C. Protein supplements provided adequate protection from TMV regardless of age or prior history.

\section{Literature Cited}

Alston, T.A., L. Mela, and H.J. Bright. 1977. 3-Nitropropionate, the toxic substance of Indigofera, is a suicide inactivator of succinate dehydrogenase. Proc. Natl. Acad. Sci. USA 74:3767-3771.

Anderson, R.C., M.A. Rasmussen, and M.J. Allison. 1993. Metabolism of the plant toxins nitropropionic acid and nitropropanol by ruminal microorganisms. Appl. Environ. Microbiol. 59:3056-3061.

Anderson, R.C., W. Majak, Rasmussen, M.A., and M.J. Allison. 1998. Detoxification potential of a new species of ruminal bacteria that metabolize nitrate and naturally occurring nitrotoxins, p. 154-158. In: T. Garland and A.C. Barr (eds.), Toxic plants and other natural toxicants. CAB International, New York, N.Y.

Anderson, R.C., M.A. Rasmussen, A.A. DiSpirito, and M.J. Allison. 1997. Characteristics of a nitropropanol-metabolizing bacterium isolated from the rumen. Can. J. Microbiol. 43:617--624.
Anderson, R.C., M.A. Rasmussen, N.S. Jensen, and M.J. Allison. 2000. Denitrobacterium detoxificans gen. nov., sp. nov., a ruminal bacterium that respires on nitrocompounds. Intern. J. Syst. Evol. Microbiol. 50:633-638.

Cheng, K.-J., R.C. Phillippe, G.C. Kozub, W. Majak, and J.W. Costerton. 1985. Induction of nitrate and nitrite metabolism in bovine rumen fluid and the transfer of this capacity to untreated animals. Can. J. Anim. Sci. 65:647-652.

Coles, C.J., D.E. Edmondson, and T.P. Singer. 1979. Inactivation of succinate dehydrogenase by 3-nitropropionate. J. Biol. Chem. 254:5161-5167.

Hosmer, D.W. and S. Lemeshow. 1989. Applied logistic regression. John Wiley \& Sons, New York.

James, L.F., W.J. Hartley, M.C. Williams, and K.R. Van Kampen. 1980. Field and experimental studies in cattle and sheep poisoned by nitro-bearing Astragalus or their toxins. Am. J. Vet. Res. 41:377-382.

Majak, W. 1992. Further enhancement of 3nitropropanol detoxification by ruminal bacteria in cattle. Can. J. Anim. Sci. 72:863-870.

Majak, W. and M.A. Pass. 1989. Aliphatic nitrocompounds, p. 144-159. In: P.R. Cheeke (ed.), Toxicants of Plant Origin, Vol. II Glycosides. CRC Press Inc., Boca Raton, Fla.

Majak, W. and B.M. Wikeem. 1986. Miserotoxin levels in fertilized Astragulus miser var serotinus. J. Range Manage. 39:130-131.

Majak, W., C. Hunter, and L. Stroesser. 1998. Tolerance in cattle to timber milkvetch (Astragalus miser var. serotinus) due to changes in rumen microbial populations, $\mathrm{p}$. 239-242. In: T. Garland and A.C. Barr (eds), Toxic plants and other natural toxicants. CAB International, New York, N.Y.
Majak, W., D.L. Johnson, and M.H. Benn. 1998. Detoxification of 3-nitropropionic acid and karakin by melanopline grasshoppers. Phytochem.. 49:419-422.

Majak, W., T. Udenberg, R.E. McDiarmid, and $H$. Douwes. 1981. Toxicity and metabolic effects of intravenously administered 3nitropropanol in cattle. Can. J. Anim. Sci. 61:639-647.

Majak, W., L. Stroesser, J.W. Hall, D.A. Quinton, and H.E. Douwes. 1996. Seasonal grazing of Columbia milkvetch by cattle on rangelands in British Columbia. J. Range Manage. 49:223-227.

Maricle, B., J. Tobey, W. Majak, and J.W. Hall. 1996. Evaluation of clinicopathological parameters in cattle grazing timber milkvetch. Can. Vet. J. 37:153-156.

McAllister, T.A., H.D. Bae, G.A .Jones, and K.-J. Cheng. 1994. Microbial attachment and feed digestion in the rumen. J. Anim. Sci. 72:3004-3018.

SAS Institute. 1995. SAS User's Guide Release 6.12. SAS Institute Inc., Cary, N.C.

Scheline, R.R. 1991. Handbook of mammalian metabolism of plant compounds. CRC Press, Boca Raton, Fla.

SPSS Inc. 2000. SPSS 10.0. Regression models. SPSS Inc., Chicago, Ill.

Wikeem, B.M., A. McLean, A. Bawtree, and D. Quinton. 1993. An overview of the forage resource and beef production on Crown land in British Columbia. Can. J. Anim. Sci. 73:779-794. 


\title{
Adesmia subterranea Clos germination physiology and pre- sowing treatments
}

\author{
CARLOS A. PARERA AND MONICA RUIZ
}

Authors are Senior Researcher and Research Assistant, Estación Experimental Agropecuaria San Juan, Instituto Nacional de Tecnología Agropecuaria. Calle 11 y Vidart, 5427 - Villa Aberastain, San Juan, Argentina (parera@correo.inta.gov.ar).

Abstract

The genus Adesmia (Fabaceae, Papilionoideae) is one of the scarce forage resources at high altitude and arid zones of South America. Its germination behavior has not been examined. Seeds of Adesmia subterranea "Cuerno de Cabra" were pretreated with sulfuric acid (1, 3, and 5 minutes soaking) and mechanical scarification to determine their impact upon dormancy and percentage and speed of germination. Treatments were evaluated under a range of constant temperatures $\left(5\right.$ to $\left.30^{\circ} \mathrm{C}\right)$ and 2 day/night cycles resembling the extreme environmental conditions of this species habitat. Water uptake and leachate conductivity were higher in the seeds scarified mechanically or with 5 minutes chemical scarification. These treatments also had the greatest total germination and rate at all temperatures in a petri dish germination test. However, in a cell tray experiment using a commercial substrate, the highest seedling emergence and rate were observed with chemical scarification ( 5 and 3 minutes). The high amount of leakage caused by the scarifications affected emergence in a nonsterile media. The results indicate that $A$. subterranea seeds have an impermeable seed coat which restricts water uptake, and the efficiency of sulfuric acid scarification to overcome seed coat impermeability and improve germination and emergence.

Key Words: Legumes, scarification, hard seed coat, imbibition, temperature

The genus Adesmia (Fabaceae, Papilionoideae), endemic to South America, includes more than 230 species (Burkart 1967). Widely distributed in the arid regions of Chile, Argentina, Bolivia, Perú, and southern Brazil, Adesmia provides forage for guanacos, goats, and small animals and wood for peasants at high altitude (Cajal 1983). In Patagonia (Argentina) different species of Adesmia are part of the goat diet (Pelliza-Sbriller et al. 1985). Adesmia subterranea "Cuerno de Cabra" a flat small bush, occurs between 3,000 and 4,000 $\mathrm{m}$ in the Andes mountains of Chile and Argentina (Kiesling 1994). Information on its propagation and germination behavior is not available.

The dormancy imposed by hard seed coats has been reported as a mechanism to survive extreme harsh environmental conditions, and it is a common phenomenon in leguminous seeds (Bradbeer 1988) and other families and species (Egley 1989). At high altitude, the polyphenols accumulated in thick seed coats also inhibit germination in several species (Gutterman 1993). According to

Research was funded in part by SECyT (PICT 08-3700)

Manuscript accepted 9 Aug. 2002.
Resumen

El género Adesmia (Fabaceae, Papilionoideae) es uno de los escasos recursos forrajeros de zonas áridas y de altura en Sud América. El comportamiento de la germinación no ha sido evaluado hasta el momento. Semillas de Adesmia subterranea "Cuerno de Cabra" fueron pretratadas con ácido sulfúrico (inmersión 1, 3, y 5 minutos) y escarificadas mecánicamente para determinar su impacto sobre la dormancia, el porcentaje de germinación y la velocidad de germinación. Los tratamientos fueron evaluados en un rango de temperaturas constantes (de 5 a $30{ }^{\circ} \mathrm{C}$ ) y en 2 ciclos de día/ noche similares a las extremas condiciones climáticas del habitat de esta especie. La imbibición y la conductividad eléctrica del sobrenadante fueron superiores en las semillas escarificadas mecánicamente o las escarificadas con ácido 5 minutos. Esos tratamientos también presentaron el mayor porcentaje y velocidad de germinación sobre papel en todas las temperaturas evaluadas. Sin embargo, cuando se utilizó un sustrato comercial el mayor porcentaje y velocidad de emergencia se observó en las semillas escarificadas químicamente durante 5 y 3 minutos. Los resultados indican que las semillas de $A$. subterranea poseen una cobertura impermeable que impide el ingreso del agua afectando la germinación y que la escarificación con ácido sulfúrico es muy eficiente para facilitar el ingreso del agua y consecuentemente mejorar la germinación y la emergencia

Tran and Cavanagh (1984) there is a specifically located structural weakness in impermeable seeds, which is the focus for breakdown of hard seeds by natural agents. In Papillionaceae legumes, the point of weakness is located beneath the lens or strophiole (Probert 1992). Chemical scarification is widely used to overcome the strength of seed covering structures in many species: Lupinus havardy (Mackay et al. 1995), Pistacia mutica (Caloggero and Parera 2000), Prosopis cineraria, Leucaena leucocephala, Acacia nilotica and Acacia tortilis (Sacheti and AlRawahy 1998) and Rubus sp. (Peacock and Hummer 1996).

The objectives of this experiment were to determine the factors that influence seed germination in A. subterranea and to evaluate the effects of chemical and mechanical scarification on germination and emergence.

\section{Materials and Methods}

Seed material

The seeds of A. subterranea were collected in 3 different areas (Los Morrillos, Agua Negra, and San Guillermo) $32^{\circ} 17^{\prime} \mathrm{S} 69^{\circ}$ 
42 'W of the Andean Cordillera in San Juan, Argentina, in March 1999. The altitude of the collection sites varies between 2,500 to $3,500 \mathrm{~m}$. The seeds from the 3 collection areas were mixed, shelled and placed in hermetically sealed containers at room temperature $\left(25^{\circ} \mathrm{C}\right)$ until the seed scarifications treatments were applied. The average weight of 1,000 seeds was $2.62 \mathrm{~g}$ and the moisture content was $12 \%$ (ISTA 1985).

\section{Seed treatments.}

Chemical scarification.

The seeds $(5,000)$ were soaked in $50 \mathrm{ml}$ of concentrated sulfuric acid ( $36 \mathrm{~N})$ for 1 , 2 , or 3 minutes. After treatment, seeds were rinsed several times with tap water and dried at room temperature $\left(25^{\circ} \mathrm{C}\right)$.

\section{Mechanical scarification.}

The seed coat on one side of the seed was perforated with a needle avoiding cotyledon damage.

\section{Measurements}

Water uptake and leakage conductivity. Four replications of $26 \mathrm{mg}$ of seed $(\sim 100$ seeds) were soaked in $30 \mathrm{ml}$ of distilled water at $20^{\circ} \mathrm{C}$. The weight of imbibed seed was recorded at $10,20,40,60$, or 90 minutes. Water uptake was expressed as the percentage increase over initial fresh weight. The conductivity of the leachate was measured with a conductivity meter (Oacton Instruments, Vernon Hills, Ill) at the same temperature and intervals and referred as $\mu \mathrm{S} \mathrm{m}^{-1} \mathrm{~g}^{-1}$ of seed.

\section{Germination test.}

Four replicates of 25 seeds of each treatment were sowed in a petri dish with germination paper (Munktell filter 1700, Sweden) moistened with distilled water and incubated at $5,10,15,20,25$, or $30^{\circ}$ C. Additional seeds, sowed in a Petri dish, were placed in growth chambers providing 2 day/night temperature 16 hours/8 hours cycles $\left(14^{\circ} \mathrm{C} /-2^{\circ} \mathrm{C}\right)$ and $\left(19^{\circ} \mathrm{C} /-0.5^{\circ}\right.$ $\mathrm{C})$ to simulate the average maximum and minimum temperatures in January at the collection sites. Light was coincident with the high temperature period of each cycle and supplied by both fluorescent and incandescent lamps at a photosynthetic photon flux density of $420 \mu \mathrm{mol} \mathrm{m} \mathrm{sec}^{-1}$. Seed was considered germinated when the radicle length exceeded $2 \mathrm{~mm}$. Germinated seeds were counted every 24 hours and removed. The experiment was concluded after 12 days.

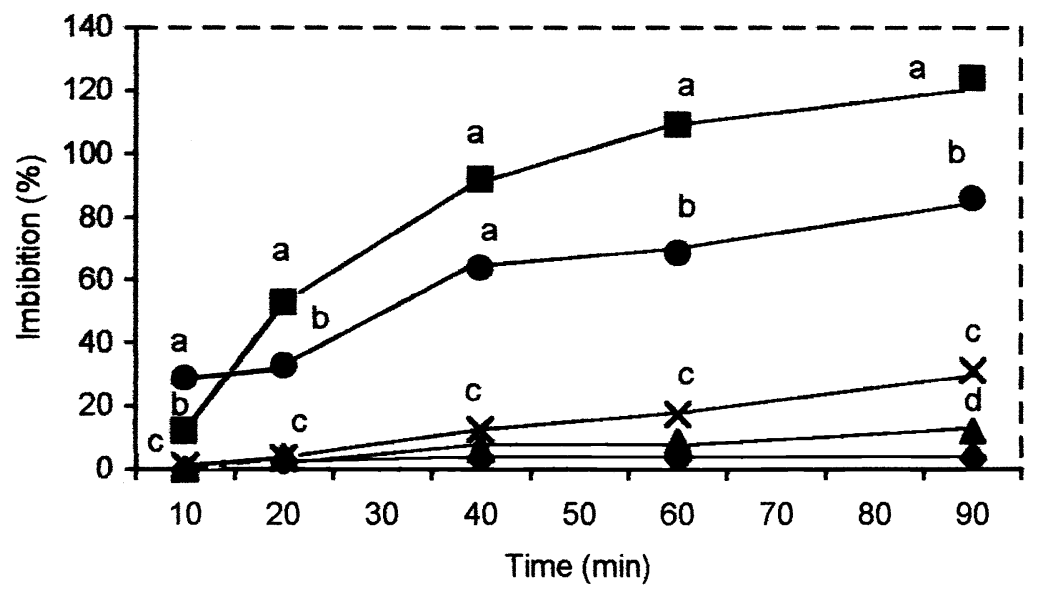

$$
\begin{aligned}
& \text { Control } \\
& - \text { Chemical }(1 \mathrm{~min}) \\
& \text { Chemical }(5 \mathrm{~min})
\end{aligned}
$$

Fig. 1. Seed imbibition (percentage increase over initial fresh weight) of control and scarified seeds incubated at $20^{\circ} \mathrm{C}$. Means followed by the same letter are not significantly different at $P=0.05$ using least significant difference test (LSD).

\section{Emergence test}

Four replications of 45 seeds were sowed into 250 cell tray $\left(16 \mathrm{~cm}^{3}\right.$ cell $)$ filled with a commercial substrate (Fitotec, San Juan, Argentina) composed of sphagnum peat, horticultural vermiculite and perlite, and incubated at the same 2 day-night cycles used for the germination tests. Treatments were also tested simultaneously using perlite as the substrate for a day night temperature 16 hours
$/ 8$ hours $\left(19^{\circ} \mathrm{C} /-0.5^{\circ} \mathrm{C}\right)$ cycle. Emerged seeds were counted every 24 hours. The experiment was concluded after 12 days when no further seedlings had emerged.

\section{Experimental design and statistical analysis.}

All the experiments were conducted as a randomized complete block design with 4 replications. All variables were subjected to analyses of variance using PROC
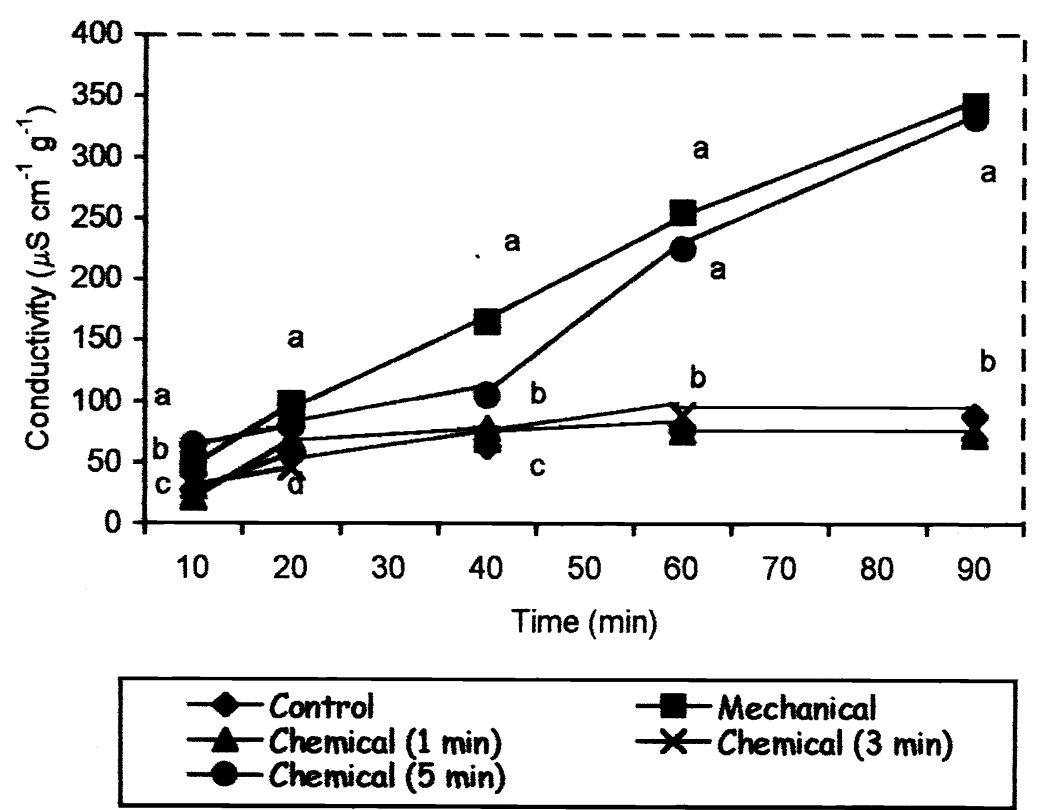

Fig. 2. Seed leakage conductivity $\left(\mu \mathrm{S} \mathrm{cm}^{-1} \mathrm{~g}^{-1}\right)$ of control and scarified seeds incubated at $20^{\circ}$ C. Means followed by the same letter are not significantly different at $P=0.05$ using least significant difference test (LSD). 
Table 1. Effect of temperature and treatments on petri dish germination, emergence rate index (ERI), Maguire's equation (MG), and mean time germination (MTG) of $A$. subterranea seeds.

\begin{tabular}{|c|c|c|c|c|}
\hline & Germination & ERI & MG & MTG \\
\hline & $\%$ & & & \\
\hline Treatment (Tr) & $* *$ & $* *$ & $* *$ & $* *$ \\
\hline Temperature $(\mathrm{T})$ & $* *$ & $* *$ & $* *$ & $* *$ \\
\hline $\operatorname{Tr} \times \mathrm{T}$ & $\mathrm{ns}$ & ns & ns & ns \\
\hline \multicolumn{5}{|l|}{ Treatments } \\
\hline Control & $37.0 \mathrm{~d}$ & $1.73 \mathrm{~d}$ & $1.78 \mathrm{~d}$ & $6.06 \mathrm{a}$ \\
\hline Mechanical scarification & $93.6 \mathrm{a}$ & $7.33 \mathrm{a}$ & $12.08 \mathrm{a}$ & $3.19 \mathrm{c}$ \\
\hline Chemical scarification (1 min) & $76.1 \mathrm{c}$ & $4.73 \mathrm{c}$ & $6.38 \mathrm{c}$ & $4.99 \mathrm{~b}$ \\
\hline Chemical scarification (3 min) & $85.2 \mathrm{~b}$ & $6.64 \mathrm{~b}$ & $11.13 \mathrm{a}$ & $3.19 \mathrm{c}$ \\
\hline Chemical scarification (5 $\mathrm{min})$ & $90.0 \mathrm{ab}$ & $6.21 \mathrm{~b}$ & $8.10 \mathrm{~b}$ & $3.85 \mathrm{c}$ \\
\hline \multicolumn{5}{|l|}{ Temperature $\left({ }^{\circ} \mathrm{C}\right)$} \\
\hline 5 & $63.5 \mathrm{~b}$ & $3.11 \mathrm{c}$ & $2.98 \mathrm{~d}$ & $5.95 \mathrm{a}$ \\
\hline 10 & $79.0 \mathrm{a}$ & $6.09 \mathrm{ab}$ & $9.02 \mathrm{~b}$ & $3.84 \mathrm{cb}$ \\
\hline 15 & $75.6 \mathrm{a}$ & $5.47 \mathrm{cb}$ & $8.90 \mathrm{bc}$ & $4.05 \mathrm{c}$ \\
\hline 20 & $83.1 \mathrm{a}$ & $6.56 \mathrm{a}$ & $12.00 \mathrm{a}$ & $3.05 \mathrm{c}$ \\
\hline 25 & $78.6 \mathrm{a}$ & $5.23 c$ & $7.18 \mathrm{c}$ & $4.59 \mathrm{~b}$ \\
\hline 30 & $78.6 \mathrm{a}$ & $5.50 \mathrm{cb}$ & $7.08 \mathrm{c}$ & $4.05 \mathrm{~b}$ \\
\hline Linear & $* *$ & $* *$ & $* *$ & $* *$ \\
\hline Quadratic & $* *$ & $* *$ & $* *$ & $* *$ \\
\hline
\end{tabular}

ns, *,* Non significant or significant at the 0.05 and 0.01 probability levels respectively.

Means followed by the same letter are not significantly different at $\mathrm{P}=0.05$ according LSD test.
ANOVA and PROC GLM of SAS (SAS Institute, Inc., Cary, N.C.). The main effect of temperature was partitioned into linear and quadratic orthogonal contrasts. Means were compared with a least significant difference test (LSD) at $P=0.05$. In each experiment germination percentage, emergence rate index (Shmueli and Goldberg 1971) $\left(E R I=\sum X_{n}(c-n)\right.$, where $X_{n}=$ number of germinated seeds counted in day $n$; $\mathrm{c}=$ number of days from sowing until germination ended; $\mathrm{n}=$ day on which counts are made, expressed as the number of days after sowing), mean time to germination (Bewley and Black 1986) (MTG= $\sum($ t.n)/ $\sum \mathrm{n}$, where $\mathrm{t}=$ time in days, starting from day 0 , the day of sowing and $n=$ number of seeds completing germination on day $t$ ) and Maguire's equation (Maguire 1962) $\mathrm{n} 1, \mathrm{n} 2 \ldots, \mathrm{n} 12=$ number of germinated seeds at times $\mathrm{t} 1, \mathrm{t} 2, \ldots, \mathrm{t} 12$ in days) were calculated. All percentage data were arc sine transformed previous to the analysis.

\section{Results and Discussion}

The water uptake and electrical conductivity of the leachate were significantly modified by the treatments. Higher leakage conductivity and imbibition were observed with mechanical scarification and the longer chemical scarification time (Fig. 1 and 2). As soaking time increased the difference between these 2 treatments and the others increased. Conductivity and water uptake were always lowest for the control seeds. Weight of control seeds and those chemically scarified for 1 and 3 minutes increased $20 \%$ or less after 90 min$(\mathrm{MG}=\mathrm{n} 1 / \mathrm{t} 1+\mathrm{n} 2 / \mathrm{t} 2+\ldots .+\mathrm{n} 12 / \mathrm{t} 12 ;$ where utes incubation, whereas weight of mechanically scarified seeds and those chemically scarified for 5 minutes increased $120 \%$ and $90 \%$. The data indicate that seeds of $A$. subterranea have an impermeable seed coat which restricts water uptake and also shows the efficiency of the scarification treatments to overcome seed coat impermeability.

Scarification of the seed significantly improved the germination percentage and germination rate expressed as Emergence Rate Index, Maguire's equation or Mean
Time Germination compared to control, at all incubation temperatures (Table 1). The results confirm the efficacy of sulfuric acid to increase germination in hard leguminous seeds reported by other authors (Masamba 1994, Mackay et al. 1995, Teketay 1996). Increasing the time of chemical scarification improved germination and its velocity, however there were no significant differences between mechanical scarification and the 5 minutes chemical scarification.

Scarified seeds germinated over a wide range of constant temperatures (Table 1). There was a significant linear and quadratic response of the percentage and velocity of germination to temperature, where the higher germination, emergence rate index and Maguire's equation were reached at $20^{\circ} \mathrm{C}$.

When treatments were evaluated at 2 different temperature cycles in a petri dish test, percentage and rate of germination were significantly greater in a warmer cycle (Table 2). The 5 and 3 minutes chemical scarification and mechanical scarification resulted in significantly higher germination percentage compared to the control and 1 minute chemical scarification (Table 2).

Rate and amount of emergence changed dramatically when the seeds were sowed in a commercial substrate at the same temperature cycles. The temperature significantly modified the Emergence Rate Index, Maguire's equation and Mean Time Germination (Table 3). The final germination percentage was significantly higher with 5 and 3 minutes acid scarification compared to the mechanical scarification, con-

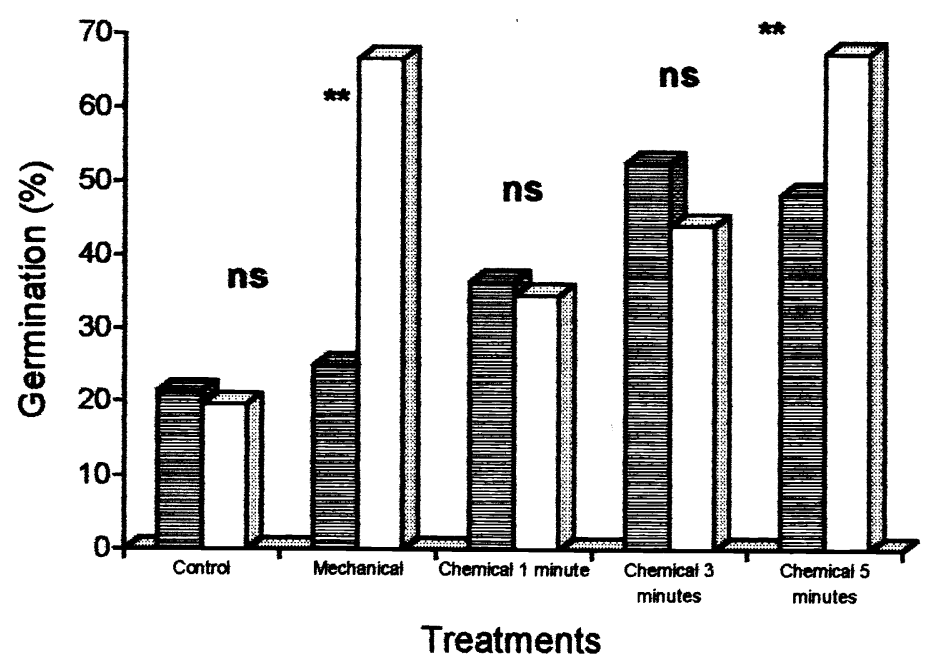

\section{O Commercial DPerlite}

Fig. 3. Effects of the substrate on emergence of $A$. subterranea scarified seeds and control, incubated at a day night temperature 16 hours/8hours $\left(19^{\circ} \mathrm{C} /-0.5^{\circ} \mathrm{C}\right)$ cycle. ns, *,** Non significant or significant at the 0.05 and 0.01 probability levels respectively. 
Table 2. Effects of presowing treatments on germination percentage, emergence rate index (ERI), Maguire's equation (MG), and mean time germination (MTG) of $A$. subterranea seeds incubated in a petri dish at 2 different temperature regimes.

\begin{tabular}{lcccc}
\hline \hline & Germination & ERI & MG & MTG \\
\hline & $\%$ & & $* *$ & $* *$ \\
Treatment (Tr) & $* *$ & $* *$ & $* *$ & ns \\
Temperature (T) & $* *$ & $\mathrm{~ns}$ & $\mathrm{~ns}$ & \\
Tr x T & & & & \\
Treatments & $35.0 \mathrm{c}$ & $1.42 \mathrm{~d}$ & $1.35 \mathrm{~d}$ & $8.08 \mathrm{a}$ \\
Control & $91.0 \mathrm{a}$ & $7.95 \mathrm{a}$ & $9.83 \mathrm{a}$ & $3.26 \mathrm{~cd}$ \\
Mechanical scarification & $65.5 \mathrm{~b}$ & $3.80 \mathrm{c}$ & $3.58 \mathrm{c}$ & $6.17 \mathrm{~b}$ \\
Chemical scarification $(1 \mathrm{~min})$ & $82.0 \mathrm{a}$ & $6.37 \mathrm{~b}$ & $6.79 \mathrm{~b}$ & $4.21 \mathrm{c}$ \\
Chemical scarification $(3 \mathrm{~min})$ & $85.5 \mathrm{a}$ & $7.71 \mathrm{a}$ & $10.52 \mathrm{a}$ & $2.97 \mathrm{~d}$ \\
Chemical scarification $(5 \mathrm{~min})$ & & & & \\
& & & & \\
Temperature $\left({ }^{\circ} \mathrm{C}\right)$ & 80.0 & 6.07 & 5.35 & 4.78 \\
$14 /-2$ & 63.0 & 4.83 & 5.48 & 5.10 \\
$19 /-0.5$ & & & & \\
\hline
\end{tabular}

$\mathrm{ns},{ }^{*}, * *$ Non significant or significant at the 0.05 and 0.01 probability levels respectively.

Means followed by the same letter are not significantly different at $\mathrm{P}=0.05$ according LSD test.

trol and 1 minute chemical scarification. Similar responses were observed in the calculated germination rate indexes. Evidently, the substrate has a strong effect on the germination of mechanically scarified seeds.

To determine the effect of the substrate on the emergence percentage, all the treatments were evaluated using the cycle 2 temperature with perlite as substrate. The results showed that the emergence percentage of mechanical scarification and chemical scarification for 5 minutes were significantly higher with perlite as the substrate (Fig. 3).

Woodstock (1988) reported that microbial attack stimulated by enhanced leaching from damaged cotyledons may act to further reduce field emergence. In our experiment the greatest seed leaching was observed following mechanical scarification and the most severe chemical scarification treatment. These treatments were severely affected by the use of non sterile germination conditions.

Table 3. Effects of presowing treatments on emergence percentage, emergence rate index (ERI), Maguire's equation (MG) and mean time germination (MTG) of $A$. subterranea seeds incubated at 2 different temperature regimes using commercial substrate.

\begin{tabular}{|c|c|c|c|c|}
\hline & Emergence & ERI & MG & MTG \\
\hline & $\%$ & & & \\
\hline Treatment (Tr) & $* *$ & $* *$ & $* *$ & $* *$ \\
\hline Temperature (T) & ns & $* *$ & $* *$ & $* *$ \\
\hline $\operatorname{Tr} \times \mathrm{T}$ & ns & ns & ns & ns \\
\hline \multicolumn{5}{|l|}{ Treatments } \\
\hline Control & $16.9 \mathrm{c}$ & $2.03 \mathrm{c}$ & $1.29 \mathrm{c}$ & $9.33 \mathrm{a}$ \\
\hline Mechanical scarification & $23.2 \mathrm{c}$ & $3.46 \mathrm{bc}$ & $2.59 \mathrm{bc}$ & $5.38 \mathrm{c}$ \\
\hline Chemical scarification (1 min) & $37.5 \mathrm{~b}$ & $4.65 \mathrm{~b}$ & $3.21 \mathrm{~b}$ & $7.79 \mathrm{ab}$ \\
\hline Chemical scarification ( $3 \mathrm{~min}$ ) & $51.5 \mathrm{a}$ & $6.79 \mathrm{a}$ & $5.22 \mathrm{a}$ & $7.20 \mathrm{bc}$ \\
\hline Chemical scarification (5 min) & $54.2 \mathrm{a}$ & $7.71 \mathrm{a}$ & $5.27 \mathrm{a}$ & $6.51 \mathrm{bc}$ \\
\hline \multicolumn{5}{|l|}{ Temperature $\left({ }^{\circ} \mathrm{C}\right)$} \\
\hline $14 /-2$ & 36.7 & 6.52 & 4.46 & 4.54 \\
\hline $19 /-0.5$ & 36.7 & 3.34 & 2.58 & 9.94 \\
\hline
\end{tabular}

$\mathrm{ns}, *, * *$ Non significant or significant at the 0.05 and 0.01 probability levels respectively.

Means followed by the same letter are not significantly different at $\mathrm{P}=0.05$ according LSD test.

\section{Literature Cited}

Bewley, J.D. and M. Black. 1986. Seeds physiology of development and germination. Plenum Press, New York, N.Y.

Bradbeer, J.W. 1988. Seed dormancy and germination. Chapman and Hall, New York, N.Y.

Burkart, A. 1967. Sinopsis del género sudamericano de Leguminosas Adesmia DC (In Spanish). Darwiniana 14: 463-568.

Cajal, J.L. 1983. Estructura social y área de acción del guanaco (Lama guanicoe) en la reserva de San Guillermo (Provincia de San Juan). Censo de camélidos y comportamiento del guanaco en la reserva de San Guillermo (In Spanish). SUBCyT. Buenos Aires, Argentina.

Caloggero, S. and C.A. Parera. 2000. Improved germination and emergence of Pistacia mutica by presowing chemical scarification. Seed Sci. and Tech., 28: 253-260.

Egley, G.H. 1989. Water impermeable seed coverings as barriers to germination. In: R. B. Taylorson (ed), Recent advances in the development and germination of seeds. Plenum Press, New York. N.Y.

Gutterman, Y. 1993. Seed germination in desert plants. Springer-Verlag, Berlin.

ISTA. 1985. International rules for seed testing. Seed Sci. and Tech. 13:338-341.

Kiesling, R. 1994. Flora de San Juan, Argentina. (In Spanish). Vazques-Mazzini. Buenos Aires. Bs.As.

Mackay, W.A., T.D. Davis, and, D. Sankhla. 1995. Influence of scarification and temperature treatments on seed germination of Lupinus havardii. Seed Sci. and Tech. 23: 815-821.

Maguire, J.D. 1962. Speed of germination-aid in selection and evaluation for seedling emergence and vigor. Crop Sci. 2:176-177.

Masamba, C. 1994. Presowing seed treatments on four African Acacia species: Appropriate technology for use in forestry for rural development. Forest Ecol. Manage. 64:105-109.

Peacock, D. and K.M. Hummer. 1996. Pregermination studies with liquid nitrogen and sulfuric acid on several Rubus species. HortSci. $31: 238-239$.

Pelliza-Sbriller, A., N. Bonino, G. Bonvissuto, and J. Amaya. 1985. Composición botánica de la dieta de herbívoros silvestres y domésticos en el área Pilcaneyeu (Río Negro). (In Spanish). IDIA: 429-432:63-73.

Probert, R.J. 1992. The role of temperature in germination ecophysiology. In: M. Fenner (ed), Seeds: the ecology of regeneration in plant communities. CAB International. UK.

Sacheti U. and S. H. Al-Rawahy. 1998. The effects of various pretreatments on the germination of important leguminous shrub-tree species of the Sultanate of Oman. Seed Sci. and Tech. 26: 691-699.

Shmueli, M. and D. Goldberg. 1971. Emergence, early growth and salinity of five vegetable crops germinated by sprinkle and trickle irrigation in arid zones. HortSci. 6: 563-565.

Teketay, D. 1996. Germination ecology of twelve indigenous and exotic multipurpose leguminous species from Ethiopia. Forest Ecol. Manage. 80: 209-223.

Tran, V.N. and A. K. Cavanagh. 1984. Structural aspects of dormancy. In: D.R Murray (ed.), Seed Physiology, Vol II. Germination and reserve mobilization. Academic Press, Sydney, New South Wales, Australia.

Woodstock, L.W. 1988. Seed imbibition: A critical period for successful germination. J. Seed Tech. 12:1-15. 


\title{
Germination of seeds of big and bottlebrush squirreltail
}

\author{
JAMES A. YOUNG,* CHARLIE D. CLEMENTS, AND TOM JONES
}

Authors are Range Scientists, USDA-ARS, 920 Valley Road, Reno, Nev. 89512 and Research Geneticist, USDA-ARS, Forage and Range Research Laboratory, Utah State University, Logan, Utah 84322-6300. *E-mail for corresponding author: jayoung@ unr.nevada.edu

Abstract

Bottlebrush squirreltail [Elymus elymoides (Raf.) Swezey] and big squirreltail [E. multisetus (J. G. Smith) Burtt Davy] are short-lived perennial bunchgrasses found on rangelands from the Pacific Coast to the Great Plains and from Canada to Mexico. They are highly variable species with several subspecies described for bottlebrush squirreltail. In many rangeland communities, bottlebrush squirreltail is the transitional dominant native grass in secondary successional communities. There is considerable interest in using squirreltail species in rangeland restoration seedings, but problems with seed collection (disarticulating rachis) have kept seed prices very high. Recently, grass geneticists have begun to develop lines of squirreltail for release as pre-varietal germplasm. Our purpose was to compare the germination at a wide range of constant or alternating temperatures of squirreltail seeds from developmental lines and material collected from native stands. Big and bottlebrush squirreltail seeds (caryopses) germinated over a wide range of temperatures. Seeds of bottlebrush squirreltail produced from the same stand in 3 different years had remarkably similar germination temperature profiles. The greatest variation in germination among accessions occurred at very cold and cold categories of seedbed temperatures. These differences may be very significant in the establishment of seedlings in the field. There was no one temperature regime that always supported optimum germination for all of the squirreltail accessions tested. The regimes most frequently supporting optimum germination were $15 / 20$ and $15 / 25^{\circ} \mathrm{C}$. The seeds of big and bottlebrush squirreltail tested do not have the ecological amplitude of seeds of the competitive exotic weed cheatgrass (Bromus tectorum $\mathrm{L}$.), but they come close.

Key Words: Elymus elymoides, Elymus multisetus, incubation temperatures, germination profiles, cheatgrass

For many years range managers knew bottlebrush squirreltail [Elymus elymoides (Raf.) Swezey] by the scientific name of Sitanion hystrix (Nutt.) J. G. Smith. Big squirreltail [E. multisetus (J. G. Smith) Burtt Davy] originally known as S. jubatum J. G. Smith, is a less widely recognized species, and probably often confused with bottlebrush squirreltail (Hitchcock 1950). For a long time it has been recognized that squirreltail plants are closely related to the genus Pseudoroegneria and Elymus (Cronquist et al. 1977). Many natural hybrids have been recognized with squirreltail considered to be one parent (Wilson 1963). The taxonomic reshuffling is a result of vastly improved understanding of the

Manuscript accepted 4 Aug. 2002.
Resumen

"Bottlebrush squirreltail" [Elymus elymoides (Raf.) Swezey] y "Big squirreltail" [E. multisetus (J. G. Smith) Burtt Davy] son zacates amacollados perennes de vida corta que se encuentran en los pastizales, desde la Costa del Pacifico hasta las Grandes Planicies y desde Canadá hasta México. Estas especies son altamente variables con varias subespecies descritas para "Bottlebrush squirreltail". En muchas comunidades de pastizal, en sucesión secundaria, el "Bottlebrush squirreltail" es el zacate nativo transicional dominate. Hay un considerable interés en usar especies de "Squirreltail" en siembras para restaurar pastizales, pero problemas con la colección de semilla (desarticulación del raquis) han mantenido los precios de la semilla muy altos. Recientemente los genetistas de pastos han iniciado el desarrollo de líneas de "Squirreltail" para liberarlas como germoplasma pre-varietal. Nuestro propósito fue comparar la germinación de semillas de las líneas de "Squirreltail" en desarrollo y material colectado de poblaciones nativas bajo un amplio rango de temperaturas constantes o alternadas. Las semillas (cariposides) de "Big squirreltail" y "Bottlebrush squirreltail" germinaron en un amplio rango de temperaturas. Semillas de "Bottlebrush squirreltail" producidas en la misma población, pero en tres diferentes años, tuvieron perfiles de temperatura de germinación remarcablemente similares. La mayor variación en germinación entre las accesiones evaluadas ocurrió en las categorías de temperatura de la cama de siembra de frias y muy fria. Estas diferencias pueden ser muy significativas en el establecimiento de plántulas en el campo. No hubo un régimen de temperatura que mantuviera siempre la germinación óptima para todas las accesiones de "Squirreltail" evaluadas. Los regímenes que más frecuentemente mantuvieron la geminación óptima fueron 15/20 y $15 / 25^{\circ} \mathrm{C}$. Las semillas evaluadas de "Big squirreltail" $y$ "Bottlebrush squirreltail" no tienen la amplitud ecológica de las semillas de la maleza exótica "Cheatgrass" (Bromus tectorum L.), sin embargo ellas están muy cerca.

genetics of the grass tribe Triticeae and the introduction of molecular biochemical techniques to determine affinities (Barkworth 1993).

In the Intermountain Area, temperatures for plant growth and soil moisture to support such growth are nearly completely out of phase (Evans et al. 1970). Moisture occurs during the cold winter months and the summers are nearly dry. Plants that germinate at very cold seedbed temperatures have the opportunity to establish before the late spring and summer drought. Cheatgrass (Bromus tectorum L.) closes plant communities to the establishment of perennial grass seedlings through competition for soil moisture (Evans et al. 1970). This competitive advantage is enhanced by 
the inherent potential to germinate at very low seedbed temperatures (Young and Evans 1982).

In a previous study we developed germination temperature profiles for seeds of bottlebrush squirreltail collected from native stands (Young and Evans 1977). In that study seeds were collected from the same stand for 3 years over a 4 year period. The average germination of seeds of this material was published, but the profiles for individual years were not published.

Our purpose was to compare the germination temperature profiles from this previous work with one developed for a native stand collection that we have successfully used to establish stands on harsh sites in Nevada, and with developmental lines used in the grass improvement program of the third author. All of these accessions of squirreltail are compared to cheatgrass.

\section{Materials and Methods}

Seeds of bottlebrush squirreltail were collected in 1972, 1974, and 1975 from a stand located at Medell Flat $30 \mathrm{~km}$ north of Reno, Nev. (Lat. 39 38', Long. 140 ${ }^{\circ}$ $\left.19^{\prime}\right)$. This collection is considered to be Elymus elymoides ssp. elymoides (Raf.) Swezey. There was no seed production in 1973. The seeds from several hundred plants growing in a previously burned big sagebrush (Artemisia tridentata Nutt.) site were collected. The seeds were threshed by hand, cleaned, and stored at room temperature for 90 days before testing. A second source from native stands was collected for us in White Pine County, Nev. (Lat. $39^{\circ} 10^{\prime}$, Long. $114^{\circ} 15^{\prime}$ ) in 1999 by a commercial seed dealer. This collection is also considered to be E. elymoides ssp. elymoides. We sampled from a $50 \mathrm{~kg}$ seed lot to obtain the seeds for laboratory testing. This collection, identified as White Pine, has been successfully seeded at several locations in the northern Great Basin (unpublished research, USDA, ARS, Reno, Nev.).

The Forage and Range Research Laboratory, USDA, ARS, Logan, Utah received 36 accessions of squirreltail in 1993 from the USDA, National Resource Conservation Service (NRCS), Plant Material Center, Aberdeen, Ida. This material had been collected from California, Colorado, Idaho, Montana, Nevada, Oregon, Utah, and Washington. The material was planted at the Greenville Farm experimental site north of Logan, Utah (Lat. $41^{\circ} 54^{\prime}$, Long. $111^{\circ} 50^{\prime}$ ). The squirreltail accessions were evaluated for seed production and heading date. The accession with the highest seed yield and weight was Sand Hollow (Lat. $43^{\circ} 51^{\prime}$, Long. $116^{\circ} 51^{\prime}$ ) a big squirreltail (Jones et al. 1998). Sand Hollow has been released as a pre-variety germplasm (natural tract).

A second accession of big squirreltail (Dietrich) was collected near Dietrich, Ida. (Lat. 42 ${ }^{\circ}$ 54', Long. $114^{\circ} 19^{\prime}$ ) in 1995. It has been tested in experiments located at the Greenville experimental site and it was from these plantings that we obtained the seed for laboratory testing. This accession is not proposed for release at this time. A bottlebrush squirreltail accession (Fish Creek) was collected near Carey, Ida. (Lat.43 ${ }^{\circ} 21^{\prime}$, Long. $113^{\circ} 52^{\prime}$ ) in 1995 and grown in experiments at Greenville from which we obtained seed for testing. It is proposed for release as a pre-variety germplasm.

In all experiments 4 replications of 25 seeds each were used in a randomized block design. Seeds were placed on top of non-toxic commercial germination paper in closed Petri dishes and kept wet with tap water. Germination trials were conducted in the dark. Incidental light was received during initial wetting and germination counts. Seeds were considered germinated when the radical emerged $1 \mathrm{~mm}$. Germination counts were made after 1, 2, and 4 weeks. Constant incubation temperatures were 0,2 , and $5^{\circ} \mathrm{C}$ and at 5 degree increments through $40^{\circ} \mathrm{C}$. Alternating regimes included 16 hours at each constant temperature, plus 8 hours at each possible higher temperature per 24 hours. For example, $35 \mathrm{C}$ alternated with $40^{\circ} \mathrm{C}$ only, while $0^{\circ} \mathrm{C}$ alternated with $2,5,10$, $15,20,25,30,35$, and $40^{\circ} \mathrm{C}$. This made a total of 55 constant and alternating temperature regimes (Young et al. 1991).

The germination responses of the accessions of squirreltail accessions were compared using the following seedbed temperature regime definitions (Evans et al. 1982, Young and Evans 1982):

a. Very cold: $0 / 0$ (constant $\left.0^{\circ} \mathrm{C}\right), 0 / 2\left(0^{\circ}\right.$ $\mathrm{C}$ for 16 hours and $2^{\circ} \mathrm{C}$ for 8 hours in each 24 hours), $0 / 5$ and $2 / 2^{\circ} \mathrm{C}$.

b. Cold: $0 / 10,0 / 15,2 / 5,2 / 10,2 / 15,5 / 5$, and $5 / 10^{\circ} \mathrm{C}$.

c. Cold fluctuating: $0 / 20$ through $0 / 40^{\circ} \mathrm{C}$ and $2 / 20$ through $2 / 40^{\circ} \mathrm{C}$.

d. Fluctuating: $5 / 35$ through $5 / 40^{\circ} \mathrm{C}$, $10 / 35,10 / 40$, and $15 / 40^{\circ} \mathrm{C}$.

e. Moderate: $5 / 20$ through $5 / 30,10 / 10$ through $10 / 30^{\circ} \mathrm{C}, 15 / 15$ through $15 / 35^{\circ} \mathrm{C}, 20 / 20$ through $30 / 35^{\circ} \mathrm{C}$, and $25 / 25$ through $25 / 30^{\circ} \mathrm{C}$

f. Warm: $20 / 40,25 / 35$, and $25 / 40^{\circ} \mathrm{C}$, $30 / 30$ through $30 / 40^{\circ} \mathrm{C}, 35 / 35,35 / 40$, and $40 / 40^{\circ} \mathrm{C}$.

The temperature categories reflect germination environments of field seedbeds based on several years of monitoring in the Great Basin (Evans et al. 1970, Evans and Young 1970, 1972).

Data from each base temperature and its alternating temperature regimes were used

Table 1. Germination parameters calculated from quadratic response surfaces (Young and Evans 1982).

\begin{tabular}{|c|c|c|}
\hline Calculated parameter & Derived parameter & Purpose \\
\hline \multicolumn{3}{|l|}{ Calculated within profile } \\
\hline Mean germination & $\underset{55}{\text { Sum }}$ & Gross comparison of profiles \\
\hline Percentage of regimes with germination & $\frac{\text { Number with germination }}{55}$ & Indication of breath of germination response \\
\hline $\begin{array}{l}\text { Percentage of regimes with optimum } \\
\text { germination }\end{array}$ & $\begin{array}{l}\text { Number of regimes with germination no less than } \\
\text { maximum observed minus confidence interval }\end{array}$ & $\begin{array}{l}\text { Indication of breath of temperatures that } \\
\text { Support optimum germination }\end{array}$ \\
\hline Mean of optima & $\frac{\text { Sum of optima }}{\text { Number of optima regimes }}$ & $\begin{array}{l}\text { Provides measure of potential germination at } \\
\text { adapted temperatures }\end{array}$ \\
\hline Maximum germination & Highest observed germination & Indication of potential viability \\
\hline $\begin{array}{l}\text { Calculated among germination profiles } \\
\text { Frequency of optima }\end{array}$ & $\frac{\text { Times temperature regime supports optima }}{\text { Total number of profiles }}$ & $\begin{array}{l}\text { Provides an estimate of optimum temperatures } \\
\text { For germination with statistical precision }\end{array}$ \\
\hline
\end{tabular}


Table 2. Mean germination \pm one half of the confidence interval at the 0.01 level of probability for seeds of the Medell Flat, Nevada, 1972 accession of bottlebrush squirreltail. Seeds incubated for 4 weeks at constant or alternating temperatures from 0 through $40^{\circ} \mathrm{C}^{1}$

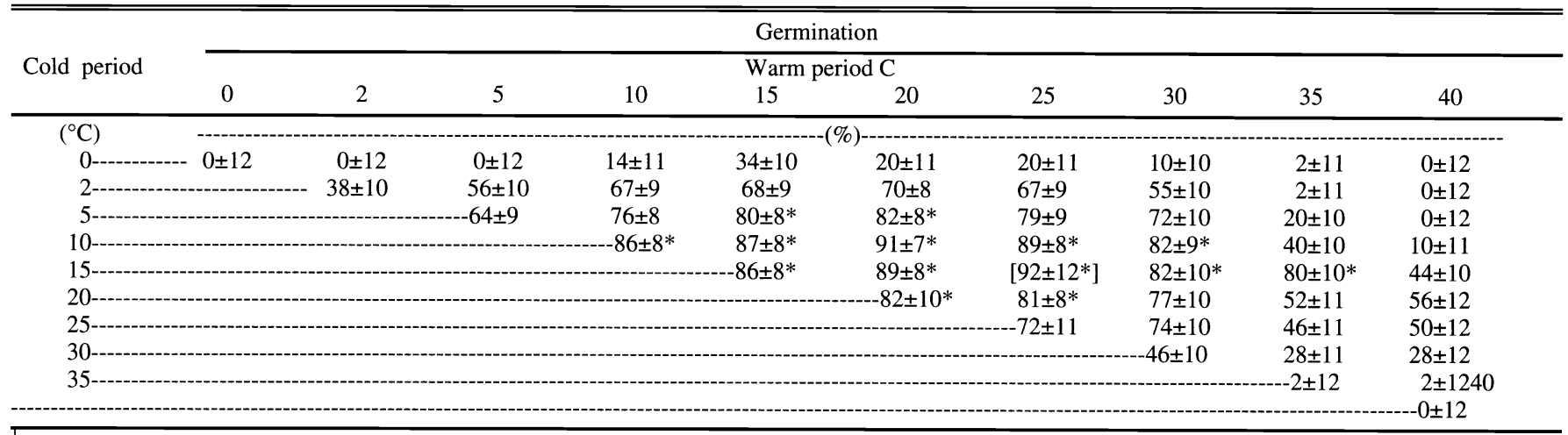

* Indicates temperature regimes with optimum germination. [ ] Encloses maximum observed germination.

to generate a quadratic response surface with estimated means and confidence intervals at the $1 \%$ level of probability (Young et al. 1980, Evans et al. 1982, Palmquist et al. 1987). A number of germination parameters were calculated from the quadratic response surfaces (Table 1) (Young and Evans 1982). These germination parameters were individually subjected to analysis of variance and the means separated by Duncan's Multiple Range Test.

\section{Results and Discussion}

A germination quadratic response surface is provided as an example of the basic data set for bottlebrush squirreltail seeds (Table 2). Germination is estimated with a confidence interval at the 0.01 level of probability for each of the 55 temperatures tested. Temperature regimes supporting optimum germination (defined in Table 1), are marked. The value of this data set is it provides an estimate of the variability that was observed in germination response for a given population of squirreltail seeds over 3 years of production. The 3 years of seed production were remarkably uniform in virtually every parameter examined (Table 3). Mean germination varied among years by only $3 \%$. Temperature regimes with some germination did not vary among years. This is an important parameter because it is an indication of the extremes at which some level of germination can be expected. In the Intermountain Area where precipitation is almost completely out of phase with temperatures for plant growth (Evans et al. 1970), germination of $38 \pm 10 \%$ at a constant $2^{\circ} \mathrm{C}$ (Table 2) may be significant biologically despite that level of germination being a long way from the maximum of $92 \pm 12 \%$ germination observed for that collection of bottle- brush squirreltail seeds. Maximum germination was observed at temperature regimes of $10 / 20\left(10^{\circ} \mathrm{C}\right.$ for 16 hours and 20 for 8 hours in each 24 hour period), $10 / 25,15 / 20$, and $15 / 25^{\circ} \mathrm{C}$. The maximum germination was over $90 \%$ for all 3 years. For a seed collected in the wilds, this is an exceptional level of viability (Young and Evans 1982).

The 3 years of bottlebrush squirreltail production exhibited the greatest variation in germination at the seedbed temperature category of very cold (Table 3 ). Germination only occurred with the seed collected in 1972 and only at a constant $2^{\circ}$ C. For the seeds produced in 1974 and 1975 no germination occurred in this category of seedbed temperatures. These are the temperatures that occur in the interface between snow cover and the mineral soil or in the very early spring in the

Intermountain Area (Evans et al. 1970). In interpreting these results, remember these 3 collections were made over a 4 year period. During the very dry year of 1973 , there was no bottlebrush squirreltail seed production from the Medell Flat stand. Perhaps, the germination response for the 3 years of seed production was so uniform because bottlebrush squirreltail is an extreme ephemeral species. Evidence of how early in the spring bottlebrush squirreltail completes its life cycle is provided by a previous study. In studies conducted at the Medell Flat collection site, we determined that if you were going to lower the apparent carbohydrate reserves of this accession of squirreltail you had to apply defoliation treatments in the very early spring, a month or 6 weeks earlier than for other perennial grasses (Young and Evans 1978).

Table 3. Germination parameters calculated from germination-temperature profiles for 3 collections of bottlebrush squirreltail from the same site (Medell Flat, Nevada) over a 4 year period. There was not sufficient seed production for collection in 1973. Data presented by Young and Evans (1977) as average not by individual years.

\begin{tabular}{lccc}
\hline \hline $\begin{array}{l}\text { Germination } \\
\text { parameter }\end{array}$ & \multicolumn{3}{c}{ Year of seed production } \\
\hline Profile mean & 1972 & 1974 & 1975 \\
Regimes with some & 37 & 35 & 34 \\
$\quad$ germination & 87 & 87 & 87 \\
Mean of optima & 85 & 89 & 91 \\
Regimes with optima & 25 & 22 & 26 \\
Maximum germination & 92 & 94 & 96 \\
Regimes with maxima & $15 / 25^{\circ} \mathrm{C}$ & $15 / 20^{\circ} \mathrm{C}$ & $10 \& 15 / 20^{\circ} \mathrm{C}$
\end{tabular}

Seedbed temperature categories

$\begin{array}{lccc}\text { Very cold } & 10 \mathrm{a} & 0 \mathrm{~b} & 0 \mathrm{~b} \\ \text { Cold } & 56 & 51 & 43 \\ \text { Cold fluctuating } & 25 & 24 & 20 \\ \text { Fluctuatin } & 23 & 27 & 33 \\ \text { Warme } & 29 & 29 & 27 \\ \text { Moderat } & 80 & 78 & 81\end{array}$

The only statistical significant difference among the 3 collections was for germination at the very cold category of seedbed temperatures where means followed by the same letter are not significantly different at the 0.01 level of probability 
Table 4. Germination parameters calculated from germination-temperature profiles for all accessions of bottlebrush and big squirreltail and a comparison with a profile for cheatgrass. ${ }^{1}$

\begin{tabular}{|c|c|c|c|c|c|c|}
\hline \multirow{3}{*}{$\begin{array}{l}\text { Germination } \\
\text { parameter }\end{array}$} & \multicolumn{4}{|c|}{ Accession } & \multirow[b]{2}{*}{ Sand } & \multirow{3}{*}{ Cheatgrass $^{3}$} \\
\hline & $\begin{array}{l}\text { Medell }^{2} \\
\text { Flat }\end{array}$ & $\begin{array}{l}\text { White } \\
\text { Pine }\end{array}$ & $\begin{array}{c}\text { Fish } \\
\text { Creek }\end{array}$ & $\begin{array}{l}\text { Deitrich } \\
\text { Hollow }\end{array}$ & & \\
\hline & \multicolumn{3}{|c|}{ Bottlebrush squirreltail } & \multicolumn{2}{|c|}{ Big squirreltail } & \\
\hline Profile mean & $35 \mathrm{bc}$ & $37 \mathrm{bc}$ & $47 b$ & $33 \mathrm{bc}$ & $26 c$ & $73 a$ \\
\hline $\begin{array}{l}\text { Regimes with } \\
\text { germination }\end{array}$ & & & & & & \\
\hline germination & $87 \mathrm{bc}$ & $98 \mathrm{ab}$ & $78 \mathrm{bc}$ & $75 \mathrm{c}$ & $76 \mathrm{c}$ & $100 \mathrm{a}$ \\
\hline Mean of optima & $88 \mathrm{~b}$ & $82 \mathrm{~b}$ & $96 a$ & $85 \mathrm{~b}$ & $78 \mathrm{c}$ & $97 \mathrm{a}$ \\
\hline Regimes with optima & $24 \mathrm{~b}$ & $4 \mathrm{c}$ & $26 \mathrm{~b}$ & $13 \mathrm{c}$ & $7 \mathrm{c}$ & $35 \mathrm{a}$ \\
\hline Maximum germination & 94ab & $85 b$ & $100 \mathrm{a}$ & $93 \mathrm{ab}$ & $84 b$ & $100 \mathrm{~b}$ \\
\hline \multicolumn{7}{|l|}{$\begin{array}{l}\text { Seedbed temperature } \\
\text { categories }\end{array}$} \\
\hline Very cold & $3 \mathrm{c}$ & $18 \mathrm{~b}$ & $0 \mathrm{c}$ & $9 \mathrm{c}$ & $0 \mathrm{c}$ & $37 \mathrm{a}$ \\
\hline Cold & $50 \mathrm{~b}$ & $57 \mathrm{~b}$ & $26 c$ & $12 \mathrm{~d}$ & $6 \mathrm{~d}$ & $72 a$ \\
\hline Cold fluctuating & $23 \mathrm{c}$ & $32 \mathrm{c}$ & $45 \mathrm{~b}$ & $37 \mathrm{~b}$ & $20 \mathrm{c}$ & $89 \mathrm{a}$ \\
\hline Fluctuating & $28 \mathrm{c}$ & $24 \mathrm{c}$ & $43 b$ & $28 \mathrm{c}$ & $29 \mathrm{c}$ & $90 \mathrm{a}$ \\
\hline Warmer & $28 \mathrm{c}$ & $33 \mathrm{c}$ & $76 a$ & $52 \mathrm{~b}$ & $37 \mathrm{c}$ & $57 \mathrm{a}$ \\
\hline Moderate & $80 \mathrm{a}$ & $60 \mathrm{~b}$ & $90 \mathrm{a}$ & $69 \mathrm{~b}$ & $63 \mathrm{~b}$ & $94 a$ \\
\hline
\end{tabular}

Means within rows followed by the same letter are not significantly different at the 0.01 level of probability as determined by Duncan's Multiple Range Test.

${ }^{2}$ Mean of 3 years production from same site.

${ }^{3}$ Cheatgrass data from Young and Evans 1982.

Comparing all the profiles for big and bottlebrush squirreltail (Table 4), reveals the mean profile germination is quite similar with the only significant $(\mathrm{P} \leq 0.01)$ difference between Fish Creek bottlebrush and Sand Hollow big squirreltail. Fish Creek had the highest and Sand Hollow the lowest mean germination observed. The 2 accession of bottlebrush squirreltail seed harvested from native stands had germination at the highest percentage of the 55 temperature regimes tested. Mean optimum germination was above $80 \%$ for all accessions tested except Sand Hollow big squirreltail. The maximum observed germination exceeded $90 \%$ except White Pine bottlebrush and Sand Hollow big squirreltail. The maximum germination for the Fish Creek accession of bottlebrush squirreltail was $100 \%$. This indicates that all of these seed lots contained highly viable seeds with little or no evidence of seed dormancy.

Table 5. Frequency that temperature regimes supported optimum germination for temperaturegermination profiles for accessions of bottlebrush and big squirreltail.

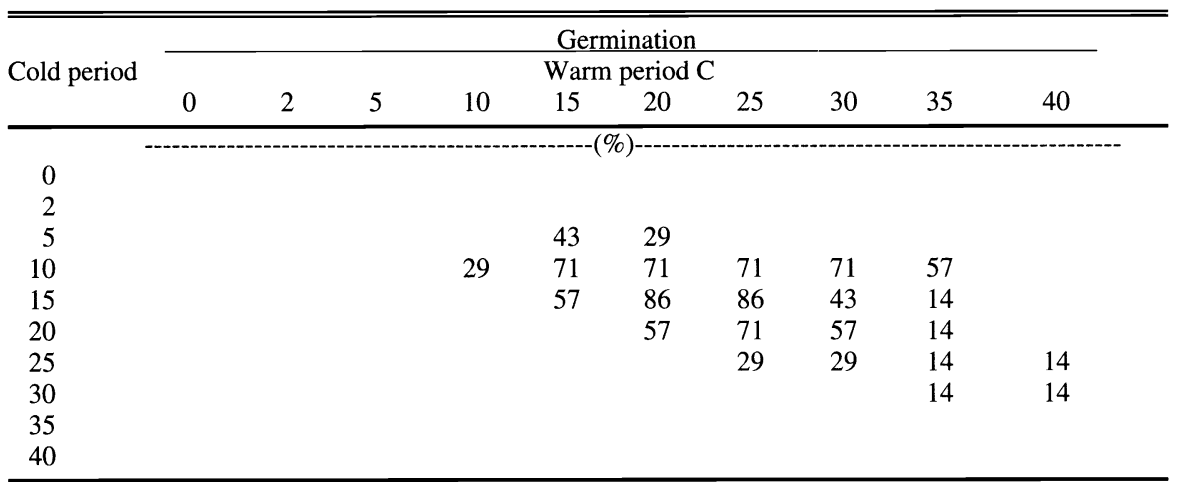

because of higher germination at $0 / 30$ and $2 / 30^{\circ} \mathrm{C}$ regimes than other accessions (data not shown). This is a very wide range of diurnal fluctuation.

The Fish Creek accession had much higher germination at warmer incubation temperatures (Table 4). Perhaps, the higher germination observed at cold fluctuating and fluctuating regimes is not only due to tolerance to wide diurnal fluctuations in incubation temperatures, but also for a tolerance to germinate at higher incubation temperatures. Fish Creek and Medell Flat were clearly the highest germinating accessions at moderate incubation temperatures, which constitute $36 \%$ of the temperature regimes tested.

Cheatgrass is the highly competitive exotic weed that limits the establishment of seedlings of native perennial grasses on Intermountain Area rangelands (Young et al. 1987). At first glance it appears that the germination of cheatgrass seeds is markedly better than for squirreltail seeds in every category (Table 4). There are 3 factors that modify this assumption. In comparison to the germination of other native perennial grasses, the accessions of big and bottlebrush squirreltail are at least distantly close to the same potential as cheatgrass (Young and Evans 1982). The germination potential of seeds of many perennial grasses native to the Intermountain Area is much lower that what we report for big and bottlebrush squirreltail. There is no evidence of dormancy in seeds of squirreltail tested. The squirreltail seeds tested from either native stands or from nurseries, have high levels of viability.

On the negative side in this comparison, is the shear magnitude of cheatgrass germination (Table 4). The cheatgrass profile averaged $73 \%$ germination, while the best squirreltail profile averaged $47 \%$ and the poorest profile averaged $26 \%$. For cheatgrass germination, $35 \%$ of the 55 temperature regimes tested supported germination not lower that the maximum observed $(100 \%)$, minus one half the confidence internal at the 0.01 level of probability. Cheatgrass germinated at all of the 55 temperatures tested. This means germination occurred at a constant $0^{\circ} \mathrm{C}, 40^{\circ} \mathrm{C}$ and $0 / 40^{\circ} \mathrm{C}$. Cheatgrass has much higher germination at very cold and cold categories of seedbed temperatures.

No single temperature regime always supported optimum germination for the seeds of all of the accessions of squirreltail tested (Table 5). The regimes with the highest frequency of optima were 15/20 and $15 / 25^{\circ} \mathrm{C}$. Temperature regimes that 
supported optimum germination at least once ranged from a constant $10^{\circ} \mathrm{C}$ to $25 / 40^{\circ} \mathrm{C}$.

The use of big or bottlebrush squirreltail accessions in restoration seedings is not limited by seed dormancy, lack of viability, or restrictive temperature requirements. Squirreltail seeds do not have the ecological amplitude for germination in comparison to seeds of cheatgrass, but they probably come as close as any native perennial grass in the Intermountain Area. The developmental selection work that so far has been done on accessions of squirreltail has been for seed production and weight, not on the basis of germination characteristics. Obviously, if you seed bottlebrush or big squirreltail accessions on sites infested with cheatgrass, weed control is necessary during site preparation.

\section{Literature Cited}

Barkworth, M. 1993. Elymus. p. 1254. In: J. C. Hickman (ed.) The Jepson Manual. Univer. California Press, Berkeley, Calif.
Cronquist A., A.H. Holmgren, N.H. Holmgren, J.L. Reveal, and P.K. Holmgren. 1977. Intermountain Flora. Vol. 6. Columbia Univer. Pres. New York, N.Y.Evans, R.A. and J.A. Young. 1970. Plant litter and establishment of alien annual species in rangeland communities. Weed Sci. 18:697-703.

Evans, R.A. and J.A. Young. 1972. Microsite requirements for establishment of alien annual species in rangeland communities. Weed Sci. 20:350-356.

Evans, R.A., D.A. Easi, D.N. Book, and J.A. Young. 1982. Quadratic response surface analysis of seed germination trials. Weed Sci. 30:411-416.

Evans, R.A., H.R. Holbo, R.E. Eckert, Jr., and J.A. Young. 1970. Functional environment of downy brome communities in relation to weed control and revegetation. Weed Sci. 18:154-162.

Hitchcock, A.S. 1950. Manual of grasses of the United States. Misc. Publ. 200. USDA, Washington, D. C.

Jones, T.A., D.C. Nielson, D.G. Ogle, D.A. Johnson, and S.A. Young. 1998. Registration of Sand Hollow squirreltail germplasm. Crop Sci. 38:286.
Palmquist, D.E., R.A. Evans, and J.A. Young. 1987. Comparative analysis of temperature response surfaces. pp. 97-103 In: G.W. Frasier and R. A. Evans (eds.) Seed and Seedbed Ecology of Rangeland Plants. USDA, Agr. Res. Ser., Washington, D. C.

Wilson, F.D. 1963. Revision of Sitanion (Triticeae, Gramineae). Brittonia 15:303-323.

Young, J.A. and R.A. Evans. 1977. Squirreltail seed germination. J. Range Manage. 30:33-66.

Young, J.A. and R.A. Evans. 1978. Etiolated growth of range grasses for an indication of tolerance to atrazine. Weed Sci. 26:480-483.

Young, J.A. and R.A. Evans. 1982. Temperature profiles for germination of cool season grasses. ARR-W-72, USDA, ARS, Oakland, Calif. $92 \mathrm{p}$

Young, J.A., D.E. Palmquist, and R.A. Evans. 1991. Temperature profiles for germination of big sagebrush seeds from native stands. J. Range Manage, 44:385-390.

Young, J.A., R.A. Evans, R.E. Eckert, Jr., and B. L. Kay. 1987. Cheatgrass. Rangelands 9:266-270.

Young, J.A., B.L. Kay, H. George, and R.A. Evans. 1980. Germination of three species of Atriplex. Agron. J. 72:705-709. 


\title{
Contrasting responses of Intermountain West grasses to soil nitrogen
}

\author{
THOMAS A. MONACO*, DOUGLAS A. JOHNSON, JEANETTE M. NORTON, THOMAS A. JONES, KEVIN J. \\ CONNORS, JAY B. NORTON, AND MARGARET B. REDINBAUGH
}

Authors are Ecologist and Plant Physiologist, USDA-ARS Forage and Range Research Lab., Utah State Univ., Logan, Ut 84322-6300; Associate Professor, Plants, Soils, and Biometeorology Depart., Utah State Univ., Logan, Ut 84322-4820; Geneticist, Plant Physiologist, USDA-ARS Forage and Range Research Lab., Utah State Univ., Logan, Ut 84322-6300, Postdoctoral Research Associate, Plants, Soils, and Biometeorology Depart., Utah State Univ., Logan, Ut 84322-4820, and Molecular Geneticist, USDA-ARS Corn and Soybean Research, Wooster, Ohio 44691-4096.

\begin{abstract}
The mechanisms responsible for soil- $\mathrm{N}$-mediated species replacement of native perennial grasses by the invasive annual grasses cheatgrass (Bromus tectorum $\mathbf{L}$.) and medusahead (Taeniatherum caput-medusae [L.] Nevski) on rangelands are not completely understood. In addition, the contributions of distinct forms of inorganic $\mathrm{N}$ (i.e., $\mathrm{NH}_{4}{ }^{+}$and $\mathrm{NO}_{3}{ }^{-}$) to these shifts in species composition are currently unclear. Consequently, we conducted a greenhouse experiment to test 2 hypotheses: 1) that low $\mathbf{N}$ availability reduces growth (root and shoot) and $\mathbf{N}$ allocation of invasive annual seedlings more than native perennial species, and 2) that seedling growth and $\mathbf{N}$ allocation of invasive annual grasses is more responsive than native perennial grasses when supplied with $\mathrm{NO}_{3}^{-}$relative to $\mathrm{NH}_{4}^{+}$. We grew seedlings of 2 annual grasses and the native perennial grasses bluebunch wheatgrass (Pseudoroegneria spicata [Pursh] A. Löve), and 4 populations of squirreltail (Elymus elymoides [Raf.] Swezey; $E$. multisetus [J.G. Smith] M.E. Jones) in separate pots and exposed them to treatments differing in $\mathbf{N}$ form and availability for $\mathbf{1 7}$ weeks. Unexpectedly, root and shoot growth of annual grasses were equal or greater than native perennial grasses under low $\mathbf{N}$ availability. Annual grasses took up more $\mathrm{NO}_{3}{ }^{-}$and allocated more growth and $\mathbf{N}$ to shoots than the perennial grasses $(\mathrm{P}<$ $0.05)$. Perennial grasses had significantly greater root:shoot dry mass ratios than the invasive annual grasses across treatments ( $P$ $<0.05$ ). Invasive annual and native perennial grasses both had greater $(P<0.05)$ shoot and root mass and allocated more $\mathrm{N}$ to these structures when supplied with $\mathrm{NO}_{3}^{-}$relative to $\mathrm{NH}_{4}{ }^{+}$. The ecological implications of these growth and $\mathrm{N}$ allocation patterns in response to $\mathbf{N}$ availability and form provide important clues regarding the specific traits responsible for differences in competitive ability between invasive annual and native perennial grasses on semiarid rangelands.
\end{abstract}

Key Words: native perennial grass, invasive annual grass, nitrogen availability, nitrogen form, carbon-to-nitrogen ratio $(\mathrm{C}: \mathrm{N})$, seedling development, root development.

Research was funded by USDA-ARS and USDA-CSREES Grant No. 97 38300-4892. We thank E. Schupp, J. Young, and J. Krueger for insightful reviews of an earlier draft of the manuscript.

*Corresponding author and offprint requests: email:tmonaco@cc.usu.edu

Manuscript accepted 21 Jul. 02.

\section{Resumen}

Los mecanismos mediados por el nitrógeno del suelo responsables del reemplazo en pastizales de especies de zacates nativos perennes por los zacates invasores anuales "Cheatgrass" (Bromus tectorum L.) y 'Medusahead" no están completamente entendidos. Además, la contribución de las distintas formas de nitrógeno inorgánico $\left(\mathrm{NH}_{4}{ }^{+}\right.$y $\left.\mathrm{NO}_{3}{ }^{-}\right)$a estos cambios de composición de especies actualmente no esta clara. Consecuentemente, condujimos dos experimentos en invernadero para probar 2 hipótesis; 1) Una baja disponibilidad de $\mathbf{N}$ reduce el crecimiento (de raíz y tallos) y la distribución de $\mathrm{N}$ de las plántulas del zacate invasor anual más que en las especies perennes y 2) el crecimiento de las plántulas y la distribución de $\mathbf{N}$ de los zacates invasores anuales presentan una mayor respuesta que los zacates nativos perennes al suministro de $\mathrm{NO}_{3}{ }^{-}$en relación a $\mathrm{NH}_{4}{ }^{+}$. Durante 17 semanas desarrollamos plántulas de los dos zacates anuales y de los zacates nativos perennes "Bluebunch wheatgrass" (Pseudoroegneria spicata [Pursh] A. Löve) y de 4 poblaciones de "Squirreltail" (Elymus elymoides [Raf.] Swezey; E. multisetus [J.G. Smith] M.E. Jones), las plantas crecieron en macetas separadas y expuestas a diferentes formas y disponibilidad de $\mathbf{N}$. En una baja disponibilidad de $\mathbf{N}$ el crecimiento de raíz y tallos de los zacates anuales fue inesperadamente igual o mayor que el de los zacates nativos perennes. Los zacates anuales absorbieron más $\mathrm{NO}_{3}{ }^{-}$y asignaron mas crecimiento y $\mathrm{N}$ a los tallos que los zacatea nativos perennes $(P<\mathbf{0 . 0 5})$. Los zacates perennes tuvieron una relación de biomasa seca raíz:tallo mayor que los zacates invasores anuales, esto se presento en todos los tratamientos $(P<$ 0.05). Tanto los zacates anuales invasores como los nativos perennes tuvieron una mayor $(P<0.05)$ biomasas de tallos $y$ raíces y asignaron mas nitrógeno a estas estructuras cuando fueron suministrados con $\mathrm{NO}_{3}^{-}$en relación a $\mathrm{NH}_{4}{ }^{+}$. Las implicaciones ecológicas de estos patrones de crecimiento y distribución de $\mathbf{N}$ en respuesta a la forma $\mathbf{y}$ disponibilidad de $\mathbf{N}$ provee importantes indicios con respecto a las características específicas responsables de las diferencias en la capacidad competitiva entre los zacates anuales invasores y los nativos perennes de los pastizales semiáridos.

Cheatgrass (Bromus tectorum L.) and medusahead (Taeniatherum caput-medusae [L.] Nevski) are cool-season invasive annual grasses that reduce productivity, decrease biological diversity, and increase the frequency and intensity of wildfires on 
rangelands in the Intermountain West (Mack 1981, D'Antonio and Vitousek 1992, Young 1992). Repairing disturbed rangelands by re-establishing perennial grasses is extremely difficult because these annuals maintain dominance on disturbed sites by exhibiting high growth rates and seed production (Harris 1967, Wilson et al. 1974, Goebel et al. 1988, Aguirre and Johnson 1991). In addition, these invasive annual grasses are considered to be superior competitors for limited soil water (Harris and Wilson 1970, Melgoza et al. 1990) and nitrogen (N) (Dakheel et al. 1993, Link et al. 1995).

Soil $\mathrm{N}$ is a particularly important resource because its availability is inherently low under stable community conditions and may increase up to 12-fold following wildfire disturbance (Blank et al. 1994, 1996). Although many soil nutrients are important to plants, the availability of $\mathrm{N}$ most often limits productivity and intensifies competition among species in plant communities (McLendon and Redente 1991, 1992, Tilman and Wedin 1991). For example, field research suggests that addition of inorganic $\mathrm{N}$ to disturbed rangelands increases the relative abundance of cheatgrass (Wilson et al. 1966, Paschke et al. 2000), while reductions in $\mathrm{N}$ availability generally increases the relative abundance of perennials (Paschke et al. 2000). Reductions in soil $\mathrm{N}$ have also been shown to improve the competitive ability of bluebunch wheatgrass (Pseudoroegneria spicata [Pursh] A. Löve) relative to that of the invasive species spotted knapweed (Centaurea maculosa Lam.) in pot experiments (Herron et al. 2001). In addition, availability of the most abundant soil mineral $\mathrm{N}$ forms (i.e., $\mathrm{NO}_{3}^{-}$or $\mathrm{NH}_{4}{ }^{+}$) may influence the relative establishment of invasive annual or perennial grasses. For example, Young et al. $(1995,1998)$ found that fertilizing rangelands with $\mathrm{NO}_{3}{ }^{-}$ enhanced seedling emergence and establishment of medusahead, while fertilization with $\mathrm{NH}_{4}{ }^{+}$did not. Results from these field experiments suggest that manipulation of $\mathrm{N}$ form and availability may enhance the success of seeding perennial grasses into disturbed rangelands infested with cheatgrass and medusahead.

The mechanisms responsible for these $\mathrm{N}$-mediated shifts in species dominance, however, are not completely understood. Defining these mechanisms requires evaluation of the specific growth and/or functional traits that are altered by $\mathrm{N}$ availability. Do invasive annual grasses perform better than perennial grasses under high soil $\mathrm{N}$ availability because annuals have higher relative growth rates (Poorter et al. 1990, Lambers and Poorter 1992)? Although evidence exists that demonstrates that cheatgrass and medusahead have higher relative growth rates than native perennial grasses (Arredondo et al. 1998), it is unclear whether these annuals will be favored under conditions of high $\mathrm{N}$ availability, which has been observed for annuals in other plant communities (e.g., Aerts and Berendse 1988). Conversely, does low $\mathrm{N}$ availability reduce growth rates of invasive annual grasses so that relative performance of annual and perennial grasses are similar? Or do invasive annual and desirable perennial grasses differ in their nutrient-use efficiency (Chapin 1980) and biomass partitioning to shoots and roots when grown in low and high $\mathrm{N}$ supply (Hirose 1987)? Answers to these questions may provide important clues regarding the specific traits responsible for differences in competitive ability between invasive annual and desirable perennial grass species. In addition, this information may help in identifying management options to improve the success of seeding perennial grass species into rangelands dominated by cheatgrass or medusahead.

Here we report on the results of a greenhouse experiment that compared seedling growth of 2 invasive annual grasses and 5 native perennial grasses in response to treatments differing in $\mathrm{N}$ form and availability. Specifically, we compared plant biomass and $\mathrm{N}$ allocation to shoots and roots, tiller number per plant, and plantinduced changes in inorganic soil $\mathrm{N}$ of species grown separately in pots. We tested the following 2 hypotheses: 1) that low $\mathrm{N}$ availability reduces growth (root and shoot) and $\mathrm{N}$ allocation of invasive annual seedlings more than native perennial grasses, and 2) that seedling growth and $\mathrm{N}$ allocation of invasive annual grasses is more responsive than native perennial grasses when supplied with $\mathrm{NO}_{3}{ }^{-}$relative to $\mathrm{NH}_{4}{ }^{+}$.

\section{Materials and Methods}

\section{Soils}

The soil for our study was excavated from Dugway Proving Grounds (40 $14^{\circ}$ $23^{\prime \prime} \mathrm{N}, 112^{\circ} 50^{\prime} 47^{\prime \prime} \mathrm{W}$ ) in Tooele County, Ut. to a maximum depth of about $60 \mathrm{~cm}$. The top $2 \mathrm{~cm}$ of soil and litter was discarded to avoid existing seeds on the soil surface. The soil was a coarse loamy Xeric Torriorhents and a member of the Medburn Series (Trickler et al. 2000). Soil $\mathrm{pH}$ in distilled water was 8.2 , and cation exchange capacity (CEC) was $7 \mathrm{cmol} \mathrm{kg}^{-1}$ soil. Total soil carbon $(\mathrm{C})\left(13 \mathrm{~g} \mathrm{~kg}^{-1}\right)$ and total soil $\mathrm{N}\left(1 \mathrm{~g} \mathrm{~kg}^{-1}\right)$ were determined by direct combustion with a LECO CHN1000 autoanalyzer (LECO Corp., St. Joseph, Mich.) ${ }^{1}$. Soil gravimetric water contents at -0.033 and $-1.50 \mathrm{MPa}$ were 6.9 and $3.6 \%$, respectively. Soil was passed through a $6-\mathrm{mm}$ sieve to remove rocks and organic debris and thoroughly mixed. Soil equivalent to $7 \mathrm{~kg}$ oven-dry weight was added to individual plastic pots $(20 \mathrm{~cm}$ tall $\times 18 \mathrm{~cm}$ diameter at the base and $22 \mathrm{~cm}$ diameter at the top $\approx 8$ liter) with foam plugs inserted in the drainage holes to keep soil within the pot. This experiment was conducted in a greenhouse without artificial lighting from January to May 2000.

The following 5 soil treatments were established prior to planting grass seedlings: 1$)$ control $=$ no $\mathrm{N}$ added, 2) straw = barley $\operatorname{straw}\left(1 \mathrm{mg} \mathrm{kg}^{-1}\right.$ soil $)$ ground to pass a $1-\mathrm{mm}$ screen and thoroughly mixed with soil, 3) $\mathrm{NH}_{4}{ }^{+}=10 \mathrm{mg}$ $\mathrm{N} \mathrm{kg}^{-1}$ soil added as $\left.\left(\mathrm{NH}_{4}\right)_{2} \mathrm{SO}_{4}, 4\right) \mathrm{NH}_{4}{ }^{+}$ $+\mathrm{I}$ (nitrification inhibitor) $=10 \mathrm{mg} \mathrm{N} \mathrm{kg}^{-1}$ soil added as $\left(\mathrm{NH}_{4}\right)_{2} \mathrm{SO}_{4}+37 \mathrm{ml}$ nitrapyrin (29\% a.i., (2-chloro-6(trichloromethyl) pyridine), and 5) $\mathrm{NO}_{3}{ }^{-}=$ $10 \mathrm{mg} \mathrm{N} \mathrm{kg}{ }^{-1}$ soil added as $\mathrm{Ca}\left(\mathrm{NO}_{3}\right)_{2}$. Nitrapyrin inhibits the first nitrification step of bacterial $\mathrm{NH}_{4}{ }^{+}$oxidation and temporarily ( $\sim 60$ days) stabilizes $\mathrm{NH}_{4}{ }^{+}$in soils. The purpose of the straw treatment was to decrease overall inorganic $\mathrm{N}$ availability by promoting microbial immobilization of inorganic N. A preliminary evaluation indicated that nearly all extractable inorganic $\mathrm{N}$ was immobilized in the straw treatment within 5 days when soil moisture was brought to field capacity $(6.9 \%)$. All treatments were randomly applied to 28 pots with $600 \mathrm{ml}$ of water 2 days before planting. In addition, treatments 3,4 , and 5 were re-applied at half the initial rate of $\mathrm{N}$ (5 mg kg-1 soil) with $300 \mathrm{ml}$ of water 10 weeks after planting seedlings.

Soils were initially analyzed to quantify treatment effects on soil $\mathrm{NH}_{4}{ }^{+}$and $\mathrm{NO}_{3}{ }^{-}$ at 2 days after treatments were applied by taking soil cores ( 0 to $7 \mathrm{~cm}$ depth $x 1.5 \mathrm{~cm}$ diameter) from a subset of 3 pots of each treatment, which were not included in the experiment. Plant-or-microbe induced changes on soil $\mathrm{NH}_{4}{ }^{+}$and $\mathrm{NO}_{3}{ }^{-}$were measured from 1 soil core $(0$ to $20 \mathrm{~cm}$ depth $\times 1.5 \mathrm{~cm}$ ) from each pot at week 5

\footnotetext{
Mention ot a trade name does not imply an endorsement or recommendation by USDA over similar products or companies not mentioned.
} 
and from a subsample of the whole pot after roots were removed at the end of the experiment (week 17). Soil removed by coring was replaced with air-dried soil. All soil analyses were performed according to methods described by Hart et al. (1994). Soil samples were kept chilled until they were thoroughly mixed and extracted with $2 \mathrm{M} \mathrm{KCl}$ within 4 hours. The $\mathrm{KCl}$ solutions were filtered through pre-leached filter paper and frozen until analyzed. Concentrations of $\mathrm{NO}_{3}^{-}$and $\mathrm{NH}_{4}{ }^{+}$were analyzed colorimetrically with a flow injection autoanalyzer (Lachet Instruments, Milwaukee, Wis.)

\section{Plants}

The perennial grasses native to western North America that were used in our experiment included 'Goldar' bluebunch wheatgrass (Pseudoroegneria spicata [Pursh] A. Löve), 2 populations of big squirreltail: Sand Hollow and Seaman's Gulch (Elymus multisetus [J.G. Smith] M.E. Jones), and 2 populations of bottlebrush squirreltail: Little Camas (E. elymoides [Raf.] Sweezey ssp. brevifolius) and Little Wood (E. elymoides ssp. elymoides). The invasive annual grasses used in our experiment included cheatgrass and medusahead. Seeds of these invasive annuals were collected in Cache County, Ut $\left(41^{\circ} 46^{\prime} 07^{\prime \prime} \mathrm{N}, 111^{\circ} 47^{\prime} 11^{\prime \prime} \mathrm{W}\right.$ for cheatgrass and $41^{\circ} 32^{\prime} 18^{\prime \prime} \mathrm{N}, 111^{\circ} 48^{\prime \prime}$ $00^{\prime \prime} \mathrm{W}$ for medusahead). The short-lived squirreltails and long-lived bluebunch wheatgrass typically compete with the invasive annuals used in our experiment in many regions of the Intermountain West. The 7 taxa are hereafter referred to as grasses for simplicity of discussion. Each grass was randomly assigned to 4 pots per treatment. Seeds of each grass were germinated on blotter paper and transplanted 4 $\mathrm{cm}$ from the edge of each pot in a circular pattern to establish 5 plants per pot. After plant establishment, pots were watered 3 times each week with a syringe. Beginning at week 3, soil water content was adjusted weekly to the predetermined field capacity (6.9\% gravimetric soil water content). In addition, $70 \mathrm{~g}$ of perlite (processed siliceous rock) was added to the surface of each pot at week 4 to minimize evaporative loss from the pots.

Plant growth and tissue $\mathrm{N}$ variables were assessed on harvested plants at the end of the experiment (week 17). Number of tillers plant ${ }^{-1}$ was counted to obtain a mean for the 5 plants in each pot. Aboveground biomass of all plants was harvested at the soil surface, and root biomass (including crowns) was separated from the soil by sieving and then washing with water. Shoot and root components for each pot were dried at $55^{\circ} \mathrm{C}$ for 5 days to obtain dry mass values and then ground with a miniature coffee mill to pass through a $0.7-\mathrm{mm}$ mesh screen. Concentrations of total $\mathrm{C}$ and $\mathrm{N}$ for shoots and roots were determined by direct combustion with a LECO CHN-2000 autoanalyzer (LECO Corp., St. Joseph, Mich.). The concentration of $\mathrm{N}$ was multiplied by dry mass values to determine the amount of $\mathrm{N}$ in roots and shoots. In addition, $\mathrm{C}$ and $\mathrm{N}$ concentrations were used to calculate the carbon-to-nitrogen ratio $(\mathrm{C}: \mathrm{N})$ in roots and shoots. Initial soil concentrations of $\mathrm{NH}_{4}{ }^{+}$and $\mathrm{NO}_{3}^{-}$were analyzed with one-way analysis of variance (ANOVA) and means separated with the Tukey HSD test. Differences between soil treatments, grasses, and their interaction for the soil and plant variables were analyzed by twoway ANOVA. Treatment differences within each grass were tested with the Tukey HSD test after a one-way ANOVA, and statistical significance is shown in figures and tables. Differences between grasses within a treatment were tested with the Tukey HSD test after a one-way ANOVA, and statistical significance is discussed in the Results section. Differences are referred to as 'significant' when $\mathrm{P}<0.05$. Comparisons between the control and straw treatment were used to evaluate $\mathrm{N}$ availability effects (Hypothesis 1). Seedling responses to the $\mathrm{NH}_{4}{ }^{+}+\mathrm{I}$ and $\mathrm{NO}_{3}{ }^{-}$treatments were used to contrast the effects of $\mathrm{N}$ form (Hypothesis 2).

\section{Results}

Treatments designed to produce distinct $\mathrm{N}$-forms were established within a few days after application (Table 1). Initial soil $\mathrm{NH}_{4}^{+}$was significantly higher in the $\mathrm{NH}_{4}^{+}$and $\mathrm{NH}_{4}^{+}{ }^{+}+\mathrm{I}$ treatments than in

Table 1. Mean $( \pm 1 \mathrm{SE}, \mathrm{n}=3$ ) soil concentration of $\mathrm{NH}_{4}{ }^{+}$and $\mathrm{NO}_{3}^{-}$measured 2 days after initially applying treatments. Means within the same column followed by different letters are significantly different $(P<$ 0.05).

\begin{tabular}{lcc}
\hline \hline Treatment & $\mathrm{NH}_{4}{ }^{+}$ & $\mathrm{NO}_{3}^{-}$ \\
\hline & $----\mathrm{mg} \mathrm{N} \mathrm{kg}^{-1}$ & soil) \\
Control & $0.8 \pm 0.1 \mathrm{a}$ & $0.3 \pm 0.1 \mathrm{a}$ \\
Straw & $0.9 \pm 0.1 \mathrm{a}$ & $1.4 \pm 0.4 \mathrm{a}$ \\
$\mathrm{NH}_{4}{ }^{+}$ & $24.7 \pm 0.4 \mathrm{~b}$ & $1.1 \pm 1.0 \mathrm{a}$ \\
$\mathrm{NH}_{4}{ }^{+}+\mathrm{I}$ & $23.0 \pm 1.4 \mathrm{~b}$ & $0.8 \pm 0.3 \mathrm{a}$ \\
$\mathrm{NO}_{3}{ }^{-}$ & $0.8 \pm 0.1 \mathrm{a}$ & $17.8 \pm 0.4 \mathrm{~b}$ \\
\hline
\end{tabular}

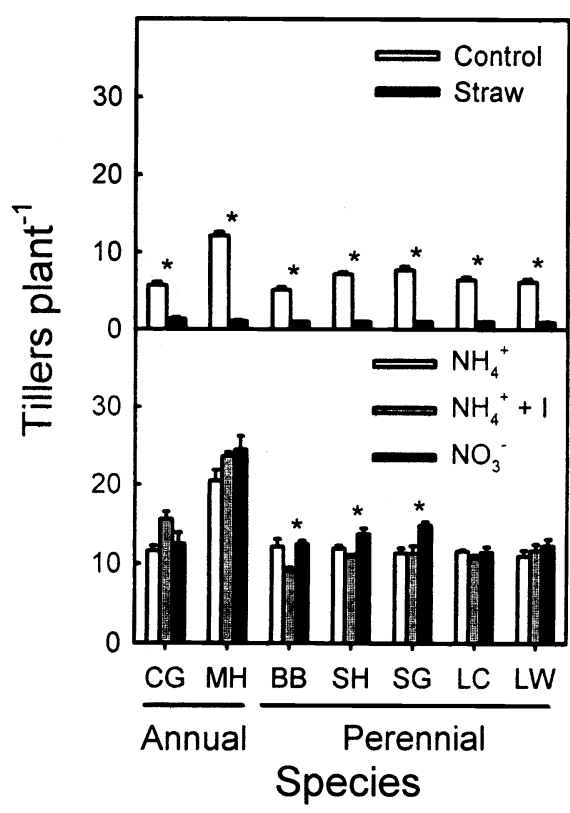

Fig. 1. Mean ( $\pm 1 \mathrm{SE})$ number of tillers plant $^{-1}$ for cheatgrass (CG), medusahead (MH), bluebunch wheatgrass (BB), and 4 squirreltails: Sandhollow (SH), Seaman's Gulch (SG), Little Camas (LC), and Little Wood $(L W)$. Plants were grown in 4 soil treatments for 17 weeks in a greenhouse to compare responses to $\mathrm{N}$ availability (control vs. straw) and $\mathrm{N}$ form $\left(\mathrm{NH}_{4}{ }^{+}+\mathrm{I}\right.$ vs. $\left.\mathrm{NO}_{3}{ }^{-}\right)$. Asterisks above bars denote significant $(P<0.05)$ differences between the respective 2-treatment comparisons.

the other treatments. By comparison, initial soil $\mathrm{NO}_{3}{ }^{-}$in the $\mathrm{NO}_{3}{ }^{-}$treatment was significantly greater ( $>20$ fold) than values of the other 4 treatments. Differences between the control and straw treatments for soil $\mathrm{NH}_{4}{ }^{+}$and $\mathrm{NO}_{3}{ }^{-}$were not initially detected. Plant growth and $\mathrm{N}$ allocation in the $\mathrm{NH}_{4}^{+}$treatment was usually intermediate to the $\mathrm{NH}_{4}{ }^{+}+\mathrm{I}$ and $\mathrm{NO}_{3}{ }^{-}$treatment.

Medusahead produced significantly more tillers per plant than any of the other species in all treatments except the straw treatment (Fig 1). Annual and perennial grass seedlings had similar numbers of tillers per plant within the straw treatment. A significant grass $x$ treatment interaction for number of tillers per plant indicated that grasses did not respond uniformly to $\mathrm{N}$ treatments (Table 2). Immobilizing soil $\mathrm{N}$ with the straw treatment significantly reduced the number of tillers per plant from values in the control by an average of $84 \%$ for the perennial grasses, $76 \%$ for cheatgrass, and $93 \%$ for medusahead. All species produced more tillers per plant in the $\mathrm{NO}_{3}{ }^{-}$treatment than in the $\mathrm{NH}_{4}^{+}+\mathrm{I}$ treatment except for cheatgrass. However, this $\mathrm{N}$ form effect was significant only for 
Table 2. Results of two-way analysis of variance (ANOVA) of growth variables for the $\mathbf{2}$ invasive annual and 5 native perennial grasses grown in 4 soil treatments for 17 weeks in a greenhouse. NS = not significant. Error term $\mathbf{~} \mathbf{=}=84$ (all tests).

\begin{tabular}{lccc}
\hline \hline Source of variation & $\begin{array}{c}\text { Treatment } \\
(\mathrm{df}=3)\end{array}$ & $\begin{array}{c}\text { Grasses } \\
(\mathrm{df}=6)\end{array}$ & $\begin{array}{c}\text { Treatment } x \text { Grasses } \\
(\mathrm{df}=18)\end{array}$ \\
\hline Tillers per plant & $\mathrm{P}<0.001$ & $\mathrm{P}<0.001$ & $\mathrm{P}<0.001$ \\
Shoot dry mass & $\mathrm{P}<0.001$ & $\mathrm{P}<0.001$ & $\mathrm{P}<0.001$ \\
Root dry mass & $\mathrm{P}<0.001$ & $\mathrm{P}<0.01$ & $\mathrm{NS}$ \\
Shoot $\mathrm{N}$ & $\mathrm{P}<0.001$ & $\mathrm{P}<0.001$ & $\mathrm{P}<0.001$ \\
Root $\mathrm{N}$ & $\mathrm{P}<0.001$ & $\mathrm{P}<0.001$ & $\mathrm{P}<0.001$ \\
Root:shoot ratio & $\mathrm{P}<0.001$ & $\mathrm{P}<0.001$ & $\mathrm{P}<0.01$ \\
Shoot $\mathrm{C}: \mathrm{N}$ ratio & $\mathrm{P}<0.001$ & $\mathrm{P}<0.001$ & $\mathrm{P}<0.001$ \\
Root C:N ratio & $\mathrm{P}<0.001$ & $\mathrm{NS}$ & $\mathrm{P}<0.001$ \\
5 week soil $\mathrm{NO}_{3}^{-}$ & $\mathrm{P}<0.001$ & $\mathrm{NS}$ & $\mathrm{NS}$ \\
5 week soil $\mathrm{NH}_{4}{ }^{+}$ & $\mathrm{P}<0.001$ & $\mathrm{NS}$ & $\mathrm{NS}$ \\
17 week soil $\mathrm{NO}_{3}{ }^{-}$ & $\mathrm{P}<0.001$ & $\mathrm{P}<0.05$ & $\mathrm{P}<0.01$ \\
17 week soil $\mathrm{NH}_{4}{ }^{+}$ & $\mathrm{NS}$ & $\mathrm{NS}$ & $\mathrm{NS}$ \\
\hline
\end{tabular}

bluebunch wheatgrass and Sandhollow and Seaman's Gulch big squirreltails.

Shoot dry mass of annual grass seedlings exceeded $(\mathrm{P}<0.05)$ that of the perennial grass seedlings for all treatments (Fig. 2). The straw treatment sustained significantly lower shoot dry mass than the control similarly for cheatgrass $(88 \%)$, medusahead $(91 \%)$, and the perennial species $(91 \%)$. Consequently, the significant species $\mathrm{x}$ treatment interaction for shoot dry mass (Table 2) was a result of greater shoot dry mass in the $\mathrm{NO}_{3}{ }^{-}$treatment compared to the $\mathrm{NH}_{4}{ }^{+}$treatment for both annual grasses and Sand Hollow big

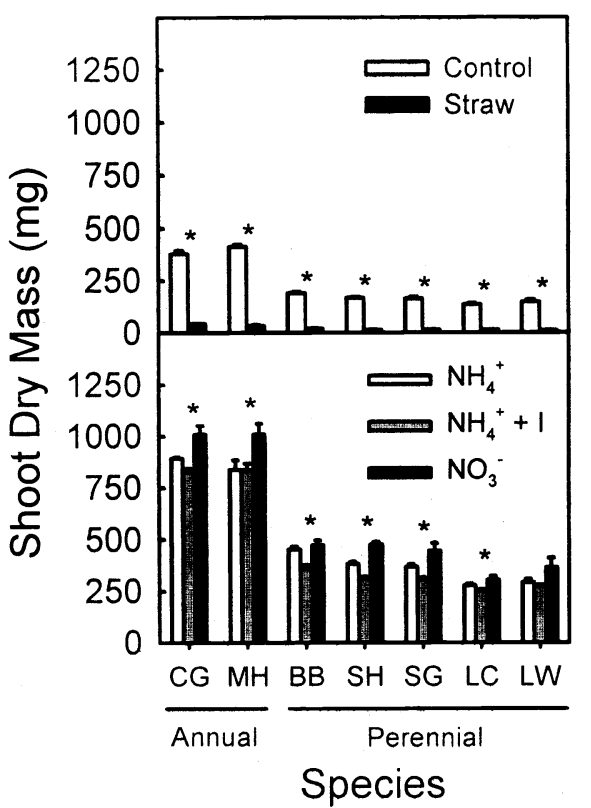
grasses. The absence of a significant grass $x$ treatment interaction for root dry mass indicated that annual and perennial seedlings responded equivalently to soil treatments (Table 2). Although not statistically significant, 4 of the 5 perennial Hollow big squirreltails, Little Camas botgrass) had greater root dry mass averaged across treatments than the invasive annual grasses. Low $\mathrm{N}$ availability in the straw treatment significantly reduced root dry mass by $92 \%$ from the control across all

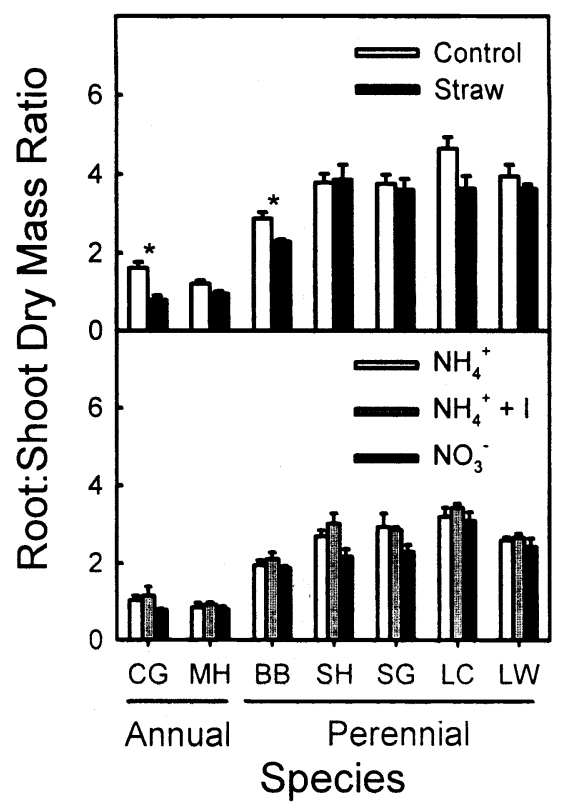
grasses (Seaman's Gulch and Sand tlebrush squirreltail, and bluebunch wheat-

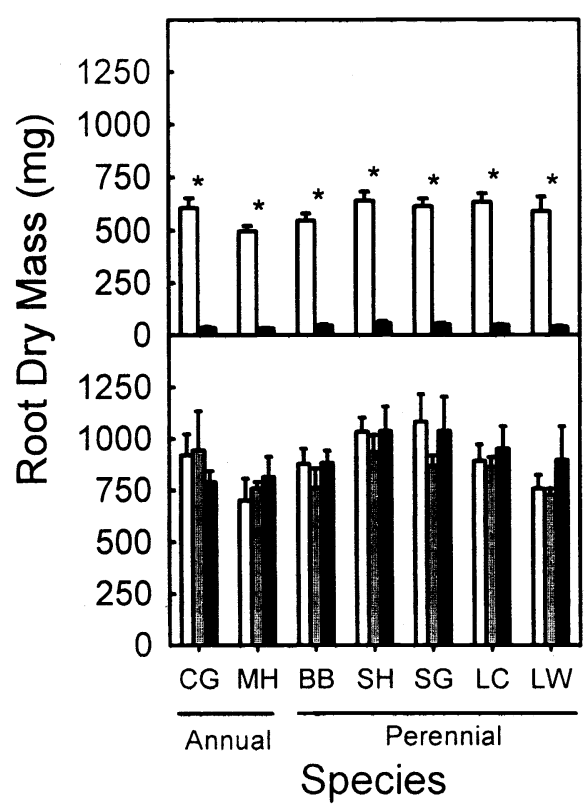

Fig. 2. Mean ( \pm 1 SE) shoot and root dry mass for cheatgrass (CG), medusahead (MH), bluebunch wheatgrass (BB), and 4 squirreltails: Sandhollow (SH), Seaman's Gulch (SG), Little Camas (LC), and Little Wood (LW). Plants were grown in 4 soil treatments for 17 weeks in a greenhouse to compare responses to $\mathrm{N}$ availability (control vs. straw) and $\mathbf{N}$ form $\left(\mathrm{NH}_{4}{ }^{+}\right.$ + I vs. $\left.\mathrm{NO}_{3}^{-}\right)$. Asterisks above bars denote significant $(\mathrm{P}<0.05)$ differences between the respective 2-treatment comparisons.
Fig. 3. Mean ( $\pm 1 \mathrm{SE})$ root:shoot dry mass ratio for cheatgrass (CG), medusahead (MH), bluebunch wheatgrass (BB), and 4 squirreltails: Sandhollow (SH), Seaman's Gulch (SG), Little Camas (LC), and Little Wood (LW). Plants were grown in 4 soil treatments for 17 weeks in a greenhouse to compare responses to $\mathbf{N}$ availability (control vs. straw) and $\mathrm{N}$ form $\left(\mathrm{NH}_{4}^{+}+\mathrm{I}\right.$ vs. $\left.\mathrm{NO}_{3}{ }^{-}\right)$. Asterisks above bars denote significant $(P<0.05)$ differences between the respective 2-treatment comparisons.

species (Fig. 2). In contrast, soil treatments that differed in $\mathrm{N}$ form did not significantly modify root dry mass.

Values for root:shoot dry mass ratio (RSR) of the invasive annual grasses were consistently lower $(P<0.05)$ than the native perennial grasses in each treatment (Fig. 3, Table 2). In addition, the 4 squirreltails consistently had greater RSR values than bluebunch wheatgrass. This significant grass $\mathrm{x}$ treatment interaction was a consequence of RSR values in the straw treatment being significantly lower than the control for cheatgrass and bluebunch wheatgrass, but none of the other 5 grasses. In contrast, no differences in RSR were observed between $\mathrm{N}$-form treatments for any grass.

Shoot $\mathrm{N}$ was generally greater in annual grasses, while root $\mathrm{N}$ was generally greater in perennial grasses (Fig. 4). For example, medusahead allocated more $\mathrm{N}$ to shoots than the perennials for all treatments $(P<0.05)$ except the straw treatment. Similarly, cheatgrass shoots contained more $\mathrm{N}$ than the squirreltails $(\mathrm{P}<$ 0.05 ), but not bluebunch wheatgrass, for all treatments. Medusahead roots had lower $\mathrm{N}$ content than all perennial grasses 

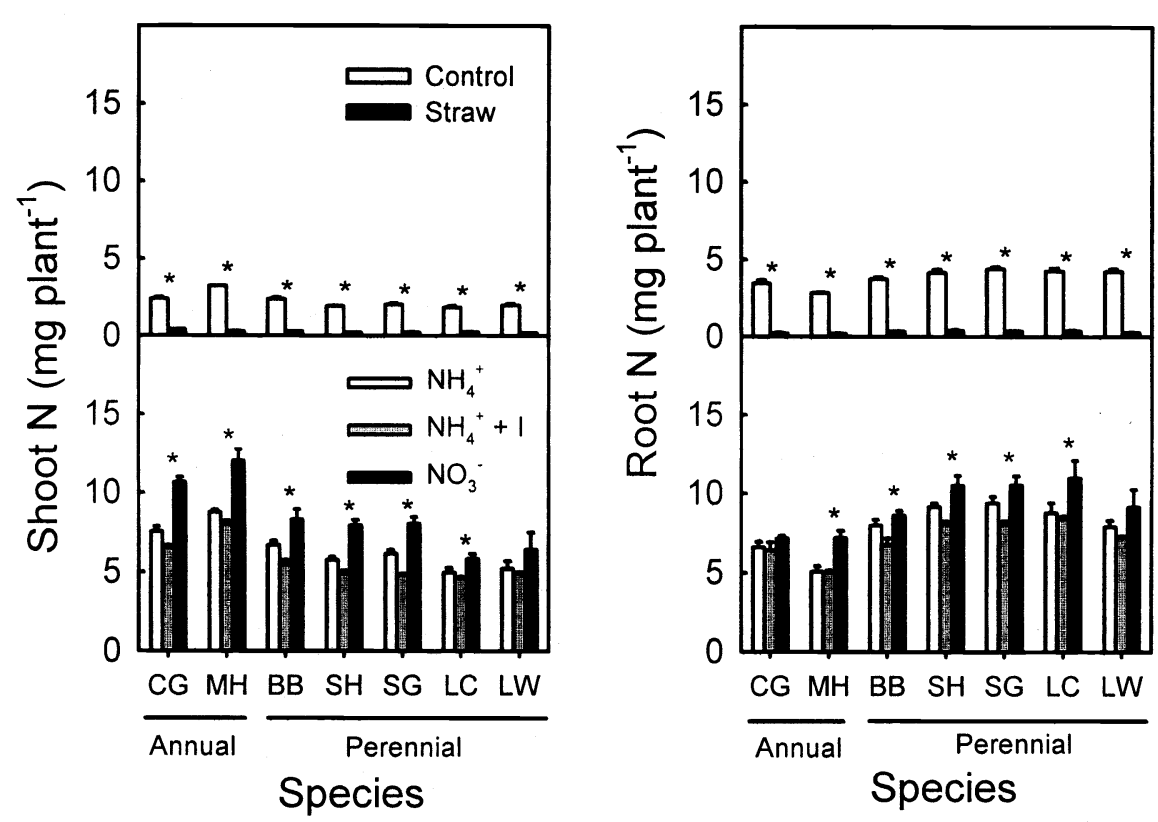

Fig. 4. Mean ( 1 SE) shoot and root $\mathbf{N}$ for (CG), medusahead (MH), bluebunch wheatgrass (BB), and 4 squirreltails: Sandhollow (SH), Seaman's Gulch (SG), Little Camas (LC), and Little Wood (LW). Plants were grown in 4 soil treatments for 17 weeks in a greenhouse to compare responses to $\mathrm{N}$ availability (control vs. straw) and $\mathrm{N}$ form $\left(\mathrm{NH}_{4}{ }^{+}+\mathrm{I}\right.$ vs. $\left.\mathrm{NO}_{3}{ }^{-}\right)$. Asterisks above bars denote significant $(\mathrm{P}<0.05)$ differences between the respective 2 treatment comparisons.

in the control and $\mathrm{NH}_{4}{ }^{+}$treatment $(\mathrm{P}<$ $0.05)$. In addition, root $\mathrm{N}$ of medusahead and cheatgrass was significantly less than Sandhollow and Seaman's Gulch big squirreltails, and Little Wood bottlebrush squirreltail in all treatments except the straw treatment. The straw treatment significantly reduced shoot and root $\mathrm{N}$ from the control by a similar percentage for all grasses. Shoots contained more $\mathrm{N}$ in the $\mathrm{NO}_{3}{ }^{-}$treatment than in the $\mathrm{NH}_{4}^{+}+\mathrm{I}$ treatment for all grasses except Little Wood bottlebrush squirreltail. Similarly, all grasses except Little Wood bottlebrush squirreltail and cheatgrass allocated significantly more $\mathrm{N}$ to roots in the $\mathrm{NO}_{3}{ }^{-}$ treatment than in the $\mathrm{NH}_{4}{ }^{+}+\mathrm{I}$ treatment. Consequently, we attribute the significant treatment $\mathrm{x}$ grass interactions for shoot and root $\mathrm{N}$ (Table 2) to species differences in response to the $\mathrm{NO}_{3}^{-}$and $\mathrm{NH}_{4}{ }^{+}+\mathrm{I}$ treatments, because these grasses demonstrated similar reductions from the control when inorganic soil $\mathrm{N}$ was immobilized by the straw treatment.

Invasive annual seedlings had greater $(\mathrm{P}$ $<0.05)$ shoot $\mathrm{C}: \mathrm{N}$ ratios than native perennial seedlings for all treatments (Fig. 5, Table 2). In the control treatment, shoot $\mathrm{C}: \mathrm{N}$ ratio of cheatgrass exceeded medusahead by $15 \%$ and the average for the perennial grasses by $47 \%$. Root $\mathrm{C}: \mathrm{N}$ ratios were generally greater for annual than root $\mathrm{C}: \mathrm{N}$ ratio was only significantly greater than both bottlebrush squirreltails. Average root $\mathrm{C}: \mathrm{N}$ pooled across species was significantly higher in the control treatment than in the straw $(6 \%), \mathrm{NH}_{4}{ }^{+}$ $(28 \%), \mathrm{NH}_{4}{ }^{+}+\mathrm{I}(26 \%)$, and $\mathrm{NO}_{3}{ }^{-}(37 \%)$ treatments. Low $\mathrm{N}$ availability produced by the straw treatment consistently reduced shoot $\mathrm{C}: \mathrm{N}$ ratios from the control for all grasses. By comparison, cheatgrass and medusahead were the only grasses to show a significant response to $\mathrm{N}$ form with lower shoot $\mathrm{C}: \mathrm{N}$ ratios in the $\mathrm{NO}_{3}{ }^{-}$ than $\mathrm{NH}_{4}{ }^{+}+$I treatment.

The 5 treatments produced significantly different soil $\mathrm{NH}_{4}{ }^{+}$and $\mathrm{NO}_{3}{ }^{-}$values measured at week 5; however, grasses had similar effects on soil $\mathrm{NH}_{4}{ }^{+}$and $\mathrm{NO}_{3}{ }^{-}$at this date (Fig. 6, Table 2). The amount of soil $\mathrm{NO}_{3}{ }^{-}$averaged across grasses remaining in the $\mathrm{NO}_{3}{ }^{-}$treatment at week 5 exceeded the straw treatment by $92 \%$, the control treatment by $68 \%$, the $\mathrm{NH}_{4}{ }^{+}$treatment by $32 \%$, and the $\mathrm{NH}_{4}{ }^{+}+\mathrm{I}$ treatment by $73 \%$. Soil $\mathrm{NH}_{4}{ }^{+}$values measured at week 5 were significantly greater in the $\mathrm{NH}_{4}{ }^{+}+$I treatment $\left(3.1 \mathrm{mg} \mathrm{kg}^{-1}\right)$ than values for the other treatments (range $=0.04$ to $0.18 \mathrm{mg} \mathrm{kg}^{-1}$ ) measured at week 5 . However, by week 17 , values for soil $\mathrm{NH}_{4}{ }^{+}$did not significantly differ between treatments or grasses (range $=0.13$ to 0.20 $\mathrm{mg} \mathrm{kg}^{-1}$ ) (Table 2). In contrast, at week 17, (0.05) than all grasses; however, cheatg 0.05 ) than all grasses; however, cheatgrass
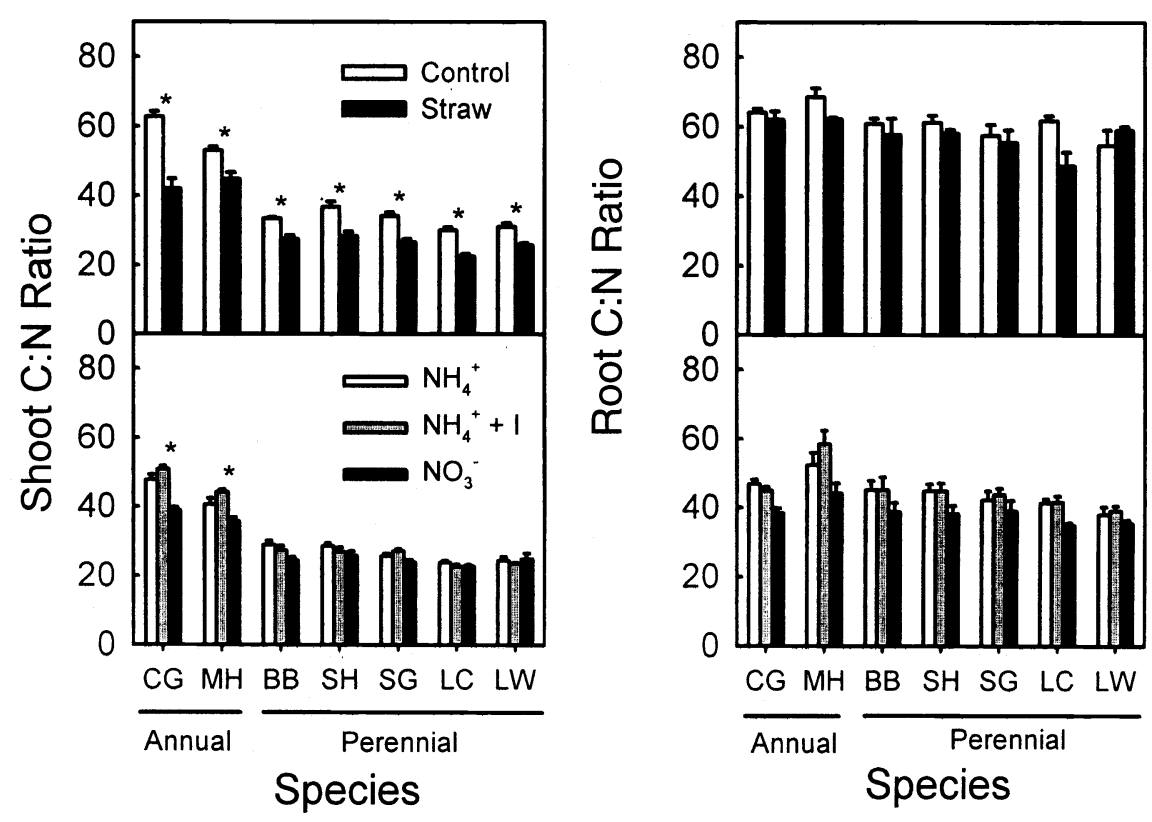

Fig. 5. Mean ( $\pm 1 \mathrm{SE})$ shoot and root carbon:nitrogen concentration ratio (C:N) for cheatgrass (CG), medusahead (MH), bluebunch wheatgrass (BB), and 4 squirreltails: Sandhollow (SH), Seaman's Gulch (SG), Little Camas (LC), and Little Wood (LW). Plants were grown in 4 soil treatments for 17 weeks in a greenhouse to compare responses to $\mathbf{N}$ availability (control vs. straw) and $\mathrm{N}$ form $\left(\mathrm{NH}_{4}{ }^{+}+\mathrm{I}\right.$ vs. $\left.\mathrm{NO}_{3}{ }^{-}\right)$. Asterisks above bars denote significant $(P<0.05)$ differences between the respective 2-treatment comparisons. 

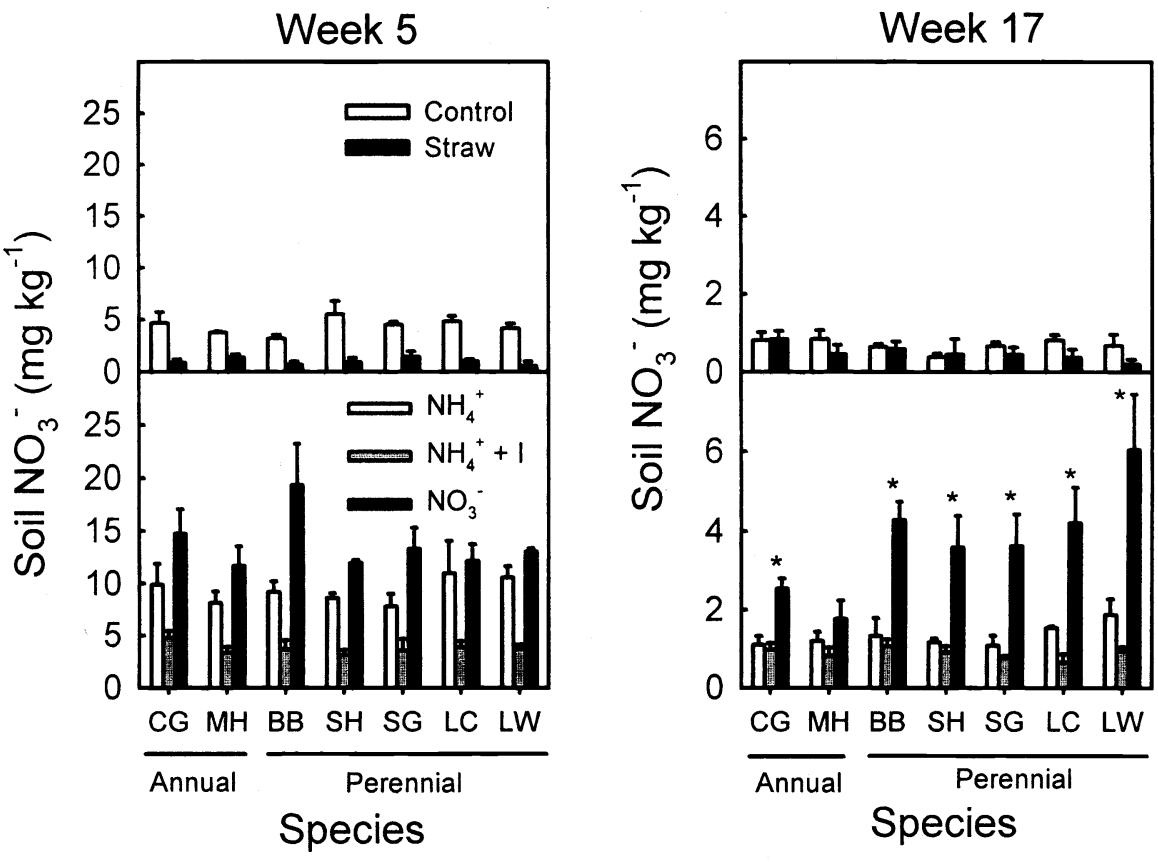

Fig. 6. Mean ( $\pm 1 \mathrm{SE}$ ) concentration of $\mathrm{NO}_{3}^{-}$measured in soils at 5 weeks and 17 weeks for cheatgrass (CG), medusahead (MH), bluebunch wheatgrass (BB), and 4 squirreltails: Sandhollow (SH), Seaman's Gulch (SG), Little Camas (LC), and Little Wood (LW). Plants were grown in 4 soil treatments for 17 weeks in a greenhouse to compare responses to $N$ availability (control vs. straw) and $\mathrm{N}$ form $\left(\mathrm{NH}_{4}^{+}+\mathrm{I}\right.$ vs. $\left.\mathrm{NO}_{3}{ }^{-}\right)$. Asterisks above bars denote significant $(\mathrm{P}<0.05)$ differences between the respective 2 -treatment comparisons.

treatment, grasses, and their interaction had significant effects on soil $\mathrm{NO}_{3}{ }^{-}$(Table 2). Significantly more $\mathrm{NO}_{3}{ }^{-}$remained in soils of the $\mathrm{NO}_{3}{ }^{-}$treatment than the other 4 treatments for all grasses except medusahead. Grasses had similar effects on soil $\mathrm{NO}_{3}{ }^{-}$for all treatments except the $\mathrm{NO}_{3}{ }^{-}$treatment, where cheatgrass and medusahead generally reduced soil $\mathrm{NO}_{3}{ }^{-}$ more than the perennial grasses. However, the only significant difference between species for soil $\mathrm{NO}_{3}{ }^{-}$in the $\mathrm{NO}_{3}{ }^{-}$treatment was between medusahead and Little Wood bottlebrush squirreltail.

\section{Discussion}

Low $\mathrm{N}$ availability induced by microbial immobilization drastically reduced plant growth and $\mathrm{N}$ allocation to roots and shoots of all species. Moreover, the magnitude of these reductions was similar for all species, even though invasive annuals produced more tillers per plant, had greater shoot dry mass, and allocated more $\mathrm{N}$ to shoots than perennials. On the basis of these results, we reject the hypothesis that low $\mathrm{N}$ availability reduces growth (root and shoot) and $\mathrm{N}$ allocation of invasive annual seedlings more than native perennial species, because low $\mathrm{N}$ availability affected both annual and perennial species similarly.

All grasses generally produced more tillers and allocated additional growth and $\mathrm{N}$ to shoots and roots when supplied $\mathrm{NO}_{3}{ }^{-}$ compared to $\mathrm{NH}_{4}{ }^{+}$. Thus, we did not observe a clear distinction between annual and perennial grasses when their relative responses to distinct forms of inorganic $\mathrm{N}$ were compared. Consequently, the hypothesis that seedling growth and $\mathrm{N}$ allocation of invasive annual grasses is more responsive than native perennial grasses when supplied with $\mathrm{NO}_{3}^{-}$relative to $\mathrm{NH}_{4}{ }^{+}$was also rejected.

\section{Low $\mathbf{N}$ availability}

The rejection of Hypothesis 1 necessitates an explanation for the greater or equal performance of invasive annual grasses compared with that of the native perennial grasses under low soil $\mathrm{N}$ availability. This hypothesis rejection also suggests that caution should be taken when assuming that low nutrient demand of perennial grasses translates into greater competitive ability under low $\mathrm{N}$ conditions. Others have observed similar results to ours in short-term pot experiments (Berendse et al. 1992, van der Werf et al. 1993a, 1993b), wherein fast and slowgrowing grass species responded similarly to low soil $\mathrm{N}$. These authors explained that fast-growing grasses initially allocate more carbon to root growth and take up more $\mathrm{N}$ per plant than slow-growing grasses, allowing them to produce more biomass than the slow-growing grasses under low $\mathrm{N}$ availability. However, $\mathrm{N}$ availability per plant (i.e., in pots) decreased through time for both species and led to decreased relative growth rates and increased allocation to roots (Hirose 1987), especially in the slow-growing species (van der Werf et al. 1993b). This response pattern closely resembles the responses observed in our experiment because the fast-growing invasive annual grasses (Arredondo et al. 1998) primarily allocated $\mathrm{N}$ and biomass to shoots, whereas allocation was primarily to roots in the slow-growing native perennial grasses. Thus, high growth rates in the invasive annuals may have enabled them to better exploit the limiting $\mathrm{N}$ supply in pots and perform relatively better or equal than the slow-growing native perennial grasses. Furthermore, our results indicate that the slower-growing native perennials allocated their acquired $\mathrm{N}$ and growth to roots at the expense of whole-plant growth, even though these slow-growing species are likely to be functioning closer to their 'optimal growth and metabolic rate' when soil $\mathrm{N}$ is limiting (e.g., Chapin et al. 1987).

Our results also demonstrated that the magnitude of differences in growth responses between annual and perennial grasses was lower when $\mathrm{N}$ was drastically reduced by microbial immobilization compared to the control or the $3 \mathrm{~N}$ addition treatments. Thus, under low soil $\mathrm{N}$, the relative performance of these 2 groups may be similar enough so that the slowgrowing native perennial grasses are capable of gradually replacing the fast-growing invasive annual grasses. For example, medusahead produced nearly twice as many tillers per plant than cheatgrass and the perennial grasses in the control treatment, but in the straw treatment, tiller numbers for medusahead were markedly reduced and comparable to the other species. Reducing the number of tillers per plant would also greatly limit the number of viable seeds to supplement invasive annual seedbanks. Limitations on seed production may be partly responsible for the reductions in cheatgrass (Redente et al. 1992, Paschke et al. 2000) and medusahead (Young et al. 1995, 1998) on semiarid rangelands when soil $\mathrm{N}$ is maintained low for multiple (3 to 5) years. 
Although invasive annual grasses showed equal or greater efficiency in acquiring soil $\mathrm{N}$ under limiting $\mathrm{N}$ conditions, the native perennial grasses displayed more efficient $\mathrm{N}$ use after $\mathrm{N}$ was acquired. Two main traits are generally recognized as contributing to competitive ability and efficient $\mathrm{N}$ use under nutrientpoor conditions: 1) relatively high investment of biomass in roots to enhance absorption (Chapin et al. 1987, Tilman 1988) and 2) low nutrient losses (leaf retention) and increased nutrient resorption from senescing leaves (Grime 1979, Berendse et al. 1992). We observed that the native perennial grasses in the present experiment displayed both of these traits to a greater extent than the invasive annual grasses. Perennial grasses primarily allocated $\mathrm{N}$ and biomass to roots and thus had significantly higher root:shoot ratios than the invasive annual grasses. Moreover, consistently lower leaf $\mathrm{C}: \mathrm{N}$ ratios, as observed in the native perennial grasses, reflected greater overall nutrient retention (per unit mass) and investment in perennial structures compared to the invasive annual grasses. Similarly, Redente et al. (1992) found that low soil $\mathrm{N}$ generated lower $\mathrm{C}: \mathrm{N}$ ratios and greater tissue $\mathrm{N}$ concentrations in late-seral, perennial species compared to early-seral, annual species in semiarid, shrub-steppe rangeland. These observations coupled with much greater leaf longevity in the perennial grasses help define the mechanism by which perennial grasses may increase their relative competitive ability through time when $\mathrm{N}$ availability remains limiting (e.g., Parrish and Bazzaz 1982, Schläpfer and Ryser 1996), even though the annual grasses have higher growth rates and $\mathrm{N}$ uptake efficiency in the short term. Thus, managing for continually low $\mathrm{N}$ availability appears to be a potential integrated weed management tool (e.g., Masters and Sheley 2001) to reduce the productivity of invasive annual grasses and provide a competitive advantage to slowgrowing native perennial grasses (Grime 1979, McGraw and Chapin 1989).

\section{High N Availability}

It has been known for many years that $\mathrm{N}$ fertilization on rangelands in the Intermountain West facilitates the replacement of native perennial grasses by invasive annual grasses such as cheatgrass (Wilson et al. 1966). Accordingly, current theories hypothesize that fluctuating resource availability is the key factor controlling the relative susceptibility of plant communities to invasive plant species (Huenneke et al. 1990, Milberg et al.
1999, Davis et al. 2000). Our results agree with previous reports that annual grasses are capable of maintaining higher growth rates than perennial grasses (Garnier 1992) through greater leaf $\mathrm{N}$ concentrations (Chapin 1980) and higher $\mathrm{N}$ absorption rate (Garnier and Vancaeyzeele 1994); however, invasive annual grasses have shorter growing periods (Jackson and Roy 1986). Higher growth rates enabled invasive annual species to take advantage of high $\mathrm{N}$ availability (e.g., Aerts and Berendse 1988) and produce significantly more shoot dry mass with higher $\mathrm{C}: \mathrm{N}$ ratios than the native species, regardless of treatment. In contrast, perennial grasses demonstrated less plasticity in shoot dry mass under high $\mathrm{N}$ availability. Greater responsiveness of invasive annual seedlings to high $\mathrm{N}$ availability, thus, increases their competitive ability and facilitates the replacement of desirable perennial grasses (e.g., Tilman 1982, McLendon and Redente 1992, Paschke et al. 2000), especially when inorganic soil $\mathrm{N}$ remains abundant (e.g., Bazzaz 1979 , Tilman 1987).

Our results suggest that efficient $\mathrm{N}$ uptake demonstrated by the invasive annual grasses compared to the native perennials resulted in greater depletion of soil $\mathrm{NO}_{3}{ }^{-}$within the $\mathrm{NO}_{3}{ }^{-}$treatment during the experiment. On the contrary, soil $\mathrm{NH}_{4}{ }^{+}$was depleted to similar levels by annual and perennial species during the experiment. These observations lead to the intriguing question: were the invasive annual grasses more responsive at both high and low soil availability because they were more efficient at extracting soil $\mathrm{NO}_{3}{ }^{-}$? If the answer is yes, it provides a plausible explanation for why increased availability of $\mathrm{NO}_{3}{ }^{-}$, but not $\mathrm{NH}_{4}{ }^{+}$, increased seedling establishment of medusahead from existing seedbanks (Young et al. 1995), while reducing nitrification (decreased availability of $\mathrm{NO}_{3}{ }^{-}$) effectively curtailed medusahead plant density (Young et al. 1998). It, therefore, seems likely that the availability of different forms of inorganic $\mathrm{N}\left(\mathrm{NO}_{3}{ }^{-}\right.$and $\mathrm{NH}_{4}{ }^{+}$) may be a way of effectively manipulating germination of invasive annual and desirable perennial species (e.g., Evans and Young 1975, Blank et al. 1994, Young et al. 1997). However, additional research is required to better define the positive or negative effects of distinct forms of inorganic $\mathrm{N}$ on germination for both invasive annual and native perennial grasses while controlling the inherent differences in seed dormancy that may exist within seedbanks.

\section{Management Implications}

Species dominance has been experimentally shifted by $\mathrm{N}$ availability in many plant community types including mesic heathland (Aerts and Berendse 1988), abandoned cropland (Tilman 1984, Wilson and Gerry 1995), shrub-steppe rangeland in North America (Redente et al. 1992, Gillen and Berg 1998, Paschke et al. 2000) and Australia (Hobbs and Atkins 1988, Snyman 2002), and arid shrublands (Milberg et al. 1999). However, few experiments have directly examined the Great Basin species evaluated in our experiment. With increased awareness of the impacts of atmospheric $\mathrm{N}$ deposition in many regions of the world (Morecroft et al. 1994, Vitousek et al. 1997, Kirkham 2001), it is imperative that the potential impacts of modifications in soil $\mathrm{N}$ on species composition and competitive interactions are better understood for rangelands. Based on the results of our study, we suggest that 3 specific research emphases may provide critical information to advance our understanding of soil $\mathrm{N}$ relations in rangeland plants. First, species preferences for $\mathrm{N}$ forms in a soil environment should be evaluated in experiments in which $\mathrm{N}$ forms are varied independently from $\mathrm{N}$ availability. Second, experiments that characterize the resource requirements or demands of invasive annual and desirable perennial grasses should be conducted to examine hypotheses regarding how the competitive balance of these 2 species groups may be controlled by $\mathrm{N}$ availability. Third, rangeland plant responses to $\mathrm{N}$ form and availability need to be scaled-up to the level of plant communities by evaluating the potential functional differences in $\mathrm{N}$ cycling between plant communities dominated by invasive annual grasses and those dominated by desirable perennial grasses (e.g., Bolton et al. 1990, Svejcar and Sheley 2001, Evans et al. 2001).

\section{Literature Cited}

Aerts, R. and F. Berendse. 1988. The effect of increased nutrient availability on vegetation dynamics in wet heathlands. Vegetatio 76:63-69.

Aguirre, L and D.A. Johnson. 1991. Influence of temperature and cheatgrass competition on seedling development of two bunchgrasses. J. Range Manage. 44:347-354.

Arredondo, J.T., T.A. Jones, and D.A. Johnson. 1998. Seedling growth of Intermountain perennial and weedy annual grasses. J. Range Manage. 51:584-589. 
Bazzaz, F.A. 1979. The physiological ecology of plant succession. Ann. Rev. Ecol. Syst. 10:351-371.

Berendse, F., W. Th. Elberse, and R.H.M.E. Geerts. 1992. Competition and nitrogen loss from plants in grassland ecosystems. Ecol. 73:46-53.

Blank, R.R., L. Agraham, and J.A. Young. 1994. Soil heating, nitrogen, cheatgrass, and seedbed microsites. J. Range Manage. 47:33-37.

Blank, R.R., F.L. Allen, and J.A. Young. 1996. Influence of simulated burning of soillitter from low sagebrush, squirreltail, cheatgrass, and medusahead on water-soluble anions and cations. Int. J. Wildland Fire 6:137-143.

Bolton, H., Jr., J.L. Smith, and R.E. Wildung. 1990. Nitrogen mineralization potentials of shrub-steppe soils with different disturbance histories. Soil. Sci. Soc. Amer. J. 54:887-891.

Chapin, F.S., III. 1980. The mineral nutrition of wild plants. Annu. Rev. Ecol. Syst. 11:233-260.

Chapin, F.S., III, A.J. Bloom, C.B. Field, and R.H. Waring. 1987. Plant responses to multiple environmental factors. Biosci. 37:49-57.

Dakheel, A.J., S.R. Radosevich, and M.G. Barbour. 1993. Effects of nitrogen and phosphorus on growth and interference between Bromus tectorum and Taeniatherum asperum. Weed Res. 33:415-422.

D'Antonio, C.M. and P.M. Vitousek. 1992. Biological invasions by exotic grasses, the grass/fire cycle, and global change. Annu. Rev. Ecol. Syst. 23:63-87.

Davis, M.A., P.G. Grime, and K. Thompson. 2000. Fluctuating resources in plant communities: a general theory of invasibility. J. Ecol. 88:528-534.

Evans, R.A. and J.A. Young. 1975. Enhancing germination of dormant seeds of downy brome. Weed Sci. 23:354-357.

Evans, R.D., R. Rimer, L. Sperry, and J. Belnap. 2001. Exotic plant invasion alters nitrogen dynamics in an arid grassland. Ecol. Appl. 11:1301-1310.

Garnier, E. 1992. Growth analysis of congeneric annual and perennial grass species. J. Ecol. 80:665-675.

Garnier E. and S. Vancaeyzeele. 1994. Carbon and nitrogen content of congeneric annual and perennial grass species: relationships with growth. Plant Cell Environ. 17:399-407.

Gillen, R.L., and W.A. Berg. 1998. Nitrogen fertilization of a native grass planting in western Oklahoma. J. Range Manage. 51:436-441.

Goebel, C.J., M. Tazi, and G.A. Harris. 1988. Secar bluebunch wheatgrass as a competitor to medusahead. J. Range Manage. 41:88-89.

Grime, J.P. 1979. Plant strategies and vegetation processes. John Wiley and Sons, N.Y.

Harris, G.A. 1967. Some competitive relationships between Agropyron spicatum and Bromus tectorum. Ecol. Monogr. 37:89-111.
Harris, G.A. and A.M. Wilson. 1970. Competition for moisture among seedlings of annual and perennial grasses as influenced by root elongation at low temperature. Ecol. 51:530-534.

Hart, S.C., J.M. Stark, E.A. Davidson, and M.K. Firestone. 1994. Nitrogen mineralization, immobilization and nitrification. $\mathrm{p}$. 985-1018. In: R.W. Weaver, S. Angle, P. Bottomley, D. Bezdicek, S. Smith, A Tabatabai, and A. Wollum (eds.) Methods of soil analysis microbiological and biochemical properties, Third edition. Soil Sci. Soc. of Amer., Madison, Wis.

Herron, G.J., R.L. Sheley, B.D. Maxwell, and J.S. Jacobsen. 2001. Influence of nutrient availability on the interaction between spotted knapweed and bluebunch wheatgrass. Rest. Ecol. 9:326-331.

Hirose, T. 1987. A vegetative growth model: adaptive significance of phenotypic plasticity in matter partitioning. Funct. Ecol. 1:195-202.

Hobbs, R.J. and L. Atkins. 1988. Effect of disturbance and nutrient addition on native and introduced annuals in plant communities in the Western Australian wheatbelt. Aust. J. Ecol. 13:171-179.

Huenneke, L.F., S.P. Hamburg, R. Koide, H.A. Mooney, and P.M. Vitousek. 1990. Effects of soil resources on plant invasion and community structure in Californian serpentine grassland. Ecol. 71:478-491.

Jackson, L.E. and J. Roy. 1986. Growth patterns of Mediterranean annual and perennial grasses under simulated rainfall regimes of southern France and California. Acta Oecol. Ecol. Plant. 7:191-212.

Kirkham, F.W. 2001. Nitrogen uptake and nutrient limitation in six hill moorland species in relation to atmospheric nitrogen deposition in England and Wales. J. Ecol. 89:1041-1053.

Lambers, H. and H. Poorter. 1992. Inherent variation in growth rate between higher plants: a search for physiological causes and ecological consequences. Adv. Ecol. Res. 23:188-261

Link, S.O., H. Bolton, Jr., M.E. Thiede, and W.H. Rickard. 1995. Responses of downy brome to nitrogen and water. J. Range Manage. 48:290-297.

Mack, R.N. 1981. Invasions of Bromus tectorum L. into western North American: an ecological chronicle. Agro-ecosystems 7:145-165.

Masters, R.A. and R.L. Sheley. 2001. Principles and practices for managing rangeland invasive plants. J. Range Manage. 54:502-517.

McGraw, J.B. and F.S. Chapin, III. 1989. Competitive ability and adaptation to fertile and infertile soils in two Eriophorum species. Ecol. 70:736-749.

McLendon, T. and E.F. Redente. 1991 Nitrogen and phosphorus effects on secondary succession dynamics on a semi-arid sagebrush site. Ecol. 72:2016-2024.

McLendon, T. and E.F. Redente. 1992. Effects of nitrogen limitation on species replacement dynamics during early succession on a semiarid sagebrush site. Oecologia 91:312-317.

Melgoza, G., R.S. Nowak, and R.J. Tausch. 1990. Soil water exploitation after fire: competition between Bromus tectorum (cheatgrass) and two native species. Oecologia 83:7-13.

Milberg, P., B.B. Lamont, and M.A. PérezFernández. 1999. Survival and growth of native and exotic composites in response to a nutrient gradient. Plant Ecol. 145:125-132.

Morecroft, M.D., E.K. Sellers, and J.A. Lee. 1994. An experimental investigation into the effects of atmospheric nitrogen deposition on two semi-natural grasslands. J. Ecol. 82:475-483

Parrish, J.A.D. and F.A. Bazzaz. 1982. Competitive interactions in plant communities of different successional ages. Ecol. 63:314-320

Paschke, M.W., T. McLendon, and E.F. Redente. 2000. Nitrogen availability and old-field succession in a shortgrass steppe. Ecosystems 3:144-158.

Poorter, H., C. Remkes, and H. Lambers. 1990. Carbon and nitrogen ecology of 24 wild species differing in relative growth rate. Plant Physiol. 94:621-627.

Redente, E.F., J.E. Friedlander, and T. McLendon. 1992. Response of early and late semiarid seral species to nitrogen and phosphorus gradients. Plant Soil 140:127-135.

Schläpfer, B. and P. Ryser. 1996. Leaf and root turnover of three ecologically contrasting grass species in relation to their performance along a productivity gradient. Oikos 75:398-406

Snyman, H.A. 2002. Short-term response of rangeland botanical composition and productivity to fertilization ( $\mathrm{N}$ and $\mathrm{P}$ ) in a semi-arid climate of South Africa. J. Arid. Environ. 50:167-183.

Svejcar, T. and R. Sheley. 2001. Nitrogen dynamics in perennial- and annual-dominated arid rangeland. J. Arid. Environ. 47:33-46.

Tilman, D. 1982. Resource competition and community structure. Monographs in population biology 17. Princeton Univ. Press, Princeton, N.J.

Tilman, D. 1984. Plant dominance along an experimental nutrient gradient. Ecol. 65:1445-1453.

Tilman, D. 1987. Secondary succession and the pattern of plant dominance along experimental nitrogen gradients. Ecol. Monogr. 57:189-214.

Tilman, D. 1988. Plant strategies and the structure and dynamics of plant communities. Princeton Univ. Press, Princeton, N.J.

Tilman, D. and D.A. Wedin. 1991. Dynamics of nitrogen competition between successional grasses. Ecol. 72:685-700.

Trickler, D.L., D.T. Hall, C.D. Franks, S.K. Ferguson, L.B. Campbell, P.J. Savage, and J.E. Brewer. 2000. Soil survey of Tooele area, Utah. United States Government Printing Office, Washington D.C. 
van der Werf, A., M. van Nuenen, A.J. Visser, and H. Lambers. 1993a. Contribution of physiological and morphological plant traits to a species' competitive ability at high and low nitrogen supply. Oecologia 94:434-440.

van der Werf, A., A.J. Visser, F. Schieving, and H. Lambers. 1993b. Evidence for optimal partitioning of biomass and nitrogen at a range of nitrogen availabilities for fast and slow-growing species. Funct. Ecol. 7:63-74.

Vitousek, P.M., J.D. Aber, R.W. Howarth, G.E. Likens, P.A. Matson, D.W. Schindler, W.H. Schlesinger, and D. Tilman. 1997. Human alteration of the global nitrogen cycle: sources and consequences. Ecol. Appl. 7:737-750.
Wilson, A.M., G.A. Harris, and D.H. Gates. 1966. Fertilization of mixed cheatgrass-bluebunch wheatgrass stands. J. Range Manage. 19:134-137.

Wilson, A.M., D.E. Wondercheck, and C.J. Goebel. 1974. Responses of range grass seeds to winter environments. J. Range Manage. 32:209-213.

Wilson, S.D. and A.K. Gerry. 1995. Strategies for mixed-grass prairie restoration: herbicide, tilling, and nitrogen manipulation. Rest. Ecol. 3:290--298.

Young, J.A. 1992. Ecology and management of medusahead (Taeniatherum caput medusae ssp. asperum [Simk.] Melderis). Great Basin Natur. 52:245-252.
Young, J.A., R.R. Blank, and W.S Longland. 1995. Nitrogen enrichmentimmobilization to control succession in arid land plant communities. J. Arid Land Stud. 5S:57-60.

Young, J.A., C.D. Clements, and R.R. Blank. 1997. Influence of nitrogen on antelope bitterbrush seedling establishment. J. Range Manage. 50:536-540.

Young, J.A., J.D. Trent, R.R. Blank, and D.E. Palmquist. 1998. Nitrogen interactions with medusahead (Taeniatherum caputmedusae ssp. asperum) seedbanks. Weed Sci. 46:191-195. 


\title{
Biological and chemical response of a grassland soil to burning
}

\author{
LILIANA I. PICONE, GABRIELA QUAGLIA, FERNANDO O. GARCIA, AND PEDRO LATERRA
}

Authors are Assistant Professor; Graduate Student, Facultad de Ciencias Agrarias (UNMdP)-Estación Experimental Agropecuaria Balcarce (INTA), C.C. 276, (7620) Balcarce, Argentina; director Latin American-Southern Cone, INPOFOS. CONO SUR. (1641) Acassuso, Buenos Aires, Argentina.; and Associate Professor, Facultad de Ciencias Agrarias (UNMdP)-Estación Experimental Agropecuaria Balcarce (INTA), C.C. 276, (7620) Balcarce, Argentina. *Corresponding author (E-mail):lpicone@balcarce.inta.gov.ar

\begin{abstract}
Changes in soil nutrient pools and microbial activity due to fire are important for understanding the availability of nutrients to plants. The objective of this study was to evaluate the effect of fire: 1) on size and seasonal dynamics of labile pools of $\mathbf{C}$ and $\mathrm{N}$ in a short-term after burning; and II) on chemical properties and microbial diversity immediately after fire, in a grassland with Paspalum quadrifarium Lam. Microbial biomass $\mathrm{C}$ and $\mathrm{N}$ tended to be higher in the burned (433 mg C kg-1 and $37 \mathrm{mg} \mathrm{N} \mathrm{kg}^{-1}$ ) than in the unburned treatment (386 mg C kg-1 and $\left.26 \mathrm{mg} \mathrm{N} \mathrm{kg}^{-1}\right)$. Both microbial biomass, decreased at the beginning of the growing season and then recovered at the end of the season. Levels of mineralizable $\mathbf{C}$ and $\mathbf{N}$ were similar in both treatments; however they showed different patterns of seasonal transformations. At initiation of plant growth, concentration of mineralizable $\mathbf{C}$ decreased while amount of mineralizable $N$ increased; but the opposite occurred at the end of the growing season. Increases in microbial biomass coincided with low levels of mineralizable $\mathbf{N}$ and high concentrations of mineralizable $\mathrm{C}$, suggesting a higher immobilization at the end of the season. Immediately after burning, organic $\mathrm{C}$ and $\mathrm{N}$ decreased by 11 and $7 \%$, respectively. Mineral $N$ was almost double, available $P$ increased by $10 \mathrm{mg} \mathrm{kg}^{-1}$; but exchangeable bases, bacterial and actinomycetes population, and urease activity were not affected by burning. Fire can induce immediate changes to the soil; however, long-term studies will be required to evaluate the duration of the effect of fire on soil biological processes and nutrient transformations.
\end{abstract}

Key Words: Paspalum quadrifarium, fire, microbial biomass, soil nutrients, flooding pampa

Flooding Pampa is a region characterized by poorly drained soils that occupies approximately $58,000 \mathrm{~km}^{2}$ in the central-eastern area of Buenos Aires province $\left(35^{\circ} 30^{\prime} \mathrm{N}, 37^{\circ} 40^{\prime} \mathrm{S}, 56^{\circ} 50^{\prime} \mathrm{E}\right.$, $60^{\circ} 30^{\prime} \mathrm{W}$ ) in Argentina. Most of this area is under natural grasslands, which have undergone significant changes in physiognomy and species composition. However, extended stands of pristine plant communities dominated by Paspalum quadrifarium Lam. still exist.

Paspalum quadrifarium Lam. is a warm-season and perennial grass with tall canopy that excludes other species, and forms

Research was funded by Facultad de Ciencias Agrarias-Universidad Nacional de Mar del Plata (UNMdP) Grant AGR 20-93.

Manuscript accepted 16 Jul. 02
Resumen

Estudiar los cambios en los nutrientes del suelo y la actividad microbiana producidos por el fuego es importante para poder entender la disponibilidad de nutrientes para las plantas. EI objetivo de este estudio fue evaluar el efecto del fuego I) sobre el tamaño y la dinámica de los pooles lábiles de $\mathrm{C}$ y $\mathbf{N}$, a corto plazo después de la quema; y II) sobre las propiedades químicas y la diversidad biológica, inmediatamente luego de efectuada la quema, en una pastura natural con predominio de Paspalum quadrifarium Lam. El C y $\mathbf{N}$ de la biomasa microbiana tendieron a ser mayores en el tratamiento de quema $\left(433 \mathrm{mg} \mathrm{C} \mathrm{kg}^{-1}\right.$ y 37 mg $\mathrm{N} \mathrm{kg}^{-1}$ ) que en el tratamiento de no quema $\left(386 \mathrm{mg} \mathrm{C}^{-1} \mathrm{~g}^{-1}\right.$

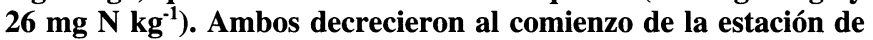
crecimiento de la pastura y se recuperaron al final de la misma. Los niveles de $\mathbf{C}$ y $\mathbf{N}$ mineralizable fueron similares en ambos tratamientos; sin embargo ellos mostraron patrones diferentes de variación estacional. Al inicio del crecimiento vegetal, la concentración de $\mathbf{C}$ mineralizable decreció mientras que el contenido de $\mathbf{N}$ mineralizable incrementó; lo opuesto ocurrió al final de la estación de crecimiento. Los incrementos en biomasa microbiana coincidieron con los bajos niveles de $\mathbf{N}$ mineralizable y la alta concentración de $\mathbf{C}$ mineralizable sugiriendo una mayor inmovilización al comienzo de la estación de crecimiento. Inmediatamente luego del fuego, el $\mathbf{C}$ y $\mathbf{N}$ orgánico decreció en un 11 y 7\%, respectivamente. La concentración de $\mathbf{N}$ mineral fue casi el doble, el $P$ disponible incrementó en $10 \mathrm{mg} \mathrm{kg}-1$; sin embargo las bases intercambiables, y la población de bacteria y actinomicetes como la actividad ureasa no fueron afectadas por el fuego. La quema puede inducir cambios inmediatos en el suelo, no obstante estudios a largo plazo son necesarios para evaluar la duración del efecto del fuego sobre los procesos biológicos y las transformaciones de nutrientes.

dense stands locally known as 'pajonales'. A small amount of the dead foliage falls on the soil surface, and it decomposes at slow rates because of its low nutritive value. About $70-80 \%$ of the aboveground dead plant material remains as standing dead biomass, exceeding $20 \mathrm{Mg}$ dry matter ha ${ }^{-1}$ (Cahuépé and Laterra 1998). Winter-spring burning is a common management practice, which increases the productivity of these grasslands (Sakalauskas et al. 2001), cattle stocking rates (Cahuépé 1990) and nutritive quality of forage (Sacido et al. 1995).

Fire changes soil properties as a result of direct exposure to high temperatures and ash deposition. Furthermore, there are indirect and after-fire longer term effects caused by changes in 
microclimate and plant species composition (Raison et al. 1990). These changes depend on, among other factors, duration of fire, maximum burn temperature, soil texture, and water content (Wright and Bailey 1982). Several studies on the effect of fire on soils have shown changes in soil nutrient levels resulting mainly in total $\mathrm{N}$ losses, but short-term increases in available $\mathrm{N}$ and other nutrients (Biederbeck et al. 1980, Kutiel and Naveh 1987, Fenn et al. 1993, Saá et al. 1998). Soil chemical properties such as exchangeable $\mathrm{Ca}^{++}$, $\mathrm{Mg}^{++}$and $\mathrm{K}^{+}$, and $\mathrm{pH}$ also increase after fire (Tomkins et al. 1991). Microbial biomass is considered an agent of transformation of soil organic materials, and a labile reservoir of nutrients such as $\mathrm{N}, \mathrm{P}$, and $\mathrm{S}$ (Jenkinson and Ladd 1981). Ojima (1987) found that microbial biomass $\mathrm{C}$ and $\mathrm{N}$ were reduced by long-term annual burning ( $>40 \mathrm{yr}$ ), but they were not affected by short-term burning (1-2 yr).

Most research on the effects of fire on grasslands has focused on shifts in plant species composition and plant community productivity (Ricci et al. 1996, Laterra 1997, Laterra et al. 1998) providing scarce information about the impact of fire on soil properties, nutrient availability, and microbial activity. The objective of this study was to evaluate the effect of fire 1) on the size and seasonal dynamics of soil microbial biomass $\mathrm{C}$ and $\mathrm{N}$ in a short-term after burning; and II) on some soil chemical properties and microbial diversity, immediately after a single fire. This study along with others which are being carried out would contribute to obtain a better understanding of soil nutrient transformations and microbial activity in a burned system.

\section{Materials and Methods}

\section{Experimental site}

The study was conducted on several plots in a natural grassland located at San Ignacio $\left(37^{\circ} 10^{\prime} 37^{\prime \prime} \mathrm{S}, 58^{\circ} 25^{\prime} 50^{\prime \prime} \mathrm{W}\right)$, about $20 \mathrm{~km}$ south of Ayacucho district, in the southeast of Buenos Aires province (Argentina). The soil belongs to subgroup Typic Natraquoll, which is generally water-logged during late winter and early spring. The local climate is characterized by a mean annual temperature and median annual precipitation of $15^{\circ} \mathrm{C}$ and 1,029 $\mathrm{mm}$ respectively, with summer droughts and spring floods. The area is a natural grassland composed of 2 types of vegetation, which can be clearly distinguished by their composition and structure. The vegetation that covers most of the area and extends over lower topographical positions is composed of short grasses such as Leersia hexandra Sw., Hordeum pusillum Nutt., and Distichlis spicata (L.) Green. Paspalum quadrifarium Lam. represents patches within the landscape, which are located on slight slopes. The experimental site was selected to take into account the equal physiognomy of patches and the predominance of Paspalum quadrifarium Lam. in the grassland.

\section{Experiment I}

Experiment I was carried out in an area, which had been burned in August 1990. In December 1990, when there was approximately $30 \mathrm{~cm}$ of post-fire regrowth, the eastern area (block I) was grazed for 5 months until May 1991, while the western area (block II) was left ungrazed. From May 1991 to August 1992 both blocks remained ungrazed, and at this time we delimited 4 plots within each block. Treatments, burned and unburned, were randomly assigned to experimental units within a block, with each treatment appearing twice in every block.

Plots were burned on 26 August 1992, in winter. Burning was done up wind to allow a slow and complete fuel combustion, and also a better control of fire. Prior to burning, canopy of Paspalum quadrifarium Lam. had a mean height of $95 \mathrm{~cm}$, and the aerial biomass was 1,555 and $1,808 \mathrm{~g} \mathrm{~m}^{-2}$ in block I and II, respectively. During burning, the mean wind speed was $1.8 \mathrm{~m} \mathrm{sec}^{-1}$ and the maximum temperature at the ground level exceeded $390^{\circ} \mathrm{C}$. Maximum fire temperature was estimated using 8 sets of glass capillary tubes filled with substances, which melted at a different temperature $\left(39-350^{\circ} \mathrm{C}\right)$.

Soil samples were taken from the upper $12 \mathrm{~cm}$ layer of each treatment at different dates: 1, 58, 215, and 360 days after burning. Each soil sample was a composite of 25-30 cores ( $2.5 \mathrm{~cm}$ diam.) collected randomly from each experimental unit, among plants.

\section{Experiment II}

Three homogeneous plots were selected from a site located close to experiment I. These plots were not previously burned. Two treatments, burned and unburned, were set-up in a randomized complete block design with 3 replications. Burning was done on 18 November 1994, in spring. Prior burning, aerial biomass was $1,847 \mathrm{~g} \mathrm{~m}^{-2}$, with $86 \%$ of dead standing biomass. During burning, the mean wind speed was $5 \mathrm{~m} \mathrm{sec}^{-1}$ and the maximum burn temperature at ground level ranged from 152 to $677^{\circ} \mathrm{C}$. Temperature was measured using heat sensitive crayons (Tempilsticks (R), Big Three Industries, Inc. Hamilton Blvd., South Plainfield, N.J. 07080, USA) placed at soil level, among plants.

Soil samples were taken from the 0 - to 5 $\mathrm{cm}$ depth, 1 day after burning in both treatments. Each soil sample was a composite of $25-30$ cores $(2.5 \mathrm{~cm}$ diam.) collected at random from the experimental unit, without removing either the existing litter prior to burning or the ashes after burning.

\section{Biological and chemical analyses}

For chemical analyses (organic C, organic and inorganic $\mathrm{N}, \mathrm{pH}$, available $\mathrm{P}$, cation exchange capacity (CEC), and exchangeable $\mathrm{Ca}^{++}, \mathrm{Mg}^{++}, \mathrm{K}^{+}$, and $\mathrm{Na}^{+}$) soil samples were air-dried and sieved through 2 or $0.5 \mathrm{~mm}$ screens depending on the analytical technique. For microbial and biochemical analyses (microbial biomass $\mathrm{C}$ and $\mathrm{N}$, number of bacteria and actinomycetes, and urease activity) moist soil samples were passed through a $4 \mathrm{~mm}$ mesh to remove plant material.

Soil organic $\mathrm{C}$ content was analyzed with the technique of Walkley and Black (1934), soil organic $\mathrm{N}$ by Kjeldahl digestion (Bremner and Mulvaney 1982), and available $\mathrm{P}$ according to method of Bray and Kurtz (1945). Inorganic $\mathrm{N}\left(\mathrm{NH}_{4}^{+}-\mathrm{N}\right.$ and $\mathrm{NO}_{3}{ }^{-}-\mathrm{N}$ ) was determined on $0.5 \mathrm{M}$ $\mathrm{K}_{2} \mathrm{SO}_{4}$ soil extracts using steam distillation (Bremner and Keeney 1966). Soil pH was measured with a glass-calomel electrode using a soil:water ratio of $1: 2.5$ (weight:volume). Quantification of CEC and exchangeable cations used the procedure of Chapman (1965): $\mathrm{Ca}^{++}$and $\mathrm{Mg}^{++}$ were measured with an atomic absorption spectrophotometer; $\mathrm{K}^{+}$and $\mathrm{Na}^{+}$were measured with a flame photometer.

Soil microbial biomass $\mathrm{C}$ and $\mathrm{N}$ were determined by the chloroform fumigationincubation method (Jenkinson and Powlson 1976). Soil (50 g) was added in each of two, 125-ml Erlenmeyer flasks. Water was added to bring soils to field capacity, and samples were preincubated for 5 days at $25^{\circ} \mathrm{C}$ to stabilize microbial activity. At the end of the preincubation period, 1 of the samples was fumigated with chloroform and the another was left unfumigated. After 24 hours, chloroform was evacuated from the soil samples, and fumigated and unfumigated samples were placed into 1,250-ml glass jars containing a beaker with $15 \mathrm{ml}$ of $0.4 \mathrm{~N} \mathrm{NaOH}$. Jars were closed tightly and incubated for 10 days at $25^{\circ} \mathrm{C}$. Concentration of $\mathrm{CO}_{2}-\mathrm{C}$ 
absorbed by the alkali was determined by titration of excess $0.4 \mathrm{~N} \mathrm{NaOH}$ with $0.1 \mathrm{~N}$ $\mathrm{H}_{2} \mathrm{SO}_{4}$, in presence of $\mathrm{BaCl}_{2}$ (Anderson 1982). Subsequently, mineral $\mathrm{N}\left(\mathrm{NH}_{4}{ }^{+}-\mathrm{N}\right.$ and $\mathrm{NO}_{3}^{-}-\mathrm{N}$ ) in the samples was extracted with $0.5 \mathrm{M} \mathrm{K}_{2} \mathrm{SO}_{4}$ and extracts were analyzed by steam distillation (Bremner and Keeney 1966).

We express microbial biomass $\mathrm{C}$ and $\mathrm{N}$ as the difference in $\mathrm{CO}_{2}-\mathrm{C}$ evolved and $\mathrm{N}$ mineralized between fumigated and unfumigated samples, to avoid the confusion of using different conversion factors $\left(\mathrm{K}_{\mathrm{C}}\right.$ and $\mathrm{K}_{\mathrm{N}}$ ). When comparing with other data, the microbial biomass $\mathrm{C}$ and $\mathrm{N}$ were calculated according to the equation suggested by Voroney and Paul (1984):

Microbial biomass $\mathrm{C}\left(\mathrm{mg} \mathrm{C} \mathrm{kg}^{-1}\right)=$

$\mathrm{Cf}-\mathrm{Cu} / \mathrm{kc}$

where:

$\mathrm{Cf}=\mathrm{CO}_{2}-\mathrm{C}$ evolved from fumigated sample

$\mathrm{Cu}=\mathrm{CO}_{2}-\mathrm{C}$ evolved from unfumigated sample

$\mathrm{K}_{\mathrm{c}}=0.41$ (fraction of microbial biomass converted to $\mathrm{CO}_{2}$ )

Microbial biomass $\mathrm{N}\left(\mathrm{mg} \mathrm{N} \mathrm{kg}^{-1}\right)=$

$\mathrm{Nf}-\mathrm{Nu} / \mathrm{K}_{\mathrm{N}}$

where:

$\mathrm{Nf}=\mathrm{NH}_{4}{ }^{+}-\mathrm{N}$ and $\mathrm{NO}_{3}{ }^{-}-\mathrm{N}$ mineralized from fumigated sample

$\mathrm{Nu}=\mathrm{NH}_{4}{ }^{+}-\mathrm{N}$ and $\mathrm{NO}_{3}{ }^{-}-\mathrm{N}$ mineralized from unfumigated sample

$\mathrm{KN}=(-0.014 \times(\mathrm{Cf} / \mathrm{Nf}))+0.39$

$\mathrm{Cf}=\mathrm{CO}_{2}-\mathrm{C}$ evolved from fumigated sample Indices of mineralizable $\mathrm{C}$ and $\mathrm{N}$ were obtained from unfumigated samples for microbial biomass. They were calculated as the difference of $\mathrm{CO}_{2}-\mathrm{C}$ or inorganic $\mathrm{N}$ concentration before and after incubation, and were expressed as $\mathrm{mg} \mathrm{CO}_{2}-\mathrm{C}$ or $\mathrm{mg}$ inorganic $\mathrm{N}$ per $\mathrm{kg}$ of soil.

Microbial populations were quantified using a dilution pour- plate technique. Bacteria were determined on nutrient agar supplemented with $5 \mathrm{~g} \mathrm{liter}^{-1}$ of glucose (Zuberer 1994), and actinomycetes on casein-starch medium (Kuster and Williams 1964). Petri plates were incubated at $25^{\circ} \mathrm{C}$ for 5 days for bacteria count, and 10 days for actinomycetes count. Total number of bacteria and actinomycetes were expressed as log value of colony forming unit per $\mathrm{g}$ of soil $\left(\mathrm{cfu} \mathrm{g}^{-1}\right)$. Urease activity was measured according to no-buffer method of Douglas and Bremner (1970) and reported as mg N per $\mathrm{kg}$ of soil per hour.

Results are expressed on the basis of dry soil weight. Soil water content was determined gravimetrically by oven drying at $105^{\circ} \mathrm{C}$ for 48 hours.
Table 1. Summary of analysis of variance for microbial biomass carbon (MBC) and nitrogen $(\mathrm{MBN})$, and mineralizable carbon (MC) and nitrogen (MN) at 0-12 cm depth in a grassland soil.

\begin{tabular}{lccccc}
\hline \hline \multirow{2}{*}{ Source of variation } & $\mathrm{df}$ & $\mathrm{MBC}$ & $\mathrm{MBN}$ & $\mathrm{MC}$ & $\mathrm{MN}$ \\
\hline Burning & 1 & $17.11 \mathrm{~ns}$ & $5.99 \mathrm{~ns}$ & $0.02 \mathrm{~ns}$ & $0.25 \mathrm{~ns}$ \\
Block & 1 & $13.26 \mathrm{~ns}$ & $1.79 \mathrm{~ns}$ & $0.37 \mathrm{~ns}$ & $0.36 \mathrm{~ns}$ \\
Date & 3 & $2.64^{*}$ & $1.74 \mathrm{~ns}$ & $16.76^{* * *}$ & $2.32 \mathrm{~ns}$ \\
Burning x block & 1 & $0.03 \mathrm{~ns}$ & $1.21 \mathrm{~ns}$ & $4.16^{*}$ & $2.67 \mathrm{~ns}$ \\
Burning x date & 3 & $0.62 \mathrm{~ns}$ & $0.97 \mathrm{~ns}$ & $1.77 \mathrm{~ns}$ & $0.31 \mathrm{~ns}$ \\
\hline
\end{tabular}

*,*** significant at $\mathrm{P}<0.10$, and $\mathrm{P}<0.0001$, respectively. $\mathrm{ns}=$ not significant.

\section{Statistical analyses}

Data were analyzed using the GLM procedure of SAS (SAS Institute Inc. 1996). In experiment $\mathrm{I}$, content of microbial biomass $\mathrm{C}$ and $\mathrm{N}$, and mineralizable $\mathrm{C}$ and $\mathrm{N}$ on different dates were subjected to an analysis of variance as a split-plot arrangement in a randomized complete block design, with 2 replications. The main plot was the treatment (unburned and burned), and subplot was the sampling date. In experiment II, variables were analyzed according to a randomized complete block design, with 3 replications. Means separation, where necessary, was made by using the least significance difference test (LSD) with 5 or $10 \%$ probability.

\section{Results and Discussion}

\section{Experiment I}

Fire and grazing can influence $\mathrm{N}$ cycling in grassland ecosystems by affecting the spatial distribution of accumulated plant biomass, and $\mathrm{N}$ additions and losses (Hobbs et al. 1991). In this study, there was no effect due to previous grazing on the size of microbial biomass $\mathrm{C}$ and $\mathrm{N}$ (Table 1). The reason is probably because the area was grazed for a relatively short time at a low stocking rate, and both blocks remained closed for 15 months before estimations of microbial biomass. Averaged across all treatments and sampling dates, microbial biomass $\mathrm{C}$ was 421 $\mathrm{mg} \mathrm{CO}_{2}-\mathrm{C} \mathrm{kg}^{-1}$, which is equivalent to $1,027 \mathrm{mg} \mathrm{CO}-\mathrm{C} \mathrm{kg}^{-1}$ according to equation (1). This value is higher than those observed for other grasslands (Fenn et al. 1993, Garcia and Rice 1994). Although microbial $\mathrm{C}$ is a small fraction of the total soil organic $\mathrm{C}$, about $1 \%$ of $67.8 \mathrm{~g} \mathrm{C} \mathrm{kg}^{-1}$, it has a rapid rate of turnover (Jenkinson and Ladd 1981), and represents a substantial pool of soil nutrients. Microbial biomass $\mathrm{C}$ was not affected by burning (Table 1), but tended to be higher in the burned (433 $\mathrm{mg} \mathrm{CO}_{2}-\mathrm{C} \mathrm{kg}^{-1}$ ) than in the unburned treatment $\left(386 \mathrm{mg} \mathrm{CO}-\mathrm{C} \mathrm{kg}^{-1}\right)$ (Fig. 1a) as has been observed in annually- burned tallgrass prairie (García and Rice 1994). Soil microbial biomass $C$ in the top $12 \mathrm{~cm}$ of soil ranged from 277 to $581 \mathrm{mg}$ $\mathrm{CO}_{2}-\mathrm{C} \mathrm{kg}^{-1}$ in the burned treatment and from 170 to $569 \mathrm{mg} \mathrm{CO} 2-\mathrm{C} \mathrm{kg}^{-1}$ in the unburned treatment. This response was a result of the higher temperatures reached by the soil during burning (García 1992), which increased plant residue decomposition rates and the mineralization rates of organic matter (Risser and Parton 1982). Microbial biomass $C$ varied marginally due to sampling date (Table 1), but seasonal dynamics was not significantly affected by burning. The general pattern for microbial biomass $\mathrm{C}$ was to have a decrease at the beginning of plant growth (in early spring, October), a recovery by the end of the growing season (in late summer, March), and was low in winter (August) (Fig. 2a). It was likely that the significant drop in microbial biomass $\mathrm{C}$ in October was due to the reduced availability of organic compounds to soil microorganisms. At the March sampling, microbial biomass $\mathrm{C}$ was significantly higher than it was observed the previous month. As the growing season progressed, the
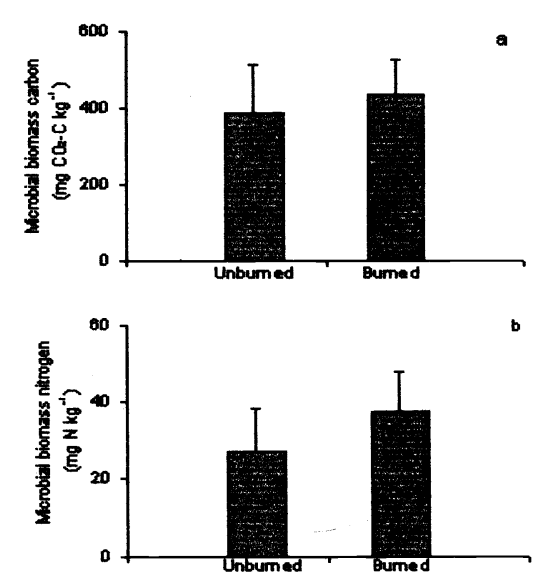

Fig. 1. Content of soil microbial biomass carbon (a) and nitrogen (b) at 0-12 cm depth in unburned and burned grassland soil. Vertical bars represent standard deviations $(n=16)$. 

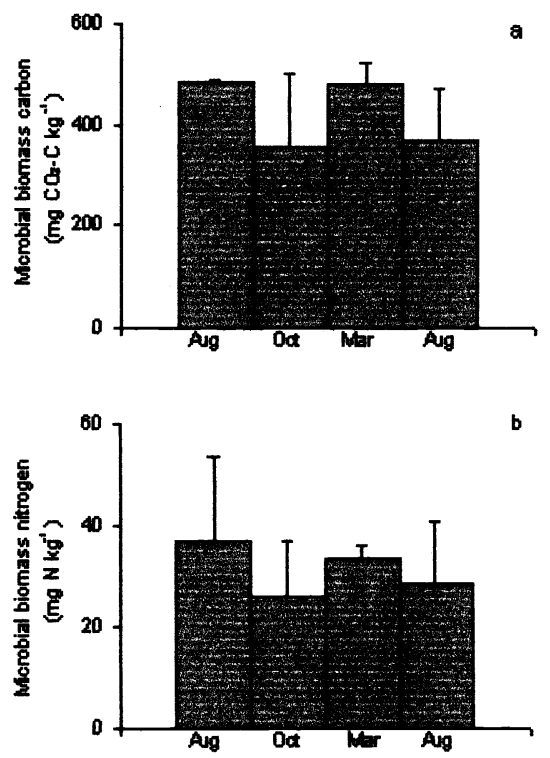

Fig. 2. Seasonal dynamics of soil microbial biomass carbon (a) and nitrogen (b) in a grassland soil at 0-12 cm depth. Vertical bars indicate standard deviations $(n=8)$.

warmer temperatures along with the occurrence of precipitation $(378 \mathrm{~mm}$ from September to March) (Fig. 3) increased root activity and root exudates, which result in increased microbial biomass $\mathrm{C}$ at the end of summer or beginning of fall. Roots are an important source of easily decomposable $\mathrm{C}$ for microbial activity in the perennial grassland, where the majority of plant $\mathrm{C}$ is located belowground (Coleman 1976, Coleman et al. 1983). Lynch and Panting (1980) found that soil microbial biomass increased with root growth and rooting density. Moisture and temperature may also affect the microbial biomass by affecting plant growth and the amount of available substrate for microor- ganisms (García and Rice 1994). Microbial biomass $\mathrm{C}$ was low in soil samples collected in August of the second growing season, when temperature and soil moisture were unfavorable to microbial growth. During winter, temperatures were colder and there were 60 days of drought immediately before sampling (Fig. 3).

Soil microbial biomass $\mathrm{N}$ was $31 \mathrm{mg} \mathrm{N}$ $\mathrm{kg}^{-1}$ for the 0 - to $12-\mathrm{cm}$ depth averaged across all treatments and sampling dates. This value is equivalent to $110 \mathrm{mg} \mathrm{N} \mathrm{kg}^{-1}$ according to equation (2), which is similar or higher than those reported for other grasslands (Fenn et al. 1993, Garcia and Rice 1994). The average C:N ratio of microbial biomass $(9: 1)$ was typical of microbial biomass $\mathrm{C}: \mathrm{N}$ ratios (Paul and Voroney 1980). Soil microbial biomass N was not significantly affected either by burning or sampling date (Table 1). However, it tended to be higher in the burned (37 $\left.\mathrm{mg} \mathrm{N} \mathrm{kg}^{-1}\right)$ than in the unburned treatment $\left(26 \mathrm{mg} \mathrm{N} \mathrm{kg}^{-1}\right)$ (Fig. $1 \mathrm{~b})$, and showed a pattern of seasonal variation similar to that of microbial biomass $\mathrm{C}$ (Fig. 2b). The decline in biomass $\mathrm{N}$ between August and October, assumed to be a result of mineralization, amount to 13 $\mathrm{kg} \mathrm{N} \mathrm{ha}{ }^{-1}$ in the top $12 \mathrm{~cm}$ of soil, therefore a substantial quantity of $\mathrm{N}$ will be available at the beginning of the active plant growth. Clark (1977) indicated that belowground $\mathrm{N}$ translocation may account for $33 \%$ of the aboveground $\mathrm{N}$ requirements in shortgrass prairie, with the remainder provided by mineralization of soil organic $\mathrm{N}$.

Mineralizable $\mathrm{N}$ has been suggested as an index of the soil capacity to supply mineralized $\mathrm{N}$, while mineralizable $\mathrm{C}$ is an index of microbial activity. These pools include the biomass pool and other nonbiomass active fractions of the soil organic matter. It is important to note that these

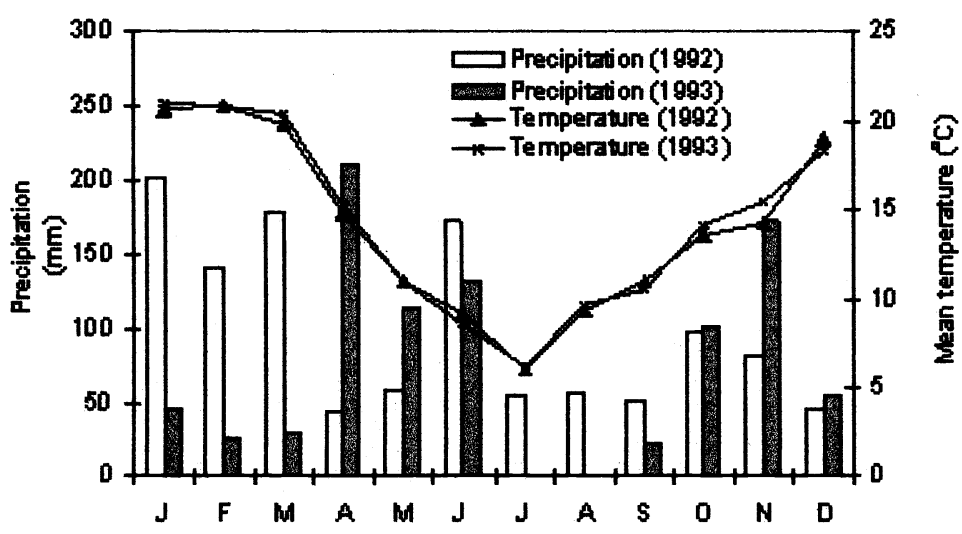

Fig. 3. Weather conditions during the studied period. measurements obtained using the shortterm incubation may not reflect the entire mineralizable organic pools (Cabrera and Kissel 1988).

The size of these pools was not affected by burning, and only mineralizable $\mathrm{C}$ significantly varied with sampling dates (Table 1). Mineralizable $\mathrm{C}$ and $\mathrm{N}$, averaged burned and unburned treatment, was $217 \mathrm{mg} \mathrm{CO}_{2}-\mathrm{C} \mathrm{kg}^{-1}$ and $27 \mathrm{mg} \mathrm{N} \mathrm{kg}^{-1}$ for the 0 - to $12-\mathrm{cm}$ depth, respectively (Fig. $4 \mathrm{a}$ and $4 \mathrm{~b}$ ). In the early spring (October),
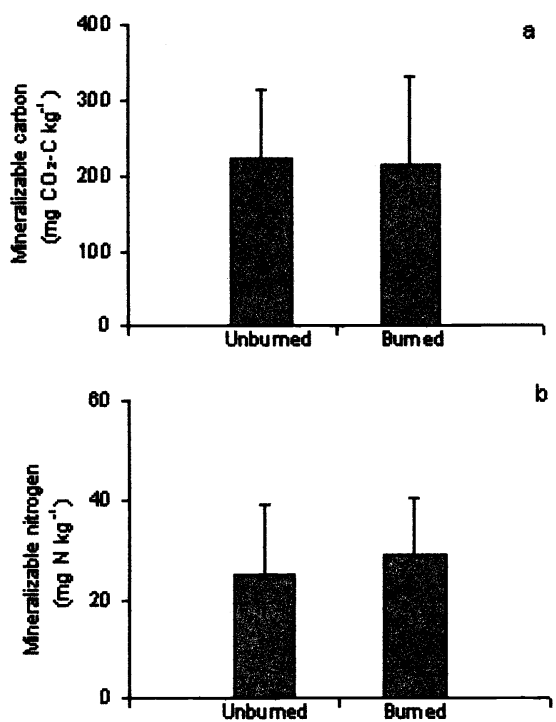

Fig. 4. Mineralizable carbon (a) and nitrogen (b) at 0-12 cm depth in unburned and burned grassland soil. Vertical bars represent standard deviations $(n=16)$.

the grassland soil tended to have a lower production of mineralizable $\mathrm{C}$ but higher inorganic $\mathrm{N}$ content suggesting a lower immobilization of $\mathrm{N}$ into microbial biomass (Fig. 5a and 5b). In fact, microbial biomass showed an important drop at that time. At the end of the growing season (March) occurred the opposite, the grassland soil had higher microbial activity with lower inorganic $\mathrm{N}$ content indicating a higher immobilization, which resulted in more microbial growth and then in microbial biomass (Fig 5a and 5b). Also, at this time the plant uptake of nutrients decreased and $\mathrm{N}$ mineralized is either immobilized by microorganisms or accumulated as inorganic $\mathrm{N}$. Ratio of $\mathrm{CO}_{2}$ evolved : $\mathrm{N}$ mineralized has been suggested as an index of $\mathrm{N}$ immobilization (Schimel 1986). If this ratio is high it means that soil has the ability to immobilize $\mathrm{N}$, but if the ratio is low, the $\mathrm{N}$ mineralization may be high. The calculated ratio 

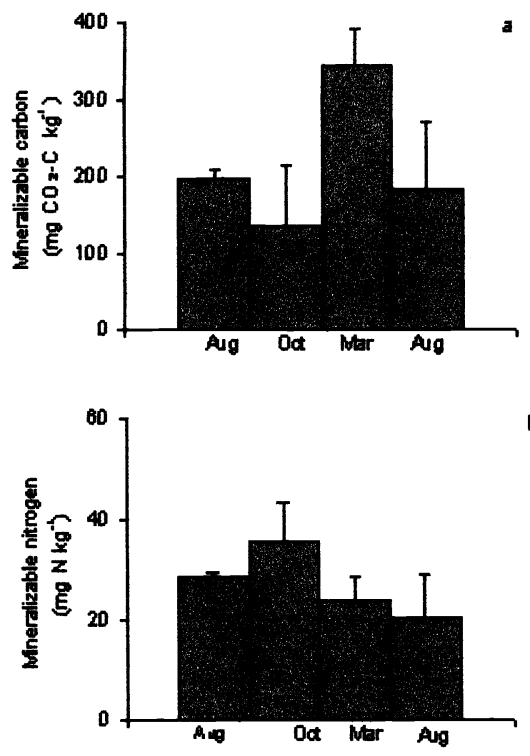

Fig. 5. Temporal dynamics of mineralizable carbon (a) and nitrogen (b) in a grassland soil at 0-12 cm depth. Vertical bars represent standard deviations $(n=8)$.

(data not shown) corroborated the previous observations, and it showed between 3-4 times more microbial activity per unit of mineralizable $\mathrm{N}$ at the initiation of plant growth and 14 more microbial activity per unit of mineralizable $\mathrm{N}$ at the end of the growing season, suggesting higher immobilization at the latter date. The amount and quality of organic substrates available to microorganisms are important controls over the microbial immobilization-mineralization process (Schimel 1986), and may partially explain the changes observed in immobilization-mineralization balance. When the substrate available to microorganisms was the plant tissue with low $\mathrm{C}: \mathrm{N}$ ratio as a grassland regrowth, which was enhanced by moist conditions in early spring, $\mathrm{N}$ immobilization was likely reduced. However, as the easily degradable $\mathrm{C}$ compounds disappeared throughout the growing season, microbial growth and $\mathrm{N}$ immobilization were likely increased. At the sampling of August in the second growing season, microbial activity and biomass were affected not only by the quality of substrate because most of the plant material was senescent, but also by environmental conditions, there was a previous drought, which decreased the pools of $\mathrm{N}$ and $\mathrm{C}$.

In conclusion, in the short term, burning had no significant effect on the size of microbial biomass $\mathrm{C}$ and $\mathrm{N}$ or mineralizable $\mathrm{C}$ and $\mathrm{N}$ in the surface soil of grassland, but microbial biomass tended to be higher in the burned soil. Soil microbial biomass was seasonally dependent, affecting the process of mineralization and immobilization of N. Seasonal changes in microbial biomass, which were not modified by burning, could be related to fluctuations in organic inputs during the growing season, and soil moisture and temperature. The increase in mineralizable $\mathrm{N}$ at the beginning of the growing season matched with less mineralizable $\mathrm{CO}_{2}-\mathrm{C}$ and microbial biomass; whereas the decrease in mineralizable $\mathrm{N}$ coincided with high mineralizable $\mathrm{CO}_{2}-\mathrm{C}$ and microbial biomass at the end of the growing season.

\section{Experiment II}

After field burning it is not possible to separate the effects of heat and ash on several processes in the soil, thus in this experiment we evaluate the potential effect of heat and ash deposition on microbial diversity and some chemical properties, immediately after a single burning.

The immediate effect of fire was to decrease the soil organic $\mathrm{C}$ content in the 0 - to $5 \mathrm{~cm}$ depth. Organic carbon from plant debris, roots, microbial biomass, and organic matter combusted due to the high temperature reached by the soil under fire. The decrease was $11 \%$ (Table 2), however it is likely that $\mathrm{C}$ losses only by heating were even higher in the surface layer because ashes can supply organic matter contributing to mask the differences in organic $\mathrm{C}$ content between burned and unburned treatments. As in the case of soil organic $\mathrm{C}$, organic $\mathrm{N}$ content significantly decreased in the burned soil (Table 2). The the level of total $\mathrm{N}$, when soil and layers of organic residues remain wet less than $25 \%$ of total soil $\mathrm{N}$ is lost (DeBano et al. 1979). In this study, high soil water content (Table 2) could account for the low percentage of $\mathrm{N}$ losses. The $\mathrm{C}: \mathrm{N}$ ratio in the surface of the burned soil $(14: 1)$ was similar to that in the unburned one $(13: 1)$ because the decrease in organic $\mathrm{N}$ was proportional to the loss in organic $\mathrm{C}$. This agrees with that reported by Raison et al. (1985), in that $\mathrm{N}$ compounds are usually lost in direct proportion to the amount of oxidized C.

In spite of the reduction in soil organic $\mathrm{N}$ due to burning, the levels of inorganic $\mathrm{N}$ $\left(\mathrm{NH}_{4}{ }^{+}\right.$and $\left.\mathrm{NO}_{3}\right)$ for plants were almost double in the burned soil (Table 2). The immediate increase in inorganic $\mathrm{N}$ was probably a consequence of physicochemical breakdown of soil organic matter by heat (Biederbeck et al. 1980, Kovacic et al. 1986), since the release of inorganic $N$ through nitrification process requires a period of time elapsed after burning. Ashes can add mineral N, but in small amounts (Raison 1979). The elevated concentration of inorganic $\mathrm{N}$, in unburned soil, indicates that this ecosystems has a considerable potential of $\mathrm{N}$ mineralization.

The level of available $P$ significantly increased from 21.5 to $31.7 \mathrm{mg} \mathrm{kg}^{-1}$, after burning (Table 2). This increase in $\mathrm{P}$ could arise from the release of $\mathrm{P}$ as $\mathrm{H}_{2} \mathrm{PO}_{4}$ - by heating (Fassbender 1975), which formed phosphates of $\mathrm{Ca}, \mathrm{Fe}$, and $\mathrm{Al}$ that are extractable with the technique used for $\mathrm{P}$ determination. Phosphorous may be also added to the soil surface in ashes, mainly

Table 2. Changes in soil nutrient pools and chemical properties at the $0-5 \mathrm{~cm}$ depth in the unburned and burned grassland soil.

\begin{tabular}{|c|c|c|c|}
\hline \multirow[b]{2}{*}{ Soil characteristics } & \multicolumn{2}{|c|}{ Treatment } & \multirow[b]{2}{*}{ Significance } \\
\hline & Unburned & $\overline{\text { Burned }}$ & \\
\hline Water content $\left(\mathrm{g} \mathrm{g}^{-1}\right)$ & 0.48 & 0.46 & ns \\
\hline Organic $\mathrm{C}\left(\mathrm{g} \mathrm{kg}^{-1}\right)$ & 60.65 & 54.10 & ** \\
\hline Organic $\mathrm{N}\left(\mathrm{g} \mathrm{kg}^{-1}\right)$ & 4.37 & 4.07 & $* *$ \\
\hline $\mathrm{NH}_{4}{ }^{+}-\mathrm{N}$ plus $\mathrm{NO}_{3}^{-}-\mathrm{N}\left(\mathrm{mg} \mathrm{kg}^{-1}\right)$ & 39.72 & 69.72 & ** \\
\hline Available $\mathrm{P}\left(\mathrm{mg} \mathrm{kg}^{-1}\right)$ & 21.50 & 31.77 & * \\
\hline $\mathrm{CEC}\left(\mathrm{cmol}_{\mathrm{C}} \mathrm{kg}^{-1}\right)$ & 26.70 & 25.92 & ns \\
\hline $\mathrm{Ca}^{++}\left(\mathrm{cmol}_{\mathrm{c}} \mathrm{kg}^{-1}\right)$ & 12.65 & 12.72 & ns \\
\hline $\mathrm{Mg}^{++}\left(\mathrm{cmol}_{\mathrm{c}} \mathrm{kg}^{-1}\right)$ & 5.28 & 5.53 & ns \\
\hline $\mathrm{K}^{+}\left(\mathrm{cmol}_{\mathrm{c}} \mathrm{kg}^{-1}\right)$ & 1.96 & 2.03 & ns \\
\hline $\mathrm{Na}^{+}\left(\mathrm{cmol}_{\mathrm{c}} \mathrm{kg}^{-1}\right)$ & 0.56 & 1.35 & ns \\
\hline $\mathrm{pH}$ water & 6.85 & 7.23 & $* *$ \\
\hline
\end{tabular}

$*, * *$ significant at $\mathrm{P}<0.1$ and $\mathrm{P}<0.05$, respectively. ns $=$ not significant

organic $\mathrm{N}$ loss, $7 \%$, was probably a result of volatilization of $\mathrm{N}$ compounds during fire (DeBano et al. 1979). Soil moisture content at the time of fire strongly affects

as polyphosphates of $\mathrm{Ca}$ (Raison 1979). The high levels of inorganic $\mathrm{N}$ and available $\mathrm{P}$ may affect the growth of the plant 
Table 3. Enumeration of bacterial and actimomycetes population, and urease activity at the 0-5 cm depth in the unburned and burned grassland soil.

\begin{tabular}{lccc}
\hline \hline & \multicolumn{2}{c}{ Treatment } & \\
\cline { 2 - 4 } Soil characteristics & Unburned & Burned & Significance \\
\hline Bacteria $\left(\log \mathrm{cfu} \mathrm{g}{ }^{-1}\right)$ & 7.31 & 6.93 & $\mathrm{~ns}$ \\
Actinomycetes $\left.(\operatorname{log~cfu~g})^{-1}\right)$ & 5.45 & 5.23 & $\mathrm{~ns}$ \\
Urease activity $\left(\mathrm{mg} \mathrm{N} \mathrm{kg}^{-1} \mathrm{~h}^{-1}\right)$ & 139.9 & 131.2 & $\mathrm{~ns}$ \\
\hline
\end{tabular}

ns = not significant.

community in the first growing season after fire. In fact, aboveground plant production increased following the winter burning of the grassland (Sakalauskas et al. 2001).

The decrease in organic matter content was not reflected in a decrease of CEC, the values of CEC were similar before and after burning (Table 2). Exchangeable $\mathrm{Ca}^{++}, \mathrm{Mg}^{++}, \mathrm{K}^{+}$, and $\mathrm{Na}^{+}$were not affected by burning either (Table 2). In horizons rich in organic matter and with buffer capacity, changes in even the most usually affected properties such as exchangeable cations may not be detectable against natural variation of soil (Raison et at. 1990).

It was observed an immediate and significant increase in $\mathrm{pH}$ after single burning (Table 2). The increase in $\mathrm{pH}$ of 0.38 units compared to unburned soil may be the result of addition of carbonates and oxides of alkali and alkaline earth metals by ashes (Raison et al. 1990) and/ or organic acid losses during the fire (Ulery et al. 1993). The moderate change in $\mathrm{pH}$ was due to the high buffer capacity of this soil (Fabrizzi et al. 1998) and the short time that had elapsed after burning, which may not allow the soil to reach equilibrium $\mathrm{pH}$.

Although burning had no significant effect on numbers of bacteria and actinomycetes in the top $5 \mathrm{~cm}$ of soil (Table 3), trends indicate that burned soil had lower populations of microorganisms. The difference between unburned and burned soil was up to $0.38 \log$ units in the case of bacteria and $0.22 \mathrm{log}$ units for actinomycetes. It appears that the high soil moisture (Table 2) alleviated the effect of burning, because after burning the soil moisture still remained high.

Urease activity was not effected by burning (Table 3), although fire temperature was high enough to denature the enzyme. Tiwari et al. (1988), working with different types of soil, registered urease activity after the soils were ignited at $450^{\circ} \mathrm{C}$. Inorganic catalytic agents are formed in the ignited soil and these are responsible for the hydrolysis of urea. The degree of urea hydrolysis varied with the quality or quantity of the catalytic agents present (Tiwari et al. 1988).
The results indicate that immediately after burning there were losses in total organic $\mathrm{C}$ and $\mathrm{N}$ in the first $5 \mathrm{~cm}$ of soil, presumably because they had been volatilized by the fire; however, substantial amounts of $\mathrm{C}$ and $\mathrm{N}$ were conserved not affecting the quality of soil. Burning was beneficial for plant nutrition because available $\mathrm{N}$ and $\mathrm{P}$ increased, and exchangeable $\mathrm{Ca}^{++}, \mathrm{Mg}^{++}, \mathrm{K}^{+}$, and $\mathrm{Na}^{+}$ were not affected. However, these increases in available $\mathrm{N}$ and $\mathrm{P}$ may be temporary since $\mathrm{N}$ is susceptible to losses and $\mathrm{P}$ reacts with colloids of soil. Burning had no significant effect on numbers of bacteria and actinomycetes, perhaps because of the high soil water content of the soil. Urease activity remained at similar level after burning. Fire provides an alternative to induce immediate changes on the soil; however, long-term studies will be required to evaluate the duration of the effect of fire on soil biological processes and nutrient transformations, and their effects on the ecosystem productivity.

Anderson, J.P.E. 1982. Soil respiration, p 837-871. In: A.L. Page et al. (ed.). Methods of soil analysis. Part 2. $2^{\text {nd }}$ ed Agron. Monogr. 9. ASA and SSSA, Madison, Wisc.

Biederbeck, V.O., C.A. Campbell, K.E. Bowren, M. Schnitzer, and R.N. McIver. 1980. Effect of burning cereal straw on soil properties and grain yields in Saskatchewan. Soil Sci. Soc. Amer. J. 404:103-111.

Bray, R.H., and L.T. Kurtz. 1945. Determination of total, organic and available forms of phosphorus in soils. Soil Sci. 59: $39-46$.

Bremner, J.M. and D.R. Keeney. 1966. Determination and isotope-ratio analysis of different forms of nitrogen in soils: 3 Exchangeable ammonium, nitrate and nitrite by extraction-distillation methods. Soil Sci. Soc. Amer. Proc. 30:577-582.

Bremner, J.M. and C.S. Mulvaney. 1982. Nitrogen-total, p.595-624. In: A. L. Page et al. (ed) Methods of soil analysis. Part 2 Chemical and microbiological properties. 2 nd ed. Agron. 9. ASA and SSSA. Madison, Wisc.

\section{Literature Cited}

Cabrera, M.L. and D.E. Kissel. 1988. Potentially mineralizable nitrogen in disturbed and undisturbed soil samples. Soil Sci. Soc. Amer. J. 52:1010-1015.

Cahuépé, M. A. 1990. Manejo racional de la paja colorada. Revista CREA. Argentina 143:62-69.

Cahuépé, M. A., and P. Laterra. 1998. Manejo de pajonales de paja colorada basado en estudios ecológicos. Estación Experimental Agropecuaria INTA Balcarce. Bol. Tecn. 145.

Chapman, H.D. 1965. Cation-exchange capacity, p. 891-898. In: C. A. Black et al. (ed.). Methods of soil analysis. Part 2. Chemical and microbiological properties. $2^{\text {nd }}$ ed Agron. 9. ASA and SSSA. Madison, Wisc.

Clark, F.E. 1977. Internal cycling of 15 Nitrogen in shortgrass prairie. Ecol. 58: 1322-1333.

Coleman, D.C. 1976. A review of root production processes and their influence on soil biota in terrestrial ecosystems, p. 417-434. In: M. Anderson and A. Macfayden (ed.) The role of terrestrial and aquatic organisms in decomposition processes. Blackwell Scientific, Oxford, England.

Coleman, D.C., C.P.P. Reid, and C.V. Cole.1983. Biological strategies of nutrient cycling in soil systems. Advances in Ecol. Res.. 13: 1-55.

DeBano, L.F., G.E. Eberlein, and P.H. Dunn. 1979. Effects of burning on chaparral soils :I Soil nitrogen. Soil Sci. Soc. Amer. J. 43: 504-509.

Douglas, L.A. and J.M. Bremner. 1970. Extraction and colorimetric determination of urea in soil. Soil Sci. Soc. Amer. Proc. 34:859-862.

Fabrizzi, K., L.I. Picone, A. Berardo, and F. Garcia. 1998. Efecto de la fertilización nitrogenada y fosfatada en las propiedades químicas de un argiudol típico. Ciencia del Suelo 16:71-76.

Fassbender, H.W. 1975. Experimentos de laboratorio para el estudio del efecto del fuego de la quema de restos vegetales sobre las propiedades del suelo. Turrialba 25:249-254.

Fenn, M.E., M.A. Poth, P.H. Dunn, and S.C. Barro. 1993. Microbial N and biomass respiration and $\mathrm{N}$ mineralization in soils beneath two chaparral species along a fire-induced age gradient. Soil Biol. Biochem. 25:457-466.

García, F.O. 1992. Carbon and nitrogen dynamics and microbial ecology in tallgrass prairie. Ph. D. Thesis, Univ. Kansas State. Manhattan, Kans.

García, F.O. and C.W. Rice. 1994. Microbial biomass dynamics in tallgrass prairie. Soil Sci. Soc. Amer. J. 58:816-823.

Hobbs, N.T., D.S. Schimel, C.E. Owensby, and D.S. Ojima. 1991. Fire and grazing in the tallgrass prairie: contingent effects on nitrogen budgets. Ecol. 72: 1374-1382.

Jenkinson, D.S. and J.N. Ladd. 1981. Microbial biomass in soil: measurement and turnover. p. 415-471. In : E.A. Paul and J.N. Ladd (ed.) Soil Biochemistry. Vol 5. Marcel Dekker, New York. 
Jenkinson, D.S. and D.S. Powlson. 1976. The effects of biocidal treatments on metabolism in soil. V. A method for measuring soil biomass. Soil Biol. Biochem. 8:209-213.

Kovacic, D.A., D.M. Swift, J.E. Ellis, and T.E. Hakonson. 1986. Immediate effects of prescribed burning on mineral soil nitrogen in ponderosa pine of New Mexico. Soil Sci. 141:71-76.

Kuster, E. and S.T. Williams. 1964. Selection of media for isolation of streptomycetes. Nature (London). 202:928-929.

Kutiel, P. and Z. Naveh. 1987. The effect of fire on nutrients in a pine forest soil. Plant Soil 104:269-274.

Laterra, P. 1997. Post-burn recovery in the flooding Pampa: Impact of an invasive legume. J. Range Manage. 50:274-277.

Laterra, P., O.R. Vignolio, L.G. Hidalgo, O.N. Fernández, M.A. Cauhépé, and N. O. Maceira 1998. Dinámica de pajonales de paja colorada (Paspalum spp) manejados con fuego y pastoreo en la Pampa Deprimida Argentina. Ecotrópicos. 11:41-149.

Lynch, J.M. and L.M. Panting. 1980. Cultivation and the soil biomass. Soil Biol.Biochem. 12:29-33.

Ojima, D.S. 1987. The short-term and longterm effects of burning on tallgrass prairie ecosystem properties and dynamics. Ph D. Diss., Colorado State Univ., Fort Collins, Colo. (Diss. Abstr. 87-25646)

Paul, E.A., and R.P. Voroney. 1980. Nutrient and energy flows through soil microbial biomass, p. 215-237. In: D. C. Ellwood et al.(ed.) Contem. Micro. Ecol. Academic Press, London.

Raison, R.J. 1979. Modification of the soil environment by vegetation fires, with particular reference to nitrogen transformations: A review. Plant Soil 51:73-108.
Raison, R.J., P.K. Khanna, and P.V. Woods 1985. Mechanisms of element transfer to the atmosphere during vegetation fire. Can. J. For. Res. 15:132-140.

Raison, R. J., H. Keith, and P.K. Khanna. 1990. Effects of fire on the nutrient supplying-capacity of forest soils, p. 39-54. In: W. J. Dyck and C. A. Mees (ed) Impact of intensive harvesting on forest site productivity. Proceedings, IEA/BE A3 Workshop, South Island, New Zealand, March 1989. IEA/BE T6/A6 Report No 2. Forest Res. Inst., Rotorua, New Zealand, FRI Bull. No. 159.

Ricci, L.J., P. Laterra, O.R. Vignolio, and O.N. Fernández. 1996. Dinámicas del banco de semillas de Paspalum quadrifarium Lam. en la Pampa Deprimida, Argentina. Revista de la Facultad de Agronomía, La Plata. 101:25-33.

Risser, P. and W.J. Parton. 1982. Ecological analysis of a tallgrass prairie: Nitrogen cycle. Ecol. 63:1342-1351.

Saá, A., M.C. Trasar-Cepeda, and $T$. Carballas. 1998. Soil P status and phosphomonoesterase activity of recently burnt and unburnt soil following laboratory incubation. Soil Biol. Biochem. 30:419-428.

Sacido, M., L. Hidalgo, and M. Cauhépé. 1995. Efectos del fuego y la defoliación sobre el valor nutritivo de matas de paja colorada (Paspalum quadrifarium). p. 142-146. In: XIV Reunión Latinoamericana de Producción Animal y XIX Congreso de AAPA, Mar del Plata, Buenos Aires, Argentina.

Sakalauskas, K.M., J.L. Costa, P. Laterra, and L. Aguirrezabal. 2001. Effects of burning on soil water content and water use by Paspalum quadrifarium. Agr. Water Manage. 50:97-108.
SAS Institute Inc. 1996. SAS User's guide: Statistics. Version 6.12. SAS Instit. Inc., Cary, N.C.

Schimel, D.S. 1986. Carbon and nitrogen turnover in adjacent grassland and cropland ecosystems. Biogeochem. 2:345-357.

Tiwari, S.C., B.K. Tiwari, and R.R. Mishra. 1988. Enzyme activities in soils: effects of leaching, ignition, autoclaving and fumigation. Soil Biol. Biochem. 20:583-585.

Tomkins, I.B., J.D. Kellas, K.G. Tolhurst, and D.A. Oswin. 1991. Effects of fire intensity on soil chemistry in a Eucalypt forest. Aust. J. Soil Res. 29:25-47.

Ulery, A.E., R.C. Graham, and C. Amrhein. 1993. Wood-ash composition and soil $\mathrm{pH}$ following intense burning. Soil Sci. 156:358-364.

Voroney, R.P. and E.A. Paul. 1984. Determination of $\mathrm{Kc}$ and $\mathrm{Kn}$ in situ for calibration of the chloroform fumigation-incubation method. Soil Biol. Biochem. 16:9-14.

Walkley, A. and I.A. Black. 1934. An examination of Degtjareff method for determining soil organic matter and a proposed modification of the chromic acid titration method. Soil Sci. 37:29-37.

Wright, H. A. and A. W. Bailey. 1982. Fire ecology, United States and Southern Canada. John Wiley and Sons, New York.

Zuberer, D. A. 1994. Recovery and enumeration of viable bacteria. p.119-144. In R.W. Weaver et al. (ed.) Methods of soil analysis. Part 2- Microbiological and biochemistry properties. SSSA Book Series 5, Madison, Wisc. 


\title{
Comment: "Seasonal grazing affects soil physical proper- ties of a montane riparian community." J. Range Manage. 55:49-56
}

\author{
EVERETT M. WHITE
}

Professor Emeritus, Plant Science Dept (Soils), S. D. State Univ., Brookings, S. D. 57007.

Many studies have concluded that soils are compacted by grazing. The amounts of root and organic matter, loss of plant canopy, increased water runoff, and soil erosion also have been sporadically investigated. Soil compaction has been inferred from water infiltration rates and bulk densities. The acceptance of grazing soil compaction seems to have deferred attempts to evaluate other interpretations for changes in bulk densities and water infiltration. Because it has recently been published, an article by a graduate assistant, and three others, will be evaluated as an example.

\section{The study}

Wheeler et al. (2002) studied the impact of a 4- or 5-day intense grazing event on water infiltration and soil bulk densities of a riparian area in the spring and in the summer. Measurements were made immediately before and immediately after grazing and
2 weeks, 4 weeks, and 1 year later. The infiltration rates were compared statistically for grazed and ungrazed paddocks for each measurement date.

Grazed and ungrazed paddocks were statistically different for each grazing period, except after 1 year. When the data were adjusted for the water infiltration difference between grazed and ungrazed paddocks, grazed paddocks had significantly lower infiltration rates. Amounts of clay in the upper $5 \mathrm{~cm}$ of soil, moisture in the 5- to 10-cm layer, and the bulk density of the 5- to 10$\mathrm{cm}$ layer were the best predictors of infiltration but combined only accounted for $23 \%$ of the variation in the data.

\section{Alternate interpretation}

If the infiltration rates of grazed paddocks are plotted against the rates for the ungrazed paddocks (Fig. 1), the rate of change for the ungrazed and grazed paddocks are nearly the same for the

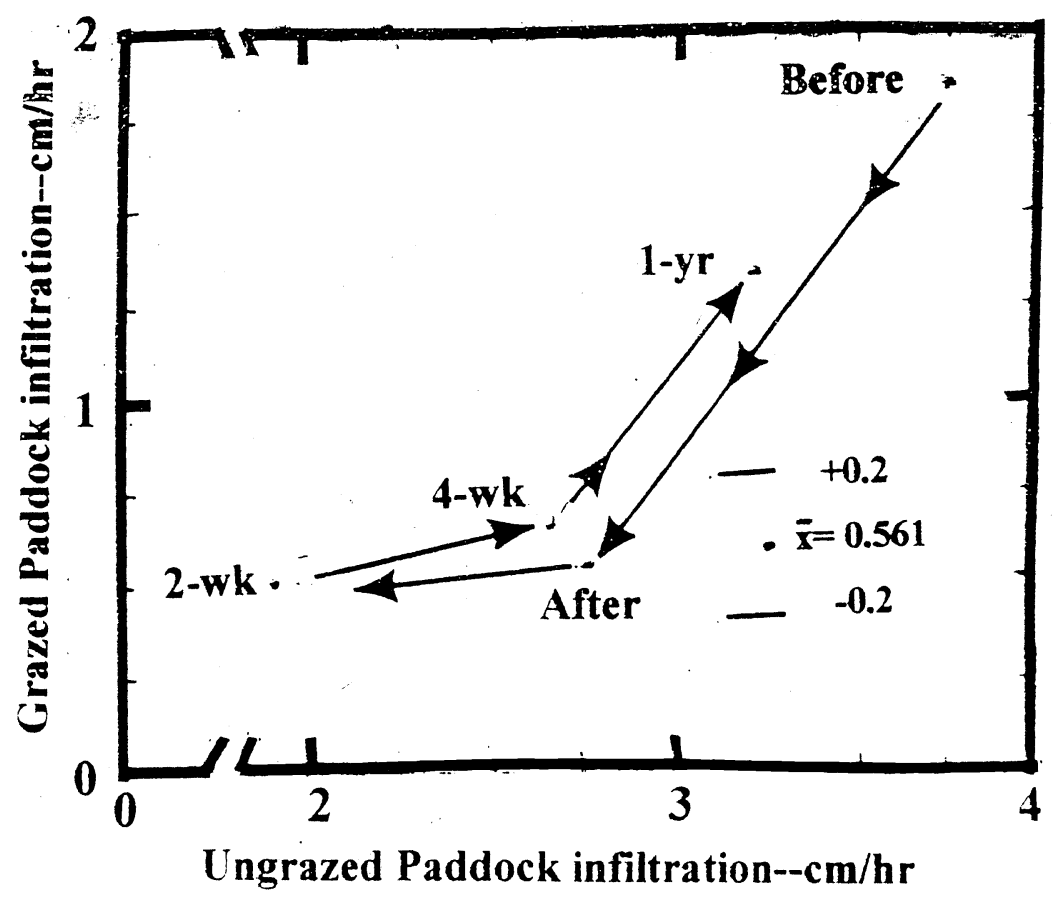

Fig. 1. Water infiltration in grazed- and ungrazed-paddock Before and After grazing and after 2 or 4 weeks, or 1 year. 
two, particularly from Before-grazing to Immediately-after-grazing and from the Four-week to the One-year measurements. The grazed-plot-infiltration rates, ignoring the ungrazed rates, are similar and not significantly different for the After-grazing, Two-week, and Four-week measurements. A conservative estimate of the standard error of the mean was made from Wheeler's Table 1 and is shown on Figure 1 to emphasize these three grazed paddock infiltration rates could be pooled. The rapid changes in the infiltration rates for the ungrazed plots from the After-grazing to Two-week and to Four-week measurements are unusual because no sharp changes were reported for the moisture contents and bulk densities (Figs. 3 and 4). Environmental changes should have the same affect on grazed and ungrazed paddocks. The decreased infiltration for the ungrazed paddocks at the Two-week measurement but not for the grazed paddocks indicates grazing increased infiltration to compensate for the environmentally caused decrease.
Differences in the grazed and ungrazed plots probably are because the ungrazed paddocks were "...within the study area ..." but not necessarily contiguous to the grazed paddocks. The soil survey referenced by Wheeler show a narrow Sheep Creek valley without sufficient width for many contiguous paddocks in one segment of the valley. Thus soil differences and locations in the valley caused most of the differences between grazed- and ungrazedpaddock infiltration rates.

The bulk densities that are reported in Figures 3 and 4 are difficult to interpret because detailed soil descriptions are not included. Descriptions such as "..commonly stratified thin layers of sand or clay." and "...often a highly organic peat layer over $20 \mathrm{~cm}$ thick in sedge riparian areas." are not paddock specific. Some of the 0$15-\mathrm{cm}$ soil should have been in the peat and had a very low bulk density. More likely, soil sample sites were not randomly located. Although the fluvial sediment may have been initially stratified, mixing by plant roots, soil fauna, and freezing and thawing would have destroyed the strata during the time the $20-\mathrm{cm}$ of peat formed. The proportions of sand and clay in the soil affect bulk densities. For example, field-measure and laboratory-measured wet clod and dry clod bulk densities were, respectively, $1.60,1.61$, and $1.72 \mathrm{gm} / \mathrm{cm}^{3}$ for an 8- to 18-inch soil layer with $7.4 \%$ clay and $89.4 \%$ sand and for a $10-18$ inch soil layer with $69.7 \%$ clay and $1.5 \%$ sand, they were, respectively, $1.19,1.03$, and $1.89 \mathrm{gm} / \mathrm{cm}^{3}$ (White, 1967). Moisture contents in the field for the 2 soils were $2.4 \%$ and $23 \%$ respectively. Thus conclusions about bulk density changes caused by grazing cannot be evaluated from the data given.

\section{Literature Cited}

Wheeler, M.A., M.J. Trlica, G.W. Frasier, and J. D. Reeder. 2002. Seasonal grazing affects soil physical properties of a montane riparian community. J. Range Manage. 55:49-56.

White, E.M. 1967. Soil age and texture factors in subsoil structure genesis. Soil Sci.103:288-298. 


\title{
Rebuttal: "Seasonal grazing affects soil physical properties on a montane riparian community" J. Range Manage. 55:49-56
}

\author{
M.A. WHEELER, M.J. TRLICA, G.W. FRASIER, AND J.D.REEDER
}

\author{
Authors are former Graduate Research Assistant and Professor, Rangeland Ecosystem Science, Colorado State University, Fort Collins, Colo. 80523, and \\ Research Scientists, respectively, USDA-ARS, Crops Research Laboratory, 1701 Centre St. , Fort Collins, Colo. 80526
}

We are not certain that we understand all of Dr. E. M. White's concerns on the paper by Wheeler et al. (2002) on "Seasonal grazing affects soils physical properties of a montane riparian community." Dr. White did have some concern about paddock location in a narrow riparian corridor. The 9 paddocks were in fact not contiguous, as he assumed. They were located in the narrow riparian community along the stream course and treatments were randomly assigned to each of the 9 paddocks. Soil and hydrologic data were collected from random locations within each grazing paddock, both before and after grazing events. Certainly there were inherent differences in soils among the paddocks. We anticipated that this was likely, so we utilized 3 replications of paddocks for each treatment to help accommodate the inherent paddock-to-paddock variation encountered. We also sampled soil and hydrologic parameters immediately before grazing of each paddock. These initial data were then used as covariates, or to determine initial differences in inherent paddock-topaddock variations, and to adjust these data collected for each paddock at 4 time periods after the grazing events. We then analyzed changes in soil and hydrologic parameters as affected by grazing treatments. For example, initial infiltration rates were subtracted from subsequent infiltration rates and these resulting data were then analyzed to determine if changes in infiltration rates were significantly affected by seasonal grazing treatments. Changes in infiltration rates could be either positive or negative depending on initial values for infiltration rates. The study design and data collection procedures were discussed with a statistician prior to study initiation and during statistical analyses of these data.

We do not agree with White's statements that "environmental changes should have the same affect on grazed and ungrazed paddocks." Environmental effects could have interacted with grazing treatments to produce some of the results found in this study. We also do not agree with White's statement "the decreased infiltration for the ungrazed paddocks at the two-week measurement but not for the grazed paddocks indicates grazing increased infiltration to compensate for the environmentally caused decrease." Infiltration rates for the grazed paddocks were quite similar immediately after grazing and 2 weeks following grazing (Fig. 2, Wheeler et al. 2002). However, infiltration rates in control paddocks decreased during this same time period. This too might indicate that a treatment by environment interaction did occur.

Soils were variable within this montane riparian community, and fluvial derived stratification in texture was sometimes still apparent. The depth of the peat layer also varied across paddocks, but organic matter content in the $0-5 \mathrm{~cm}$ depth was much greater than at the 5-10 and $10-15 \mathrm{~cm}$ layers. This is probably why soil bulk densities were less in the $0-5 \mathrm{~cm}$ depth and did not show increases after the grazing event as compared with the 2 deeper soil depths. Soils at the 5-10 and 10-15 cm depths did have more mineral matter and did show a significant increase in bulk density after grazing (Fig. 3 and 5, Wheeler et al. 2002). This increase in bulk density at the 2 lower depths probably caused some of the decrease in infiltration rates noted after grazing (Fig. 1, Wheeler et al. 2002). Soil moisture did decline in spring grazed and control plots during the 4 weeks after grazing (Fig. 3, Wheeler et al. 2002), but this was not evident in summer grazed and control plots (Fig. 4, Wheeler et al. 2002).

We therefore can not understand why Dr. White had difficulty in evaluating the results on changes in bulk density as affected by 2 intense seasonal grazing events. If he wishes to utilize all the raw data and do additional analyses, these data are available in the M.S. Thesis by M. A. Wheeler (Wheeler 1998) in the library of Colorado State University. The statistical analyses tables that we utilized in this study are also included in this thesis.

\section{Literature Cited}

Wheeler, M.A. 1998. Seasonal grazing effects on soil physical properties in a montane riparian zone. M. S. Thesis. Colorado State Univ., Fort Collins, Colo.

Wheeler, M.A., M.J. Trlica, G.W. Frasier, and J.D. Reeder. 2002. Seasonal grazing affects soil physical properties of a montane riparian community. J. Range Manage. 55:49-56. 
Resilience and the Behavior of LargeScale Systems. Edited by Lance H. Gunderson and Lowell Pritchard Jr. 2002. Island Press, Washington, DC. 287 p. US $\$ 32.50$ paper. ISBN 1-55963971-7

Ecologists and economists now agree that the traditional term ecosystem is somewhat inappropriate because there are virtually no ecological systems that are utterly devoid of human influence. Consider the case of rangelands. The temporal and the spatial behavior of rangelands is affected not only by a variety of ecological forces but also by human influences. Therefore, such systems verily ought to be viewed and studied as ecological-economic systems that are jointly determined. At the very outset, it is explicitly stated that this edited book's purpose is to discuss "the practical consequences of resilience and its role in sustainability of ecosystems affected by humans" ( $p$. xix). Consequently, even though the book uses the terms ecosystem and large-scale system to refer to its subject matter, it is clear that the use of the newer term ecological-economic system would have been just as apposite. Specifically, the 10 chapters of this book discuss resilience and the use of this notion not only as a heuristic device, but also as a management tool in alternate ecological-economic systems.

Chapters 1 and 2 comprise the first part of this book. Without a doubt, the prose in this part is lucid and the contents of this part are stimulating. It is clearly pointed out that the term resilience has 2 interpretations in ecology. The first interpretation (also known as engineering resilience) is due to Stuart Pimm. This interpretation supposes that ecological-economic systems exist in a stable steady state. Engineering resilience then "is the speed of return to the steady state following a perturbation..." (p. 4). The second interpretation (also known as ecological resilience) is more germane to this book and this interpretation is due to Buzz Holling. Ecological resilience refers to "the magnitude of disturbance that can be absorbed before the system is restructured with different controlling variables and processes" (p. 4). Why is it important to study resilience? The book helpfully explains that the management of most ecological-economic systems is necessarily based on incomplete comprehension. Further, resilient ecological-economic systems are able to effectively withstand management failures stemming from a partial understanding of the underlying system. Consequently, a thorough understanding of the notion of resilience allows individuals-entrusted with the task of managing ecological-economic systemsthe opportunity to learn and adapt.

Chapter 3 delineates the processes that control the resilience of lakes, the pathology of degraded lakes, and the restoration of lakes. We are told that lakes can exist in oligotrophic, dystrophic, and eutrophic states and that, depending on the circumstances, each of these 3 states can be a stable state of existence. Further, rapid transitions between these different states can be caused by perturbations of chemical inputs or food web structure. This chapter concludes with an informed discussion of lake restoration. In this connection, it is rightly noted that the "fundamental problem of lake restoration is an economic mismatch; those who cause the problem do not benefit sufficiently from the remediation. On the other hand, the beneficiaries of lake restoration are not those who caused the degradation" (p. 64).

The Baltic Sea is the topic of Chapter 4. Pointing to the salience of the nutrient load, this chapter discusses the fact that this ecological-economic system can exist in eutrophic and in oligotrophic states. Further, we are told that flips of the system can be of 2 kinds, those that are specific to a particular subsystem and those that involve several subsystems. Even though this is a lengthy chapter, there are some gaps in the discussion. Here are 2 examples. First, the chapter states that the "different structures and time scales of the three subsystems of the Baltic make them examples of different types of resilience..." (p. 93). Is this a claim or a conjecture? If it is a claim then what supporting evidence is there? Further, which interpretation of resilience applies to which subsystem? Second, this chapter points out that because sustainable development is based on the resilience of the total system, "one must ensure that the exploitation of various natural resources is kept within the tolerance limits of the ecosystems" (p. 95). This is a valid but also an obvious point. In this regard, a key question is this: What mechanisms do we need to have in place to ensure that resource exploitation is kept within the tolerance limits? Unfortunately, for both these examples, the kinds of questions I have just listed receive either inadequate or no attention.

Arid and semiarid rangelands constitute the subject matter of the splendid but all too brief Chapter 7. This chapter makes 3 salient points. First, we are told that as in the case of lakes discussed in Chapter 3, rangelands can exist in a normal state in which grasses dominate and a pathological state in which woody plants dominate. Further, state changes "depend on an interaction between an external (rainfall) and an internal driver (stocking rate), but the outcome is largely under the control of the manager" (p. 187). Second, it is noted that most unwanted changes in rangelands arise because of an inadequate understanding of the interactive impacts of the drivers of rangeland dynamics and the fact that "there are threshold effects in these dynamics that result in irreversible or difficult-to-recover-from changes in composition and production" (p. 191). Finally, we are told that virtually all grazed rangelands exist as an unstable mixture of woody plants and grasses. A significant consequence of this fact is that managers "both of livestock and wildlife don't want the rangeland to be at an equilibrium state, even if it were feasible to achieve it" (p. 191).

Let me conclude this review by noting that this book contains a lot of material that is both interesting and thought-provoking. As I have already pointed out, there are a few errors of omission and, on occasion, the book's discussion of economic matters is decidedly sloppy (see $p$. 263). Perhaps the most noteworthy omission is that despite the very basic and fundamental nexus between uncertainty and either notion of resilience, this book has very little to say, in a formal sense, about the apposite way to view, model, and derive measures of resilience in the presence of uncertainty. Even so, I recommend this book to readers not only for what it says about rangelands but also for what it says about other salient ecological-economic systems in different parts of the world.-Amitrajeet A. Batabyal, Rochester Institute of Technology, Rochester, New York. 
Native River. The Columbia Remembered. By William D. Layman. 2002. Washington State University Press, Pullman, Washington. 195 p. US\$24.95 paper. ISBN 0-87422-256-3.

At first glance, this book might seem to be what is known as a coffee-table book. Pick it up and the reader finds out that it is much more. The book can be viewed on 2 levels. On 1 level, one can enjoy the pictures with accompanying explanations. These pictures are fascinating old and new black-and-white photographs the author collected from many sources. On another level, the book can be enjoyed as a historical resource, with the rich detail of thorough research that took many years to accomplish.

William Layman is, as the book cover describes him, a mental health counselor in Wenatchee, Washington. He first saw the Columbia River in 1975 and at that time conceived of writing this book. Since actually starting the book in 1983, Mr. Layman was the recipient of an award given by the Center for Columbia River History (1997), and co-founded the North Central Washington Playback Theatre Company. He calls the book a "book of invitation... [where] readers can enter an earlier world" to view it before it was covered with water.

From its beginnings in Canadian ice fields, the Columbia River travels 1,243 miles to the Pacific Ocean. The book details the portion of the Columbia River that is now known as the Middle Columbia. This section of the river stretches from Priest Rapids north to the United States/Canadian border-a distance of 351 miles. In that distance, the river once dropped more than 945 feet in 1 major waterfall and 50 rapids. Today, only 2 sections of the Middle Columbia still run freely. The first is an 11 mile portion that stretches from the United States/Canadian border to Northport and the second is the Hanford Reach south of Priest Rapids. Few people alive today remember the Columbia River as it flowed before the advent of the first dam (the Rock Island Dam) in 1933. In 1969 and 1974, the Kettle Falls were briefly visible again during reservoir drawdowns. For organizational purposes, Mr. Layman has divided the Middle Columbia River into four parts as follows: Priest Rapids to Rock Island Rapids; Rock Island Rapids to the Okanogan River; Okanogan River to the Spokane River; and Spokane River to the United States/Canadian boundary.

River people, of course, include the Indian tribes that formed intimate relation- ships with the water, land forms, rocks, salmon, sturgeon, and tule. With the dams in place, the Columbia River now covers ancestral lands including village sites, fishing areas, and places of sacred significance. The Columbia River was known as Nch'i.wana in Sahaptin (the language spoken toward the south) and Swah-netk'-qhu in Salish (the language spoken to the north). A common thread throughout the book is the voices of the Indians from their legends, their use of the river before the dams were built, and their present-day perspectives.

All the "players" in the river's history are treated with sensitivity and respect. Besides the Indians who were there before history was written, European-Americans began arriving in increasing numbers after the explorer David Thompson sailed down the river in 1811. Chinese miners later had a significant presence. These people lived along the river, and it to made their lives generally better. Much later, Hispanics and other groups made their homes along or near the river.

The first section describes sites of petroglyph (pictures gouged into rock) images and pictograph (pictures painted on rock) images located along the river. Most of these sites have been destroyed or are now under water. This book serves as a collection of these images in photographs and in drawings of what these artworks looked like before they were submerged. The author uses an intriguing technique of drawing petroglyphs and pictographs as they were found, over diagrams of the old photographs. This technique enables the reader to visualize the artwork on the basalt pillars along the river as it was originally done by the Indian artists.

The book includes hair-raising stories told by white settlers about the difficulties of crossing the river. Drownings and neardrownings were facts of life in the days before the river was dammed.

Most of the stories are told from a European viewpoint, but Mr. Layman includes a few Indian tales that are part of tribal lore and are extremely important in keeping their cultures alive. My favorite is the story concerning the origin of the petrified forest. In this story, as it was told by a Colville Confederated Tribes elder, Coyote was deceived by Raccoon's 7 beautiful daughters. Coyote placed a special curse on the Raccoon family and as a result, all their stored wood was turned to stone, and covered by sand and rock. Coyote also foretold of people coming at sometime in the future and digging up their woodpile. For this reason, we can dig up wood today that is in the form of rock.

Native River is logical in its layout, but without the feeling of there being no surprises. Each page is filled with exciting stories, drawings, or old and new photographs.

In this excellent book, the author achieves what he intended. Mr. Layman takes us on a journey into the past. He is fascinated with the Columbia River and wants readers to share his sense of wonder-an appreciation of a past that can never return, and perhaps a future that values that past. He gives a sense of the Columbia River being a "commons" for all those who are fortunate enough to live within its influence-Lee Walls, Washington State University, Pullman, Washington

\section{Ranching West of the $100^{\text {th }}$ Meridian.}

Culture, Ecology and Economics. Edited By Richard L. Knight, Wendell C. Gilgert, and Ed Marston. 2002. Island Press, Washington, D.C. 259 p. US\$25.00 paper. ISBN 1-55963-827-3.

A thought-provoking anthology of essays and poems about the value of ranching in contemporary society, Ranching West of the $100^{\text {th }}$ Meridian: Culture, Ecology and Economics grapples with some of the toughest questions facing one of America's most beleaguered but enduring occupations. Amidst the dilemmas of skyrocketing land prices, prohibitive estate taxes, quixotic livestock market prices, and increasing public scrutiny, ranchers must balance economics with ecology and public relations with political savvy while simultaneously striving to earn a living and preserve a legacy of open land for family and community. The authors address these topics from a variety of perspectives. They offer insights into the culture, ecology, and economics of ranching, as well as the relevance of ranching to the evolving discussions of ecological sustainability that have begun to dominate the environmental debate. As concerns over global sustainability accelerate, ranching, with its 400-year history of continuous husbandry of land and livestock, emerges as a potential model of both mistakes and successes in the maintenance of unfragmented landscapes and sustainable lifestyles.

Definitions of sustainability are numerous and often conflicting, but all acknowledge the importance of the intergenerational protection and use of land. Most understand the inevitability of accepting less than maximum economic incomes. Ranching families tend to have abundant 
experience with both venues, and hence, as this book's editors conclude, may have much to teach us about how to use the West sustainably. Practitioners of most resource-dependent occupations develop a strong sense of collective identity and a deep sense of pride in their self-sufficiency and independence. Ranchers and other agriculturists who tend their land personally, however, tend additionally to develop an abiding sense of place. This sense, combined with their sense of personal linkage to the land and their willingness to value lifestyle over income, fits them well for expanded roles of stewardship.

Ranching is an intricate mix of romantic myth, harsh physical and economic realities, intimate interaction with the ecology of place, and tightly woven human culture. Understanding the interconnectedness of the diverse elements of this lifestyle, the editors have striven-successfully, I believe-to compile a collection of contributions that addresses ranching holistically rather than reductionally. They speak also to the changes that will be essential if ranching is to remain a strong, socially relevant, and economically viable component of modern society.

The era of a predominantly agricultural West in which ranching went unquestioned as a vital element of a vibrant culture and economy is gone for good. In the early 1900's, agriculturists comprised the vast majority of the American population. In the year 2003 they comprise fewer than 2 percent. Urban and suburban populations are increasingly in contact with and impacted by the effects of land management and livestock management decisions made by ranchers. Ranches and the public grazing permits that are often auxiliary to them have become focal points of public scrutiny as the controversy over appropriate use of public grazing lands has escalated. If ranching is to remain a desired element of Western culture at large, it must be perceived by the public as a crucial and integral part of the sound management of the Western landscape.

The authors examine both the pros and cons of the historical record and current characteristics of ranching. Drawn from what the editors describe as the "radical center," they believe in working to maintain and improve the existing institution of ranching rather than abolishing or overthrowing it. They include academic scholars, ranchers, influential leaders of organizations such as The Nature Conservancy and the American Farmlands Trust, agency representatives from the Natural Resources Conservation Service and the
Bureau of Land Management, freelance writers, and founders of the innovative Malpai Borderlands Group, now recognized as a model example of the movement toward collaborative, cross-boundary land management.

Their diverse viewpoints provide a comprehensive picture of ranching, past, present, and future. They are able to provide insights into both the foundations of present public skepticism regarding the responsibility of ranchers, and the unique benefits in terms of stewardship of open spaces and biodiversity that most ranchers can and do provide society. As ecologists more clearly understand the importance of managing landscapes at large spatial scales, ranches are being viewed as a potent tool in the attempt to maintain privately-owned landscapes in unfragmented condition. Vast areas of open space are essential to the maintenance of the dynamic disturbance and recovery regimes and resulting robust biodiversity that are core elements of healthy ecosystems.. The contributing essayists in Ranching West of the Ranching West of the $100^{\text {th }}$ Meridian: Culture, Ecology, and Economics bring both the ranchers and the public to the figurative table, with insightful analyses of the complicated web of social, biological and economic challenges that ranching must overcome in order to remain viable both as an industry and as a desired component of society. They conclude that ranching, well practiced, strengthens both ecology and community.

What will become of ranches, and of ranchers, now? The answer is, of course, unchanged from any point along the historical continuum of ranching; some will fail, some will be lost to other uses, and some will adapt and succeed. As always, ranching remains an occupation that requires continual reassessment and adjustment of business policies and land stewardship practices. Changing weather patterns, market conditions, ecological disturbance and recovery, emerging scientific understanding, public impressions, and political trends are all variables that require ongoing adjustment of operational strategy. Only those who can effectively incorporate these transitions into their ranch management will prevail.

What lends a new urgency to the question of who and how many will succeed is the rising issue of land scarcity. Formerly, abandoned ranching endeavors most frequently passed into the hands of other ranchers, and the open space of rangeland with all its attendant benefits for ecosystem health and ecological sustainability remained relatively unaltered. Now, however, those who purchase ranches, or parts of ranches, are as likely to be developers or urban-weary residents seeking a suburban slice of a lifestyle with a remnant tang of the freedom of the open range.

Open rangeland is dwindling at an alarming rate, and species diversity and ecological sustainability are suffering in consequence. Those altered acres can no longer serve so effectively as watersheds, biodiversity banks, wildlife habitat, carbon sinks, and sources of the unpolluted skies and open vistas that so many Americans revere. If large ranches are to remain intact, ranchers must remain viable over the long term. To do so, they must reframe their public role and regain their position of cultural desirability. They must improve their understanding and management of ecosystem processes. And they must renew and diversify their economic vigor. The authors of Ranching West of the 100 ${ }^{\text {th }}$ Meridian: Culture, Ecology and Economics conclude that the institution of ranching deserves continued tenure as a desired component of society. Far beyond its traditional role of livestock production, ranching offers a means of protecting open land and biodiversity and directly improving society's likelihood of achieving sustainable ecosystems.

Ranchers are well adapted to the challenge. Most have chosen their lifestyle not because of hope for personal economic gain, but because of a dedication to their land and lifestyle. And that dedication, after all, is the foundation of stewardship. -Roje Gootee, Washington State University, Pullman, Washington. 